\title{
Comitiva de boiadeiros no Pantanal Sul-Mato-Grossense: modo de vida e leitura da paisagem
}

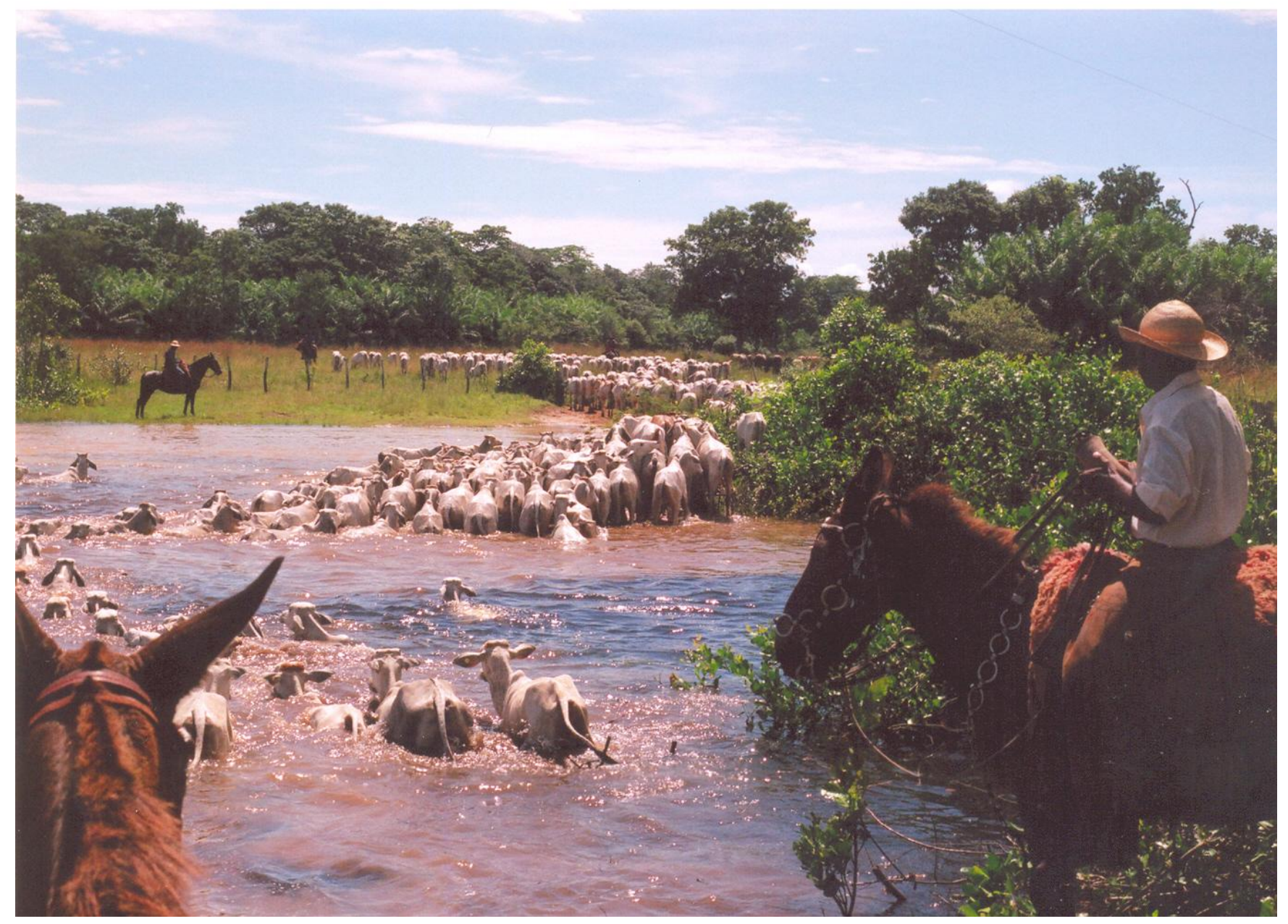

Maria Olivia Ferreira Leite São Paulo, 2010 

COMITIVA DE BOIADEIROS NO PANTANAL SUL-MATO-GROSSENSE: modo de vida e leitura da paisagem

v. 1

Dissertação apresentada ao Programa de PósGraduação em Ciência Ambiental (PROCAM) da Universidade de São Paulo para obtenção do título de Mestre em Ciência Ambiental.

Orientadora: Profa. Dra. Sueli Angelo Furlan 

AUTORIZO A REPRODUÇÃO E DIVULGAÇÃO TOTAL OU PARCIAL DESTE TRABALHO, POR QUALQUER MEIO CONVENCIONAL OU ELETRÔNICO, PARA FINS DE ESTUDO E PESQUISA, DESDE QUE CITADA A FONTE. 



\section{FOLHA DE APROVAÇÃO}

\section{Maria Olivia Ferreira Leite}

Comitiva de boiadeiros no Pantanal Sul-Mato-Grossense: modo de vida e leitura da paisagem.

Dissertação apresentada ao Programa de Pós-Graduação em Ciência Ambiental da Universidade de São Paulo para obtenção do título de Mestre em Ciência Ambiental

Aprovado em:

Banca Examinadora

Prof. Dr.

Instituição: Assinatura:

Prof. Dr.

Instituição: Assinatura:

Prof. Dr.

Instituição: Assinatura: 

Aos boiadeiros do Pantanal, que tanto me inspiraram no trajeto desta pesquisa, por sua beleza, sabedoria e coragem. 



\section{AGRADECIMENTOS}

Esta dissertação não poderia ter sido realizada sem a contribuição dos boiadeiros. Portanto, primeiramente, quero agradecer a todos estes por compartilharem suas histórias e conhecimentos, em especial ao vô Alfredo e Ramon Miranda. Do mesmo modo, foram essenciais as colaborações dos entrevistados Juarez, José Aparecido (Barriga), Sr. Sebastião Rolon e Luís Martins (Biguá). Ao Sr. Oscar (Seu Zé Preto), que sempre foi disposto a colaborar.

À Pousada Xaraés e a Fazenda Nossa Senhora do Carmo pelo apoio durante todo o trajeto desta pesquisa e também, por me possibilitarem participar de uma Comitiva. Ao Hidephotgraphy, especialmente ao fotógrafo Csaba pelas ótimas fotos fornecidas.

Ao casal Dona Edite e Sr. Wilson e à Pousada Caiman, em especial, César e Lousiane, pelo carinho e autorização para o acompanhamento das Comitivas.

Ao Programa de Pós-Graduação em Ciência Ambiental - PROCAM, pela oportunidade do curso de mestrado, especialmente, ao secretário Luciano e Priscila, pelas gentilezas e apoio prestado, que foram além de suas obrigações. Ao Departamento de Geografia pelo solicíto atendimento.

Ao Programa de Apoio à Pós-Graduação - PROAP da Coordenação de Aperfeiçoamento de Pessoal de Nível Superior - Capes, pela concessão de bolsa auxílio para a realização dos trabalhos de campo.

A minha orientadora Profa. Sueli Angelo Furlan, por ter acreditado na minha capacidade e pelas suas fundamentais contribuições. Aos professores Wagner Ribeiro, Prof. Antônio Carlos Diegues, e em especial ao Prof. Euler Sandeville, por compartilharem seu conhecimento e também pelas orientações preciosas ao desenvolvimento deste estudo. 
Aos colegas da USP, especialmente a Juliana Moreno, que se mostrou tão disposta a contribuir com leituras, sugestões, edição e ainda escutar minhas angústias. Ao seu esposo Fábio, por também ter colaborado.

A Profa. Albana Nogueira e ao Prof. Erom Brum por terem me recebido de braços abertos e compartilharem seus conhecimentos sobre a cultura pantaneira.

Ao Schumacher College por conceder-me uma bolsa de estudos integral para o curso "Indigenous peoples \& the natural world: Is ancient wisdom important to the modern world? ”. A participação neste curso não só transformou este trabalho, mas também promoveu uma rica experiência de vida.

À minha mãe Teca, peço desculpas pelas ausências e agradeço por estar sempre ao meu lado. A senhora é um exemplo para mim!

Ao João Simas, pelo companheirismo, paciência, e por tanto me ensinar acerca de sua vivência pantaneira!

Aos meus familiares, que tanto me apoiaram e aconselharam nos momentos mais difíceis, minha irmã Denise, Tia Neidinha, Tia Cida, Tio Zezinho, Tia Maria do Carmo, Telma, Pri, Flavinha. Em especial, aos primos Raquel e Benardo pelas orientações, à Bia, pelo amor com que sempre me hospedou em São Paulo, ainda me ajudando com correções no texto e à Ana Maria pelas correções do resumo em inglês.

Aos amigos que me incentivaram e me aconselharam em diversos momentos, Marcel, Beth, ao casal Patrícia e Arnaud. Ao Thiago e Mari, pelas lindas fotos cedidas.

A Alessandra Fontana, que caminhou comigo durante todo o mestrado, além de contribuir com correções textuais. À sua mãe Vera, que também me hospedou carinhosamente.

Não tenho palavras para agradecer todos vocês, mas os agradecimentos são de coração! 
"Para ser grande, sê inteiro: nada

Teu exagera ou exclui

Sê todo em cada coisa. Põe quanto és

No mínimo que fazes.

Assim em cada lago a lua toda

Brilha, porque alta vive."

Fernando Pessoa. 



\section{RESUMO}

Esta dissertação aborda o modo de vida e a leitura da paisagem dos boiadeiros no Complexo Pantanal Sul-Mato-Grossense. Os boiadeiros representam parte dos trabalhadores da pecuária, uma importante atividade econômica nesta região. Montados em burros, atravessam diversas paisagens viajando até meses, conduzindo grande quantidade de gado pertencente a pecuaristas. Devido à escassez de material disponível na literatura foram coletados relatos, principalmente, de entrevistas com interlocutores locais, suas histórias de vida e através do acompanhamento presencial de Comitivas de boiadeiros. Para compreensão do tema adotouse a concepção de paisagem como lugar no contexto de populações tradicionais, considerando o significado dado pelas experiências vividas e representações simbólicas. A descrição contextualizada de Geertz (1989) trouxe contribuições metodológicas para fundamentar o trabalho de campo e auxiliar na interpretação dos dados. Deste modo, buscou-se esboçar o universo cultural do boiadeiro, descrevendo a estrutura e o cotidiano desta atividade, que segue o ritmo das águas do Pantanal, estabelecendo as fases de enchentes, cheias, vazantes e estiagens. Além disto, por meio de relatos de boiadeiros foram elaborados mapas de alguns dos roteiros destas viagens, identificando-se os marcos referenciais da paisagem cultural e um matiz de linguagens como estratégias de orientação. A interpretação de dados proporcionou uma discussão sobre as contradições e adaptações no modo de vida dos boiadeiros frente às mudanças econômicas e sociais, reconhecendo sua persistência, singularidade e complexidade como um conhecimento extreitamente integrado às paisagens pantaneiras. As reflexões nesta pesquisa pretendem apontar uma diferente perspectiva, de acordo com a importância do valor cultural dos boiadeiros pantaneiros.

Palavras - Chaves: Comitiva de boiadeiros; Pantanal; leitura da paisagem; populações tradicionais; modo de vida. 


\begin{abstract}
This dissertation discusses the way of life and the landscape reading of cattle drovers in the South-Mato-Grosso Pantanal Complex. The drovers represent part of the workforce in the cattle raising, which is an important economic activity in this region. Mounted on donkeys, they cross different landscapes, traveling even for months and driving a large number of herds owned by ranchers. Due to the scarcity of available research material in literature, data was collected mainly from interviews with local counterparts about their life stories and through the monitoring of cattle drovers grouped together. To comprehend the theme, it was adopted the landscape conception as a place in the context of traditional people, taking into consideration the meaning given by life experiences and symbolic representations. The contextual description of Geertz (1989) brought methodological contributions to support the field work and to assist in data interpretation. Thus, we attempted to sketch the cultural universe of the drovers, describing the structure and daily life of this activity, which follows the rhythm of the Pantanal waters, establishing the stages of rising waters, floods, receding waters and droughts. Moreover, maps of some itineraries of these trips were drawn through drovers reports, identifying the landmarks and a tinge of languages as strategic orientation. The data interpretation provided a discussion about the contradictions and changes in the way of life of drovers once facing economic and social changes, recognizing its persistence, uniqueness and complexity as a closely integrated knowledge to the Pantanal landscapes. The reflections in this research intend to target a different perspective, according to the importance of the cultural value of the Pantanal drovers.
\end{abstract}

Key-words: Cattle drovers, Pantanal, reading landscape, traditional people, way of life. 


\section{LISTA DE FIGURAS ${ }^{1}$}

Fig. 1 - Sr. Zé Preto atravessando a boiada no rio Cerradinho. Abobral. Acompanhamento segunda Comitiva.

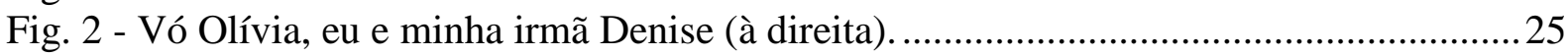

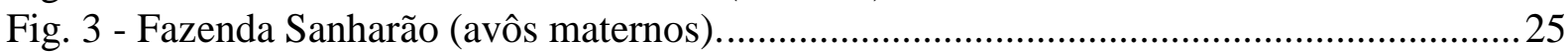

Fig. 4- Vô Basílio, minha irmã Denise e prima Telma (à direita)........................................25

Fig. 5 - Refúgio Ecológico Caiman. Miranda-MS. (Fonte: Refúgio Ecológico Caiman).......27

Fig. 6 - Trabalhando como guia (de costas, explicando sobre a palmeira Acuri): Trilha

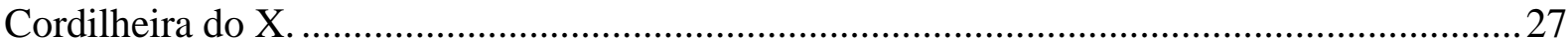

Fig. 7- Trabalhando como guia (em pé, próxima a baía), informando sobre o passeio de canoa.

Fig. 8 - Saída da Comitiva na Fazenda Caiman. Primeiro acompanhamento presencial de uma Comitiva de boiadeiros (ao meu lado direito está o Condutor Sr. Ramon Miranda, logo atrás está o seu pai, Sr. Alfredo, e ao fundo estão os Meeiros, Fiadores e um acompanhador do Retiro Santa Vóia, Fazenda Caiman).

Fig. 9 - Ciclo das águas e boiadeiros no Pantanal-MS. (À esquerda seguindo o sentido da seta: 1. Enchente: Ponte sobre o Rio Miranda. Segunda Comitiva. 2.Cheia: Travessia Rio Cerradinho. Segunda Comitiva. 3. Vazante: Ponteiro Morcego. Primeira Comitiva. 4. Seca: Saída de Comitiva da Fazenda Fátima). Montagem das fotos: Juliana Moreno. ..................... 37 Fig. 10 - Observação participante (primeira comitiva). À minha esquerda, os boiadeiros Vô

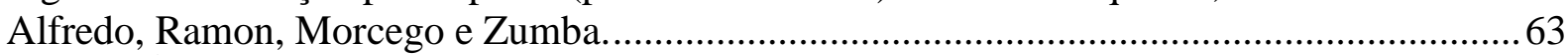
Fig. 11- À minha esquerda, Zumba e à direita Morcego, com berrante. Primeira Comitiva...64

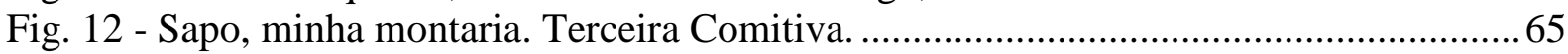

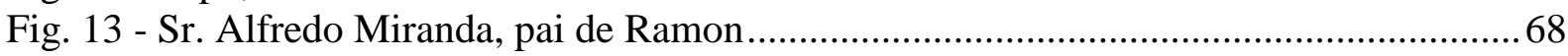

Fig. 14 - Cozinheiro anônimo seguindo viagem. Faz. Nossa Sra do Carmo............................. 68

Fig. 15 - Sr. Zé Preto trabalhando na estação da cheia. Fonte: Pousada Xaraés........................69

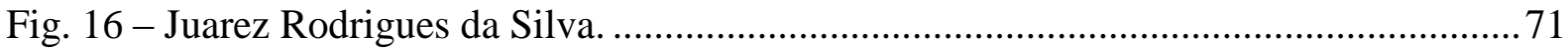

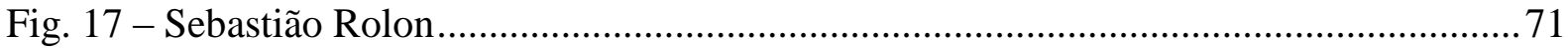

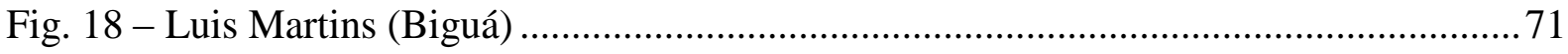

Fig.19-José Aparecido F. da Silva (Barriga). Fonte: Pousada Xaraés. .................................... 71

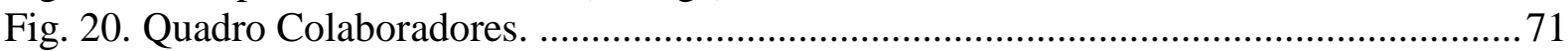

Fig. 21 - Comitiva da Fazenda Redenção no ponto de pouso da Fazenda Nossa Senhora do

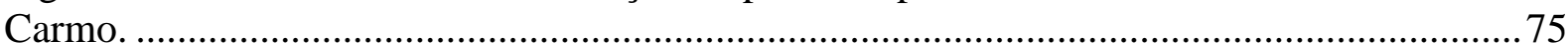

Fig. 22 - Rádio em ponto de parada, na Comitiva da Fazenda Redenção.............................. 83

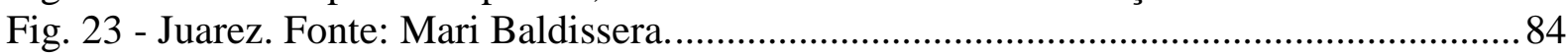

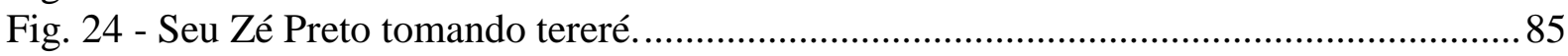

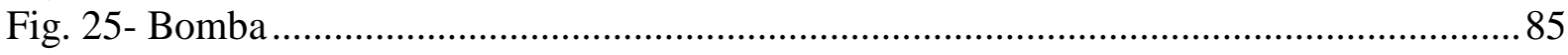

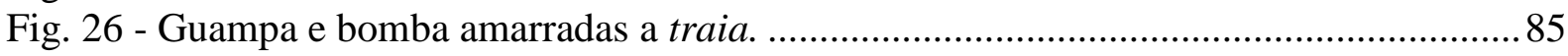

Fig. 27 - Sr. Jair (Beto Carreiro), Wilson e Barba tomando tereré durante a marcha.............. 86

Fig. 28 - Isopor (apelido). Detalhe do chapéu enfeitado com lacres de latas de alumínio.....87 Fig. 29 - Sr. Zé Preto trabalhando com o couro de vaca para uso na própria tralha. Fonte:

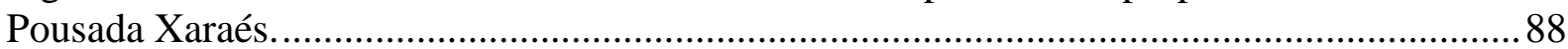

Fig. 30 - Ramon. Detalhe para acessórios. Fonte: Thiago Rocha........................................ 88

Fig. 31 - Boiadeiro anônimo. Ponto de pouso, fazenda Nossa Senhora do Carmo.................. 89

Fig. 32 - Ponteiro Luís com o arreiador, "surrando" o animal. (terceira Comitiva)................. 89

Fig. 33 - Uso do reio por Ramon Miranda. Fonte: Thiago Rocha ......................................... 90

\footnotetext{
${ }^{1}$ As fotos que não possuem fonte são de autoria da pesquisadora.
} 
Fig. 34- Saída da terceira Comitiva. Cozinheiro e tropa cargueira passando à frente da boiada.

Fig. 35- Sr. Geraldo dirigindo trator até o local de saída da primeira Comitiva acompanhada.

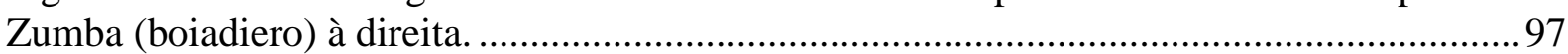

Fig. 36 - Simulação das funções dos boiadeiros em Comitiva............................................ 102

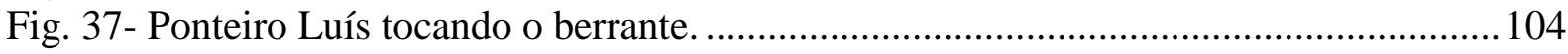

Fig. 38. Ponteiro Morcego na Comitiva Fazenda Caiman ( 2005). Fonte: Thiago Rocha..... 104

Fig. 39 - Contagem de bois pelo Condutor. Terceira Comitiva........................................... 106

Fig. 40 - Acompanhador de fazenda e Cozinheiro Dourado. ................................................ 109

Fig. 41 - Cozinheiro Dourado encilhando burro cargueiro (bruacas em baixo, dobros

dispostos sobre a mesma e lona para cobri-los). ............................................................ 110

Fig. 42- Burro cargueiro encilhado. Comitiva Caiman. Fonte: Thiago Rocha...................... 110

Fig. 43- Mula cargueira encilhada. Comitiva Caiman. Fonte: Thiago Rocha........................ 110

Fig. 44 - Ponto de pouso Fazenda Buriti. Terceira Comitiva. ............................................. 110

Fig. 45 - Ponto de pouso. Redes armadas. Fonte: Csaba Gődény. ..........................................111

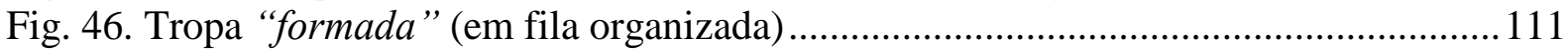

Fig. 47 - Marcas dos boiadeiros em ponto de parada (cinzas e postes para redes)................112

Fig. 48 - Cozinheiro e sua cozinha. Fonte: Csaba Gődény ................................................... 112

Fig. 49. Organização da cozinha. Pesquisadora e Ramon Miranda. ....................................... 114

Fig. 50 - Cozinheiro Gilberto preparando arroz carreteiro. Comitiva Caima. Fonte: Thiago

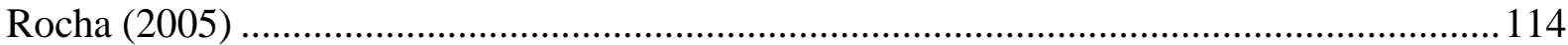

Fig. 51 - Cozinheiro Gilberto preparando almoço. Comitiva Caiman. Fonte: Thiago Rocha

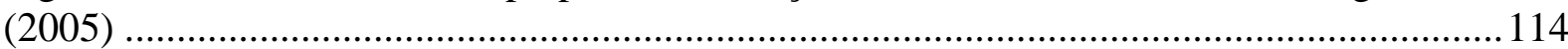

Fig. 52- Organização da cozinha. Panelas de comida sobre trempe e o fogo. Outros utensílios

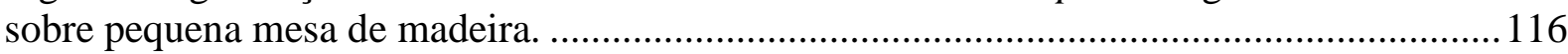

Fig. 53 - Bule de café e coador. Panela com água fervida, colher de concha e canecas de café.

Fig.54- Latas d' água penduradas em figueira (Fícus sp), colheres de concha, caneca maior

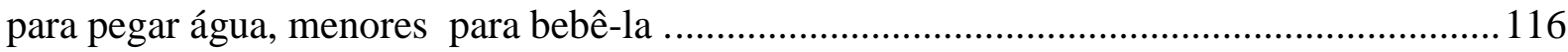

Fig. 55 - Poeira no estradão: terceira Comitiva. .................................................................. 120

Fig. 56 - Estouro de boiada na travessia do Rio Abobral. Comitiva da Nossa Senhora de

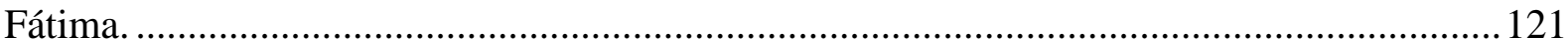

Fig. 57 Amanhecer no ponto de pouso da fazenda Nossa Senhora do Carmo. Comitiva

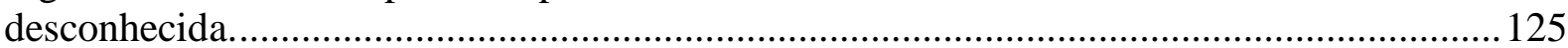

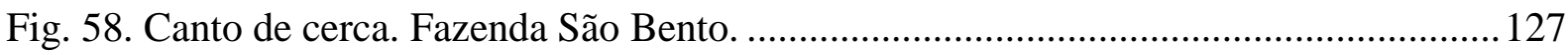

Fig. 59 - Porteira de varas. Fazenda Nossa Senhora do Carmo. ........................................... 128

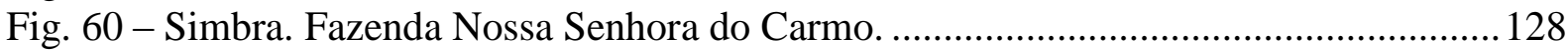

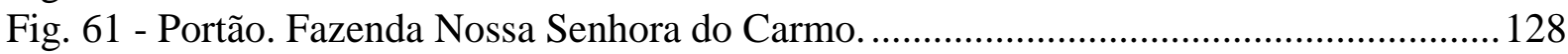

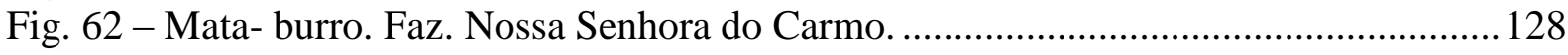

Fig. 63 - Cocho. Faz. Nossa Senhora do Carmo................................................................ 128

Fig. 64 - Ponte sobre o Rio Abobral. Segunda Comitiva. Pousada Xaraés. ........................... 129

Fig. 65 - Comitiva Caiman. Fonte: Thiago Rocha............................................................... 129

Fig. 66. Poço na invernada Antena. Faz. Nossa Senhora do Carmo. Terceira Comitiva....... 129

Fig. 67 - Corredor Faz. São Bento. Região Abobral........................................................... 130

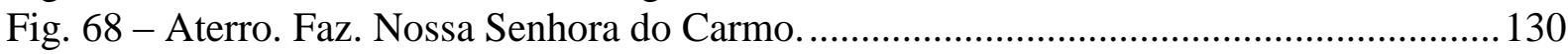

Fig. 69 - Boiadeira Central. Faz. São Carlos (seta branca indica estrada)............................ 130

Fig. 70 - Estrada d'água. Faz. Nossa Senhora do Carmo. .................................................... 131

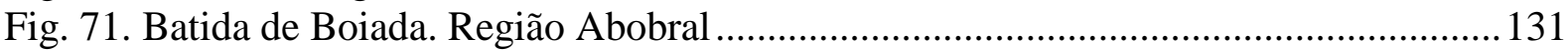

Fig. 72 - Estrada de cascalho. Região Nabileque................................................................ 131

Fig. 73. Magro (apelido) na Comitiva da Fazenda Caiman. Fonte: Thiago Rocha................. 132 


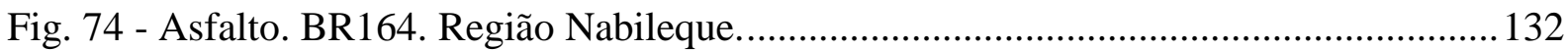

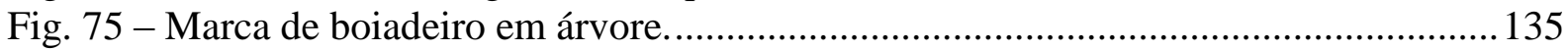

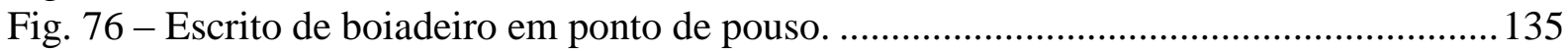

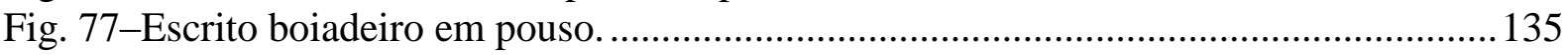

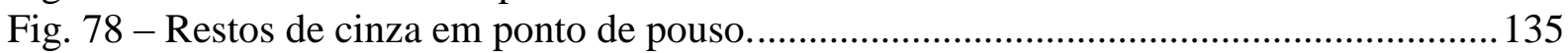

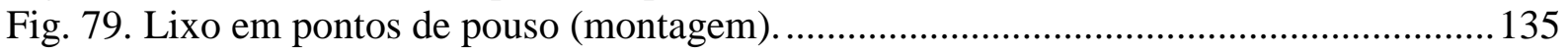

Fig. 80 - Rabo de burro (A. bicornis). Região Abobral. .................................................... 137

Fig. 81 - Pasto formado com humidícula. Região do abobral. ............................................ 137

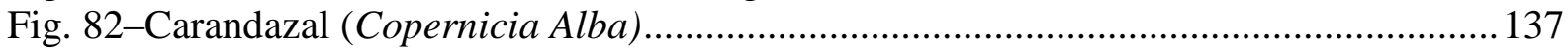

Fig. 83 - Estrada com mato fechado. Primeira Comitiva. Região Aquidauana/ ..................... 137

Fig. 84 - Campina. Faz. Nossa Senhora do Carmo.............................................................. 138

Fig. 86 - Cordilheira. Faz. Nossa Senhora do Carmo.......................................................... 138

Fig. 87 - Capão. Refúgio Ecológico Caiman ...................................................................... 138

Fig. 88 - Raque e pecíolo de Acuri como espeto de churrasco..........................................138

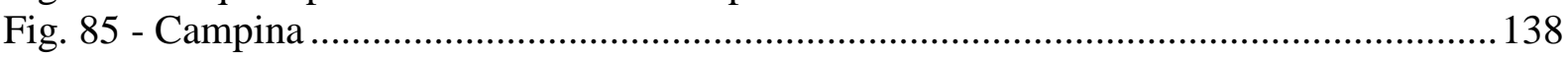

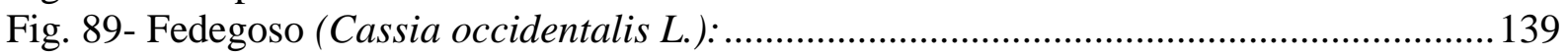

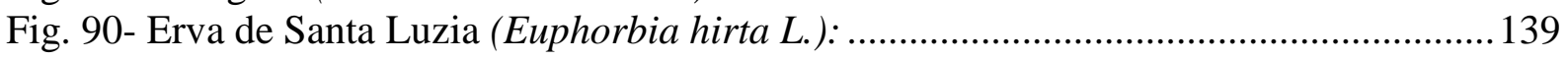

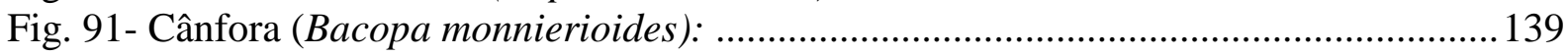

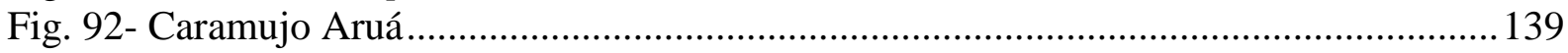

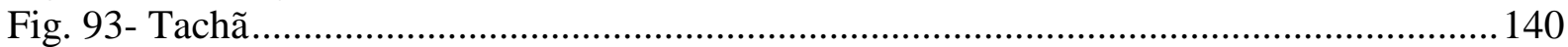

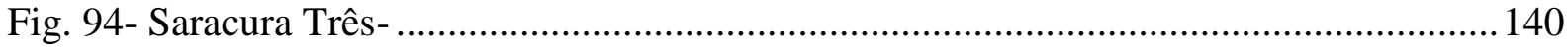

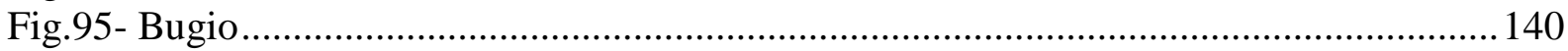

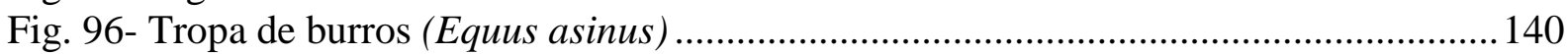

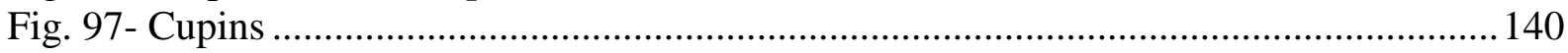

Fig. 98 - Areião. Retiro Santo Onofre. Faz. Santa Filomena............................................... 142

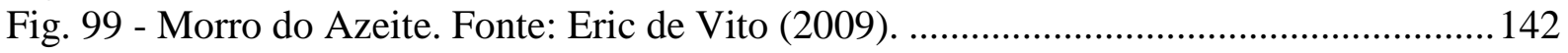

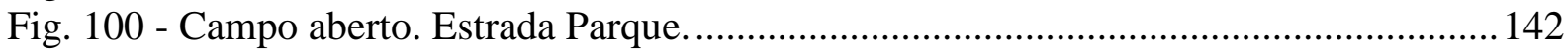

Fig. 101 - Bola pé. Travessia boiada no rio Cerradinho. Segunda Comitiva. Fazenda Fátima.

Fig 102 - Vazante Cerradinho. Faz. Nossa Senhora do Carmo...

Fig. 103 - Rio Paraguai. Porto da Manga. Embarcadouro de gado. ......................................... 146

Fig. 104 - Corixo do inferno. Faz. Nossa Senhora do Carmo. .............................................. 146

Fig. 105. Marcos Antonio Vaca (Babuíno). Segunda Comitva. Carandazal........................... 153

Fig. 106 - Orelhas do Sapo. Fazenda Santa Filomena. Segunda Comitiva. ........................... 166 


\section{MAPAS}

Mapa 1 - Sub- Regiões ou "pantanais" do Pantanal: Bacia do Alto Paraguai no Brasil. Fonte: Silva; Abdon (1998).

Mapa 2- Mapa ilustrativo: Fazendas Pantanal- MS e roteiros das três Comitivas acompanhadas. Fonte: EMBRAPA (modificado). 66 Mapa 3 - Mapa falado por Biguá (2009) do roteiro de Comitiva de Aquidauana a Fazenda Central. 


\section{TABELAS}

Tabela 1 - Acompanhamento de Comitivas 65

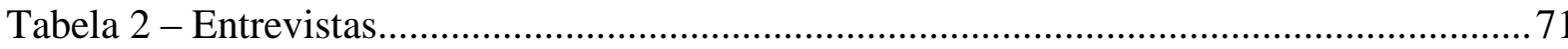

Tabela 3 - Simulação de custos para o comprador de gado na contratação do serviço de uma Comitiva com duração de 11 marchas.

Tabela 4 - Simulação de custos do Condutor pela prestação do serviço de uma Comitiva de 11 marchas

Tabela 5 - Marcos referenciais da paisagem: paisagens da fazenda.................................. 127

Tabela 6 - Marcos referenciais na leitura da paisagem: marcas e escritos de boiadeiros....... 135

Tabela 7 - Marcos referenciais na leitura da paisagem: vegetação...................................... 137

Tabela 8 - Exemplos de plantas medicinais e formas de utilização citadas pelos boiadeiros.

Tabela 9 - Marcos Referenciais na leitura da paisagem: exemplos de animais....................139

Tabela 10 - Marcos referenciais na leitura da paisagem: solos e relevo................................ 142

Tabela 11 - Marcos referenciais na leitura da paisagem: paisagens aquáticas ....................... 146

Tabela 12 - Diferenças entre o ciclo das águas (cheia e seca) e seus significados para boiadeiros 


\section{SUMÁRIO}

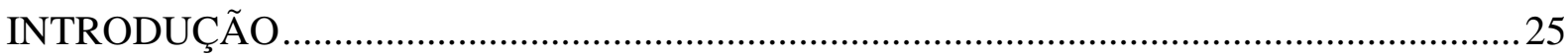

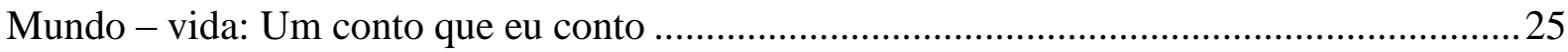

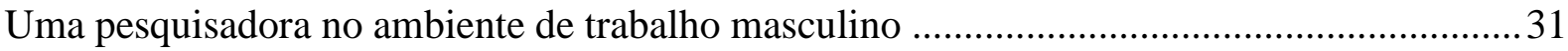

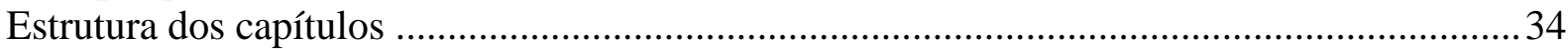

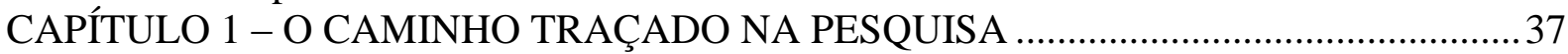

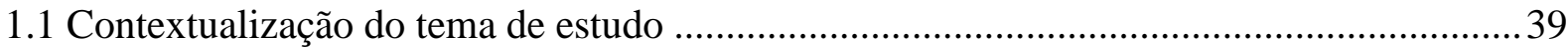

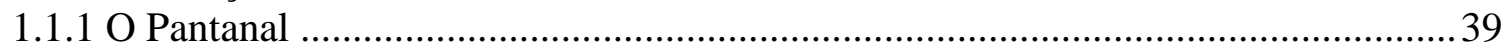

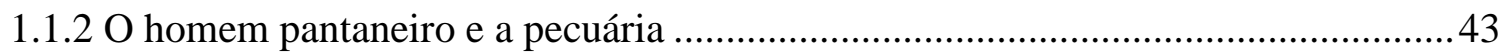

1.2 Marco conceitual: A interpretação da paisagem como lugar no contexto de populações tradicionais

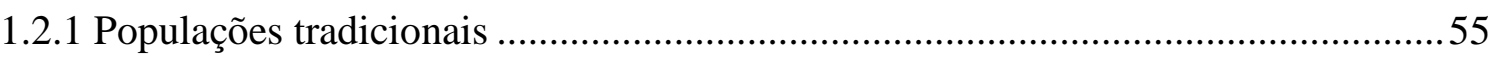

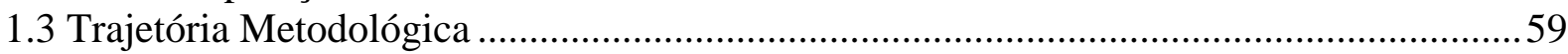

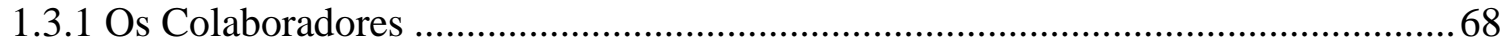

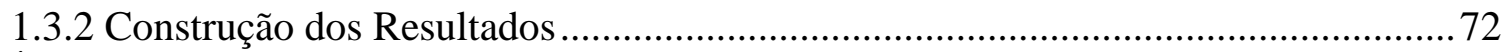

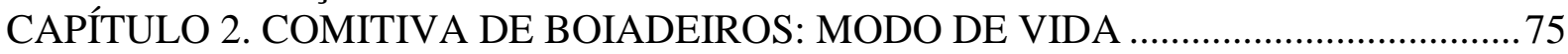

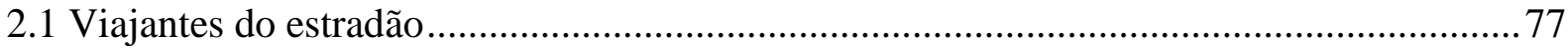

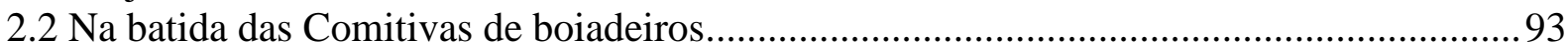

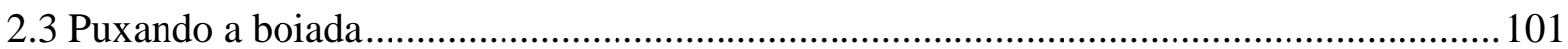

CAPÍTULO 3 - COMITIVA PANTANEIRA: LEITURAS DAS PAISAGENS .................. 121

3.1 Na batida do Estradão - marcos referenciais na paisagem ............................................. 124

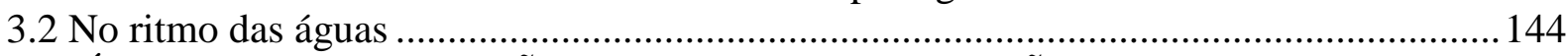

CAPÍTULO 4: APROXIMAÇÕES PARA UMA CONCLUSÃO ..................................... 153

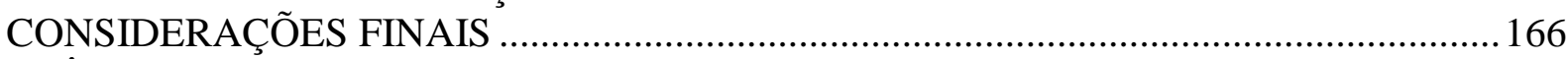

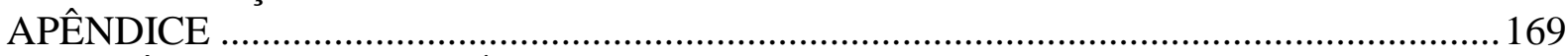

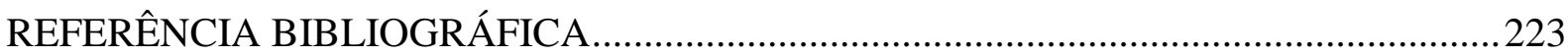




\section{INTRODUÇÃO}

\section{Mundo - vida: Um conto que eu conto}

Faz-se necessário, como parte da trajetória metodológica ${ }^{2}$ escolhida para esta pesquisa, discorrer sobre as razões pessoais que motivaram este trabalho. Expor um pouco da minha história de vida através de memórias, imaginação, percepções e antecipações.

Talvez a inspiração para esta pesquisa tenha se iniciado quando pequena no convívio com minha família materna, em uma fazenda na região do Vale do Ribeira, Mata Atlântica, no município de Barra do Turvo, São Paulo (Fig.2, 3 e 4). Meus avôs eram produtores rurais, meu avô, mesmo analfabeto, negociava e viajava transportando gado e conduzindo porcos a pé. Coisas vividas que contadas nos caminhos da pesquisa renderam boas risadas com alguns

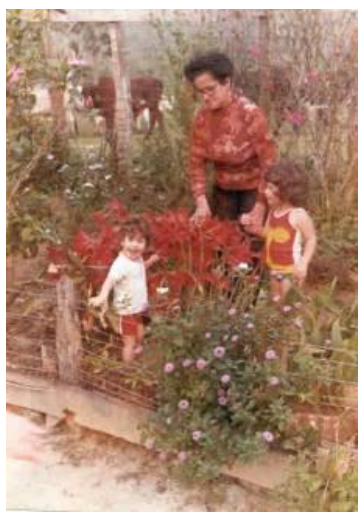

Fig. 2 - Vó Olívia, eu e minha irmã Denise (à direita).

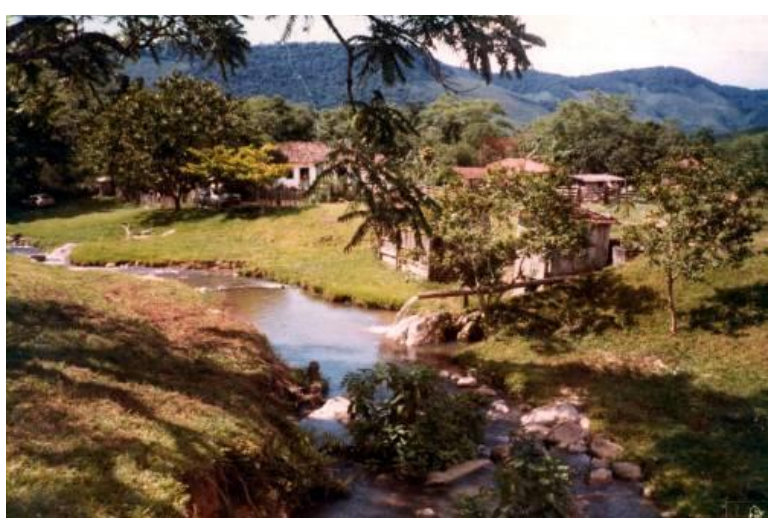

Fig. 3 - Fazenda Sanharão (avôs maternos).

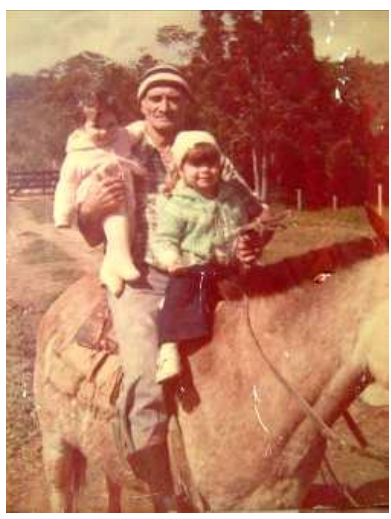

Fig. 4- Vô Basílio, minha irmã Denise e prima Telma (à direita).

boiadeiros, pois no Pantanal são acostumados apenas a conduzir gado a cavalo. Tocar porco a pé soa muito esquisito! Foram anos marcantes de minha vida, dos quais guardo lembranças e

\footnotetext{
${ }^{2}$ Ver mais em no item 1. 3, p. 59
} 
ouço histórias contadas e re-contadas na família que aguçam minha curiosidade até os dias de hoje sobre o modo de viver, sentir e trabalhar na pecuária e agricultura.

Dessas vivências, credito o surgimento do interesse pelo modo de vida rural e o interesse pela pesquisa da vida da gente do campo. Um pouco difícil, porém, tem sido relacionar emoção e razão ou coração e cientificidade. Desenvolver o mestrado para mim foi algo quase que visceral e apesar de haver tantas regras formais nessa trajetória, ainda acredito que não é necessário se perder a paixão. De qualquer forma, compreendo que há muita responsabilidade em escrever sobre outros modos de vida, outras visões de mundo, que são diferentes de minha experiência, portanto o cuidado científico proporcionou uma segurança necessária durante a elaboração deste trajeto acadêmico.

Este estudo é a continuidade de uma experiência de pesquisa que realizei na monografia de conclusão da graduação em Ecologia na Universidade Estadual de São Paulo (UNESP- Rio Claro) em $2002^{3}$. Naquele momento, buscava compreender a relação entre homem e ambiente por meio do espaço vivido por moradores limítrofes às áreas naturais protegidas na região do Vale do Ribeira, no mesmo município onde residiam meus avôs maternos. Meu interesse foi buscar compreender como viviam populações estreitamente dependentes dos ritmos da natureza, quais saberes ou conhecimentos emergiam dessa relação e como têm se mantido diante da realidade atual.

Após esta experiência com a pesquisa acadêmica vivi uma curta experiência trabalhando em São Paulo, quando surgiu uma oportunidade para trabalhar como guia de ecoturismo em uma pousada no Pantanal (Refúgio Ecológico Caiman- Fig. 5, 6 e 7). A entrevista foi feita em São Paulo e acho que fiquei o tempo todo olhando e refletindo, de certo modo encantada com um quadro que mostrava a fotografia da pousada à beira de uma baía imensa. Fui ao encontro

\footnotetext{
3 LEITE, Maria Olivia Ferreira. "Homem e ambiente: Um estudo sobre a compreensão de moradores do Vale do Ribeira-SP”. Trabalho de Conclusão de Curso, UNESP, Instituto de Biociências, Rio Claro: maio, 2002.
} 
da paisagem do quadro... Assim, pude apaixonar-me pelo Pantanal e aos poucos, aproximarme do ritmo da região, das estações e da cultura pantaneira.

Foi desta convivência que surgiu a chance, em 2005, de acompanhar uma Comitiva de boiadeiros (Fig. 8), onde o intuito era o de transportar cerca de 500 vacas da Fazenda Estância Caiman para outra fazenda, do mesmo proprietário ${ }^{4}$.
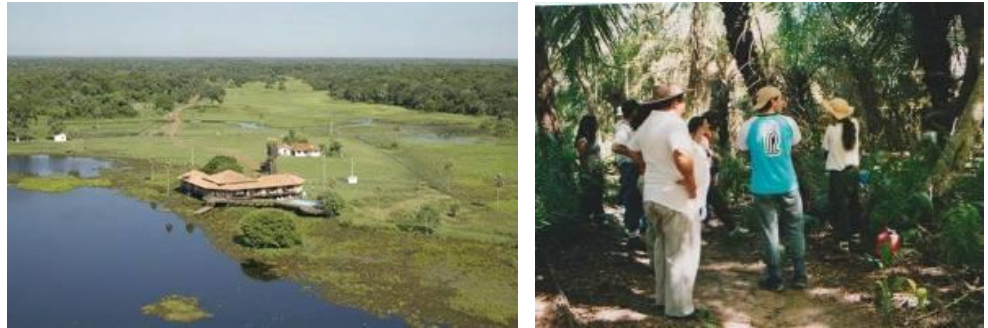

Fig. 5 - Refúgio Ecológico Fig. 6 - Trabalhando como Caiman. Miranda-MS. (Fonte: guia (de costas, explicando Refúgio Ecológico Caiman). sobre a palmeira Acuri): Trilha Cordilheira do X.

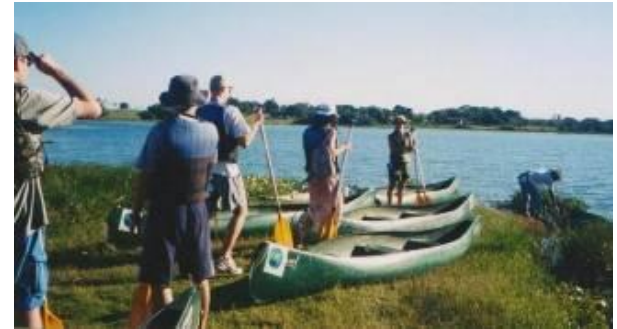

Fig. 7- Trabalhando como guia (em pé, próxima a baía), informando sobre o passeio de canoa.

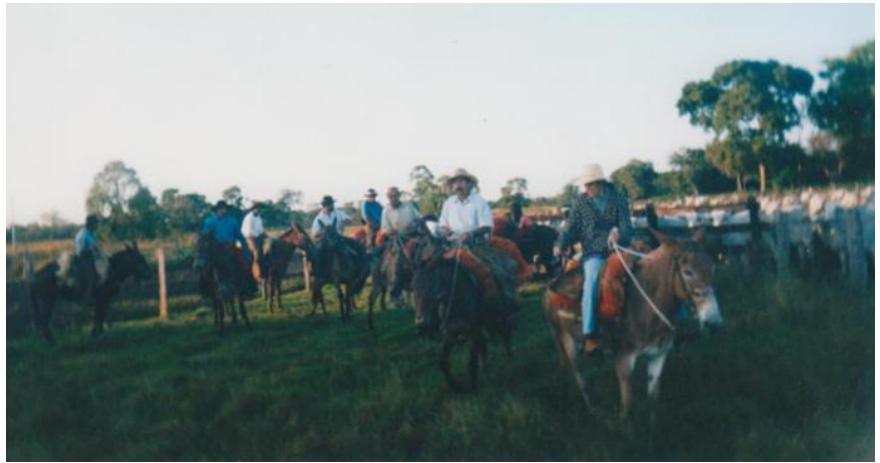

Fig. 8 - Saída da Comitiva na Fazenda Caiman. Primeiro acompanhamento presencial de uma Comitiva de boiadeiros (ao meu lado direito está o Condutor Sr. Ramon Miranda, logo atrás está o seu pai, Sr. Alfredo, e ao fundo estão os Meeiros, Fiadores e um acompanhador do Retiro Santa Vóia, Fazenda Caiman).
Acompanhei esta viagem durante quatro dias e quando retornei acabei escrevendo um pouco sobre minha experiência ${ }^{5}$, mais como uma primeira reflexão que queria partilhar.
Naquele momento não havia intenções conceituais de pesquisa acadêmica, porém, pouco tempo depois, conversando com uns amigos sobre meu entusiasmo com o trabalho das Comitivas, trouxeram-me uma reportagem, capa da revista Terra. O título dizia: "Pantaneiro, um ser em extinção" (FRUET, 2004). O senhor que aparecia na capa era o pai da pessoa que me mostrava. O que me chamou a atenção foi que, na mesma época, em outra revista, li o comentário de pesquisador do Grupo de Estudos de Agronegócios da UFMS (Universidade

\footnotetext{
${ }^{4}$ Apesar de esta oportunidade ter surgido através do trabalho como guia de ecoturismo, a Comitiva acompanhada não possuía qualquer fim turístico.

${ }^{5}$ Ver Apêndice A.
} 
Federal do Mato Grosso do Sul) afirmando que "Não há dados disponíveis, mas as comitivas de boiadeiros estão diminuindo e, no futuro, deixarão de existir”. (BRUM, 1998).

Daí em diante foram mais e mais investigações, sempre constatando a falta de dados sobre os boiadeiros, principalmente, no que se refere às publicações científicas. E não obstante seja possível encontrar pesquisas sobre modos de vida de peões de fazenda pantaneiros, com similaridades ao modo de vida dos boiadeiros, estes executam outros trabalhos e possuem costumes diferentes ${ }^{6}$.

Como o boiadeiro costuma trabalhar informalmente (sem contrato de trabalho ou registro em carteira) e as Comitivas são itinerantes, é difícil obter dados estatísticos sobre sua ocorrência e, além disto, não costumam ser foco das problemáticas debatidas. Aparecem envolvidos em uma conjuntura econômica centralizada na discussão sobre o desenvolvimento da pecuária.

Em uma pesquisa historiográfica, onde foram analisadas as Comitivas de boiadeiros no Pantanal afirmou-se que, embora os boiadeiros ocupassem - e ainda ocupam - papel destacável na introdução e expansão da pecuária, sua presença na história é precariamente tratada, as informações são esparsas e pouco expressivas. O autor expõe, retoricamente, que apesar de ser tema recorrente entre poesias e músicas, é de forma indireta que a maior parte da bibliografia se apresenta: é comum encontrar boiadas, não boiadeiros (LEITE, 2003).

Estes dados chamam atenção por evidenciarem a escassez de dados disponíveis, mas também se apresenta como assunto emergente devido à ocorrência de mudanças que podem acarretar na perda do conhecimento deste segmento culturalmente diferenciado das populações tradicionais brasileiras. Acredita-se que o assunto pesquisado possui significativo valor no que diz respeito a uma forma de manejo $^{7}$ exercida por um conhecimento tradicional,

\footnotetext{
${ }^{6}$ Ver mais detalhes sobre as similaridades e diferenças entre estes ofícios a seguir, no item 2.1, p.77.

${ }^{7}$ Nesta pesquisa, adotou-se o termo manejo como o conjunto de ações e estratégias que visam a produção pecuária, sendo considerado como umas destas formas, o transporte do gado pelas Comitivas de boiadeiros. Segundo Pott (1994 apud RODELA et al., 2007, p. 4188), os criadores pantaneiros manejam a utilização dos
} 
aplicado há centenas de anos, e que no Pantanal, devido a seu regime de alagamento é, muitas vezes, a única alternativa de transportar o gado de uma região para outra.

Em referência à importância de pesquisas sobre populações tradicionais e os motivos pelo quais devemos estar atentos a esse conhecimento, podemos citar Marques (1999, p. 141), que conclui sobre seus estudos referentes a populações tradicionais:

[...] o foco das minhas preocupações, neste agora, concentra-se no fato de que esse conhecimento - chamemo-lo de nativo, tradicional, indígena ou como queiramos! - existe, resiste e está ameaçado. Esse conhecimento, além de extremamente útil, revela compatibilidade como a nossa ecologia - e no que ele não for compativel, muitas vezes trata-se apenas de uma questão de incomensurabilidade. Pois bem, esse conhecimento pode desaparecer. (...). Trata-se, na realidade, de um conjunto de sistemas de conhecimento altamente ameaçado de extinção e é isto o que mais me preocupa.

Em março de 2007, acredito que devido, principalmente, ao enfoque desta pesquisa, ganhei uma bolsa de estudos para o curso de um mês em um colégio na Inglaterra Schumacher College ${ }^{8}$, cujo tema era "Indigenous peoples \& the natural world: Is ancient wisdom important to the modern world?". Participaram pessoas de diversos países: Índia, Noruega, Austrália, EUA, Alemanha, Bélgica, Filipinas, entre outros. Só a existência deste curso e a representação de tantos países, já remete a relevância da discussão.

Um dos palestrantes, fundador do Fórum Social Mundial, Jerry Mander, colocou que embora a globalização exerça forte pressão para homogeneização do conhecimento, e o conhecimento indígena/tradicional ${ }^{9}$ signifique assim, uma visão atrasada na ótica do capitalismo e até mesmo um impedimento ao "progresso", ele afirma que a diversidade é a chave da vitalidade, resiliência e capacidade inovativa de qualquer sistema vivo. Isto vale

\footnotetext{
pastos nativos de duas formas. "O gado permanece durante o ano todo (maior ocorrência) ou o gado é colocado somente na fase seca e retirado na iminência da enchente. Para efetuar esta segunda forma de manejo, alguns criadores possuem duas propriedades, uma na planície e outra na parte alta, podendo fazer manejo para contornar os períodos críticos de forragem. (...). O período da retirada do gado depende da duração e intensidade da inundação, variável entre ano e local". Uma das formas de retirada deste gado, pode ser então, por meio das Comitivas de boiadeiros, além disto, as Comitivas também podem ocorrer quando há comercialização do gado e este precisa ser transportado.

${ }^{8}$ Schumacher College, Totnes - Devon. (www.schumachercollege.org.uk).

9 Nesta pesquisa, compreende-se o termo conhecimento indígena também como conhecimento tradicional, tal como foi utilizado durante o curso. Ver item 1.2.1, p. 55.
} 
também para sociedades humanas (informação verbal) ${ }^{10}$. Ainda segundo, Cavanagh; Mander (2004, p. 89):

The rich variety of human experience and potential is reflected in cultural diversity (grifo do autor), which provides a sort of cultural gene pool to spur innovation toward ever higher levels of social, intellectual, and spiritual accomplishment and creates a sense of identity, community, and meaning. ${ }^{11}$

No caso, a cultura pantaneira e em particular as Comitivas de boiadeiros representam uma atividade em que se realiza o transporte de espécies exóticas, o gado, inserida em determinadas paisagens $^{12}$. Estão expostas as influências do mundo exterior; mudanças ocorridas em seu meio, que podem alterar seus valores e atitudes e ao mesmo tempo, mudanças que podem advir do próprio homem, da sua criação, pois é um ir e vir que faz do sujeito a sua existência, estando no mundo e com o mundo.

Compreende-se que estas relações construídas entre homem e ambiente muitas vezes são contraditórias e exprimem práticas que podem tanto contribuir para conservação como degradar o meio em que vivemos. Admite-se então, que há impactos ambientais gerados pela atividade pecuária, assim como pelo movimento destas boiadas, mesmo no Pantanal, onde há extensas áreas de pastos nativos. Entretanto, nesta pesquisa não se pretende aprofundar sobre este tema, mas expor um pouco da complexidade do conhecimento dos boiadeiros que ocorre através do convívio com as paisagens pantaneiras.

Face às diferentes visões do homem, se buscou inserir neste fenômeno e perceber uma forma de manejo tradicional, como prática que está diretamente conectada ao ciclo das águas do Pantanal. Procurou-se descrever sobre o modo de vida dos boiadeiros e a estrutura desta atividade ligada a uma forma de leitura das diferentes paisagens do Pantanal, levando em conta a temporalidade dos acontecimentos e a dinâmica da sociedade.

\footnotetext{
${ }^{10}$ Informação fornecida por Jerry Mander durante o curso citado no texto, em 2007.

${ }^{11}$ A rica variedade de experiência e potencial humanos é refletida na diversidade cultural (grifo do autor), que prevê uma espécie de banco de genes culturais para estimular a inovação em direção a níveis cada vez maiores da vida social, intelectual, e realização espiritual e cria um senso de identidade, comunidade, e significado. (Tradução livre da pesquisadora).

12 Sobre paisagem, ver item 1.2, p.46.
} 
O acolhimento deste projeto no Programa de Pós-Graduação em Ciência Ambiental (PROCAM) pode me auxiliar justamente na visão interdisciplinar de pesquisa que o entendimento deste tipo cultural - o boiadeiro do pantanal - poderia ter. Pela minha formação em ecologia e crescente interesse em ciências humanas, o diálogo entre esses campos foi favorável ao tema pesquisado.

Este trabalho era para ser fundamentado através do acompanhamento presencial de Comitivas, mas no segundo semestre de 2007 sofri um grave acidente a cavalo e tive que interromper meus estudos por um ano e meio. No início do ano de 2009 renovei minha matrícula, mas por causa do meu estado de saúde, infelizmente, não foi possível acompanhar outras Comitivas, acarretando algumas alterações nos objetivos iniciais da pesquisa.

\section{Uma pesquisadora no ambiente de trabalho masculino}

Quando recebi a sugestão do comitê do PROCAM para escrever sobre o desafio da pesquisadora num contexto de pesquisa tipicamente masculino, apesar de saber da sua relevância, senti-me um pouco constrangida. Talvez pelo respeito com que os boiadeiros sempre me trataram ou talvez mesmo pela curiosidade latente e decorrência do trabalho, não havia parado para pensar sobre isso. Porém esta pergunta era recorrente quando expunha a pesquisa em diferentes âmbitos acadêmicos, afinal numa pesquisa com métodos qualitativos e dialógicos, essa questão pode ter fundamento, uma vez que se considera que a intersubjetividade é um assunto essencial.

A questão central da pergunta era pertinente, principalmente no que se refere à operacionalidade do acompanhamento das Comitivas e a interação/ tensão pesquisador, 
pesquisado durante o convívio e entrevistas com os boiadeiros. Como seria pra eles relatar o que vivem ou sentem, para uma mulher, e como seria se o fosse para um homem?

Acredito que por esta condição perdi algumas histórias e relatos, mas sei também que ganhei outros. O respeito que tive por eles foi sempre correspondido, e se em um primeiro momento eram mais fechados, no decorrer da Comitiva ou da entrevista ficavam cada mais familiarizados comigo e com meu compromisso de valorizar os saberes que relatavam, falando mais dos familiares e das dificuldades em suas vidas.

Sempre muito cuidadosos, davam-me o burro mais manso da tropa para montar e mesmo tendo o hábito de revezar seus burros para descanso, não quiseram, em nenhum momento trocar minha montaria. Apesar de estar acostumada a encilhar cavalos, nas viagens eu somente os auxiliava, pois queriam encilhar os animais para que estes estivessem bem seguros. Na primeira Comitiva, este cuidado foi tanto, que preocupados que eu sentisse dor por permanecer tanto tempo sobre o cavalo e com a intenção de deixar meu arreio mais confortável, ao invés de colocarem apenas um pelego ${ }^{13}$ sobre o mesmo (como de costume), quiseram colocar dois e infelizmente o efeito foi o oposto. Então, no ponto de almoço, pedi gentilmente para que retirassem um dos pelegos e mesmo não estando acostumada a andar o dia inteiro a cavalo, como andava com frequência, fiquei cansada, mas não tive nenhuma indisposição física.

Por eu querer conhecer um pouco de cada função na Comitiva, procurei não concentrar a atenção em uma só pessoa, a não ser que fosse alguém com mais experiência, mais velha, normalmente líder do grupo. Apenas durante a primeira Comitiva, não fui a única mulher que estava viajando, pois uma amiga, Elizabeth Leite (Bete), que também trabalhava na Pousada Caiman, quis ir conosco e assim, pudemos compartilhar algumas situações.

\footnotetext{
${ }^{13}$ Pelego é uma manta de lã e arreio pode ser considerado como um tipo de cela.
} 
Acabei por participar de poucas Comitivas, por motivos alheios a minha vontade e talvez, muito destes momentos tenham ocorrido com certa naturalidade por meu interesse nesta pesquisa ter surgido da relação com a experiência de meu avô materno e por já conviver, um pouco com a cultura dos peões pantaneiros. No que se refere às relações de classe, talvez por este motivo, também não senti que houvesse distanciamento ou diferenciação por ser pesquisadora. Na primeira Comitiva, realmente não estava nesta condição, mas mesmo durante as outras Comitivas, o que pude observar foi uma diferenciação cultural por ser de outro Estado, ou por ser "da cidade", e em alguns momentos notei que buscavam explicar-se melhor para que eu pudesse compreendê-los.

Porém é interessante colocar, que minha relação com os boiadeiros foi mais marcada pela relação de gênero. $\mathrm{O}$ trabalho que executam é predominantemente ocupado pela mão de obra masculina ${ }^{14}$, e pode ser que pela falta de costume com a presença feminina neste ambiente, havia todo o tempo, um excesso de zêlo e uma visão fragilizada da mulher. E assim, ficavam também surpresos por eu conseguir acompanhá-los.

Sobre questões mais difíceis de compreender para quem não tem uma imagem sobre a vida dos boiadeiros gostaria de partilhar um pouco desta relação assimétrica e heterogênea entre pesquisadora e pesquisados.

Para dormir numa comitiva, como dormem todos juntos, em redes individuais, não houve nenhum problema e estranhamento, mas para necessidades fisiológicas, como era ao ar livre, eu apenas esperava a Comitiva seguir, ficando para trás, buscando alguma moita e cuidando bem para meu burro não fugir! Já para tomar banho, talvez tenha sido o momento mais delicado. Fui preparada, levando traje de banho discreto, para tomar banho com eles em algum açude, rio, ou onde quer em que houvesse água disponível. Mas percebi que eles não queriam que eu fosse junto, pediam sempre para que eu fosse antes, que assim seria melhor.

\footnotetext{
${ }^{14}$ Oliveira (2004) e outras fontes orais têm conhecimento de apenas uma mulher que trabalhe em Comitivas. A mesma chama-se Mirela, é Condutora e aprendeu a profissão com o próprio pai.
} 
Por muitas vezes, também, quando estávamos chegando ao pouso, e se ocorria de estarmos próximos a alguma sede de fazenda, eles acabavam perguntando ao praieiro ${ }^{15}$ se havia algum banheiro disponível para banho, e antes mesmo de conversar comigo, já ficava tudo combinado.

Procurei aceitar o que me estavam orientando, pois eles ficariam mais à vontade e eu não os incomodaria. E assim, com cuidado, respeito e delicadeza, essas questões foram sendo resolvidas. Nos capítulos que seguem, um pouco mais sobre o perfil destes homens será relatado.

\section{Estrutura dos capítulos}

Para organização desta pesquisa, optou-se por dividí-la em capítulos. No primeiro capítulo apresenta-se breve contextualização do Pantanal e a formação do homem pantaneiro por meio da revisão da literatura sobre a região de estudo. Para maior familiarização ao assunto, foi feita uma introdução sobre estas paisagens relacionadas ao ciclo das águas, o que influencia diretamente na definição de roteiros das Comitivas. Em seguida, é retratado, de forma sucinta, o processo de ocupação e a consolidação da pecuária no Pantanal.

Ainda neste primeiro capítulo, busca-se retratar o marco conceitual e o caminho traçado neste estudo. O marco conceitual foi elaboradao a partir de uma abordagem sobre a interpretação cultural da paisagem como lugar no contexto de populações tradicionais. Já a

\footnotetext{
${ }^{15}$ Pessoa que toma conta dos arredores próximos a sede da fazenda. Termo este, que conheço em São Paulo como caseiro. Segundo Banducci Junior (1995) é o indivíduo que realiza as tarefas ligadas à praia, o terreno que circunda a casa grande, a diferença básica é que trabalha sem cavalo.
} 
trajetória metodológica se deu inicialmente, a partir de interrogações ${ }^{16}$ voltadas aos sujeitos que vivenciam o fenômeno ${ }^{17}$, ou seja, os boiadeiros no Pantanal Sul Matogrosssense. Posteriormente, por meio de coletas de entrevistas, histórias de vida, acompanhamento presencial de Comitivas, estes dados foram sendo construídos, analisados e tematizados (capítulos II, III, IV), compondo os elementos para buscar esboçar o universo cultural do boiadeiro de acordo com o recorte ao que se pretendeu pesquisar, ou seja, sobre seu modo de vida e as leituras das paisagens pantaneiras.

O segundo capítulo: Comitiva de boiadeiros - modo de vida está dividido em três subtemas. No primeiro, Viajantes do estradão foi feita uma descrição sobre o modo de ser boiadeiro. O segundo tema: Na batida das Comitivas de boiadeiros, trata-se de como ocorrem estas Comitivas, e o terceiro: Puxando a boiada, atenta-se para a divisão de ofícios nas Comitivas.

No terceiro capítulo: Comitiva pantaneira é dada a descrição sobre a leitura da paisagem. A partir do tema: Na Batida do estradão: Marcos referenciais nas paisagens, são tratados os significados atribuídos às paisagens pantaneiras. Já no tema: No ritmo das águas, são abordados os significados dados às estações sazonais, de acordo com a definição de trajetos nas Comitivas.

No quarto capítulo propõe-se Aproximações para uma conclusão, incluindo algumas reflexões acerca dos dados reunidos, bem como a importância e valorização do conhecimento dos boiadeiros. Por ser um assunto identificado como recorrente, também se procurou tratar sobre quais motivos têm levado às transformações recentes neste trabalho humano ou até mesmo o seu declínio, suas consequências e contradições. No último capítulo estão apresentadas as considerações finais, onde se procurou apontar as contribuições e limites deste trabalho, sugerindo novas linhas de pesquisa sobre o tema.

\footnotetext{
${ }^{16}$ Interrogação sugere algo mais amplo. Ver item 1.3 , p. 59.

${ }^{17}$ Ver definição de fenômeno na nota de rodapé $n^{\circ} 35$, p. 54.
} 
Todos estes temas e capítulos se interpenetram, porém são focados em grandes áreas, que procuram adentrar aos poucos ao mundo dos boiadeiros. Mundo este que se torna utópico a ser desvendado à medida que se conhecem cada vez mais as habilidades exigidas para este trabalho e suas dificuldades, mas não menos passível de apreender elementos que demonstrem uma relação de interdependência entre homem e ambiente. 


\section{CAPÍTULO 1 - O CAMINHO TRAÇADO NA PESQUISA}

No pantanal ninguém pode passar a régua. Sobre muito quando chove. A régua é existidura de limite. E o pantanal não tem limites. (...).

O mundo foi renovado, durante a noite, com as chuvas. Sai o garoto pelo piquete com olho de descobrir. Choveu tanto que há ruas de água. Sem placas, sem nome, sem esquinas. (...).

A pelagem do gado está limpa. A alma do fazendeiro está limpa.

Manoel de Barros (1990: 237).

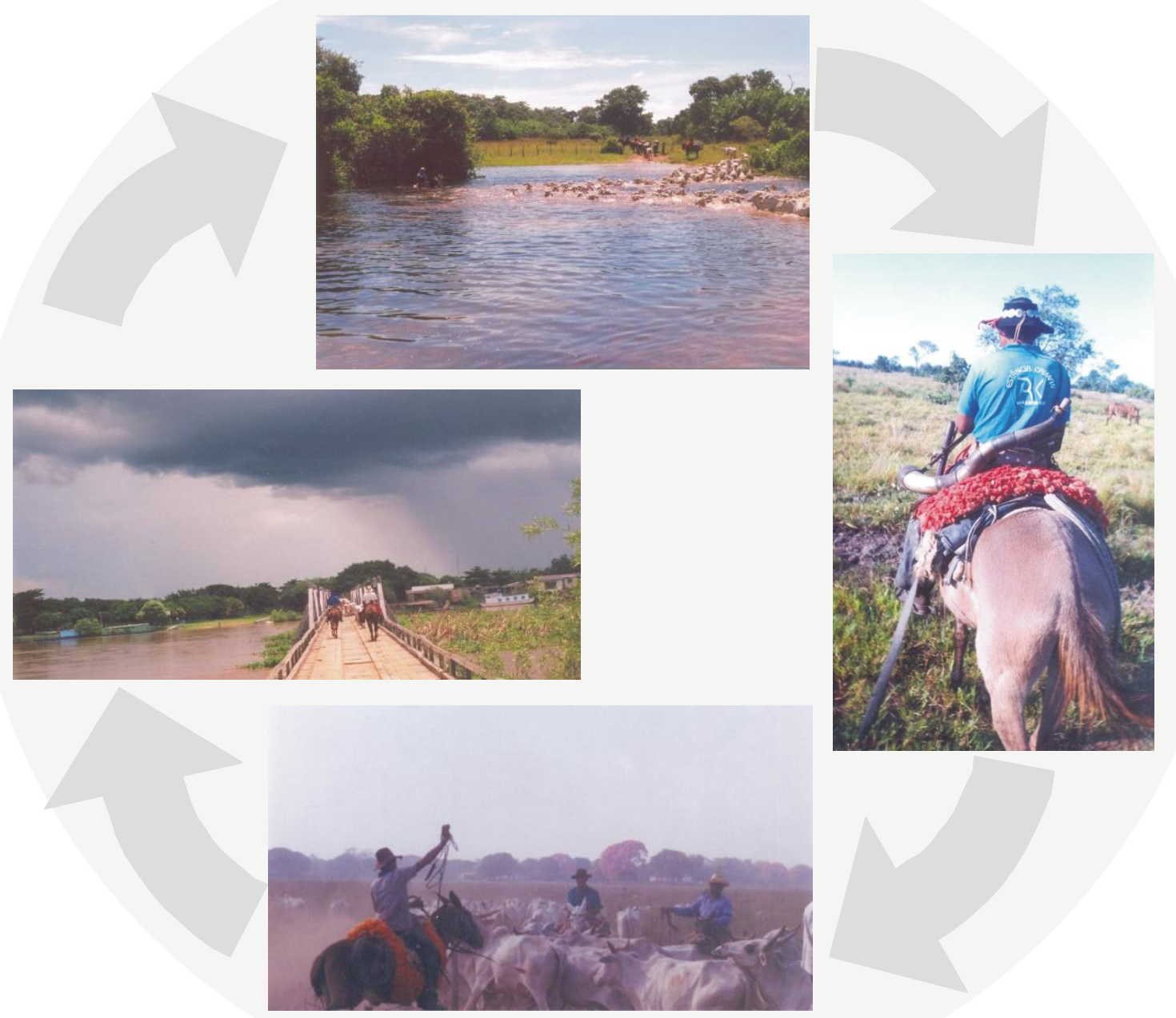

Fig. 9 - Ciclo das águas e boiadeiros no Pantanal-MS. (̇̀ esquerda seguindo o sentido da seta: 1. Enchente: Ponte sobre o Rio Miranda. Segunda Comitiva. 2.Cheia: Travessia Rio Cerradinho. Segunda Comitiva. 3. Vazante: Ponteiro Morcego. Primeira Comitiva. 4. Seca: Saída de Comitiva da Fazenda Fátima). Montagem das fotos: Juliana Moreno. 


\subsection{Contextualização do tema de estudo}

\subsubsection{O Pantanal}

É fundamental explanar sobre a dinâmica complexa nas paisagens do Pantanal, para que também se desvele o modo de vida e a leitura da paisagem pelos boiadeiros, pois estes são assuntos considerados interdependentes. É assim que afirma Proença (1997, p.72):

No Pantanal tudo depende das águas. São elas que condicionam os diversos tipos de lida, levam o homem a ter necessidade de mudanças nas grandes enchentes, modificam os solos, obrigam certas aves a migrar para outros lugares do planeta, empurrando o gado para cima das cordilheiras, quebram a monotonia da planície, ilhando muitas fazendas.

O Pantanal é a maior planície inundável do mundo. Sua área total é de $210.000 \mathrm{Km}^{2}$, abrangendo o Brasil, a Bolívia e o Paraguai. Deste total, $138.183 \mathrm{Km}^{2}$ estão no Brasil, ou seja, cerca de $70 \%$ ocorrem distribuídos entre os Estados do Mato Grosso e Mato Grosso do Sul. (ALHO; LACHER JUNIOR; GONCALVES, 1988). Neste último Estado, presente área de estudo, o Pantanal corresponde a $89.318 \mathrm{~km}^{2}$, equivalendo a $64,64 \%$ da área total do Pantanal no Brasil (ABDON e SILVA, 1998).

Ab' Saber (1988), discorre sobre a origem do Pantanal Matogrossense, propondo a teoria de que o que hoje é uma depressão teria sido no passado uma vasta abóbada de escudo, que funcionava como área de fornecimento de materiais detríticos para as bacias sedimentares do Grupo Bauru (Alto Paraná) e Parecis, formada até o Cretáceo. Durante o soerguimento pós-cretáceo teria ocorrido então, uma desestabilização tectônica, devido a falhamentos estruturais facilitando seu aplainamento e assim, comportando-se, como anticlinal esvaziada. Atualmente, o Pantanal Matogrossense se caracteriza por extensas planícies de acumulação de sedimentos fluviais. 
A planície pantaneira faz parte da Bacia do Alto Paraguai, que possui área de 496.000 $\mathrm{km}^{2}$, sendo ainda parte integrante da Bacia do Prata. Está sujeita a um regime das águas fortemente sazonal, com precipitação média de $1.396 \mathrm{~mm}$, variando entre 800 e $1.600 \mathrm{~mm}$. A declividade dos rios é de 0,1 a $0,3 \mathrm{~m} / \mathrm{km}$ com um gradiente topográfico de $0,3-0,5 \mathrm{~m} / \mathrm{km}$ na direção leste-oeste e 0,03-0,15 m/km na direção norte-sul. As altitudes na planície variam de 80 a 150 metros (AGÊNCIA NACIONAL DAS ÁGUAS, 2003).

De acordo com a classificação de Köeppen o tipo climático desta região é Aw, apresentando dois períodos distintos: chuvoso (outubro a março), quando ocorre cerca de $80 \%$ do total anual das chuvas e seco (abril a setembro). A temperatura média anual do ar é de $25,5^{\circ} \mathrm{C}$, com médias mínimas e máximas de $20^{\circ} \mathrm{C}$ e $32^{\circ} \mathrm{C}$, respectivamente (SORIANO, 2002).

Existe um atraso de aproximadamente quatro meses entre o pico da cheia do norte e do sul do Pantanal, o que faz com que a estação seca vigore na porção norte do Pantanal enquanto o nível das águas atinge seu pico na porção sul. Os níveis da água no norte são extremamente variáveis, subindo e descendo em resposta direta ao volume de chuvas. Os níveis da água no sul, por outro lado, aumentam e diminuem mais suavemente ao longo dos anos, devido à retenção natural da inundação que amortece as flutuações causadas pelas chuvas intensas Heckman ${ }^{18}$ (1999 apud HARRIS et al., 2005).

Os períodos mais frios, bem como a duração da estiagem são diferentes e imprevisíveis de ano em ano, resultando em fortes pressões sobre as populações animais e vegetais. Apesar disso, o solo hidromórfico e a forte inundação anual, que estende bastante dentro da seca, amenizam os efeitos dessas variações, pelo menos para parte dessas populações. (BROWN JUNIOR, 1984). Ou seja, enquanto algumas espécies se adaptam à constante mudança e

\footnotetext{
${ }^{18}$ HECKMAN, C.H. Geographical and climatic factors as determinants of the biotic differences between the northern and southern parts of the Pantanal Mato-grossense. In: SIMPÓSIO SOBRE RECURSOS NATURAIS E SÓCIO-ECONÔMICOS DO PANTANAL: MANEJO E CONSERVAÇÃO, 2., 1999, Corumbá. Anais.... Corumbá: EMBRAPA PANTANAL, 1999, p. 167-175
} 
sobrevivem às extremas condições, outras definem seus ciclos de vida de acordo com as estações.

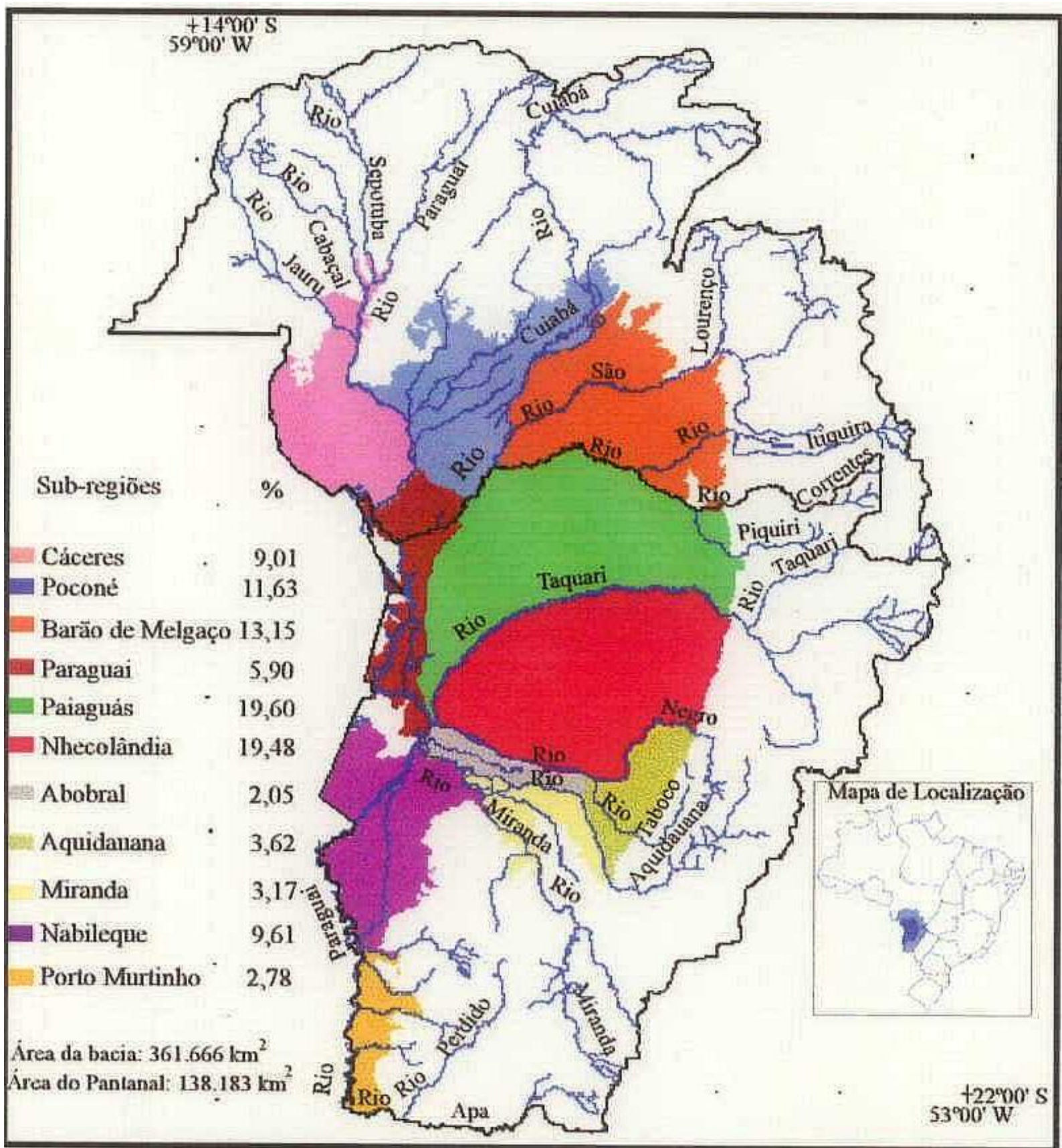

Mapa 1 - Sub- Regiões ou "pantanais" do Pantanal: Bacia do Alto Paraguai no Brasil. Fonte: Silva; Abdon (1998). 
A vegetação é heterogênea e influenciada por quatro biomas: Floresta Amazônica, Cerrado (predominante), Chaco e Floresta Atlântica. Adamoli ${ }^{19}$ (1981 apud HARRIS et al., 2005). Segundo Silva et al. ${ }^{20}$ (2000 apud HARRIS et al, 2005), um levantamento aéreo do Pantanal brasileiro identificou 16 classes de vegetação com base nas fitofisionomias, sendo os campos a fisionomia mais representativa (31\%), seguida do cerradão (22\%), cerrado (14\%), campos inundáveis (7\%), floresta semidecídua (4\%), mata de galeria $(2,4 \%)$ e tapetes de vegetação flutuante ou 'baceiros' $(2,4 \%)$.

É devido a este mosaico de fisionomias vegetais que a região é considerada como Complexo Pantanal, sendo declarado Patrimônio Natural da Humanidade e Reserva da Biosfera (ORGANIZAÇÃO DAS NAÇÕES UNIDAS PARA A EDUCAÇÃO, A CIÊNCIA E A CULTURA, 2009). Sua importância também está estabelecida na Constituição brasileira, no artigo 225, § $4^{\circ}$, sendo reconhecido como Patrimônio Nacional.

As principais razões pelas quais o Pantanal merece este reconhecimento internacional podem ser elencadas em: trata-se de um complexo de ecossistemas únicos no mundo; constitui o habitat de espécies animais e vegetais diversificadas, muitas delas consideradas raras e algumas em processo de extinção; é protegido nacionalmente; pertence e tem influência sobre mais de um país; revela em muitos aspectos uma sociodiversidade peculiar dada ao processo histórico de formação sócio-espacial. Essa formação é conhecida popularmente como a cultura do pantaneiro - por seu trabalho, culinária, vestuário, costumes, festas, suas manifestações artísticas e religiosas. (WERTHEIN, 2000).

\footnotetext{
19 ADÁMOLI, J. 1981. O Pantanal e suas relações fitogeográficas com os cerrados. Discussão sobre o conceito de "Complexo do Pantanal". In: Anais do XXXII Congresso Nacional de Botânica. pp. 109-119. Sociedade Brasileira de Botânica, Teresina, 1981

20 SILVA, M.P. da, e tal. Distribuição e quantificação de classes de vegetação do Pantanal através de levantamento aéreo. Revista Brasileira de Botânica, 2000. 23: 143-152.
} 


\subsubsection{O homem pantaneiro e a pecuária}

Diegues Junior (1960) caracterizou o Brasil em regiões culturais, através do processo de ocupação humana em estabelecimentos de exploração econômica, como núcleos de povoamento que conferia uma organização social e criava tipos sociais a ele ligados. Deste modo, constituiu-se o ambiente das relações entre estes grupos étnicos, que participaram da formação sócioespacial brasileira e igualmente das relações culturais, com todas suas diversidades e peculiaridades. Os engenhos de açúcar foram os primeiros focos de povoamento criados e desenvolvidos no Brasil, logo depois apareceram as "fazendas de criação; de um lado, das necessidades do engenho em gado para determinados trabalhos e para alimentação e de outro lado, do desenvolvimento natural da pecuária” (Id., 1952, p.11). Ainda segundo este autor "foi na fazenda que se fundamentou a estrutura social do Brasil; definiu-se esta preferentemente, ou mais exatamente, nas áreas rurais, e só modernamente se pode considerála em função do meio urbano" (DIEGUES JUNIOR, op. cit., p. 84).

Foi assim também que ocorreu a ocupação no Centro Oeste e consequentemente, no Pantanal. A origem do pantaneiro é produto da miscigenação entre as diversas sociedades indígenas que habitavam a região, os colonizadores e os escravizados negros africanos que chegaram após o século XVI. (Id., 1952). Entre os indígenas estavam os Guató, Guaicuru, Terena, Payaguás, Kayapós e Bororo, sendo que, atualmente, muitos deles são apenas remanescentes de uma história que não se deixou contar.

Apesar das primeiras invasões terem sido dos espanhóis, a colonização massiva do Pantanal começou no século XVIII. Segundo Silva e Silva (1995), inumeráveis bandeiras foram expedidas com o objetivo de povoar e explorar recursos naturais, principalmente o ouro, iniciando nessa época, os conflitos interétnicos, que causaram o declínio das sociedades indígenas. 
O rápido esgotamento do ouro, já na primeira metade do período setecentista, levou à procura de novas áreas mineradoras, como a do Vale do Guaporé, na bacia amazônica (COSTA, 1999). Em Mato Grosso ${ }^{21}$, as populações desenvolveram outras atividades, sem prejuízo da continuidade da exploração mineira nas margens de rios - a extração da erva mate na região sul, a pequena agricultura e a criação de gado no Pantanal, onde surge um tipo característico de gado, o boi pantaneiro, em mestiçagem com o zebu. (DIEGUES JUNIOR, 1960). A gradativa introdução de lotes de gado para a subsistência da região foi constituindo o que viria a ser a expressiva pecuária no Pantanal.

Logo após 1719, (...) sentiu-se a necessidade de importação de gado vacum como prenúncio da vocação agropecuária da região (...) Assim, adquiriramse as primeiras reses da história de Mato Grosso, que se tornou autônomo em 1748. Provenientes, por certo, de criatórios paulistas, os lotes precursores chegaram por via fluvial, de canoas, pelo roteiro das monções. (...) encontraram bom meio ambiente, pastos ótimos, abundantes, água com fartura. Cresceram, engordaram e multiplicaram-se. (SOUZA, 1986, p. 202).

A pecuária, iniciada há mais de duzentos e cinquenta anos, continua com o mesmo regime de criação extensivo nas pastagens. O manejo tradicional das pastagens, baseado na experiência de sucessivas gerações, consiste na utilização da cobertura vegetal nativa e nas reservas de vegetação original, chamadas capões (locais importantes para o trato com o gado, porque os abriga das chuvas e do frio). Outro tipo de manejo é a prática da "veda", ou seja, a retirada do gado do campo para a recuperação natural das forrageiras, e a queimada utilizada para a limpeza e manutenção do pasto. Estas técnicas utilizadas são elementos da cultura material do pantaneiro e permanecem em algumas fazendas. (ABDON e SILVA, 1998).

Ainda que o gado tenha sido uma espécie introduzida, alguns autores atestam que a pecuária extensiva é uma aptidão agroecológica do Pantanal (MOURÃO et al., 2000), tendo sido responsável pela manutenção do equilíbrio e da sustentabilidade desses ecossistemas. Entretanto, apesar desta afirmação, Abdon e Silva (1998), reconhecem que, as inovações tecnológicas como inseminação artificial, criação de novas raças e a substituição das

\footnotetext{
${ }^{21} \mathrm{Na}$ data referida, Mato Grosso do Sul não era um estado independente, o que veio ocorrer apenas em 1977.
} 
forrageiras nativas pelas exóticas (com maior teor nutritivo para o gado), sinalizam transformações substanciais na antiga relação do pantaneiro tradicional com o ecossistema, colocando em risco o estereótipo do "convívio harmonioso", responsável pela sustentabilidade da região.

Segundo Campos Filho (1998) pode-se dizer que uma crise na identidade pantaneira instalou-se a partir de uma violenta entrada de migrantes e agenciamentos globalizantes, através de novos interesses, desejos e necessidades, deixando perplexa sua população. No entanto, enquanto alguns estavam seduzidos, outros internalizavam aportes externos e ainda havia aqueles que permaneceram incólumes ao passado.

Em relação à dimensão das áreas das fazendas, também houve alterações. Hoje tem ocorrido a retaliação das mesmas para contemplar os direitos dos muitos herdeiros dos grandes fazendeiros. Além disto, a lucratividade do gado está diminuindo e muitos têm procurado outras atividades para sobreviver, como é o caso do ecoturismo (FRUET, 2004). Estes fatores podem significar aumento na pressão de produção pecuária, em áreas cada vez menores, caso haja aumento no número de cabeças de boi por unidade de área.

A economia pantaneira caracteriza-se então, basicamente, por atividades agropecuárias nas fazendas da região ou em pequenas propriedades nas beiras dos rios. A pesca também significa fonte de emprego e renda, incluindo a pesca esportiva, que está diretamente associada ao turismo. Essas atividades revelam o contraste entre os períodos de estiagem e o das grandes enchentes. (ARRUDA; DIEGUES, 2001).

Há estimativa de que o rebanho bovino no Pantanal seja constítuido de 3,8 milhões de indivíduos (POTT; VIEIRA; COMASTRI FILHO, 2008), o que fazem da pecuária de corte a principal atividade econômica do Pantanal. Esta pecuária baseia-se nas fases de cria e recria, com a comercialização de bezerros de sobreano, bois magros e vacas de descarte, que tendem 
à raça Nelore. A produtividade animal é limitada pelo regime de cheias e de secas. Pott; Catto; Brum (1989 apud MAZZA et al., 1994). ${ }^{22}$

O transporte das reses pode ser realizado por ferrovia, rodovia, via fluvial e a pé, dependendo dos métodos de comercialização, tipos de animais, custos e disponibilidade destes meios, porém, grande parte deste rebanho faz longos percursos a pé. (ABRÃO, 1983). Nesse último caso, é através das Comitivas de boiadeiros que são transportados.

A transumância de animais tem sido realizada em diversos países há milhares de anos. É uma atividade que possui importância histórica, sócio-econômica e ambiental, pois tem ocorrido, concomitantemente, às ocupações humanas e colonizações, isto quer dizer, ao desenvolvimento das civilizações em diferentes paisagens. Em muitos países e em Estados brasileiros está atividade se extinguiu devido a fatores como, por exemplo, a construção de rodovias e mudanças de produção para escalas industriais. Sabe-se que no Pantanal as Comitivas permaneceram, mas compreender como têm permanecido e quando são optadas, faz parte da abordagem desenvolvida neste trabalho.

\subsection{Marco conceitual: A interpretação da paisagem como lugar no contexto de populações tradicionais}

Apresenta-se a seguir algumas reflexões e referenciais sobre conceitos ${ }^{23}$ chave que foram adotados no desenvolvimento da pesquisa. Cabe dizer que não se pretende esgotá-los ao defini-los, mas delinear em quais campos do conhecimento optou-se por construir

\footnotetext{
${ }^{22}$ POTT, E.B., CATTO, J.B., BRUM, P.A.R. Períodos críticos de alimentação para bovinos em pastagens nativas no Pantanal Mato-Grossense. Brasília: EMBRAPA, 1989.

23 "Os conceitos são construções lógicas, estabelecidas de acordo com um quadro de referências. Adquirem seu significado dentro do esquema do pensamento no qual são colocados.” (MENDONÇA, 1983, p. 17).
} 
diálogos. A intenção é fazer-se entender melhor, quando citados durante o texto e identificar no campo da linguagem acadêmica os referenciais teóricos de apoio.

O marco conceitual desta pesquisa é a interpretação da paisagem como lugar no contexto de populações tradicionais. Assim, seguem aproximações a partir de autores que beneficiam estas complexas conexões entrelaçando diferentes áreas do conhecimento. Procurou-se utilizar o que se considera essencial dentro desta perspectiva, mas é evidente que os conceitos e autores citados estão incorporados a linguagem da dissertação.

FURLAN $^{24}$ coloca que as possibilidades de abordagem interdisciplinar têm demonstrado dificuldades e avanços. Tratando-se dos avanços são propostas três dimensões: (informação pessoal):

1) Temática; onde temas multidisciplinares são expostos, mas não estão conectados conceitualmente.

2) Conexões por procedimentos metodológicos; onde é estabelecido um diálogo entre campos do conhecimento através de procedimentos operacionais. Como por exemplo, a interface deste trabalho entre a descrição contextualizada de Geertz (1989) e a paisagem cultural (vários autores) ${ }^{25}$, através da leitura da paisagem.

3) Conexões por conceitos; onde é estabelecido um diálogo entre categorias, noções e conceitos de diferentes campos do conhecimento. Neste trabalho podemos exemplificar a conexão entre paisagem e cultura através de autores como Claval (2001) e Geertz (op. cit.).

Conceitos abrangentes como paisagem e cultura são importantes interfaces neste estudo sobre o homem e suas relações com o ambiente, ou seja, as Comitivas de boiadeiros no Pantanal Sul Mato-Grossense. Mais especificamente a Antropologia Cultural com o conceito interpretativo de cultura e na Geografia de abordagem humanista, com o conceito de paisagem cultural. Nesse sentido admite-se a afirmação de Nogueira (2002), que compreende

\footnotetext{
${ }^{24}$ FURLAN, S. Â. Informação fornecida durante reunião de orientação em 17 de set. 2009.

${ }^{25}$ Tais como Claval (1999, 2001) e Meneses (2002).
} 
o pantanal e o pantaneiro como duas entidades que se fundem numa realidade antropogeográfica única.

É importante ressaltar que a investigação sobre o modo de vida e a cultura dos boiadeiros emergiu, principalmente, através de métodos empíricos fundamentados em dados primários obtidos durante esta pesquisa e em trajetórias de vida anteriores na região estudada. Por este motivo, os conceitos da Antropologia proporcionaram amparo em certos procedimentos, a partir da descrição contextualizada, possibilitando uma segurança metodológica.

Segundo Geertz (1989, p. 37) fazer etnografia é como tentar ler (no sentido "construir uma leitura de") um manuscrito estranho, desbotado, cheio de elipses, incoerências, emendas suspeitas, comentários tendenciosos, buscando interpretar estes dados e compreender experiências variadas. Desta forma é enfatizada a descrição ${ }^{26}$ contextualizada e minuciosa, onde se procura não generalizar através dos casos, mas dentro deles. A etnografia significa, nesta pesquisa, observar e compreender relações, experiências vividas, selecionar e entrevistar informantes, transcrever textos, aprender vocabulários, mapear campos, manter um diário.

Além disso, dada à complexidade do conceito de cultura, optou-se pelo conceito adotado por este autor, que a coloca "como sistemas entrelaçados de signos interpretáveis (o que eu chamaria símbolos, ignorando as utilizações provinciais”. Este sistema simbólico é compreendido como um sistema de concepções, percepções, sem o qual não haveria o homem. Nossas idéias, nossos valores, até mesmo nossas emoções são, como nosso próprio sistema nervoso, produtos culturais - manufaturados a partir de tendências, capacidades e disposições. Assume-se que "homem é um animal amarrado a teias de significados que ele mesmo teceu", sendo a cultura, estas teias e sua análise. O autor propõe então, uma abordagem semiótica da cultura, auxiliando a ganhar acesso ao mundo conceptual no qual vivem os nossos sujeitos, de

\footnotetext{
${ }^{26}$ Sobre descrição, ver ítem 1.3, p. 60.
} 
forma a podermos, num sentido um tanto mais amplo, conversar com eles, interpretando os significados que emergem de sua fala. (GEERTZ, 1989, p.15-24).

Para construir conexões importantes com o conceito de paisagem buscou-se na literatura geográfica autores que puderam se alinhar a esta concepção descrita acima. Claval (1999) ressalta a emergência sobre a discussão de temas relacionados à afirmação cultural de povos, lugares, etnias e identidades culturais em determinadas paisagens como diferenciação social. Deste modo, propicia a construção do diálogo com a antropologia de Geertz (op. cit.), através da observação participante, a descrição etnológica.

Antes de aprofundar o modo como se trabalhou o conceito de paisagem é necessário um pequeno preâmbulo sobre o tema. Considera-se que a paisagem é uma palavra polissêmica, e que esta flexibilidade de significados pode trazer vantagens, mas também a banalização. Mesmo sendo uma categoria chave da Geografia, também utilizado na História, e embora ambas as ciências tenham elaborado sólidos conceitos, estas não a definem como fato cultural, pois não basta "supormos um objeto (uma extensão da superficie da terra), a ação humana que o transforma e a interação (material ou simbólica) que se estabelece”, é preciso considerá-la como processo cultural. (MENESES, 2002, p. 31).

O conceito de paisagem cultural foi proposto por Carl Sauer, sob influência da Geografia Alemã e influenciando a Geografia Cultural $^{27}$ norte americana, pela Escola de Berkeley. Sua primeira obra teórica importante foi Morfologia da paisagem, publicada em 1925, onde se ponderou a ação humana para caracterizar a paisagem, respeitando a diversidade de temas e de interesses como "modus vivendi", o que a mantém aberta para temas novos como o da percepção ambiental, e propondo assim, uma visão interdisciplinar (SAUER, 1925). Seus

\footnotetext{
${ }^{27}$ A Geografia cultural é o campo da Geografia Humana que surge por volta do século XX, como alternativa ao pensamento determinista sobre o meio ambiente. Esta abordagem se caracteriza pelos estudos voltados às relações entre sociedade, cultura, natureza e paisagem, principalmente no que se refere a cultura material (artefatos, técnicas, utensílios, habitat e instrumentos de trabalho). (ZANATTA, 2010; MATHEWSON; SEEMANN, 2008).
} 
trabalhos valorizaram o trabalho de campo, a observação, a descrição e a explicação de acordo com os melhores métodos ao nosso alcance, mas sem postulados a priori. (SAUER, 2000).

Apesar das críticas a este autor, é reconhecida sua contribuição efetiva para que novas abordagens e temas fossem incorporados à Geografia. (CORRÊA, 2001). Por propor o conceito paisagem cultural sob influência da Antropologia e da História, este autor significa uma aproximação interessante para esta pesquisa e é mais uma razão para construção de uma abordagem apoiada na representação (simbólica e material).

A partir da década de 70, Claval (2001) expõe que transformações nos estudos culturais conduzidos pelos geógrafos começam a incluir a expressão de processos cognitivos, de atividades mentais, percepções, ou seja, as relações entre homens com o meio ambiente e espaço, medidos pela representação simbólica. O papel das paisagens para os grupos humanos é considerado complexo e passa a desempenhar um suporte de mensagens e símbolos, traduzindo-se no significado dado pela experiência vivida de diferentes grupos sociais ${ }^{28}$.

Ou seja, são experiências subjetivas que revelam desejos, aspirações, sonhos.

No momento em que as paisagens deixam de ser consideradas como realidades objetivas, a maneira como são concebidas pelas populações locais torna-se um tema de estudo apaixonante. (Ibid., p. 57).

Nesta pesquisa admite-se que a paisagem não é universal, não possui apenas objetividade morfológica, nem somente é objeto real que se dá a percepção, pois isso a resumiria como mera projeção do observador, assume-se que "é considerando a paisagem uma estrutura de interação que se tem sua verdadeira natureza cultural”. (MENESES, 2002, p. 32).

Dada a relevância do conceito de paisagem, a Constituição brasileira de $1988,{ }^{29}$ a introduz no corpo do "Patrimônio Cultural Brasileiro", o que gerou diversas discussões entre a dicotomia cultura e natureza, mas é no Encontro Técnico do Comitê do Patrimônio Mundial

\footnotetext{
${ }^{28}$ O autor é o precursor destas idéias, que fazem parte da Nova Geografia Cultural.

29 (BRASIL, 1988). Constituição Federal, art. 216, §v.
} 
em La Petite, França, 1992, que ocorre a introdução da categoria paisagem cultural referindose a "obra combinada da natureza e do homem" 30 .

Desta forma, compreendendo o homem e a paisagem como indissociáveis, podemos afirmar que a paisagem tem história, que ela pode ser objeto de conhecimento histórico e que essa história pode ser narrada. Isto diz respeito também os usos que dela fizeram as sociedades ou segmentos sociais, onde "se concentram os significados mais profundos da paisagem", sendo possível explorá-la nas mais variadas direções, e interpretá-la através de certos códigos de leituras ${ }^{31}$. O papel da paisagem é indiscutível no campo da identidade e dos processos identitários desempenhando como "componente na fixação das identidades nacionais". Esta necessidade de incluir nossa trajetória bibliográfica não só num eixo temporal, mas também espacial, atende a requisitos de produção e reprodução material da vida, e que vem carregada de sentidos, emoções, valores, expectativas, sendo indispensável em nossa interação consciente com o mundo (MENESES, 2002, p. 41).

$\mathrm{Na}$ percepção do mundo e do consumo de recursos (utilitários ou simbólicos) desse mundo, os significados incorporados nos objetos ambientais são canalizados para as experiências dos sujeitos. A percepção de mundo e a constituição daquilo que é importante ou desimportante para as pessoas não funciona em termos de 'uma lousa ambiental em branco', que é operada pela percepção e cognição, mas em termos de historicidade e das experiências vividas nesse mundo. Tilley ${ }^{32}$ (1994 apud Ibid., p. 60).

Homem e natureza são constituintes do mesmo universo, que a percepção não fragmenta, onde se deve incluir não só as leituras dos sujeitos que vivenciam o cotidiano nestas paisagens, mas também as interações resultantes das experiências de vida e entre pesquisador e pesquisa. São múltiplos olhares permeados com intencionalidades de sujeitos distintos, que dão a paisagem significados complexos.

\footnotetext{
${ }^{30}$ A United Nations Educational Scientific and Cultural Organization (UNESCO) define paisagem, separando-a em 3 classes: designed cultural landscape; organically evolved landscape e associative cultural landscape. Disponível em: <http://whc.unesco.org/en/culturallandscape〉. Acesso em: 10 set. 2009.

${ }^{31}$ No item 1.2, p. 41, está explicitada uma das formas de leitura da paisagem.

${ }^{32}$ TILLEY, Cristopher. A phenomenology of landscape. Places, paths and monuments. Oxford: Berg, 1994.
} 
Schama (1996, p. 17) descreve detalhadamente suas memórias e imaginações de infância relacionadas à percepção da paisagem e conclui que se a visão de uma criança já consegue comportar lembranças, mitos e significados complexos, muito mais elaborada deve ser a visão dos adultos.

Pois, conquanto estejamos habituados a situar a natureza e a percepção humana em dois campos distintos, na verdade elas são inseparáveis. Antes de poder ser um repouso para os sentidos, a paisagem é obra da mente. Compõe-se tanto de camadas de lembranças quanto estratos de rochas.

A paisagem significa uma construção da imaginação projetada como sobre matas, água e rochas, compreendendo assim, que "quando uma determinada idéia de paisagem, um mito, uma visão, se forma num lugar concreto, ela mistura categorias, torna as metáforas mais reais que seus referentes, torna-se de fato parte do cenário”. (Ibid., p. 70).

Este autor coloca que o funcionamento de vários ecossistemas pode atuar independente do homem, mas assim como Balée (1994), Posey (2006), Diegues (1996) compreende que é difícil imaginar um único sistema natural que a cultura humana não tenha modificado, reconhecendo que embora o impacto da humanidade sobre a ecologia da terra não tenha sido "puro benefício", a longa relação entre natureza e cultura tampouco tem sido uma "calamidade irremediável e indeterminada" (Ibid., p. 20).

A reflexão destes autores contribui no processo de construção do diálogo entre os conceitos de cultura e paisagem adotados neste estudo, devendo ser compreendidos como um fenômeno integrado, como um fluxo contínuo de interação cultura e ambiente, que transforma ambos. Assim propõe o antropólogo Balée (op. cit; p. 24), a partir da sua experiência em etnografia e etnobotânica: "comunidades e culturas humanas, junto com as paisagens e regiões, com as quais elas interagem ao longo do tempo podem ser compreendidas como fenômenos totais" ${ }^{, 3}$. Podemos fazer uma analogia à conceituação de outro importante geógrafo sociocultural Ab' Saber (2004, p. 222) quando trata da relação dinâmica e integrada com

\footnotetext{
${ }^{33}$ Tradução livre da pesquisadora.
} 
espaços produzidos pelo homem sobre os espaços herdados da natureza como espaço total ${ }^{34}$. Desta forma, considera-se a paisagem como herança de todos estes processos que envolvem também idéias de incompatibilidades de funções sociais e econômicas ocorrentes em diferentes subespaços e regiões.

Neste sentido, Cabrera et al. (2001) definem que as áreas culturais contextualizadas por uma região geográfica são complexos culturais inter-relacionados que seguem uma continuidade no espaço-tempo. Assim, busca-se "compreender como a vida dos indivíduos e dos grupos se organiza no espaço, nele se imprime e nele se reflete”, se avaliando a "dialética das relações sociais no espaço, com sua ligação ao meio ambiente e ao papel complexo das paisagens, ao mesmo tempo suportes e matrizes das culturas”. (CLAVAL, 2001, p. 40).

Nesta dissertação procurou-se ponderar também, que a natureza processual complexa da paisagem ocorre e se explica a partir de processos sociais e naturais ${ }^{35}$, em certos contextos, sendo necessário compreendê-la como um tema que permeia diversos campos do conhecimento, incluindo o conhecimento não formal e o conhecimento de populações tradicionais. Trata-se de um espaço que vai além da observação, é um espaço construído a partir de vivências, sentidos e "expêriencias compartilhadas", e pensada "como um vasto campo de significados, tensões e contradições". Além disto, ela "é instável, um permanente vir a ser e permanência em transformação". (SANDEVILLE, 2005, p.1- 9)

Sobre o espaço, uma categoria complexa para a Geografia, entende-se como as idéias de um grupo ou um povo, a partir da experiência cotidiana, seus sentimentos e emoções. Esse

\footnotetext{
34 "Espaço total (grifo do autor): o mosaico das heranças da natureza integradas com as heranças positivas ou negativas das ações cumulativas feitas por gerações e gerações de homens. (AB' SABER, 2004, p. 222).

${ }^{35}$ Entende-se processos naturais como inscritos em um campo de fenômenos e processos sociais em um campo de conflitos, tensões, de intencionalidade. Considerando que estes processos também interagem. (SANDEVILLE, 2005).
} 
espaço vivido seria como um campo de representações cheio de simbolismos, que pode ter sentido pessoal, ou estar ligado à experiência ${ }^{36}$ do outro como grupal ou mítico-conceitual.

Compreende-se o espaço também como algo que permite movimento, que tem a capacidade de mover-se e por este motivo pode ser experenciado de várias maneiras: como a localização relativa de objetos e lugares, como as distâncias e extensões que separam ou ligam os lugares, e - mais abstramente - como a área definida por uma rede de lugares. (TUAN, 1983, p.14).

Apesar do significado de espaço e lugar fundirem-se na experiência, o "espaço" é mais abstrato na linguagem de Tuan, inicialmente pode ser denominado como espaço e a medida que o conhecemos e dotamos um valor ${ }^{37}$ torna-se "lugar". As idéias de "espaço" e "lugar" não podem ser definidas uma sem a outra, a partir da segurança e estabilidade do lugar estamos cientes da amplidão, da liberdade, do movimento e da ameaça do espaço, e vice-versa. (Ibid, 1983).

Neste sentido, o lugar é um mundo de significado organizado, sendo essencialmente um conceito estático, "se víssemos o mundo como processo, em constante mudança, não seríamos capazes de desenvolver nenhum sentido de lugar". Mesmo que certas sociedades estejam em constante movimento, como no mundo dos nômades, há o sentido de lugares conectados por um vínculo, porque há uma percepção intersubjetiva dos lugares. Os nômades acampam quase sempre nos mesmos lugares (pastagens e cacimbas). (Id., 1986, p. 198).

O lugar significa também, pausa e cada pausa no movimento torna possível que localização transforme-se em lugar, é um objeto no qual se pode morar. (Id., 1983). No caso

\footnotetext{
${ }^{36}$ Experiência é um termo que abrange diferentes maneiras através das quais a pessoa constrói e apreende a realidade, significa atuar sobre o dado e criar a partir dele. Então, o dado não pode ser conhecido em sua essência, a realidade conhecida é a construção da experiência sobre o mesmo. (TUAN, 1983).

${ }^{37} \mathrm{O}$ significado de valor para Tuan (1983) está relacionado ao que as pessoas pensam, sentem sobre o espaço e lugar, as diferentes maneiras de experenciar (sensório motora-tatil, visual, conceitual) e interpretá-los como imagens. É um mundo complexo, muitas vezes de percepções ambivalentes.
} 
dos boiadeiros os lugares podem ser representados, durante as viagens, pelos pontos de parada para almoço e pouso.

Compreende-se que para aprender a conhecer os lugares é necessária a identificação de locais significantes, o que no espaço delimitado pelas viagens dos boiadeiros podem ser estradas e outros diversos referenciais nas paisagens pantaneiras. Estes objetos e lugares são "núcleos de valor", por receber ou possuir nomes, e representar sentimentos, impressões que contribuem como formas de orientação. (TUAN, 1983, p. 20).

Neste caso de estudo, como ocorre na maior parte das vezes, estas habilidades como orientação no espaço, atividades rotineiras, tarefas usuais ou até mesmo a afeição por certos lugares são aprendidas não através da instituição formal, mas principalmente ocorre ao nível do subconsciente. Distâncias podem percebidas através de diversos sentidos como a visão, a audição, sendo compreendidas através de símbolos numéricos ou verbais calculados, tal como para os boiadeiros, que podem contar os dias de viagem em marchas $^{38}$. (Ibid., 1983).

E é através do "estar no mundo", experenciá-lo, de escutar conversas fiadas ou coisas corriqueiras da vida, que há a possibilidade em "complexar" este conhecimento tornando-o analítico. (Ibid, p. 221).

\subsubsection{Populações tradicionais}

O conceito de população tradicional tem gerado muitas discussões, devido sua complexidade e abrangência. A expressão surge a partir do Congresso de Áreas Protegidas de 1992, como uma forma de identificar comunidades não indígenas que mantém um modo de vida diferenciado da sociedade urbano-industrial. Contudo, durante a regulamentação da Lei

\footnotetext{
${ }^{38}$ Cada marcha representa cerca de 12 quilômetros ou 1 dia de viagem.
} 
$\mathrm{n}^{\text {o }}$ 9985/ 2000 (BRASIL, 2000) ${ }^{39}$, este significou um dos pontos de maior divergência nos debates jurídicos e acadêmicos. No texto original, vetado, em seu art. $2^{\circ}$, inciso $\mathrm{XV}$, era definido como:

Os grupos humanos culturalmente diferenciados, vivendo há, no mínimo, 3 gerações em um determinado ecossistema, historicamente reproduzindo seu modo de vida, em estreita dependência do meio natural para sua subsistência e utilizando os recursos naturais de forma sustentável.(Ibid., $p$. 1)

O veto foi uma atitude política justificada pela bancada ruralista que se opôs veemente a inclusão desta definição em virtude de o conteúdo da disposição ser tão abrangente que dificultava a identificação das populações como "tradicionais", pois um determinado agrupamento humano não pode ser tido como tradicional apenas pelo fato de habitar continuamente em um mesmo ecossistema. Além disso, nem a definição de ecossistema nem o número de gerações se prestam à função de delimitar benefícios e tampouco definir se uma população enquadra-se como tradicional. O número de gerações não traz, necessariamente, a noção de permanência temporal em um determinado local. De qualquer modo, o que se tem observado é que o SNUC (Sistema Nacional de Unidades de Conservação) permitiu que novos vínculos fossem estabelecidos entre Unidades de Conservação e estas populações por meio do processo participativo. (QUEIROZ; SILVA, [c.a 2000]).

Com o Decreto Federal no 6040/ 2007 (BRASIL, 2007) ${ }^{40}$, o governo instituiu a Política Nacional de Desenvolvimento Sustentável dos Povos e Comunidades Tradicionais (PNPCT), reconhecendo, formalmente, pela primeira vez na história do País, a existência de todas as chamadas populações "tradicionais" do Brasil e estendendo o reconhecimento feito parcialmente, na Constituição de 1988, apenas aos indígenas e aos quilombolas. Desta vez, incluindo o conjunto das populações tradicionais de faxinenses (que plantam mate e criam

\footnotetext{
39 (BRASIL, 2000:1). Lei n. ${ }^{\text {o } 9985 . ~ I n s t i t u i ~ o ~ S i s t e m a ~ N a c i o n a l ~ d e ~ U n i d a d e s ~ d e ~ C o n s e r v a c ̧ a ̃ o ~ d a ~ N a t u r e z a ~}$ (SNUC).

${ }^{40}$ (BRASIL, 2007). Decreto ${ }^{\circ}$ 6040. Institui a Política Nacional de Desenvolvimento Sustentável dos Povos e Comunidades Tradicionais (PNPCT).
} 
porcos), comunidade de "fundo de pasto", geraizeiros (habitantes do sertão), pantaneiros (grifo nosso), caiçaras (pescadores do mar), ribeirinhos, seringueiros, castanheiros, quebradeiras de coco de babaçu, ciganos, dentre outras. Tais políticas estão sendo desenvolvidas pela Comissão Nacional de Desenvolvimento Sustentável dos Povos e Comunidades Tradicionais (CNPCT), objetivando promover o desenvolvimento sustentável, com ênfase no reconhecimento, fortalecimento e garantia dos direitos territoriais, sociais, ambientais, econômicos e culturais, além de respeito à valorização de identidade daquelas populações, às suas formas de organização e às suas instituições. (ZIMMERMANN, 2007).

O debate alusivo às populções tradicionais é pertinente ao amplo conceito sobre a relação homem-natureza e segundo Vianna (1996), principalmente no que se refere à separação homem-natureza, cuja ótica pressupõe que esta separação é a causa da destruição do ambiente pelas sociedades urbano-industriais. Isto difere da visão, quando se trata da afinidade entre "populações tradicionais" e natureza, a qual é, normalmente, aceita como "harmônica". Segundo a autora, esta idéia é revestida de pouca clareza conceitual e referencial, incorrendo em alguns problemas. Em primeiro, porque se a natureza é uma representação dada culturalmente, esta será sempre um fenômeno de ordem social, e em segundo lugar, porque o que diferencia as sociedades urbano-industriais das tradicionais não são suas relações com a natureza, mas sim que estas sociedades têm necessidades e condições de explorações diferentes, além da representação de natureza diferente.

Por um longo período, "tradição" era uma palavra problemática para pesquisadores em antropologia, porque denotava as atitudes do século XIX, do simples, selvagem e estático. Por essa razão, alguns estudiosos favoreceram o termo "Indigenous Knowledge" (WARREN, 2004, p. 4), como um "knowledge - practice- belief complex", uma visão de mundo ou cosmologia que inclui concepções básicas pertencentes à religião e a ética, estruturando observações que produzem conhecimento e entendimentos (BERKES; COLDING; FOLKE, 
2000). Nesta pesquisa, optou-se por tratar o conhecimento dos boiadeiros apenas como conhecimento tradicional.

Conhecimento tradicional pode ser definido como o saber e o saber-fazer, a respeito do mundo natural e sobrenatural, gerados no âmbito da sociedade não urbano/industrial e transmitido oralmente de geração em geração. Para muitas dessas sociedades, sobretudo as indígenas, existe uma interligação orgânica entre o mundo natural, o sobrenatural e a organização social. (DIEGUES, 2000, p. 30)

Considera-se que o conhecimento de populações tradicionais é transmitido por comunicação oral, imitação das práticas, habilidades técnicas, conjunto de conhecimentos racionais, crenças e normas, ao mesmo tempo, admite-se que inovações tecnológicas possibilitem novos acessos, como é o caso da comunicação a longa distância (CLAVAL, 2001).

Levando em consideração a complexidade deste tema referente às sociedades humanas e a natureza, buscou-se uma definição apoiada nos traços culturais que capaz de distinguir os boiadeiros como um seguimento dos modos de vida da tradição. Estes fazem parte de grupos humanos que reproduzem historicamente seu modo de vida, de forma mais ou menos isolada, com base na cooperação social e relações próprias com a natureza, desenvolvendo modos particulares de existência, adaptados a nichos ecológicos específicos. Uma das características marcantes destas populações é a auto-identificação ou identificação pelos outros de se pertencer a uma cultura distinta das outras. (ARRUDA; DIEGUES, 2001). Destarte, com o apoio em Claval (1999), é possível afirmar que a cultura dos boiadeiros designa o conjunto de práticas, de conhecimento, de atitudes e de idéias que cada indivíduo recebe, interioriza, modifica ou elabora no decorrer de sua existência.

Neste sentido para o estudo sobre os boiadeiros do pantanal, optou-se por adotar o conceito de populações tradicionais, pois apesar deste termo generalizar uma grande sociodiversidade e práticas sociais distintas, ele tem sido amplamente utilizado na literatura e na legislação brasileira. 


\subsection{Trajetória Metodológica}

A trajetória metodológica se justifica pelo modo como os dados foram levantados e construídos os resultados e sua análise. Trata-se de um caminho a ser traçado mais do que uma metodologia pronta a ser aplicada.

Durante a trajetória de conhecimento do fenômeno ${ }^{41}$ foi exposto o mundo-vida da pesquisadora e posteriormente uma reflexão sobre conceitos e contextualizações pertinentes ao estudo.

Nesta pesquisa compreende-se de que só há fenômeno enquanto houver um sujeito no qual ele se situa, vivenciando-o (BICUDO; MARTINS, 1989). Por esse motivo, foram elaboradas interrogações direcionadas àqueles que vivenciam o fenômeno, ou seja, aos boiadeiros, especialmente, mas também aos atores sociais que estão envolvidos com as Comitivas, como é o caso de peões e fazendeiros.

As interrogações iniciais foram: Quem são os boiadeiros ou peões de Comitiva? O que é uma Comitiva de boiadeiros? De onde vem? Para onde vão? Como organizam e interpretam o espaço e os lugares que experienciam? Como fazem a leitura da paisagem pantaneira? Como se orientam nas estradas boiadeiras? Quais diferenças entre as viagens durante as estações da seca e da cheia?

Diferentemente da estrutura de pesquisa por hipóteses que buscam aceitar ou rejeitar pré-conceitos, a interrogação surge de um pensar interior, onde a preocupação é situar o fenômeno buscando sua compreensão. Não se formula hipótese sobre o que se busca, apenas procura-se ver o fenômeno tal como o mesmo se mostra em termos de significados relacionais. É o momento em que o pesquisador dirige sua atenção para o que quer saber,

\footnotetext{
${ }^{41}$ A origem da palavra fenômeno vem da expressão grega fainomenon e deriva-se do verbo fainestai que quer dizer mostrar-se a sim mesmo. Fainestai é uma forma reduzida que provém de faino, que significa trazer a luz do dia. Ou seja, para este trabalho, a idéia de fenômeno, quer dizer aquilo que ser manifesta e que pode ser trazido à luz (MARTINS; BICUDO, 1989).
} 
buscando-se alcançar uma intersubjetividade entre o pesquisador e os sujeitos da pesquisa. (BICUDO; MARTINS, 1989).

Dessa forma, caminhou-se para o objeto de estudo através da intencionalidade do sujeito, atribuindo significados a esta estrutura da consciência e procurando descobrir a realidade investigada tal como experienciada pelo sujeito, exposta em suas descrições. Nelas estão as essências do que se busca conhecer.

O Mundo não é um objeto do qual possuo comigo a lei de constituição; ele é o meio natural e o campo de todos os meus pensamentos e de todas as minhas percepções explícitas. A verdade não 'habita' apenas o 'homem interior', o homem está no mundo, é no mundo que ele se conhece. (MERLEAU- PONTY, 1971, p. 6)

É fundamental esclarecer que trata-se de uma pesquisa qualitativa, o que não implica em falta de rigor, mas o que ela exige é outro tipo de rigor; o qual deve passar, inclusive, pela domação do verbo, pela geração discursiva de um texto exato que, na medida do possível, tenha obedecido às exigências do discursante e dos contextos. (MARQUES, 2000).

Concebe-se que a pesquisa qualitativa é basicamente descritiva (grifo nosso) (BICUDO; MARTINS, op. cit. p. 41), o que consiste em:

(...) anotar o significado do que as ações sociais particulares têm para os atores cujas ações elas são e afirmar, tão explicitamente quanto nos for possivel, o que o conhecimento assim atingido demonstra sobre a sociedade na qual é encontrado e, além disso, sobre a vida social como tal. Nossa dupla tarefa é descobrir as estruturas conceptuais que informam os atos dos nossos sujeitos, o "dito" no discurso social, e construir um sistema de análise em cujos termos o que o que é genérico a essas estruturas, o que pertence a elas porque são o que são, se destacam contra outros determinantes do comportamento humano. (GEERTZ, 1989, p. 38).

O mérito da descrição não é a exatidão ou se é verdadeira ou falsa, mas sim a capacidade de criar e facilitar para o leitor (ou ouvinte) uma reprodução tão clara quanto possível do que está sendo descrito. (BICUDO; MARTINS, op. cit, p. 46). É importante apontar que estas descrições são contextualizadas e devem ser tratadas interpretativamente. Procurou-se fazer uma "descrição densa", interpretando o fluxo do discurso social e tentando 
salvar o "dito" num tal discurso da sua possibilidade de extinguir-se e fixá-lo em formas pesquisáveis. (GEERTZ, 1989, p. 31) ${ }^{42}$.

Os dados desta pesquisa também foram obtidos por meio de levantamentos bibliográficos, mas devido à abordagem escolhida e à escassez de material disponível sobre o tema pesquisado, os dados vieram, principalmente, da coleta de relatos, de entrevistas com interlocutores locais, suas histórias de vida e pelo acompanhamento presencial de Comitivas de viagem. Estes dados primários constituem a descrição do cotidiano dos boiadeiros, associado às leituras das paisagens do Pantanal.

Para registros dos mesmos foram utilizados diários de campo, impressões subjetivas, gravador, GPS, máquina fotográfica e mapa das fazendas do Pantanal- EMBRAPA (1996). ${ }^{43}$

A pesquisa foi realizada no Pantanal Sul-Mato-Grossense, mais especificamente nos pantanais de Miranda, Aquidauana, Nabileque, Abobral e Nhecolândia. Estas são as regiões de abrangência da pesquisa (Mapa 1), as localizações mais específicas fazem parte dos resultados e estão indicadas no decorrer dos capítulos, já que expressa também os roteiros das Comitivas $^{44}$.

Foram realizadas visitas às bibliotecas, primariamente da USP - Universidade de São Paulo, UFMS - Universidade Estadual do Mato Grosso do Sul, e UNIDERP - Universidade para o Desenvolvimento do Estado da Região do Pantanal, além de buscas via internet e periódicos acerca do assunto. A partir desses estudos, foram realizados contatos com alguns atores chaves para aprimoramento do material recolhido. A intenção foi obter dados junto a

\footnotetext{
${ }^{42}$ Entende-se que neste trabalho, há uma busca para o aprofundamento nas características apontadas por estes autores, mas seria pretensioso dizer que isto foi plenamente alcançado.

43 EMBRAPA PANTANAL. Fazendas do pantanal. Corumbá: Ministério da Agricultura e Abastecimento, [1996]. Escala 1:750.000. Este mapa foi modificado para mostrar a delimitação da área de estudo (Mapa 1).

${ }^{44}$ Ver também Tabela 1- Acompanhamento de comitivas, p. 65, e Apêndice B - Mapas.
} 
instituições relacionadas ao desenvolvimento, cultura e tradições no Pantanal, como é o caso da Fundação Boticário, Instituto Parque do Pantanal, entre outros. ${ }^{45}$

Os instrumentos de pesquisa de campo utilizados foram alguns dos empregados em metodologia qualitativa: entrevista, história de vida e observação participante.

A entrevista foi um instrumento utilizado com o objetivo de conseguir descrições tão detalhadas quanto possível das preocupações do entrevistado.

Não é tal objetivo, produzir estímulos pré-categorizados para respostas comportamentais. As descrições ingênuas situadas, sobre o mundo-vida do respondente, obtidas através da entrevista, são, então, consideradas de importância primária para a compreensão do sujeito. (BICUDO; MARTINS, 1989, p. 54 ).

Optou-se pela entrevista devido à maior flexibilidade do que a aplicação de questionários. Desse modo, foram parcialmente estruturadas, sendo feitas interrogações gerais, já citadas acima, tais como: Quem são? De onde vêm? Para onde vão? Outras interrogações foram redefinidas conforme o desenvolvimento da entrevista e de acordo com o tema da pesquisa, focalizado no modo de vida e leituras das paisagens pelos boiadeiros ${ }^{46}$.

Antes de cada entrevista foi informado aos colaboradores sobre as intenções da pesquisa. Inicialmente foram feitas perguntas voltadas para suas histórias de vida, o que já contribui tanto para a compreensão das vivências pessoais como as relacionadas ao trabalho. Dessa forma, aos poucos foi se adentrando ao cotidiano e ao modo de trabalho e então, sobre as leituras das paisagens pantaneiras.

Por intermédio do recurso da história de vida, entende-se que é possível captar o processo de memória ${ }^{47}$ e de reflexão crítica de um ser humano sobre suas vivências tidas em

\footnotetext{
${ }^{45}$ No primeiro ano de pesquisa foi dado prioridade à execução das disciplinas e estudo crítico da bibliografia, em relação às saídas a campo, devido à longa distância e duração das Comitivas de boiadeiros. Apesar disto, neste mesmo ano foram realizadas algumas entrevistas e houve participações em três Comitivas, distribuídas de acordo com o ciclo das águas - cheia, vazante e seca. Era suposta a participação ainda em outras Comitivas, mas devido a problemas de saúde, não foi mais possível acompanhá-las, tendo que suspender estas atividades.

${ }^{46}$ Apesar da existência de um roteiro de entrevista (Apêndice C) as perguntas foram sendo feitas de acordo com o contexto apresentado pelo entrevistado.

47 Por memória entende-se como aquela que está ligada ao hábito, mais imediata, automática ou como memória independente de hábitos, sendo lembranças isoladas. A memória permite a relação do corpo presente com o
} 
condições sociais altamente específicas. É uma técnica capaz de constatar valores, expectativas, ideais de vida, ponderações, frustrações e sofrimento face aos vários processos sociais vivenciados pelos colaboradores. E quanto mais o colaborador é deixado falar por si mesmo, mais nos deparamos com a sua própria visão de mundo, bem como das transformações nele contidas. (VIERTLER, 2002).

Foram feitas três entrevistas, com interlocutores locais (Tabela 2), onde se procurou pessoas disponíveis para conversar e que trabalhassem ou tivessem tido experiência em Comitivas. As entrevistas foram gravadas e transcritas (Apêndice C- Entrevistas), com exceção da entrevista realizada com o Sr. Rolon. Esta, apesar de não ter sido transcrita contribuiu para compreensão do tema de estudo, pois o Sr. Rolon prestava serviço para Comitivas de boiadeiros, ajudando na travessia de boiadas no Rio Taquari (Porto Rolon).

Durante o acompanhamento das Comitivas foi utilizada a estratégia da observação participante (Fig.10 e 11), onde se entende que:

(...) o pesquisador entrega-se à rotina e a participação nas várias atividades de interesse dos pesquisados. Os nós de incompreensão percebidos pelo pesquisador pouco a pouco vão se dissolvendo por um complexo de "aprender fazendo", permitindo-lhe compreender com mais profundidade sentidos até então não detectados de referenciais culturais dos seus observados. (Ibid, p. 6).

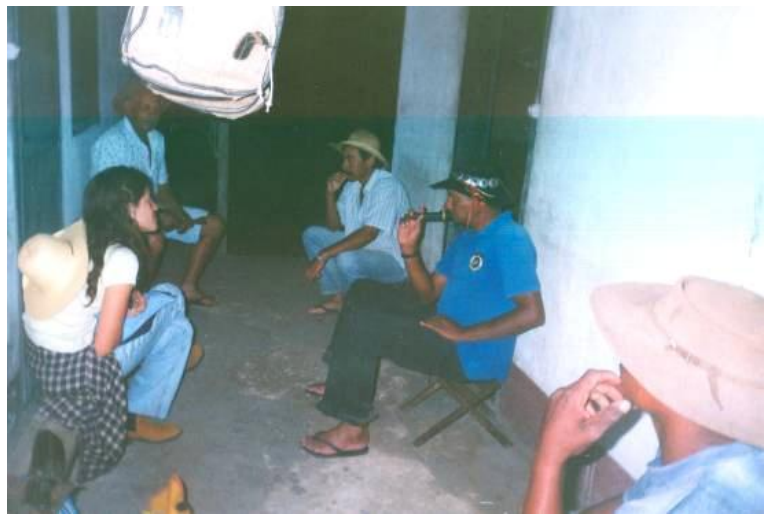

Fig. 10 - Observação participante (primeira comitiva). ̀̀ minha esquerda, os boiadeiros Vô Alfredo, Ramon, Morcego e Zumba.
Foram acompanhadas três Comitivas de boiadeiros (Tabela 1). A primeira partiu da fazenda Estância Caiman em 2005, com duração de cerca de dez dias e o objetivo de transportar 549 vacas para outra fazenda do mesmo proprietário. A permissão foi obtida pelo gerente da fazenda, pois naquele 
momento a pesquisadora trabalhava como guia na pousada Caiman, situada no mesmo local. Não houve conhecimento prévio dos boiadeiros da Comitiva, isto se deu apenas na noite anterior a viagem. Uma situação facilitadora foi que a colega de trabalho, Bete Leite, também quis acompanhar a viagem e apesar de ser a primeira vez que viajava desta forma, por ser natural da região de estudo e ter família vivendo nesta fazenda há mais de uma geração, já conhecia alguns dos boiadeiros que viajariam conosco. Esta Comitiva foi acompanhada pela pesquisadora durante quatro dias.

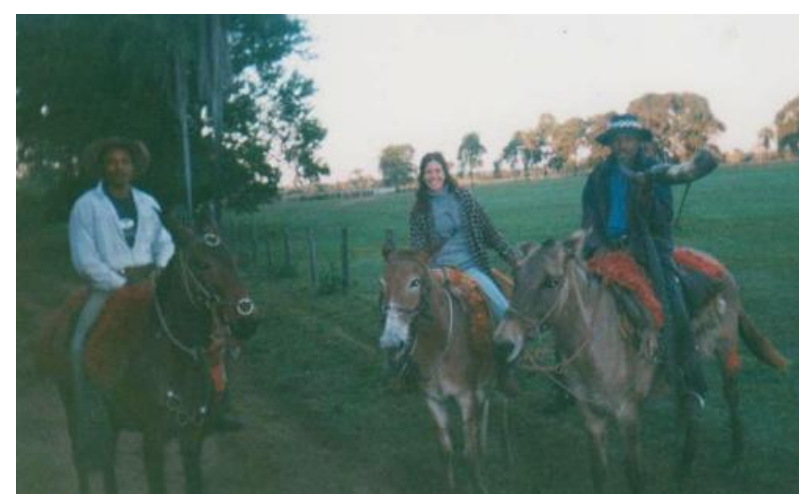

Fig. 11- À minha esquerda, Zumba e à direita Morcego, com berrante. Primeira Comitiva.

A segunda Comitiva ocorreu em 2006, iniciou-se na Fazenda Alvorada, com duração e acompanhamento de 3 dias. A participação na mesma também foi facilitada pelo trabalho como guia, nesse caso, na Pousada Xaraés (Corumbá-MS), com a permissão de um dos proprietários da mesma, também proprietário da fazenda citada. O intuito era o transporte de 300 novilhas que haviam sido compradas para manejo de engorda.

A última Comitiva foi possibilitada por meio do contato com o Prof. Erom Brum ${ }^{48}$, que gentilmente orientou-me a conversar com Dona Edite Araújo Cardoso. Há cerca de 15 anos, esta senhora organiza Comitivas como prestadora de serviço, principalmente, para a Fazenda Nove de Ouro. Em 2007, após receber-me em sua própria casa, permitiu-me que acompanhasse uma destas viagens. Então, no mesmo ano, ficou combinado o encontro na fazenda Nossa Senhora do Carmo, pela pesquisadora morar nesta fazenda e também fazer parte do roteiro ${ }^{49}$ de uma das Comitivas. Foram quatro dias de acompanhamento presencial, porém a viagem dos boiadeiros teve duração de mais de um mês. $\mathrm{O}$ intuito era o transporte pela venda de 1.008 vacas para manejo de engorda.

\footnotetext{
${ }^{48}$ O professor era atuante no Programa de Pós Graduação em Meio Ambiente e Desenvolvimento regional (linha de pesquisa: sociedade, cultura e natureza)/ UNIDERP.

${ }^{49}$ Há um ponto de parada de Comitiva (pouso ou almoço), localizado nesta fazenda.
} 
Tabela 1 - Acompanhamento de Comitivas

\begin{tabular}{|c|c|c|c|}
\hline $\begin{array}{l}\text { VIAGEM/ } \\
\text { DATA } \\
\end{array}$ & DADOS $^{50}$ & $\begin{array}{c}\text { ROTEIRO } \\
\text { (por ponto de pouso) } \\
\end{array}$ & $\begin{array}{c}\text { SUB-REGIÕES } \\
\text { PANTANAL }\end{array}$ \\
\hline $\begin{array}{l}\mathbf{1}^{\circ} \text { Comitiva } \\
\text { Caiman } \\
\text { (Març. 2005) }\end{array}$ & $\begin{array}{l}4 \text { dias } / 48 \mathrm{~km} \\
549 \text { vacas } \\
\text { (manejo para } \\
\text { pasto plantado) }\end{array}$ & $\begin{array}{l}\text { Fazenda Estância Caiman - Retiro } \\
\text { Santa Vóia (Miranda) à Fazenda Costa } \\
\text { Rica (Aquidauana) }\end{array}$ & $\begin{array}{l}\text { Miranda à } \\
\text { Aquidauana }\end{array}$ \\
\hline $\begin{array}{l}2^{\circ} \text { Comitiva } \\
\text { Nossa Sra } \\
\text { do Carmo } \\
\text { (Març. 2006) }\end{array}$ & $\begin{array}{l}3 \text { dias/ } 70 \mathrm{~km} \\
300 \text { bezerras } \\
\text { (compra para } \\
\text { engorda) }\end{array}$ & $\begin{array}{l}\text { Fazenda Alvorada, Fazenda Mutum, } \\
\text { Morro do Azeite, Passo do Lontra, } \\
\text { Fazenda Nossa Sra. do Carmo. } \\
\text { (Corumbá), }\end{array}$ & $\begin{array}{l}\text { Nabileque ao } \\
\text { Abobral }\end{array}$ \\
\hline $\begin{array}{l}3^{\circ} \text { Comitiva } \\
\text { Nove de } \\
\text { ouro } \\
\text { (Julh. 2007) }\end{array}$ & $\begin{array}{lr}4 \text { dias/36 } \mathrm{km} \\
1.008 & \text { vacas } \\
\text { (venda } & \text { para } \\
\text { engorda) } & \\
\end{array}$ & $\begin{array}{l}\text { Fazendas: Nossa Sra. Carmo; São } \\
\text { Carlos, Buriti, Santa Eugênia e Santo } \\
\text { Onofre. (Corumbá) }\end{array}$ & $\begin{array}{l}\text { Abobral ao } \\
\text { Nhecolândia }\end{array}$ \\
\hline \multicolumn{4}{|c|}{$\begin{array}{l}\text { * Os roteiros das duas úlltimas Comitivas acompanhadas também foram desenhados pela pesquisadora. } \\
\text { (Apêndice B - Mapas desenhados). } \\
\text { * As Comitivas acompanhadas estão citadas no decorrer da dissertação pela ordem da data de participação da } \\
\text { pesquisadora (primeira, segunda e terceira) }\end{array}$} \\
\hline
\end{tabular}

Uma observação pertinente a este estudo é o que se refere ao meio de transporte utilizado pela pesquisadora durante o acompanhamento das Comitivas. Gostosa/mula (Fig. 11), Sapo/ burro (Fig. 12) e Jamanta/égua, foram os animais montados durante as respectivas viagens e notou-se que os mesmos foram cuidadosamente escolhidos pelos Condutores por serem os mais mansos da tropa.

Além disto, acredita-se que por estar familiarizada a montar cavalos, a viagem não significou um fator problema, e ao contrário, propiciou uma maior aproximação ao mundo dos boiadeiros, tanto na forma de conhecer, relacionar-se

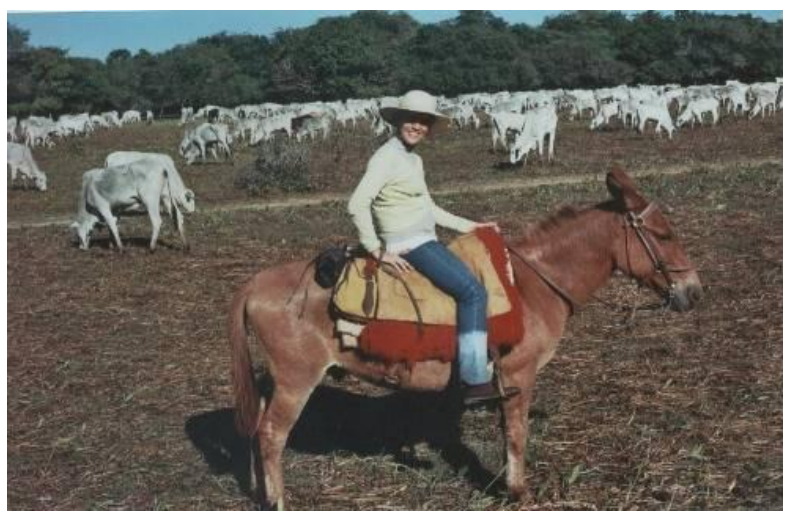

Fig. 12 - Sapo, minha montaria. Terceira Comitiva. com o mesmo, como com o animal e o mundo, ver e sentir também através de uma perspectiva diferente.

\footnotetext{
${ }^{50}$ A quilometragem percorrida é um valor aproximado. Foram considerados 12 quilômetros por dia, o que significa a média relatada pelos boiadeiros, denominada como 1 marcha. Apenas a segunda Comitiva não segue está lógica, pois como o número de reses era menor e a viagem de curta duração, a distância percorrida por dia pode ser maior.
} 


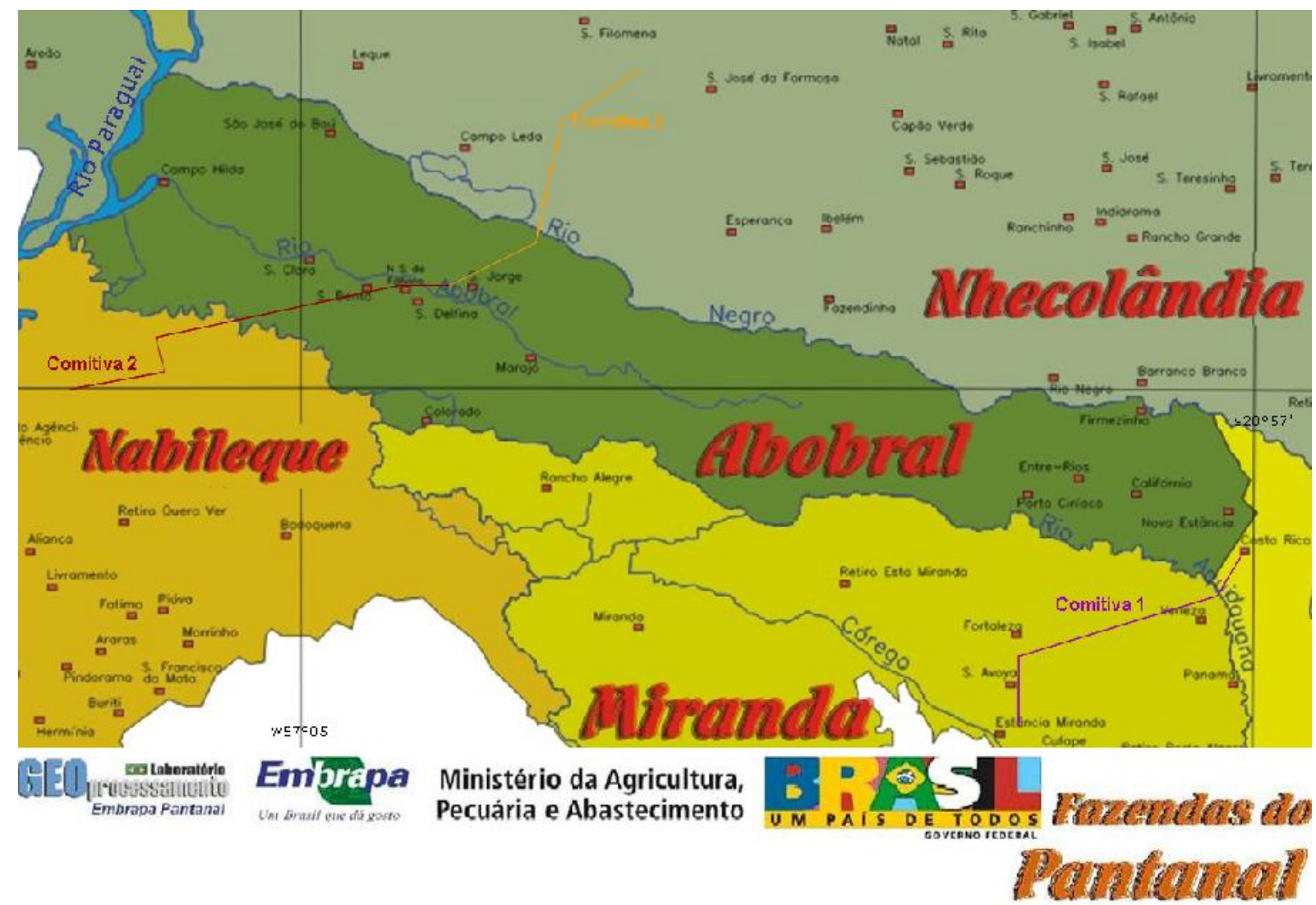

Mapa 2- Mapa ilustrativo: Fazendas Pantanal- MS e roteiros das três Comitivas acompanhadas. Fonte: EMBRAPA (modificado).

Outro importante recurso utilizado para colher os relatos dos boiadeiros sobre o pantanal foi o método descritivo, baseado na leitura da paisagem, pois se compreende que os caminhos das comitivas são lidos a partir de marcos referenciais. Para tal, compreende-se que assim como na escrita de um texto ocorre uma organização a partir da psicogênese da escrita (FERRERO, 1999) ${ }^{51}$, nas paisagens há marcos referenciais que podem ser considerados como signos de uma leitura da paisagem. A paisagem é como um texto que contém sistemas simbólicos e códigos que podem ser apreendidos e lidos em diferentes momentos, na medida

\footnotetext{
${ }^{51}$ Em seu estudo sobre a psicogênese da escrita, Ferreiro (1999, p. 27) procurou observar e descrever como se realiza a construção da linguagem escrita na criança, como um processo no qual se constitui um conhecimento que transcorre insuspeitados caminhos. A autora afirma que a criança inicia o seu processo de alfabetização muito antes de entrar para a escola e considera-a como ser capaz, mesmo desde muito pequena, de criar hipóteses, de testá-las e de criar sistemas interpretativos na busca de compreender o universo que a cerca. Desta forma, chamou a atenção para a complexidade da escrita como um sistema de representações e inovou ao assumir a alfabetização em uma abordagem mais ampla, explicando-a também pelas variáveis sociais, culturais, políticas e psicolingüísticas.
} 
em que há apropriação de uma linguagem do espaço (FURLAN, 2009) ${ }^{52}$. Esta é uma importante reflexão neste estudo, já que existe um esforço em ler como os boiadeiros estruturam estes sistemas simbólicos e, dentro dessa leitura, visualizar algumas das várias interpretações que os mesmos possuem.

Podemos acrescentar que esta descrição da paisagem seja não de uma cena individual, mas como um somatório de características gerais, assim como propõe Sauer (1925). São paisagens que se revelam através das lembranças, memórias espacializadas pelos sujeitos que a vivenciam, além das de observações da pesquisadora.

Neste sentido, o mapa mental foi um instrumento utilizado para a compreensão sobre as leituras das paisagens. Para tal, adotou-se a definição de Archela; Gratão; Trostdorf ( 2004, p. 127)

Os mapas mentais são imagens espaciais que as pessoas têm de
lugares conhecidos, direta ou indiretamente. As representações
espaciais mentais podem ser do espaço vivido no cotidiano, como por
exemplo, os lugares construídos do presente ou do passado; de
localidades espaciais distantes, ou ainda, formadas a partir de
acontecimentos sociais, culturais, históricos e econômicos, divulgados nos
meios de comunicação.

A partir de mapas mentais, que revelam formas de experiêcia vivida, buscou-se conhecer os valores, os sentidos dados aos lugares, e assim, as paisagens. Foram elaborados mapas mentais de alguns roteiros das Comitivas de boiadeiros, tanto de trajetos percorridos pela pesquisadora, quanto àqueles relatados pelos entrevistados (Apêndice B). Estes últimos foram desenhados pela pesquisadora, de acordo com a orientação simultânea dada pelos entrevistados.

\footnotetext{
${ }^{52}$ FURLAN, S. Â. Informação fornecida na correção deste texto, durante orientação em 20 de agosto. 2009.
} 


\subsubsection{Os Colaboradores}

Durante o acompanhamento das Comitivas procurei não concentrar atenção em uma só pessoa, pois há diversidade nas funções de trabalho dos boiadeiros. Uma maior atenção foi dada somente a aqueles mais experientes, mais velhos, normalmente os líderes do grupo.

Assim ocorreu com o Vô Alfredo ${ }^{53}$ (Fig. 13), 78 anos, apesar de não mais exercer o ofício de Condutor de boiada, ainda acompanhava seu filho Ramon Miranda, nas Comitivas, a quem ensinou o mesmo o ofício.

No acompanhamento da primeira Comitiva este senhor estava presente e percebeu-se que sua forma de conduzir boiadas continha um profundo conhecimento aliado a técnica de trabalho. Infelizmente não houve tempo hábil

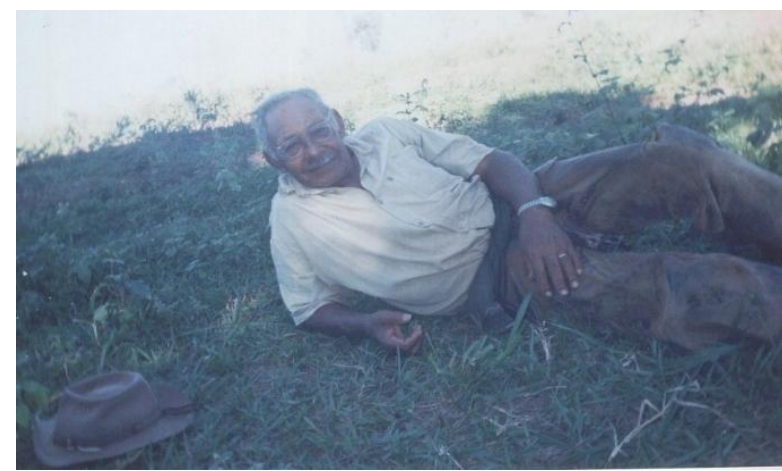

Fig. 13 - Sr. Alfredo Miranda, pai de Ramon Miranda. Ponto de almoço. Primeira Comitiva. de entrevistá-lo, pois ele faleceu logo após a realização da primeira Comitiva acompanhada. Segundo relato de seu filho Ramon, isto aconteceu durante uma viagem de Comitiva, acompanhando-o. Foi uma morte natural, ocorrida enquanto descansava em um ponto de parada para almoço.

Outra condição facilitadora para compreensão do tema de estudo foi proporcionada

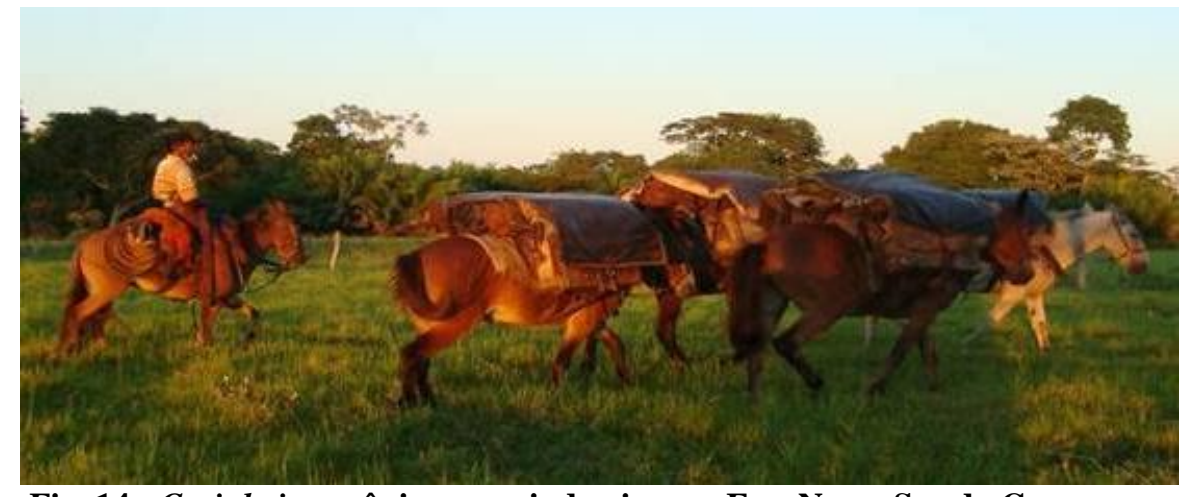

Fig. 14 - Cozinheiro anônimo seguindo viagem. Faz. Nossa Sra do Carmo. pelos Cozinheiros

das Comitivas (Fig.

14), pois como

viajam quase

sempre sozinhos

precisam conhecer

\footnotetext{
${ }^{53}$ Logo no primeiro dia de viagem ele pediu, carinhosamente, para que o chamasse de Vô Alfredo e não Senhor Alfredo.
} 
muito bem os roteiros. Além disto, já que chegam primeiro e permanecerem mais tempo nos pontos de parada, é propício seus diálogos com moradores das fazendas e assim, costumam estar bem informados. Por este motivo também, durante o preparo das refeições pelo Cozinheiro, percebeu-se ser oportuno coletar dados, desenvolver uma conversa mais tranqüila e aprofundada facilitando a aproximação da pesquisadora. Estes momentos ocorreram, principalmente, durante a primeira Comitiva, com o Cozinheiro Romário, terceira Comitiva, com o Cozinheiro Dourado e durante a entrevista com o Cozinheiro Biguá. A entrevista com este último colaborador citado foi possível ocorrer, quando através de informações fornecidas pela comunidade local, se soube que o mesmo era um Cozinheiro experiente e estava preparando o almoço em um ponto de pouso com fácil acesso pela pesquisadora ${ }^{54}$.

Em vários momentos houve a colaboração do Sr. José Oscar Santos Silva (Fig. 15), 52 anos, capataz da Fazenda Nossa Senhora do Carmo. Este senhor, conhecido como Seu Zé

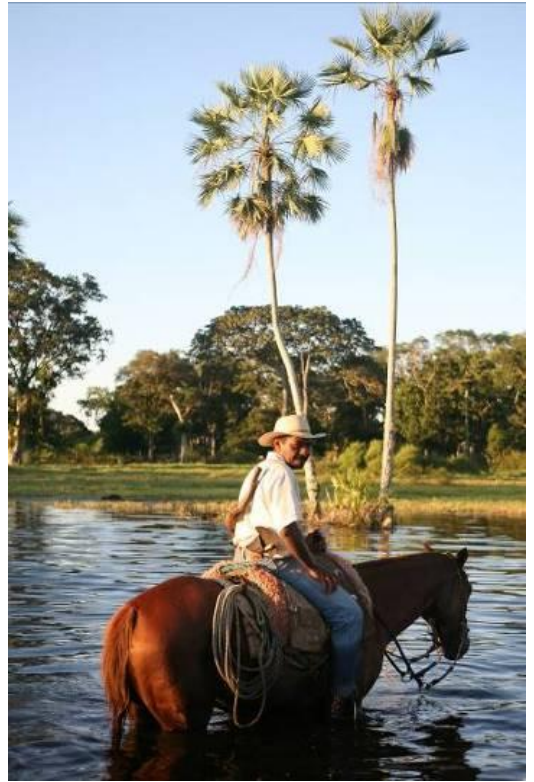

Fig. 15 - Sr. Zé Preto trabalhando na estação da cheia. Fonte: Pousada Xaraés.
Preto, é natural da região da Nhecolândia (sub-região do Pantanal), viajou em Comitivas e sempre morou no Pantanal. Seu pai também era capataz de fazenda na região. Pela experiência que possui e pela pesquisadora morar na mesma fazenda, já o conhecendo a cerca de seis anos, ele foi considerado como consultor ${ }^{55}$ desta pesquisa.

Alguns pecuaristas e/ou compradores de gado também foram consultados, sendo citados apenas como fontes orais.

O entrevistado Juarez Rodrigues da Silva, 42 anos, (Fig. 17) , foi considerado como colaborador chave. Pela

\footnotetext{
${ }^{54}$ Por problemas de saúde da pesquisadora e para obtenção de dados, teve que se recorrer a opções com maior facilidade de acesso, tal como proximidade dos pousos do seu local de moradia e a proximidade a certas fontes orais, como o Seu Zé Preto.

${ }_{55}$ Aquele a quem recorri, muitas vezes, para tirar dúvidas.
} 
pesquisadora conhecê-lo há cerca de cinco anos, serem grandes parceiros de trabalho como guias de ecoturismo e por ele ser desinibido para falar, a entrevista ficou muito clara, sendo sua contribuição primordial a esta pesquisa.

A entrevista com José Aparecido Francisco da Silva, 31 anos, conhecido com o apelido de Barriga (Fig. 16), também foi facilitada pela pesquisadora conhecê-lo a cerca de seis anos e terem trabalhado juntos como guias de ecoturismo. Apesar de ele ter tido poucas experiências em viagens de Comitivas, sua entrevista foi importante, porque além der ter nascido e crescido na região, conhece bem o trabalho e alguns dos roteiros percorridos pelos boiadeiros.

Foi perguntado aos colaboradores se suas imagens e citações poderiam ser incluídas nesta pesquisa. Todos aceitaram o pedido. Os entrevistados foram citados nesta dissertação pelo primeiro nome ou por seus apelidos, seguido do ano de suas respectivas entrevistas. Em alguns casos, os colaboradores não foram identificados, sendo que os que participaram das Comitivas, por vezes, foram citados apenas pelos apelidos ou através da função que desempenham, indicando a ordem da data de participação (primeira, segunda ou terceira Comitiva) ${ }^{56}$.

Foram vários os boiadeiros colaboradores, sem os quais esta pesquisa não poderia ter ocorrido. Por vezes, as contribuições vieram sem que houvesse a necessidade de exprimiremse em palavras, eram gestos, atitudes, olhares que possibilitaram a contrução da interpretação da pesquisadora. Abaixo, segue um quadro com outros protagonistas fotografados.

\footnotetext{
${ }^{56}$ Ver Tabela 1. Acompanhamento de comitivas, p. 65.
} 
Tabela 2 - Entrevistas

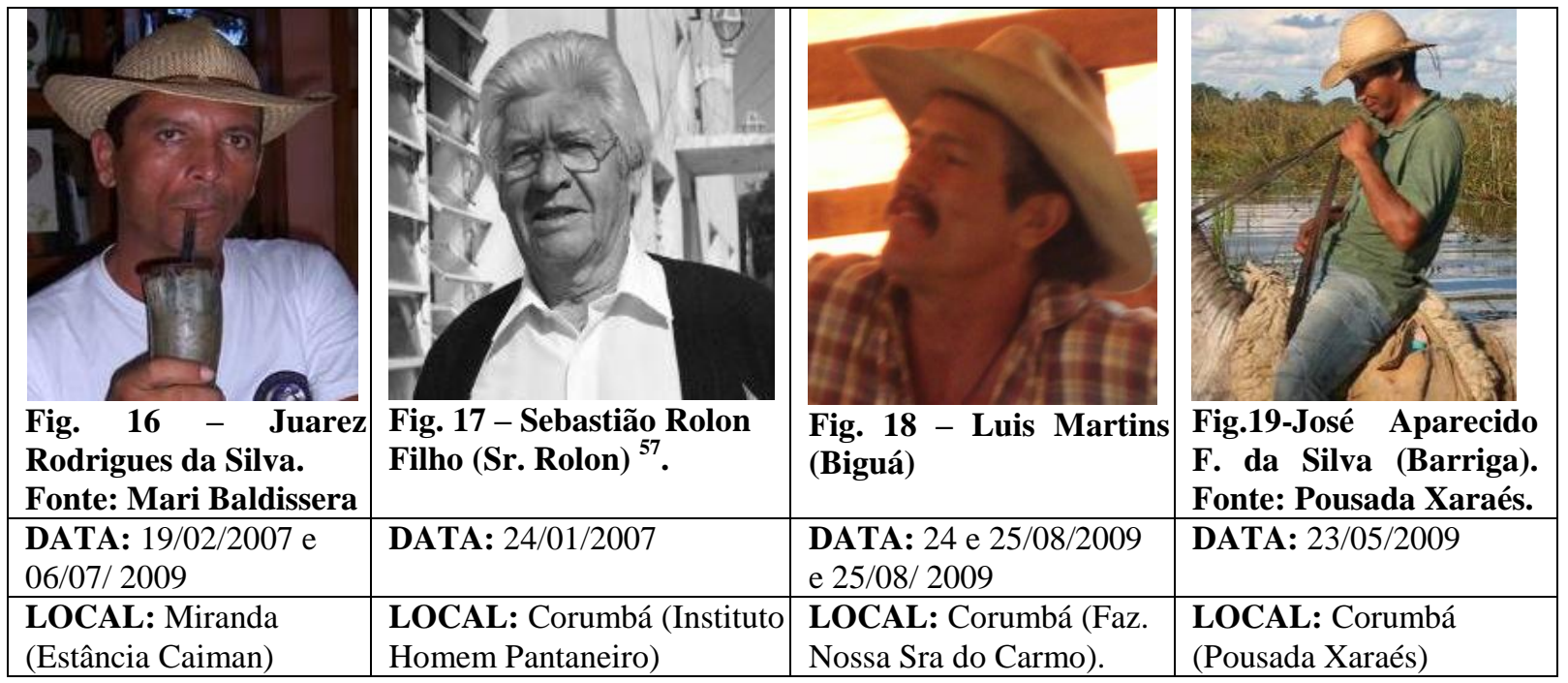

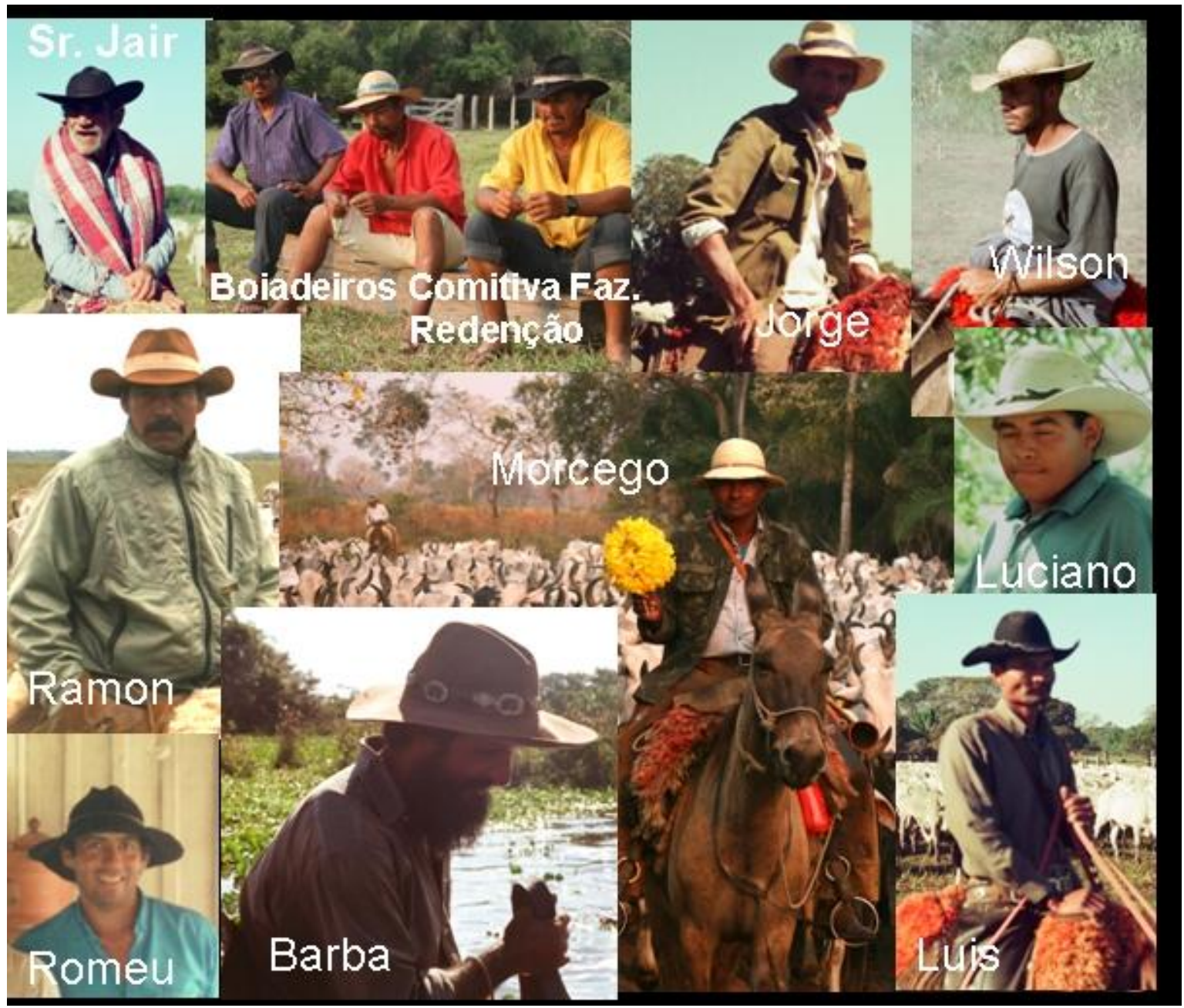

Fig. 20. Quadro Colaboradores.

\footnotetext{
${ }^{57}$ Não será transcrita, pois não trabalhou como boiadeiro. Era proprietário de uma fazenda de acesso ao local onde os boiadeiros atravessavam o rio Taquari. Deverão ser utilizados alguns trechos de sua entrevista.
} 


\subsubsection{Construção dos Resultados}

A construção da interpretação sobre o modo de vida dos boiadeiros e suas relações com a paisagem pantaneira está fundamentada na abordagem conceitual ${ }^{58}$ elaborada, principalmente, a partir dos dados empíricos.

De acordo com as interrogações nesta pesquisa estes dados foram selecionados em um estudo piloto buscando-se concentrar-se nos significados que os eventos significam para os sujeitos das pesquisas. Compreende-se que cada sujeito (colaborador), ao vivenciar um fenômeno, possui um discurso sobre esta experiência. (MARTINS; BICUDO, 1989). Os dados obtidos são as situações vividas que foram conscientemente tematizadas pelo mesmo, então os significados das suas vivências emergem do seu espaço vivido.

Além disto, deve-se considerar que a interpretação deste tema de estudo ocorre a partir de experiências partilhadas (SANDEVILLE, 2005), tanto entre os indivíduos, como entre indivíduos e a paisagem. Por um tempo, o pesquisador também se insere nestas experiências e interage, sendo que neste caso, já existia um relacionamento anterior da pesquisadora como o tema abordado.

Desta forma, foi feita uma análise de conteúdo concebida como uma "análise de significados" dos discursos coletados (BARDIN, 1995, p. 34), admitindo-se que quanto mais profunda, esta será menos completa. O comprometimento se dá buscando mantê-la tão estreitamente ligada quanto possível aos acontecimentos sociais e ocasiões concretas, e organizá-la de modo que as conexões conceituais e interpretações descritivas não sejam obscurecidas. (GEERTZ, 1989).

A preocupação está voltada, inicialmente, à subjetividade, mas embora as percepções sejam subjetivas para cada indivíduo, podem ocorrer recorrências comuns, seja em relação às

\footnotetext{
${ }^{58}$ Ver item 1.2, p. 46.
} 
percepções e imagens, seja em relação às condutas possíveis. (DEL RIO, 1999). Assim como estas convergências, podem ser identificadas divergências ou idiossincrasias, que constituem então, as unidades (recorte) escolhidas neste estudo. Neste sentido, de acordo com Bardin (1995), produziu-se um sistema de categorias de análise, relacionando os significados dos discursos obtidos (principalmente), a observação participante, as imagens de fotos e as pesquisas existentes sobre a área de estudo. Finalmente, estas categorias foram tematizadas, resultando nos Capítulos III, IV, V.

Após o estabelecimento destas temáticas identificou-se, nas entrevistas transcritas, os trechos mais significativos que poderiam ilustrá-las, procurando respeitar as peculiaridades da fala dos entrevistados. Estes recortes receberam uma maior atenção, no que se refere ao processo da transcrição e estão apresentados com os nomes dos entrevistados entre parênteses. As omissões de trechos estão simbolizadas por reticências entre parênteses e as inserções de esclarecimentos que não pertencem aos relatos localizam-se entre colchetes. (FONTANA, 2004)

Cabe ressaltar ainda, que Antropologia interpretativa é uma ciência concebida como “essencialmente contestável”, qualquer generalidade alcançada surge da delicadeza de suas distinções, não da amplidão das suas abstrações. A importância está em sua especificidade complexa, sua circunstancialidade e seu progresso mais marcado por um refinamento do debate, do que por uma perfeição de consenso. A vocação não é responder as nossas questões mais profundas, mas colocar à disposição as respostas que outros deram e assim incluí-las no registro de consultas do que o homem falou. (GEERTZ, 1989).

O mais importante é situar-nos (no universo imaginativo do grupo, no caso, dos boiadeiros). "Nós não compreendemos o povo (e não por não compreender o que eles falam entre si). Não podemos situar entre eles". Wittgenstein ${ }^{59}$ (1989 apud Ibid, p. 10, grifo do

\footnotetext{
${ }^{59}$ Wittgenstein, L. Philosophical investigations. Oxford: Blackwell publishing, 1953.
} 
autor). Isto quer dizer que é impossível nos tornarmos nativos ou copiá-los, o que se procura é conversar com eles, diferentemente de falar por eles. A descrição é feita em segunda ou terceira mão, quer dizer, são interpretações e não elas mesmas (GEERTZ, 1989, p. 31), o que se tem são impressões subjetivas. 


\section{CAPÍTULO 2. COMITIVA DE BOIADEIROS: MODO DE VIDA}

No conduzir de um gado, que é tarefa monótona, de horas inteiras, às vezes de dias inteiros, é no uso de canto $e$ recontos que o pantaneiro encontra o seu ser. Na troca de prosa ou de montada, ele sonha por cima das cercas. É mesmo um trabalho na larga, onde o pantaneiro pode inventar, transcender, desorbitar pela imaginação.

Porque a maneira de reduzir o isolado que somos dentro de nós mesmos, rodeados de distâncias e lembranças, é botando enchimento nas palavras. É botando apelidos, contando lorotas. É, enfim, através das vadias palavras, ir alargando os nossos limites.

Certo é que o pantaneiro vence o seu estar isolado e o seu pequeno mundo de conhecimentos, e o seu parco vocabulário, recorrendo às imagens e brincadeiras.

Assim, o peão de culatra é bago-de-porco, porque vem por detrás. Pessoa grisalha é cabeça de paina. Cavalo corredor é estufador de blusa. Etc. Etc. (BARROS, 1990, p. 240)

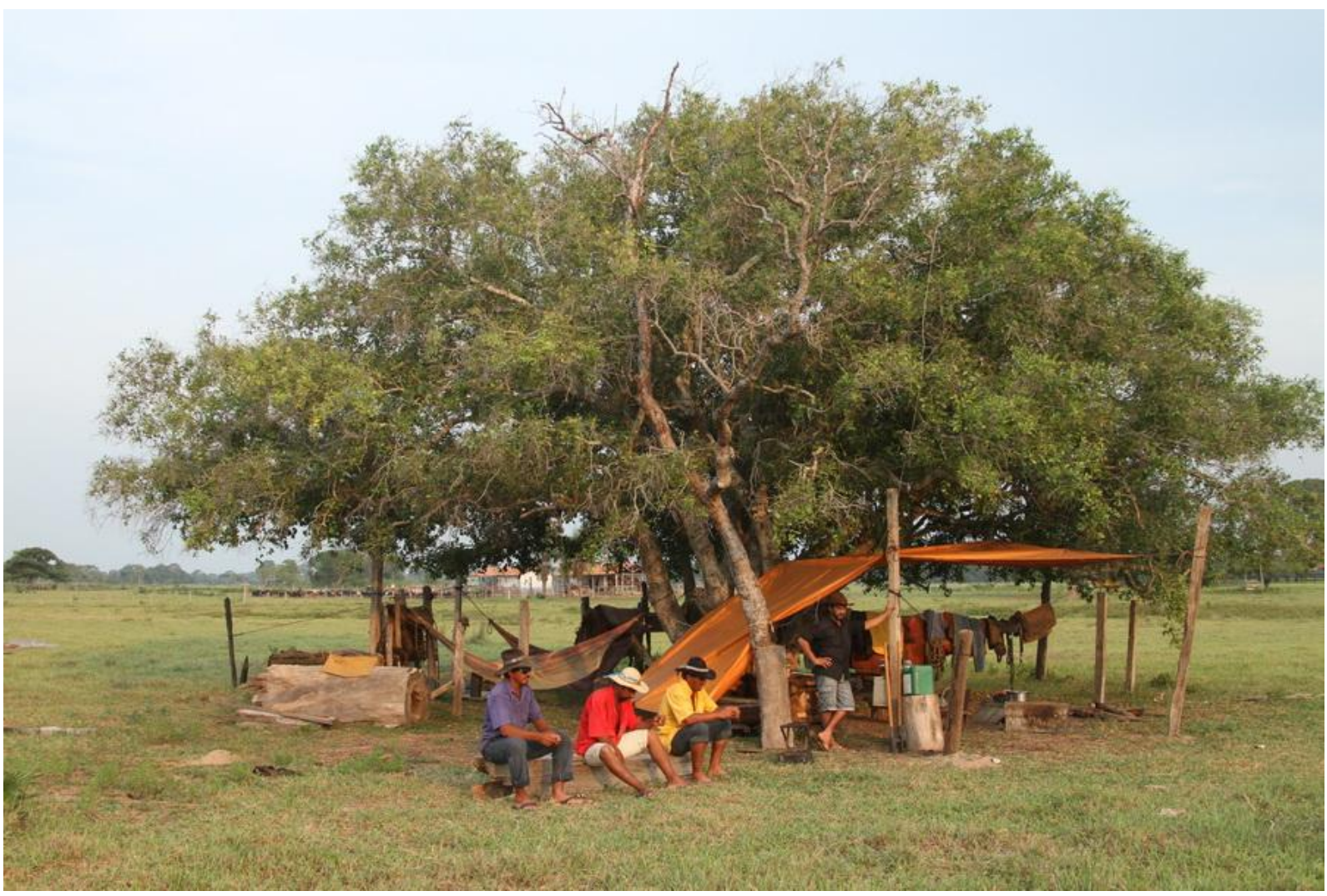

Fig. 21 - Comitiva da Fazenda Redenção no ponto de pouso da Fazenda Nossa Senhora do Carmo. Fonte: Csaba Gödény. 
O tema do presente capítulo refere-se ao modo de vida dos boiadeiros. Primeiramente, em "Viajantes do estradão" buscou-se traçar o tipo cultural do boiadeiro e, em seguida, no subtítulo: "Na batida das Comitivas de boiadeiros" apresenta-se a forma como ocorrem as viagens nas Comitivas. Por fim, em "Puxando a boiada" buscou-se retratar o cotidiano do boiadeiro, considerando os diferentes ofícios que podem executar para condução do gado.

\subsection{Viajantes do estradão}

Com raras exceções ${ }^{60}$, observou-se que o boiadeiro do Pantanal é, em princípio, um pantaneiro. Segundo Banducci Junior (1995), pantaneiros são pessoas que residem e/ou trabalham nas fazendas do pantanal, em caráter permanente ou transitório e que se autodenominam desta forma. A categoria abrange indivíduos que compartilham hábitos e valores da cultura local e se submetem às regras de convívio social ${ }^{61}$, sendo constituída, principalmente, pelos vaqueiros.

Apesar desta definição não abarcar os demais grupos sociais, é esta a visão utilizada na presente pesquisa, em que se pretendeu traçar o perfil do boiadeiro dentro do contexto de vaqueiro pantaneiro, mas com algumas diferenciações mais específicas.

Vários autores (PROENÇA, 1997; BANDUCCI JUNIOR, 1995; RONDON, 1972) utilizam o termo vaqueiro, generalizando o ofício dos peões e boiadeiros, tal como Nogueira (2002, p. 38).

O autêntico vaqueiro dos pantanais seja paraguaio ou seu descendente; seja mestiço, índio, poconeano; analfabeto ou semi-alfabetizado, é competente na sua profissão; hábil Condutor de boiadas; apto a desenvolver as atividades de rodeio, de doma, de carneada, de apartação; ágil no laço; valente na

\footnotetext{
${ }^{60} \mathrm{Na}$ terceira Comitiva acompanhada,em Julho de 2007, havia um boiadeiro/meeiro de Goiânia. Ele já executava este ofício na região, e ainda em outros estados como, por exemplo, no Pará. Ao que tudo indica, devido a problemas pessoais, precisou migrar para o Pantanal.

${ }^{61}$ Algumas das regras de convívio percebidas estão descritas neste Capítulo, no item 2.2, p. 93.
} 
bagualeação e, sobretudo, caprichoso artesão, quando prepara o couro $e$ fabrica suas traias de arreio. (...). Além das viagens, que têm de enfrentar, conduzindo boiadas de um local para o outro.

De acordo com fontes orais locais, o vaqueiro é um termo mais utilizado quando um peão exerce seu ofício com excelência: "O vaqueiro na nossa língua é quando é um peão muito bom, né, aí fala assim, aquele fulano ali é um peão vaqueiro, é um peão compreto" (BIGUÁ, 2009), mas muitos preferem ser chamados vaqueiros a campeiros, pois como dizem de forma bem-humorada: “campeiro é veado branco, melhor é vaqueiro ou peão" (JUAREZ, 2009).

No geral, o campeiro é aquele que mora na fazenda, sua lida é com o gado que está sendo criado, já o boiadeiro é aquele que viaja à pé 62 conduzindo o gado. Este último, quando executa apenas este tipo de trabalho, costuma possuir residência fixa na cidade onde mora sua família, mas de qualquer forma, termina-se uma viagem, em poucos dias parte-se para outra.

Há muitas similaridades e sobreposições entre as tarefas executadas pelos peões de campo ou campeiros e pelos peões-boiadeiros, peões de comitiva ou peões de estradão. Muitas vezes, o peão de campo pode estar trabalhando em uma fazenda e ser solicitado pelo gerente ou capataz para viajar com o gado. Outras vezes, o peão pode trabalhar durante certo período em uma fazenda e depois mudar de emprego, passando a prestar serviço em Comitivas. Assim é relatado em um documentário sobre o peão pantaneiro, produzido por Bigatão (2006):

Nós não somos boiadeiros efetivos, nós somos trocador de fazenda, vem de lá, vai para outra fazenda. (...). Hoje nós mexe com uma comitiva, amanhã ta trabalhando no campo, tira uma boiada aqui, tira uma vaquejada daqui pra lá, então o patrão fala - esse aqui é um bom peão! (Depoimento de José Anastácio de Arruda, 2006).

Neste mesmo sentido, foi o relato de Juarez durante a entrevista para essa pesquisa:

E o cara que viaja no estradão direto, tem tipo 3 dia, 4 dia, 5 dia de folga só. Ele chega, aí, conforme tá bom de viagem, ele chega hoje, descansa hoje e amanhã, noutro dia tem que sair de novo com outra Comitiva, porque ele não pode ficar parado, porque se ele perdê aquela viagem que vai sair,

\footnotetext{
${ }^{62}$ Esse termo é utilizado, pois apesar dos boiadeiros viajarem montados em burros ou mulas, significa uma referência ao gado, que vai andando, "à pé".
} 
depois de dois dias que ele chega, aí pode demorar 20 dias pra ele sair. Se ele tem família, ele passa necessidade, então ele tem que sair. Então talvez dentro de um ano, tem veiz dentro de um ano, ocê fica 20 dia, 15 dias na casa só, o resto tem que sair. (JUAREZ, 2007).

Em uma definição sucinta e clara, de acordo com o Cozinheiro da terceira Comitiva ${ }^{63}$, boiadeiro é aquele que vive boiadeando, ou seja, viajando com o gado e o peão é aquele que pára na fazenda, quer dizer, que mora na fazenda. Este sentido de estar e viver em movimento, viajando, puxando, conduzindo boiadas, traz a compreensão de que os boiadeiros “são nômades pela própria natureza do ofício, sobretudo” (NOGUEIRA, 2002, p. 38).

Conforme fontes orais, a experiência de trabalho costuma iniciar-se nas diversas regiões do Pantanal, mas ocorre principalmente, nas fazendas de gado. Assim afirma Barriga (2009) "é, aqui memo no pantanal, a partir de onze ano. Aí eu fui aprendendo assim, trabaiando com o pessoal no campo, ai eu fui aprendendo”. E também Juarez (2007):

Eu comecei a viajar no estradão, você fala viajá no estradão, né. (...). Eu comecei numa média de 18 pra 19 anos, só que eu nasci e criei em fazenda. Então, eu já tinha trabalhado muito em fazenda, dentro da fazenda, no campo, mas dentro da fazenda, né. Experiência de viajá pra fora, assim, eu não tinha, e eu era muito miúdo, não sabia.

O Cozinheiro da terceira comitiva acompanhada relatou ter aprendido o ofício acompanhando seu tio e começado a trabalhar como boiadeiro aos 16 anos. Sua primeira viagem ocorreu em 1986 e perdurou por 90 dias: "Poeirão vermelho no lombo. Saímo debaixo da chuva e cheguemo na seca". (informação oral).

Fontes locais relataram que, muitas vezes, o interesse por este ofício surge devido à imagem que os boiadeiros podem transparecer como pessoas alegres, festeiras e que possuem bastante dinheiro.

Quando eu via meus companheiro que chegavam, o que me mais me chamou foi no sentido de trabalho, porque quando eles chegavam, eles faziam uma viagem de uns 70 dias, eles chegavam, chegavam tudo bonado (...) com dinheiro, né, eles faziam aquela farra de cervejada e (...), aquela coisa... Eu falava, esse negócio deve ser muito bom, né? Essa turma chega com bastante dinheiro, chega tudo animado, mas pelo contrário viu? Muito cansativo, é, muito custoso pra pessoa que não tá acostumada. (JUAREZ, 2007).

\footnotetext{
${ }^{63}$ Terceira Comitiva significa o número da ordem de participação presencial da pesquisadora. (Tabela 1, p. 65).
} 
Para Biguá (2009) esta imagem ocorre porque o boiadeiro, dependendo do combinado com o chefe da Comitiva, costuma receber o pagamento no final de uma viagem e assim, chega às cidades com um montante significativo de dinheiro.

A iniciação dos boiadeiros no trabalho pode ocorrer por diversos meios. Na primeira Comitiva, como em outras ocasiões, foi observado o ensinamento tradicional de pai para filho ${ }^{64}$, assim como por meio de pessoas estranhas.

Eu aprendi com os outro. Assim, você saiu, foi trabalhar por conta já da pessoa, por conta minha. Aí fui aprendendo. Ocê trabaia com muita família, você não aprende nada, viu? Porque a familia qué briga cocê. E os outro, $q$ num é parente seu, ensina melhor q é parente, mais ou menos, o serviço (BARRIGA, 2009).

Apesar do entrevistado dizer que aprendeu a trabalhar "com os outro", também afirmou que a primeira vez que saiu em Comitiva foi na companhia de seu cunhado:

(...) eu peguei ela [Comitiva] na fazenda que eu tabalhava, ai eu fui na Comitiva. É eu, passando meu cunhado e eu queria ir embora da fazenda, aí ele falou então vamo embora, e aí eu fui! É aí eu fui na Comitiva, mas só que eu era novo, não sabia quase nada ainda de Comitiva, então eu ia no meio do pessoal, assim, só pra ir ajudando, aí eu fui tranquilo. (...) meu cunhado, que é casado cum uma irmã minha. E aí... foi...

Somando-se a estes relatos foi observado que o conhecimento do ofício do boiadeiro é transmitido oralmente ao iniciado e na maioria das vezes, se dá por elos familiares. Neste sentido, Banducci Junior (1995) aponta que há uma rede social de trabalho baseada em um sistema solidário de emprego entre os peões, pautada na comunicação entre eles. Isto deve incluir os boiadeiros.

Na década de 70, Rondon definiu que o boiadeiro "é o comprador de gado para revender, um comerciante de gado, o intermediário entre os fazendeiros criadores e os invernistas ou açougueiros." Eles apareciam mesmo sem dinheiro e efetuavam compras, conduziam o gado que vendiam aos açougueiros ou charqueadores, calculavam abate e

${ }^{64}$ O Sr Alfredo Miranda (falecido em 2006), na época, com 78 anos, ainda realizava Comitivas, tendo ensinado seu filho, Ramon Miranda, 42 anos, desde pequeno. Tal como o pai, atualmente, Ramon é condutor de Comitiva. 
condução, e depois voltavam ao fazendeiro que os recomendava a outros amigos. Eram pobres, mal conseguiam ganhar o necessário para sustentar a família e para pagar os cavalos que compravam fiado. Os invernistas de São Paulo, vendo vazias as invernadas de pastagem artificial e por lá não mais encontrando bois, entraram no sul de MT e, a seguir, no Pantanal, interessados por bois magros, para o que até então não havia procura, a partir do que começou a haver dois tipos de boiadeiros - o "boiadeiro de boi magro" e "boiadeiro de boi gordo". (RONDON, 1972, p. 98).

O comprador de gado ainda hoje é denominado de boiadeiro, talvez pelo costume no passado, mas este não é o mesmo que viaja em Comitiva. Há o boiadeiro comprador-vendedor de gado, que costuma ser o proprietário ou o gerente da fazenda e o peão-boiadeiro, que viaja nas Comitivas. "O boiadero que nóis fala é o dono do gado, sabe. E boiadero também, é porque nóis toca a boiada, né, a gente leva ela, né”. (BIGUÁ, 2009). O entrevistado ainda explica que:

Já tinha boiadeiro que já descia com o touro. Antigamente nessas fazenda aqui do Pantanal quando descia com uma tourada para vender e eles trocava a troco de gado, as vacas véias, boiada, e tal. Trocava os touro, por exemplo, eles desciam com 200 touros e aí ocê subia com quase uma boiada né. Trocava daqui pra cá quando tinha, pegava uma torada nelore, era novidade para os fazendeiro, que era só boizinho crioulo deles, mesmo, né, então, o povo que vinha de Minas, vinha de São Paulo, trazia muita boiada, muito bom, aí os fazendeiro trocavam, né. E aí eles vortavam, vortava com muita boiada, né. Então tinha boiadeiro que trocava touro a troco de vaca. Aí eles falava toureiro né, toureiro, descia os toreiro, aí eles trocava, marretava vaca véia a troco de touro, toruno véio.

A não ser o Condutor da Comitiva65, que costuma ter alguma posse, tal como a tropa de burros das viagens e os utensílios da cozinha da Comitiva, o peão-boiadeiro em raros casos possui algum bem material de valor econômico e recebe o suficiente para se manter, ou manter sua família, até a próxima viagem. Percebe-se, então, que há um contraste econômico e social, pois enquanto transportam boiadas que valem milhões, recebem cerca de um salário mínimo por mês e estão freqüentemente endividados.

\footnotetext{
${ }^{65}$ O Condutor é o chefe da Comitiva. Para mais detalhes, ver ítem 2.3, p. 101.
} 
$\mathrm{Na}$ entrevista com Juarez (2007) ficou evidente que, apesar da primeira impressão que tinha sobre a vida "bonada" dos boiadeiros, com a experiência adquirida posteriormente, ele concluiu que o dinheiro recebido é pouco, principalmente devido aos gastos com a própria viagem, como se pode verificar no trecho a seguir:

Que nem eu te falei cedo, eu não tenho, eu não tenho nenhuma vontade de, vontade de voltá, eu não tenho, porque, você ganha dinheiro, reunido, só que se você fazer as contas, é tudo retorno com você mesmo que você usa, traia sua acaba muito, e roupa. Roupa que você põe no estradão, você numa viagem de 40 dias aí, num presta mais, só pra aquilo, ai, você chega, e você quer comprar roupa boa, você tem que. Você compra uma calça boa pra uma viagem, você põe, só serve só pra viagem, porque já mancha, fica encardida, então ela só serve só pra viagem. Sempre que ocê chega, ocê tem que comprar um baixeiro, tem que comprar um pelego, aí você tem que fazer isso tem que fazer aquilo, então é uma coisa muito cansativo.

Segundo relatos, muitos boiadeiros gastam boa parte de seu dinheiro com bebidas e prostituição. O entrevistado Biguá (2009) aponta que muitos peões preferem o trabalho em Comitiva, uma vez que o Condutor, conhecendo o boiadeiro, pode adiantar o dinheiro da viagem antes mesmo de seu início. Ele diz ainda que: "tem muito companheiro que o que ganha na estrada já fica na estrada memo (risos), esperando a gente, né (...) bebe, passa em bera de corrutela [bordel] por aí e toma memo".

Outra coisa que aconteceu comigo, ocê xinga, ocê esbraveja, ocê fica pra morrê! Então nessas Comitivas sempre tem uns burros safados, uns burros que senta com buçal e acaba arrebentando teu cabo, sai correndo com tua traia, sabe, aí sua traia cai até a barriga dele, e acaba com ela e péin! Rebenta tudo, cai no chão, aí ocê tem aquele trabalho de tá, correndo atrás, pegando, arrumando tua traia, ocê chega assim, sua traia tá tudo arrebentado, rasga seu baixeiro, aí cê já fala, puta merda, essa viajem é só pra mim pagar a minha traia, que eu vou fazer, entendeu? Você fica p. da vida, você num qué nem, tá cum raiva do caramba. Só que vai acontecê alguma coisa boa lá na frente, você esquece tudo, aí ocê começa, quando ocê vai indo, ai ocê chega num lugar, ocê consegue arrumar uma pinguinha, entendeu. A pinga é, tipo, uma injeção de ânimo nos, no peão do estradão, você vai indo, 10, 15, 20 dias e nada, você num tem uma sobremesa, num tem uma salada, ocê num tem nada disso, é o arroz, a comida, é o arroz, feijão com macarrão, essa é o básico de todo dia a dia, e o café cedo. Aí chega num lugar, tem um barzinho, ocê passa muita necessidade também, sabe, (...), esses negócio, você ta na cidade, o cara vai lá, compra no bar um baixeiro que você quer comprar, pra usar na estrada, aí você acha, compra uma pinguinha, você fica nossa senhora, (...) fica faceiro, parece uma criança ganhando doce. (JUAREZ, 2007). 
Para o entrevistado Barriga (2009), são comumente os boiadeiros solteiros que apresentam tal comportamento:

\begin{abstract}
Ah, isso é normal, o pessoal toma pinga aí, num tem ôtra coisa pra ele tomá, se toma, a primeira coisa que chega num, num buteco assim, num bolicho [armazém, bar], é tomá pinga, cerveja, farreá, num tem nada. Já pega o dinhero pra gastá, já, né. Ah, gasta tudo, chega na cidade, a primeira coisa que vai, é estourá dinheiro numa bebida, num liga pra nada, quem tem família não, quem tem família é normal, vai embora pra casa, dá o dinheiro pra muié, que ta precisando lá, mai o sorteiro... Se chega ta passando numa corrutelinha assim, tivé a muierada vai indo, vão lá bagunçá lá, tomá cerveja e fazê uma bagunça memo, durante à noite, né? Isso é, eles gosta de fazê isso.
\end{abstract}

Um dos grandes problemas deste ofício é sua informalidade. Como costumam prestar serviços sem contrato ou registro de trabalho, não há levantamento de dados estatísticos sobre as Comitivas ou sobre os boiadeiros. Quando registrados por algumas fazendas, enquadram-se dentro da categoria de trabalhadores rurais, pois nestes casos, trabalham principalmente como peões de campo. Assim, este tipo de mão de obra não se distingue dentro das complexidades ocupacionais existentes na estrutura de trabalho deste sistema produtivo e percebe-se que não tem sido feito o registro da presença ou da diminuição das Comitivas de boiadeiros.

É interessante observar que apesar de estarem ligados ao mercado mundial, eles próprios vivenciam outro tipo de cotidiano que perpassa por áreas remotas e está marcado

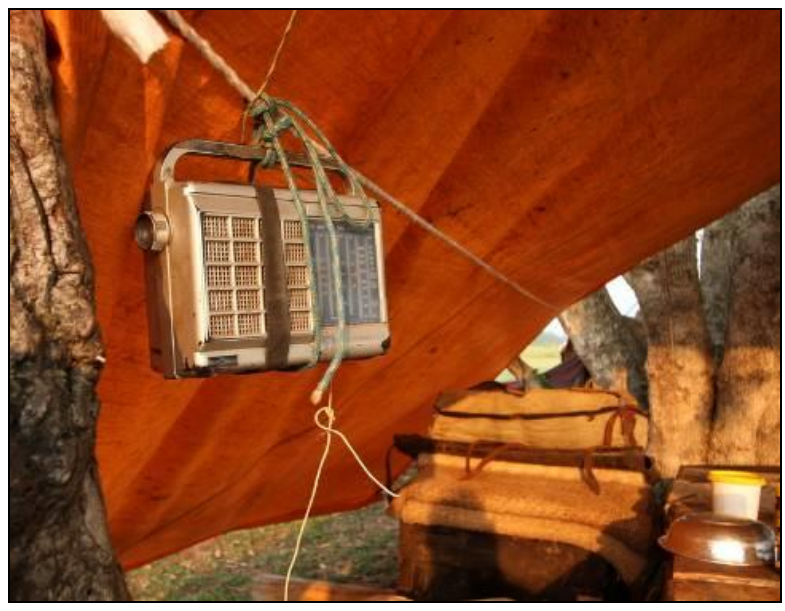

Fig. 22 - Rádio em ponto de parada, na Comitiva da Fazenda Redenção. pela invisibilidade deste serviço. Tal fenômeno não significa, porém, que os boiadeiros são alienados aos acontecimentos do mundo. Durante as paradas de almoço ou pouso e entre uma viagem e outra se comunicam com moradores das fazendas e dos municípios, recebendo e repassando 
informações. Além disto, costumam levar rádio de pilha (Fig. 22) nas viagens para escutar notícias, e principalmente músicas. Há uma estação chamada "Alô Pantanal” ${ }^{66}$, que é relevante para os boiadeiros, pois presta serviço de informações sobre os moradores das fazendas, envia recados e avisa também sobre datas das viagens das Comitivas.

Atualmente, os boiadeiros também utilizam celulares. Isto foi observado na terceira Comitiva, em um dos pontos de parada, no Retiro Santo Onofre (Fazenda Santa Filomena). O Cozinheiro subiu o mais alto possível sobre um carro de boi abandonado e conseguiu sinal para falar com sua esposa, recebendo notícias e informando-a sobre a data provável do término de sua viagem.

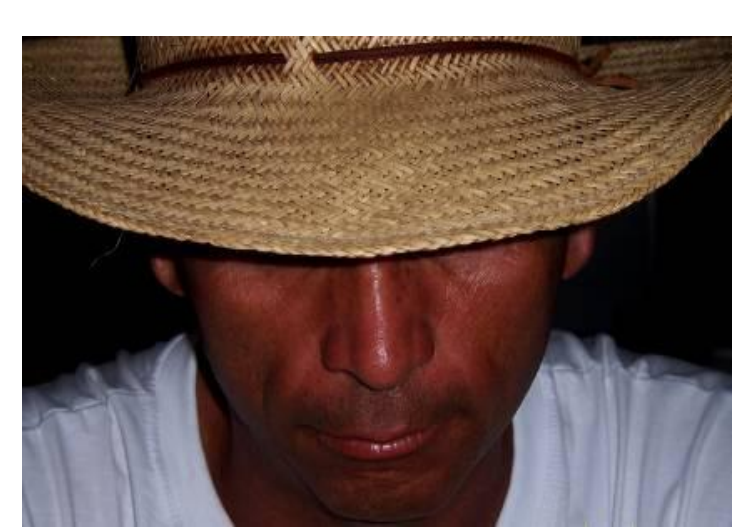

Fig. 23 - Juarez. Fonte: Mari Baldissera.

"Aquele tempo o pantaneiro era mais bobo (...) que hoje em dia tudo é sabido, desde criança já vê televisão, já sabe o que tá acontecendo no país estrangeiro". (Depoimento Sr. Alonso, BIGATÃO, 2006

No que foi possível observar, os boiadeiros são muito respeitosos. Aqueles com quem se teve contato somente na Comitiva, durante conversas com a pesquisadora,costumavam permanecer com a cabeça baixa e chapéu na frente dos olhos. Já aqueles que hoje possuem) outra profissão, como os entrevistados Juarez e Barriga, e que hoje trabalham como guias de ecoturismo, o trato é um pouco diferente, mais parecido com "pessoas da cidade".

\footnotetext{
${ }^{66}$ Cf. BIGATÃO (2006; 2009).
} 


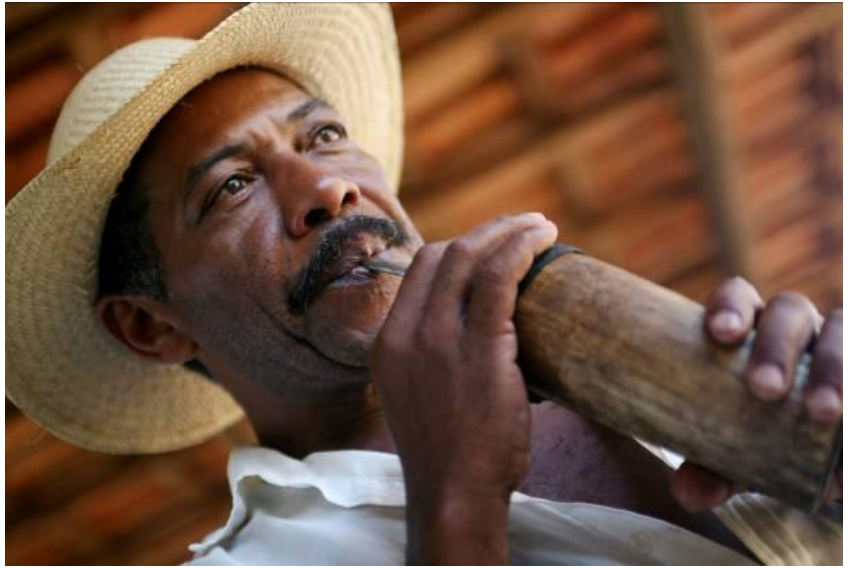

Fig. 24 - Seu Zé Preto tomando tereré. Fonte: Pousada Xaraés.

Todavia, em poucos dias de convivência, eles já lhe arranjam um apelido, como é de costume apelidar ${ }^{67}$ pessoas, assim como os animais. E é enquanto tomam o mate, durante $\mathrm{o}$ amanhecer, em volta do fogo, ou o tereré (Fig. 24) durante a marcha da boiada, que costumam contar um causo ou alguma anedota e então, vão se soltando. Quando estão reunidos brincam muito uns com os outros, emprestando termos de seu cotidiano de trabalho.

O mate para os pantaneiros é a bebida preparada com erva mate e água quente, já o tereré é feito com a mesma erva e tomado com água fresca ou quando possível, com água bem gelada. Este último é apreciado por grande parte dos moradores dos

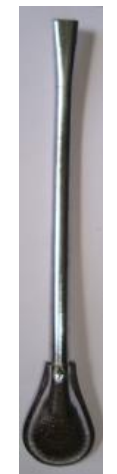

Fig. 25Bomba Estados de Mato Grosso e Mato Grosso do Sul.

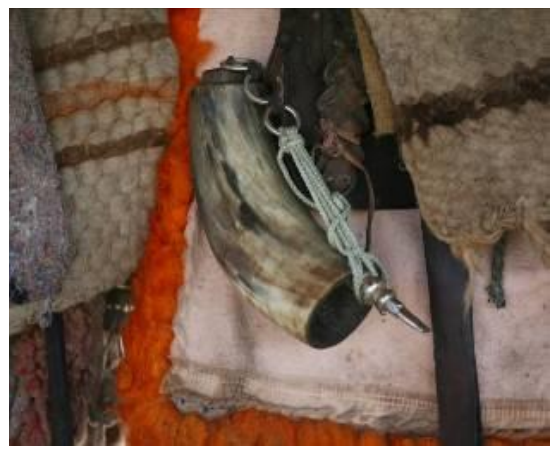

Fig. 26 - Guampa e bomba amarradas a traia.

Ambas as bebidas são preparadas dentro de uma guampa, que é um chifre de boi fechado do lado mais estreito com um pedaço de madeira, chamado de tufo. Dentro da guampa coloca-se uma pipeta de metal, chamada de bomba (que possui tipo de filtro/peneira na extremidade Fig. 25), um punhado de erva e o restante da água e bebe-se através desta bomba. Estes objetos são pessoais e ficam amarrados na lateral da cabeça do arreio de suas montarias (Fig. 26). A guampa, amarrada por um barbante, permite que durante a viagem não precisem apear para pegar a água, quando a retiram de

\footnotetext{
${ }^{67}$ Na primeira Comitiva os boiadeiros apelidaram a pesquisadora de Paulistinha e na segunda Comitiva era chamada pelo primeiro nome, Maria.
} 
uma baía, corixo ${ }^{68}$ ou de um rio. Durante os períodos de estiagem precisam carregar um cantil. Biguá (2009) coloca que “se o peão não tiver um cantil, também, ele tá enrolado”.

Um dos boiadeiros deve ser o cevador, que normalmente, oferece o tereré ou o mate ao indivíduo que estiver do seu lado direito. Por sua vez, este deve bebê-la e devolvê-la ao cevador. A bebida é passada de mão em mão, em forma de roda, ou sempre na mesma seqüência. Somente deve-se dizer obrigado quando não se quer mais a bebida. Durante a marcha, dificilmente é possível beber o tereré em roda, entretanto podem juntar-se dois ou três boiadeiros (Fig. 27).

São várias as conversas e brincadeiras quando se está tomando esta bebida, mas o que parece ser a maior diversão do boiadeiro é cartiá com o outro, que quer dizer "contá vantagem, coisa duvidosa" (JUAREZ, 2009), ou seja, brincar, tirar sarro, desafiar, sempre de forma muito maliciosa e inteligente. Nogueira (1990) também ressalta o bom humor, imaginação fértil, dos pantaneiros, sobretudo para inventar mentiras fantásticas.

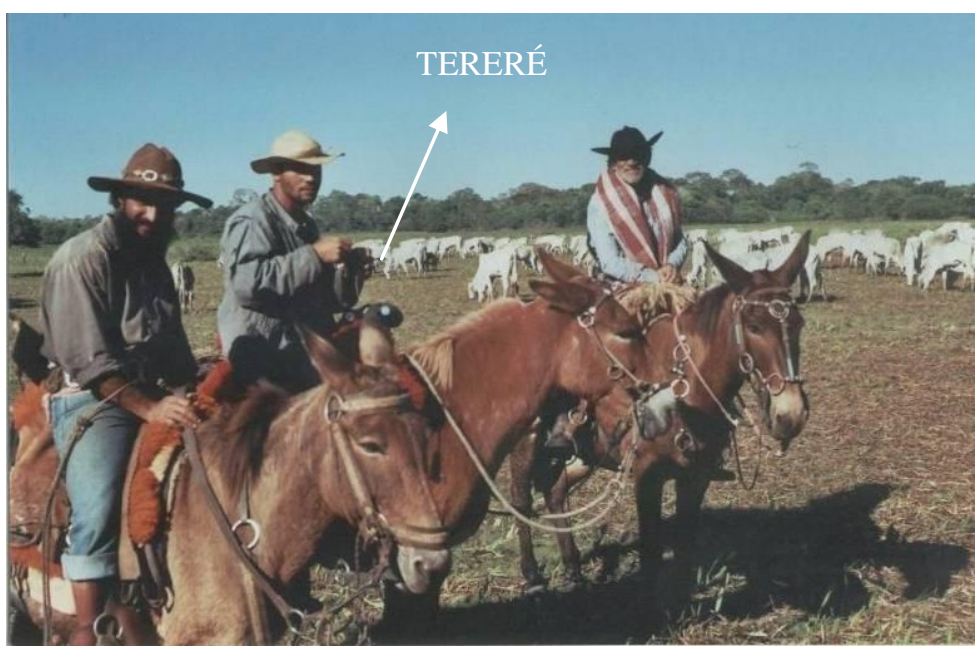

Fig. 27 - Sr. Jair (Beto Carreiro), Wilson e Barba tomando tereré durante a marcha.
Uma brincadeira que eles fazem com freqüência é falar de uma pessoa que está na roda, mas não usar diretamente o nome dela, direciona-se a fala para alguém da roda, usando o nome de algum parente, como cunhado, irmão desse alguém,

mas na verdade estão falando da pessoa presente.

\footnotetext{
${ }^{68}$ Ver definição de corixo na p. 146.
} 
Os boiadeiros podem ser tímidos em um primeiro momento, mas esta não é uma característica marcante e sim a de serem brincalhões. Já quando estão falando algum assunto mais sério, são de poucas palavras.

O modo de se vestirem é voltado à lida do trabalho. Usualmente vestem calça jeans; guarda (calça de couro); cinto e botas de couro (estas últimas são usadas, normalmente, com esporas); guaica (onde guardam arma de fogo e balas); faixa paraguaia69 (feita de tear); camisa; chapéu de carandá (Fig. 31) ou de feltro (Fig. 30). Entre seu corpo e a faixa paraguaia costumam carregar o e o machete composto pela faca e chaira para amolar, guardadas em uma bainha de couro (Fig. 32). Por vezes, podem vestir também bermuda, é o que coloca Juarez (2007):

Normalmente ele usa bermuda, calça de couro então, toma muito pouco espaço no dobro, porque ele só usa, ele leva 4 bermuda, ele faz uma viagem 40 dias com 4 bermuda. Também quando chega, normalmente não presta mais. Então ocê pega bermu..., essas calça velha, corta, faz bermuda e leva. Aí você usa uma semana, quando daí um pouco pra ocê passá uma semana pra ocê passá. Quando não dá, quando ocê chega, ocê já, já chega fora, assim é que é. Mas é cansativo.

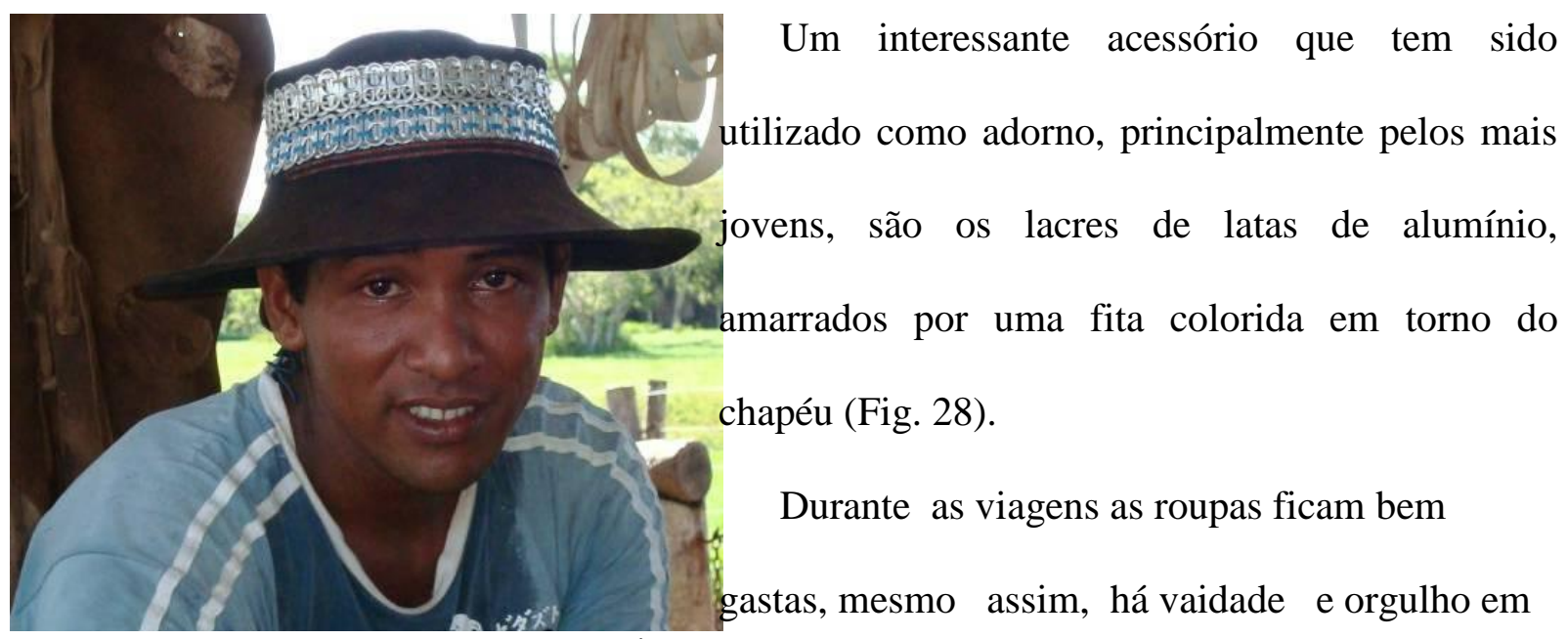

Fig. 28 - Isopor (apelido). Detalhe do chapéu enfeitado com lacres de latas de alumínio. vestirem-se.

\footnotetext{
${ }^{69}$ Segundo fontes locais, a faixa paraguaia (fig. 31) também ajuda a proteger a coluna, mantendo-a mais ereta, estável. A pesquisadora, durante as Comitivas, experimentou usá-las, sentindo o mesmo efeito.
} 


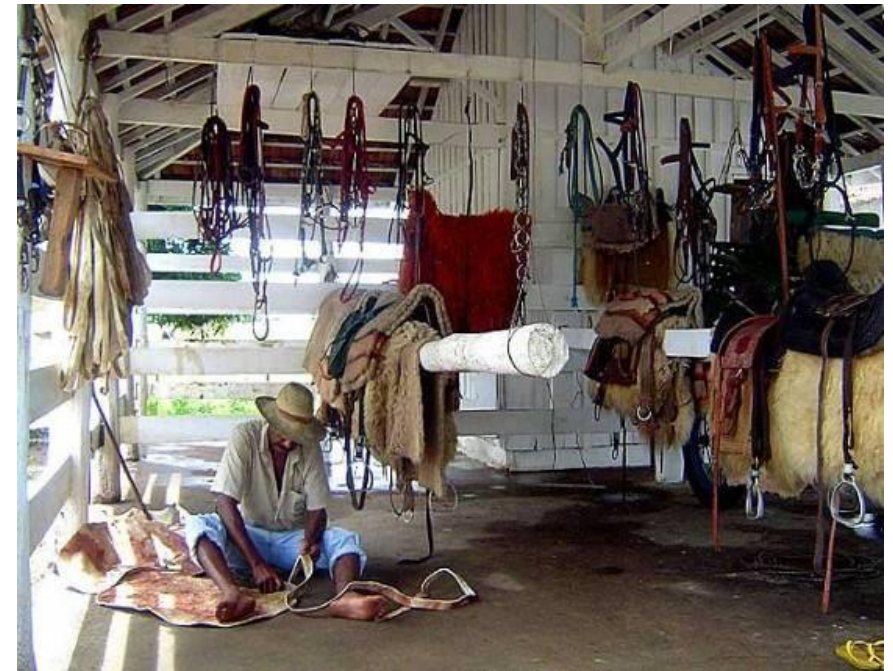

Fig. 29 - Sr. Zé Preto trabalhando com o couro de vaca para uso na própria tralha. Fonte: Pousada Xaraés.

diversos objetos, pricipalmente para utilização em seu trabalho, tais como, rédeas, laços, arreio (tipo de cela) e bruaca $^{70}$. Com lã de carneiro fazem o pelego (manta de lã usada sobre o lombo do cavalo para montaria) e o conchonilho (reaproveitamento do pelego gasto).

O conjunto de materiais para montaria é chamado de traia ou tralha ${ }^{71}$ e pode também referir-se aos objetos pessoais do peão de comitiva, o que inclui o dobro (mala).
Além disso, foi observado que os boiadeiros costumam ter uma postura corporal altiva, tanto apeado quanto sobre sua montaria. Alguns dos boiadeiros possuem habilidades exemplares como artesãos (Fig. 29). A partir do couro de vaca são confeccionados

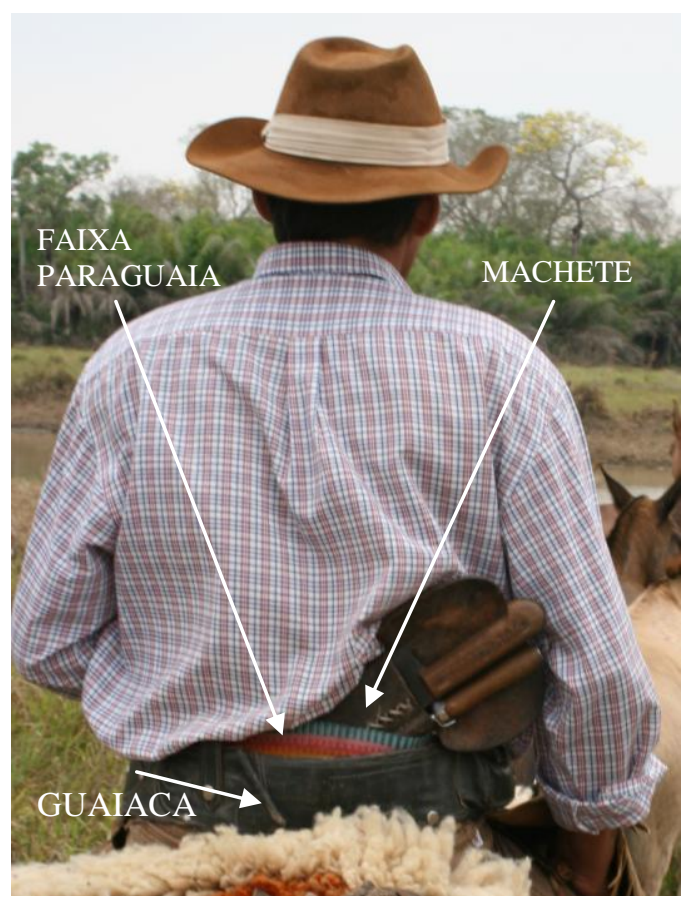

Fig. 30 - Ramon. Detalhe para acessórios. Fonte: Thiago Rocha.

A traia para encilhar o cavalo ou burro é constituída por buçal (cabresto) e cabeçada (freio e rédeas), que são colocados nesta ordem na cabeça do animal. Em seguida, colocam-se sobre seu lombo os baixeiros (duas mantas de lã), carona (proteção de couro), arreio, travessão (tira de couro que se amarra ao arreio e à barriga do cavalo), pelego, baldrana

\footnotetext{
${ }^{70}$ Caixa de couro, com estrututra de madeira, usada nas viagens de Comitivas para guardar mantimentos e utensílios da cozinha. Ver fig. 45; 46.

${ }^{71}$ Nogueira (2002) Descreve e ilustra cada etapa para se encilhar o cavalo.
} 


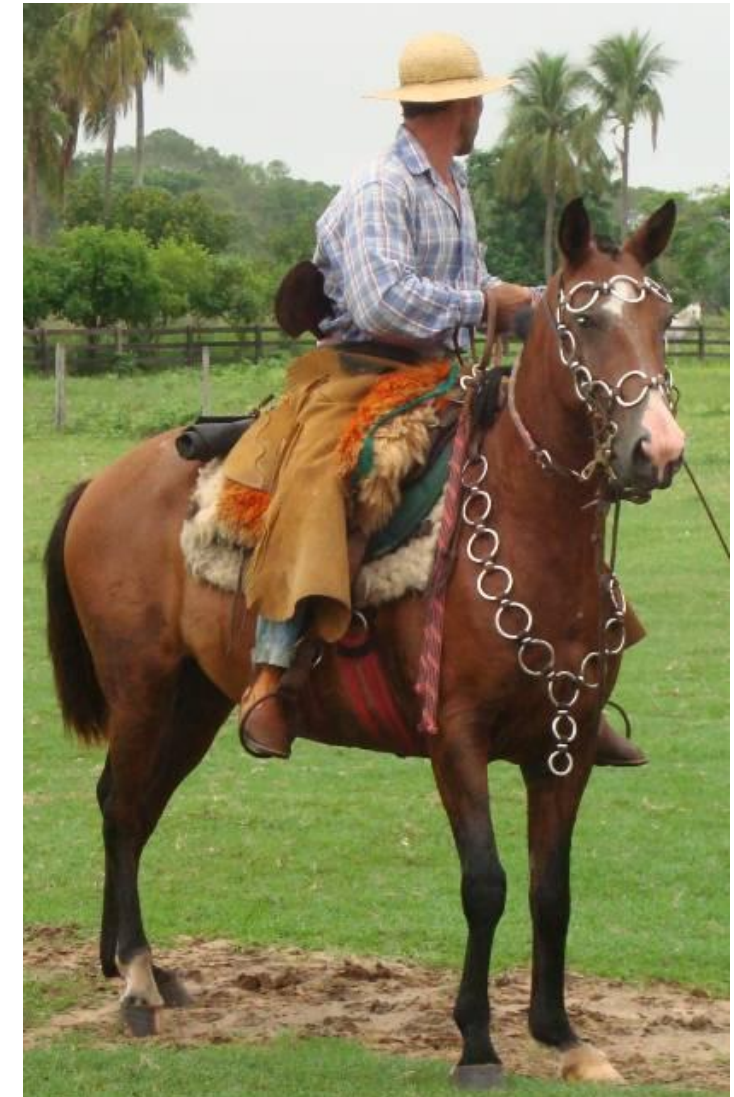

Fig. 31 - Boiadeiro anônimo. Ponto de pouso, fazenda Nossa Senhora do Carmo. (proteção de couro), chincha (tira de couro para amarrar a baldrana) e, nesta última, amarra-se o laço. Podem ser colocadas peiteiras, que ajudam a firmar a tralha e adornam o animal com várias argolas de metal. Por último amarrada na parte de trás do arreio é colocada a capa de chuva do boiadeiro (Fig.31- capa preta dobrada).

Uma importante ferramenta de trabalho para os boiadeiros é o arreiador ou arreadô (Fig. 32), que serve para doma da boiada, para “espancá o bovino”. É feito com cerca de dois metros de corrente, dois metros de couro, um cabo de madeira ou de osso e uma "ponteira" (material de saco de batata ou de laranja). Há uma técnica para ser lançado em direção a cabeça do boi, fazendo um barulho forte, como um estalo. Para doma do burro também é utilizado uma ferramenta chamada reio, que é um pequeno chicote de couro com cerca de $40 \mathrm{~cm}$ (Fig. 33).

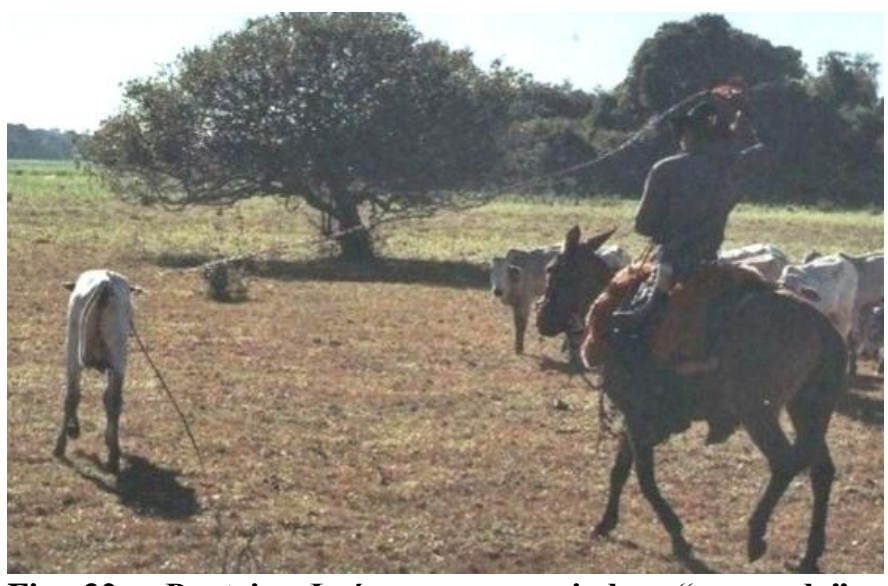

Fig. 32 - Ponteiro Luís com o arreiador, "surrando" o animal. (terceira Comitiva).
"Ah, o arreadô é o necessário, né. O laço também, talvez corre, uma rêis, assim, uma vaca, ocê tem que laçá ele pra podê vorta, né. E o arreadô é o mais importante memo, pra surrá o gado, o gado arrespeita muito, estalô aqui, eles já sabe que é pra para já." (BIGUÁ, 2009).

$$
\text { A tralha do boiadeiro é, }
$$
geralmente, um bem de uso pessoal e 
percebe-se que uma relação afetiva, de orgulho por estes objetos, havendo certo significado de status. São utilizados pelegos em forte tom avermelhado, adornos com argolas, que dão beleza à tralha e assim, também ao boiadeiro.

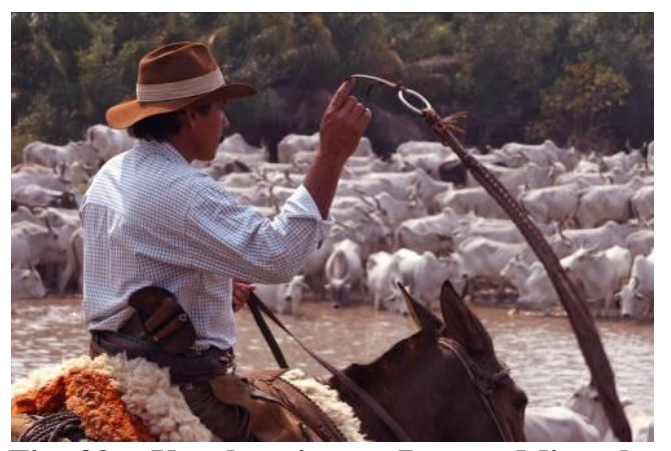

Fig. 33 - Uso do reio por Ramon Miranda. Fonte: Thiago Rocha
Tem peão que não tem nada na traia, aí cê olha assim, é aquele peão sem graça, parece que não tem nada, aí $c \hat{e}$ vê um peão com uma traia bem bonita, bem argolada, uma calça de couro cheia de margarida, né, a guaiaca cheia de fivela, aquilo tudo já levanta aquele peão. Às vezes a pessoa fala assim - sou peão - porque vestiu uma calça de couro e um chapéu na cabeça e fala que é um peão! (Faz gesto de negação com a cabeça) Eu tenho orgulho de ser mulher do peão Jonas, porque ele é um peão exemplar". (Claudete em BIGATÃO, 2006). ${ }^{72}$

Durante a participação nas Comitivas foi observado que a relação entre o boiadeiro e sua montaria é, no geral, uma relação de amizade e apesar das fazendas na região ainda utilizarem a doma tradicional ${ }^{73}$, se nota muito cuidado para que esta permaneça saudável. Em algumas ocasiões, durante o acompanhamento presencial das Comitivas, os boiadeiros desentenderamse com seus burros, nestes casos, costumam ralhá com eles, brigar, dizendo palavras como: sua mula véia nojenta; burro desgraçado, fididu; troço assombradu!

Na terceira Comitiva, uma das mulas da tropa cargueira não estava aceitando ser encilhada, pelo Cozinheiro e quando o procedimento foi finalizado, disse-lhe algo como: Agora cê vai ficá com traia o dia todo, só pra largá de sê teimosa! E então, ao invés de se fazer o revezamento no período da tarde com outro animal, a mula foi obrigada a trabalhar todo o dia.

\footnotetext{
${ }^{72}$ Bigatão apresenta em seu trabalho, uma contextualização sobre as origens da formação cultural do pantaneiro (em fase de elaboração). BIGATÃO, R. I. A construção da imagem do peão pantaneiro: a inscrição das mídias tv e rádio na cultura mestiça do pantanal de MS. 33f. Dissertação (Mestrado). Programa de Estudos PósGraduados Comunicação e Semiótica. A ser editadado pela Pontífica Universidade Católica de São Paulo. São Paulo, 2009.

${ }^{73}$ Neste tipo de doma, muitas vezes, pode-se machucar o animal ou este pode ser machucado pelo domador (peões).
} 
Segundo relatos dos boiadeiros não se pode deixar que o animal domine o homem, senão perde-se o respeito, podendo ser perigoso. Semelhante a esta forma de pensar e agir com a tropa, é a de lidar com o gado, durante as viagens.

Uma frase muito citada na região e também na literatura é a de que o boi cria o pantaneiro. (IBGE, 1975; BARROS, 1990). À primeira vista, pode parecer certa contradição com a afirmação no parágrafo acima, pois esta frase traz uma conotação passiva ao modo de ser do pantaneiro. Entretanto, ao mesmo tempo em que se procura dominar estes animais e se faz o manejo do gado, as fases de cria e recria são pacientemente aguardadas durante as diferentes estações das águas. Ou seja, o ambiente experienciado interage e integra-se com o ser criando relações que podem representar diversos sentidos e revelam sua complexidade.

Outro ponto observado nas Comitivas acompanhadas refere-se à amizade entre "os companheiro" de viagem. Há um sentido de cooperação e união entre os boiadeiros, percebido como uma necessidade nas longas viagens, e segundo fontes orais, também por permanecerem grande parte do tempo isolados do convívio social com a família. É o que se pode observar neste depoimento:

(...) tudo recompensa, nas veiz, na chegada, porque normalmente são tudo mundo, são reunido, né. Esses peão que a gente fala que viaja junto, é muito unido, né, chegam, normalmente eles arrumam um jeito de tomar uma cerveja junto ou comê uma carne junto, ocê entendeu. (JUAREZ, 2009).

Porém, às vezes ocorrem desavenças que podem resultar em mortes, sobretudo quando ingerem bebidas alcoólicas. Os locais onde ocorrem estes fatos, normalmente, tornam-se lugares assombrados, gerando histórias orais $^{74}$ que são transmitidas entre moradores e boiadeiros do Pantanal.

Lá perto da fazenda aonde eu fui criado, mataram um peão de boiadero, lá. Quem que achou o corpo dele lá foi o meu irmão, o Jair. Eu tinha 14 ano e o Jair tinha 13. Aí a gente tinha parado já de entregá leite, a gente tirava lá na fazenda e levava de bicicleta pra entregá lá na cidade, de madrugada, porque tinha que tirá o leite, por no garrafão e levá pra cidade e entregá

\footnotetext{
${ }^{74}$ Cf. BANDUCCI JUNIOR, 1995; FERNANDES, 2002; PIERETTI, 2007, para mais informações sobre histórias orais pantaneiras.
} 
pra í pra escola de manhã ainda, então tinha que ser madrugada. Aí meu irmão ia passando e sentiu um chero forte, chero de carniça, né, ele ficô curioso, (...) coragem, ele falô, ah, eu vô oiá o que que é, diz que parô a bicicleta, a bicicleta carguera, né, parô a bicicleta, puxô, parado ali, pegô a lanterninha dele e saiu em cima dum peão morto, tava podre já, tava de bota, chapéu, tudo. Um peão de boiadeiro, então ele conta a história desse cara lá que aparece. E eu conheci o cara. A turma conheciam ele. Tiveram arribando uns boi lá, uns quanto dia (...). Eles iam toma cachaça e voltá de novo, pra pastorejá. Toma uma pinga e vinha, voltaram, aconteceu uma briga na estrada, assim uns $3 \mathrm{~km}$ da fazenda, aí os companhero dele brigaram, depois pegaram o cara lá e matô ele, é, deu uma facada nele e matô, matô ele assim, ele caiu do cavalo, né, ele caiu do cavalo assim e ficô, tanto é que nóis foi mexê com ele, foi tirá da bota dele, a carça, o pé saiu tudinho, ficô só o osso, aí num tem como mexê com o corpo mais. (...). O cabelo tava tudo saindo, sabe, pegava assim, saia tudo.

E hoje tem história desse cara aí. Qué vê, faiz 30 anos, eu tinha 12, agora tô com 42. Faz 30 anos, história lá, quando passa sempre dô uma parada naquele pedaço assim (...). E bem em frente da onde ele morreu, da onde enterraram ele, tinha um pé de tamarindo. (...) encostado no pé de tamarindo. Ah, ele tava lá parado em frente do pé de tamarindo. Nóis num vimo ninguém não. As veis acontece isso. (JUAREZ, 2009).

O modo de ser do boiadeiro inclui suas relações com o mundo, suas crenças e práticas cotidianas. Nesta pesquisa considera-se que o boiadeiro é uma figura típica na região pantaneira. Conduzem grandes boiadas por centenas de quilômetros e viajam até meses, montados em burros e penetrando inúmeras paisagens, onde muitas vezes, não há outra opção de acesso. Estas boiadas pertencem a fazendeiros criadores e invernistas que necessitam transportá-las para fins comerciais, com objetivo de executar o manejo entre fazendas ${ }^{75}$ durante as fases de cria, recria ou engorda do gado, ou também por motivos de compra/venda entre fazendas ou frigoríficos.

Apesar de pesquisas contemporâneas não abordarem assiduamente os boiadeiros, autores mais antigos como Rondon (1972) e Corrêa Filho (1946) dedicaram algumas páginas ao tipo cultural dos boiadeiros e sua inserção nos espaços culturais, sociais e econômicos que ocupavam. Deste modo Rondon (op. cit.) os homenageia, discorrendo que foram heróis notáveis que marcaram a história e merecem uma estátua, por enfrentarem as dificuldades no trabalho durante as viagens pelos sertões.

\footnotetext{
${ }^{75}$ Sobre o manejo do gado nas fazendas pantaneiras, ver nota de rodapé 7, p. 28.
} 


\subsection{Na batida das Comitivas de boiadeiros}

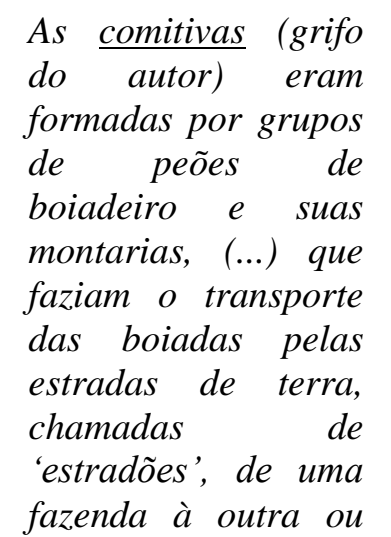

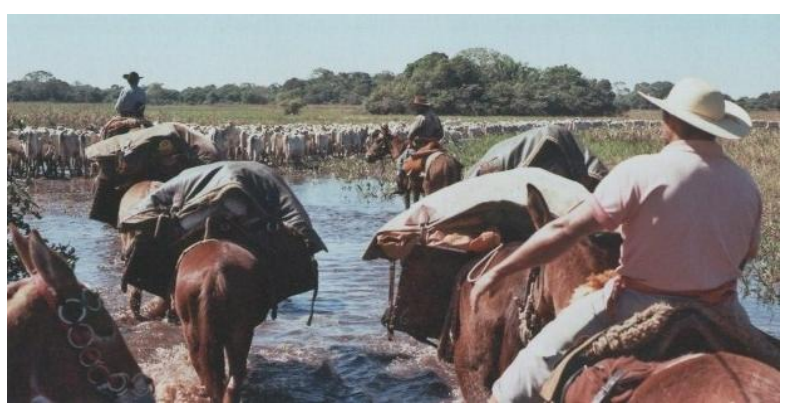

Fig. 34- Saída da terceira Comitiva. Cozinheiro e tropa cargueira passando à frente da boiada.

da invernada para o matadouro, percorrendo grandes distâncias, durante dias a fio, que eles chamavam de 'marchas', antes do advento dos caminhões-gaiola e das estradas pavimentadas. Esse fenômeno sócioeconômico e cultural ocorreu na região compreendida pelo norte do Paraná, São Paulo, Triângulo Mineiro, Mato Grosso e Goiás, praticamente extinguindo-se no Estado de São Paulo na década de setenta do século vinte. (GOÉS, 2005).

De acordo com Souza (1986), em setembro de 1737, abriu-se a via terrestre à Cuiabá através de Goiás, ficando franqueada a rota a São Paulo e Minas Gerais. Por este caminho, devem ter dado entrada inúmeros rebanhos, vindos a pé de outros pontos. Então, na região do Pantanal, podemos conjecturar que esta data significa o início das Comitivas de boiadeiros.

Diferentemente de outras regiões, o regime das águas do Pantanal e o seu isolamento têm sido fatores decisivos na criação do gado como atividade econômica viável e, conseqüentemente, na existência das Comitivas de boiadeiros. Estas são indissociáveis, sendo que as Comitivas costumam ocorrer antes da estação da cheia, pois há áreas alagáveis onde não é possível manter o gado, ainda que estejam adaptados ao regime das águas na região.

As Comitivas podem ser chamadas de duas maneiras ${ }^{76}$ : Comitiva de fazenda; em que os peões levam a matula, (almoço) ${ }^{77}$, retornando em poucos dias e a Comitiva de viagem; em

\footnotetext{
${ }^{76}$ Atualmente, com a crescente demanda do ecoturismo, há outra forma de realização da Comitiva, com intuito do acompanhamento de turistas, às vezes, sem haver a real necessidade de se transportar o gado. Apesar desta pesquisa não abordar este tipo de Comitiva, entende-se que isto pode significar um incentivo ao resgate das tradições locais.
} 
que sempre pernoitam com o gado e podem demorar alguns meses para retornar. Uma ressalva é que as pessoas que trabalham em uma fazenda e o proprietário desta costumam chamar "sua" Comitiva, como Comitiva de fazenda, podendo, neste caso, ocorrer uma viagem mais longa, na qual os funcionários da fazenda conduzem o gado e quando retornam voltam ao trabalho fixo na fazenda.

Juarez (2009) coloca ainda que quando uma viagem ocorre por um curto período de tempo, pode ser chamada de mala de garupa, "porque leva a mala dele na garupa, vai de mala de garupa, fazê uma pitoquinha, mala de garupa”.

Eu comecei a viajar no estradão, você fala viajá no estradão, né. Você fala: vou fazer uma viagem, ou uma perigosa, é tudo a mesma coisa (...). Uma perigosa é um tipo duma viagem também, né. É um palavreado do peão, né. $O$ cara fala, vamo faze uma pitoca: É uma viagem curta. Você fala, vamo fazê uma pitoca, é uma viagem de 20 dias, 15, de 10. Uma pitoca. Você fala, onde ocê vai? Vou fazer uma pitoquinha aí, então o peão já entende que é uma viagem curta (Ibid., 2007).

Além de confirmar as denominações acima, Biguá (2009) acrescenta que a viagem de curta duração também pode ser chamada de "suja baixero, porque conforme a situação que a gente tá, tem muitos companhero que nem... Você vai só sujá baxero, num dá nada”. Baixeiro é a manta de lã utilizada para encilhar o cavalo, isso quer dizer que só irão sujar suas mantas, não ganhando quase nada de dinheiro. Ele explica ainda que viagem perigosa é outro sinônimo desta, "é a mesma coisa, perigosa é uma viagem meio nojenta de fazê"”.

Fontes orais locais relataram que, antigamente, enquanto os boiadeiros conduziam o gado a pé, o Cozinheiro, às vezes, viajava em carro de bois, os quais usavam cangalhas atadas ao pescoço. Porém, observou-se não haver mais esse meio de transporte na região, em muitas fazendas vê-se apenas rodas e carros de bois abandonados ou como objetos de decoração.

\footnotetext{
${ }^{77}$ Normalmente, é preparada uma farofa de mandioca com carne seca ou frango, sendo carregada em um saco plástico grosso.
} 
Atualmente, o Cozinheiro costuma ir sobre montaria, levando os burros cargueiros, mas pode também utilizar um trator ou carro ${ }^{78}$. Durante a participação da segunda comitiva, ao invés do Cozinheiro ir sobre o lombo de uma mula e conduzir a tropa cargueira, o proprietário da fazenda solicitou para que fosse com sua caminhonete, isto foi justificado como uma alternativa para não desgastar animais da tropa e não maltratas as reses, pois iriam ter que marchar em estradas de asfalto e cascalho.

As razões para optarem por este tipo de transporte também pode estar relacionado à facilidade de acesso à estrada de asfalto ou cascalho e/ou por escassez de água nos campos para saciar a sede, como foi observado na época da entrevista com Biguá, que viajava conduzindo um trator.

Segundo relatos locais, as reses são criadas, geralmente, na região do Pantanal e quando estão com cerca de dois ou três anos são vendidas aos fazendeiros invernistas, que costumam possuir fazendas localizadas na serra, ou seja, na região da Serra da Bodoquena ou de Maracaju. As reses permanecem por volta de doze meses para manejo de engorda e então são revendidas aos matadores, frigoríficos e charqueadas. Por vezes, estas fazendas de engorda são dos mesmos proprietários das fazendas de cria.

O comércio do gado se intensifica no período entre a estação das águas, de abril a outubro, quando é possível movimentá-lo, o pasto está mais abundante, o gado mais gordo. A vacinação também deve ocorrer neste período, pois durante a cheia torna-se difícil manejá-lo.

Quando perguntado a alguns boiadeiros sobre o motivo da viagem da Comitiva é comum a resposta: "Tamo fugindo ou tamo correndo da água". Apesar de não haver dados numéricos, podemos ponderar que no Pantanal não somente estas viagens, mas todo o sistema de manejo do gado ocorre estreitamente de acordo com a estação climática.

\footnotetext{
${ }^{78}$ Este último veículo não é muito comum, mas costuma ser uma caminhonete do Condutor (o qual, nesse caso, pode cozinhar para os boiadeiros).
} 
Segundo pecuaristas, antes mesmo do gado ser comprado é analisada sua forma de transporte, que poderá ser embarcado, ou seja, contratam-se caminhões boiadeiros ${ }^{79}$ ou então o gado vai tocado, como costumam dizer quando optam pela Comitiva de boiadeiros.

Essa escolha dependerá de diversos fatores que podem ser muito variáveis, tais como distância, regime das águas, acesso, tipo de gado, etc. Entretanto, a Comitiva é necessariamente escolhida quando não houver acesso por caminhão, quer dizer quando não há estradas ou estas estão impossibilitadas de passagem, como ocorre durante a época das enchentes. No pico deste período, nem mesmo a pé pode ser bom viajar, a não ser que o gado seja adulto e esteja em bom estado de saúde.

Para optarem pelas Comitivas são necessárias condições adequadas para o pouso, (pernoite), o que inclui a autorização do proprietário ou gerente da fazenda onde irão pousar e local para encerrar o gado. É também desejável que o gado não esteja muito fraco, senão normalmente, será transportado por caminhão. Porém, segundo fontes orais, se for considerada a saúde do gado, desde que seja bem conduzido pela Comitiva, o rebanho não sofrerá, pois vai pastorejando, durante a viagem.

Pastorejá significa só solta do mangueiro, aí o fazendeiro te dá uma invernada pra você dá pasto pro gado, que já tá muito fraco, num tá conseguindo viajá. Aí ocê fala vô pastorejá, daí o cara acerta lá com o cara lá, o fazendeiro o preço que ele vai cobrar e ocê solta o gado naquela invernada e cuida ele, igual cê ta viajando no estradão, né, vai acompanhando ele, cuidando, vira pra lá, vira pra cá, aí quando ta chegando na hora de encerrá, ocê sai de vorta pra encerrá, aí no outro dia, você vai (...), solta pra pastorejá de novo de manhã, aí recolhe pra almoçá. (JUAREZ, 2007).

Outro fator de escolha para opção do transporte é o destino final do gado. Caso seja um leilão, frigorífico ou engorda em confinamento, provavelmente valerá a pena transportá-lo por caminhão, pela praticidade e para este não perder peso. Até mesmo porque o acesso a estes locais é principalmente, pelas rodovias ou estradas de cascalho. No caminhão a duração da

\footnotetext{
${ }^{79}$ Caminhão que transporta o gado, também chamado de caminhão- gaiola.
} 
viagem será sempre mais curta e isto significa uma vantagem, quando é preciso percorrer grandes distâncias.

O comprador da boiada é o responsável pela organização e pagamento do transporte do gado, deste modo, quando efetuada a compra, marca-se o dia do aparte e a data de saída.

Feita a escolha pela Comitiva de boiadeiros, o fazendeiro ou gerente da fazenda pode solicitar aos seus funcionários que façam a viagem com o gado que comprou, o que costuma acontecer quando é uma Comitiva curta, sendo chamada também de Comitiva de fazenda. Em algumas fazendas, como

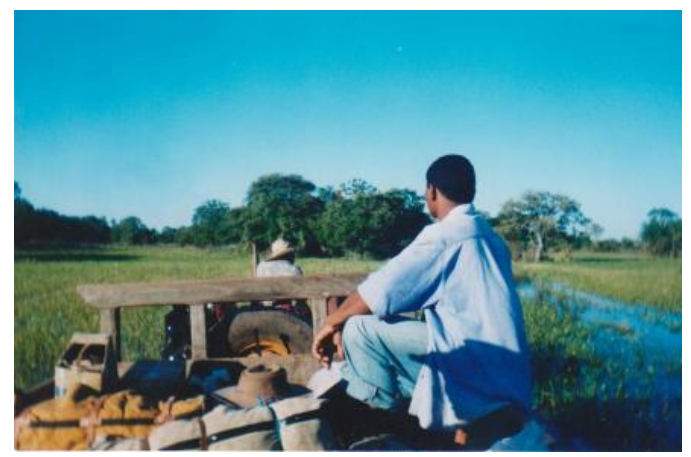

Fig. 35- Sr. Geraldo dirigindo trator até o local de saída da primeira Comitiva acompanhada. Zumba (boiadiero) à direita.

a Estância Caiman ${ }^{80}$, existe uma equipe permanente para fazer Comitivas, podendo fazer longas viagens, mas estes boiadeiros, quando não estão viajando, por vezes, trabalham na fazenda.

Outra possibilidade é a terceirização do serviço através de alguém que contrata as Comitivas, como no caso da terceira Comitiva acompanhada. Uma senhora, Dona Edite, contratava as equipes dando suporte durante toda a viagem, seja levando alimento, transportando-os, ou por outros acontecimentos eventuais, como em casos de adoecimento de boiadeiros.

Porém, é através do Condutor da Comitiva o meio mais comum que os compradores ${ }^{81}$ a contratam. O Condutor 82 ou chefe da Comitiva costuma ter uma equipe de boiadeiros mais ou menos pronta para partir a qualquer momento, além disto, possui todo equipamento necessário, como utensílios da cozinha e a tropa de burros. Nas viagens, os burros são mais utilizados que os cavalos, por serem mais resistentes quando se percorre longas distâncias.

\footnotetext{
${ }^{80}$ Fazenda onde foi acompanhada a primeira Comitiva.

${ }^{81}$ Corretores de gado podem também ser responsáveis pela contratação deste serviço.

${ }^{82}$ Sobre condutores de Comitivas Cf. LEITE, 2003, p. 20 et seq.
} 
Em uma simulação elaborada com auxílio de um pecuarista ${ }^{83}$, se forem levados 1.000 bois em 45 caminhões boiadeiros há uma distância de cerca de 120 km, como da Fazenda São Bento (região do Abobral) ao município de Miranda, esse valor será em torno de R \$ 16.200. Em um caminhão com capacidade para 20 cabeças, cada quilômetro corrido é cobrado em torno de R \$ 1,50. São então, 240 quilômetros. Já se estas mesmas reses forem conduzidas a pé, este custo será em torno de $\mathrm{R} \$ 6.230$ (Tabela 3). Isto significa que um importante fator para se optar pela contratação da Comitiva é que dependendo do volume de gado e da distância, pode ser menos da metade do preço se o gado for tocado.

Este cálculo é feito por marcha (um dia de viagem) e na contratação da Comitiva já se calcula o número destas, a data de saída e de chegada. Nesse trajeto seriam onze marchas, cada marcha costuma ser contabilizada pelo boiadeiro como duas léguas, em média ${ }^{84}$ (cerca de doze quilômetros).

Fontes orais afirmaram que cada marcha vale um salário mínimo 85 (R $\$ 435,00)$, sendo onze marchas, são $\mathrm{R} \$ 4.785$. Deve ser contabilizado ainda, cerca de $\mathrm{R} \$ 435,00$, pois a Comitiva habitua-se a ficar dois dias para preparar/amansar o gado para saída e nesse caso é pago meia marcha (meio salário por dia). Então, somando esses valores chega-se a R \$ 5.520. O comprador do gado deve pagar esse valor ao Condutor ${ }^{86}$, ou "proprietário" da Comitiva.

Normalmente, o dono do gado é quem fornece a carne para consumo alimentar dos boiadeiros, o que foi contabilizado em R $\$ 650$. Durante a viagem levam então a matula (vaca para matar), e se for uma viagem grande, com mais de 30 dias, costumam faián 87 , (falhar)

\footnotetext{
${ }^{83}$ Todos os valores citados foram cotados no mês de julho de 2009.

${ }^{84}$ Légua é a medida mais utilizada pelos boiadeiros. Segundo o entrevistado Barriga, "é 6 km, cada légua".

${ }^{85}$ Valor do salário mínimo em julho de 2009, no estado do MS.

${ }^{86} \mathrm{Na}$ continuação desta simulação foi utilizado apenas o nome Condutor, para facilitar a escrita e por ser o tipo mais frequente.

${ }^{87}$ Faiá ou falhá, é ficar um ou dois dias no ponto de parada. Isto costuma acontecer também quando o gado está fraco.
} 
permanecer um ou dois dias em uma fazenda, para carnear. Algumas vezes também pode ir alguém para abastecê-los.

Se tem arguma fazenda que tem telefone, ele [o Condutor] liga, né, e fala ó eu vô, o cara fala, falhá, eu vo faiá lá em tal lugar. Falhá é que ele vai pousa, vai repetir ali. Eu vô fala, então o que eu vô fazê, eu vô ficá 3 dias pastorejando aqui. Ah ta, ta bão. E o cara, normalmente na viagem, o cara sabe o dia que sai e o dia que chega. Cê conta, nóis vamo vim, nóis vamo pousá nessa fazenda, vamo pousá em tal fazenda, vamo em tal fazenda. Nóis vamo ficá 5 dias trabaiando o gado, ajeitando essa boiada, aí nóis vamo pastorejá em tal fazenda dois dia, então ocê já tem uma conta certa, você entendeu, ocê já tem uma conta certa. Basicamente erra por um dia, dois, no máximo. (JUAREZ, 2009).

Não é o caso desta simulação, entretanto se houver travessia de rio, como o Taquari, é o proprietário da boiada quem a custeia (cerca de $\mathrm{R} \$ 1$ por cabeça).

Continuando a simulação, para esse número marchas e de reses costuma-se levar 22 burros, que ocupam um caminhão, então o comprador deverá pagar R $\$ 360$ pelo frete da tropa de burros.

Tabela 3 - Simulação de custos para o comprador de gado na contratação do serviço de uma Comitiva com duração de 11 marchas.

\begin{tabular}{|c|c|c|}
\hline COMPRADOR & $\mathbf{R} \$ *$ & CÁLCULO \\
\hline 11 MARCHAS & 4.785 & 1 sálario mínimo/ marcha \\
\hline 2 DIAS & 435 & 0,5 sálario minimo/ dia parado (fáia) \\
\hline $1 \mathrm{VACA}$ & 650 & $350 \mathrm{~kg}$ (matula) \\
\hline FRETE DA TROPA & 360 & 22 burros/ caminhão \\
\hline TOTAL & 6.230 & \\
\hline \multicolumn{3}{|l|}{ EXTRAS } \\
\hline TRAVESSIA DE RIOS ** & 1.000 & 1 REAL/CABEÇA \\
\hline
\end{tabular}

Somando-se estes custos, o total pago pelo comprador será em torno de $\mathrm{R} \$ 6.230,00$.

Se considerarmos essa boiada de 1.000 cabeças, como sendo composta de bois magros, com um peso médio de 13 arrobas (390 quilos) / cabeça, o preço da mesma será cerca de $\mathrm{R} \$$ 850,00/ cabeça. Então o valor total desta boiada é de $\mathrm{R} \$ 850.000,00$. “O preço do gado varia 
de acordo com o peso; quando magro, o preço depende da 'caixa', capacidade de peso". (IBGE, 1975:458). Neste trabalho não há tempo hábil para avaliar os custos de produção do pecuarista, o que poderia ser outro tema de pesquisa.

O Condutor recebe o valor das 11 marchas (Tabela 4), mais a marcha pelos dois dias parados na fazenda (RS 5.220) e com parte deste dinheiro, deverá pagar os boiadeiros, que costumam receber por dia de trabalho (diárias). O Cozinheiro e o Ponteiro recebem mais ou menos R\$ 25 por dia (soma-se 13 diárias ou 11 marchas e dois dias, num total de $\mathrm{R} \$ 650$ ). Aos outros componentes paga-se cerca de $\mathrm{R} \$ 20$ por dia, sendo quatro boiadeiros (total de $\mathrm{R}$ \$1.040). Também há despesas com passagens de ônibus para irem até o local de saída, o que inclui cerca 119 reais (se for considerado os sete boiadeiros, multiplica-se pelo valor da passagem- R \$17). Neste raciocínio, o Condutor pagará em torno de $\mathrm{R} \$ 1.809,00$ pela mão de obra.

Tabela 4 - Simulação de custos do Condutor pela prestação do serviço de uma Comitiva de 11 marchas.

\begin{tabular}{|c|c|c|}
\hline CONDUTOR & $\mathbf{R} \$ *$ & CÁLCULO \\
\hline \multicolumn{3}{|l|}{ VALOR RECEBIDO } \\
\hline 11 MARCHAS & 4.785 & 1 sálario mínimo/ marcha \\
\hline 2 DIAS & 435 & 0,5 sálario minimo/ dia parado (fáia) \\
\hline TOTAL & 5.520 & \\
\hline $1 \mathrm{VACA}$ & 650 & $350 \mathrm{~kg}(\text { matula })^{1}$ \\
\hline \multicolumn{3}{|l|}{ VALOR GASTO } \\
\hline 13 DIÁRIAS & 650 & $\mathrm{R} \$ 25 /$ boiadeiro/dia (Cozinheiro e Ponteiro) \\
\hline 13 DIÁRIAS & 1.040 & $\mathrm{R} \$ 20 /$ boiadeiro/dia (2 Fiadores; 2 Meeiros) \\
\hline 7 PASSAGENS DE ÔNIBUS & 119 & $\mathrm{R} \$ 17 /$ passagem de ônibus \\
\hline 7 POUSOS COBRADOS & 385 & $\mathrm{R} \$ 55 /$ pouso $(7 \text { pousos })^{2}$ \\
\hline ALIMENTAÇÃO & 500 & $\mathrm{R} \$ 71,428 /$ boiadeiro \\
\hline ATESTADO DE ANEMIA (22 BURROS) & 440 & $\mathrm{R} \$ 20,00 /$ burro \\
\hline TOTAL & 3.134 & \\
\hline $\begin{array}{l}\text { TOTAL RECEBIDO - TOTAL } \\
\text { GASTO = }\end{array}$ & 2.386 & $(5.520-3.134)$ \\
\hline
\end{tabular}


Além disso, deve ser incluído nos custos do Condutor, cerca de R\$370 reais com pouso, contabilizados com preço médio de $\mathrm{R} \$ 55,00$. Há cerca de quatro pousos que não são cobrados. De acordo com BIGUÁ (2009), "tem em muito boiadeiro que vai pelo centro do Pantanal para não passar no batidão deles que é cruel, cobra mesmo, é 50, 60, 40. (...) [Cobra] por pouso. A gente passa a noite aqui e amanhã vai acertar com o capataz lá”.

Foi calculado ainda, por volta de R\$500 de gastos com alimentação, contando-se oito pessoas.

O Condutor, geralmente dono da tropa, também terá outros gastos com a mesma. Um destes gastos é o atestado de anemia infecto-contagiosa, necessário para viajar com o burro, custando $\mathrm{R} \$ 20,00$ por burro (22 burros serão $\mathrm{R} \$ 440$, com validade de 60 dias).

Dessa foram, o total das despesas fixas do Condutor será por volta de R $\$ 3.134$.

O Condutor só irá receber quando entregar o gado. Caso perca alguma rês, ele terá que pagar ao fazendeiro o valor referente à mesma ou não receberá pelo serviço prestado, a não ser que ocorra a morte da rês. Neste caso terá que trazer o brinco ou a orelha como prova. Apesar de o Condutor receber apenas após entrega, muitas vezes os boiadeiros solicitam o pagamento adiantado, podendo recebê-lo dependendo de sua credibilidade.

\subsection{Puxando a boiada}

As Comitivas de viagem são realizadas por uma equipe de sete a nove boiadeiros, sendo que cada componente possui um determinado ofício. ${ }^{88}$

\footnotetext{
${ }^{88}$ Nogueira (2002) fez uma ótima descrição destes ofícios, portanto seguem apenas alguns complementos mais específicos.
} 
O Condutor é o chefe da Comitiva, sendo sempre o "responsável pelo gado" (JUAREZ, 2007). Por vezes, ele também pode ser chamado de Culatreiro, pois viaja na culatra, posicionado atrás da boiada ou de Comissário: "Comissário é o condutor, né. Comissário da boiada, né. Tem gente que trata de Comissário, né”. (BIGUÁ, 2009)

Próximos ao Condutor estão dois Meeiros (ou Esteiras), que ficam posicionados na lateral direita e na lateral esquerda. À frente de cada um destes estão os Fiadores (um de cada lado). Segundo Juarez (2009), a denominação Esteira "já não usa mais, mas fala, vô fazê um costado, uma esteira aqui, para esses gado não abri." e explica que para fazer esta esteira "forma-se um cordão de cavaleiro ao lado do gado para que ele ande esquadrejado, normalmente onde tem mato, para o gado não correr."

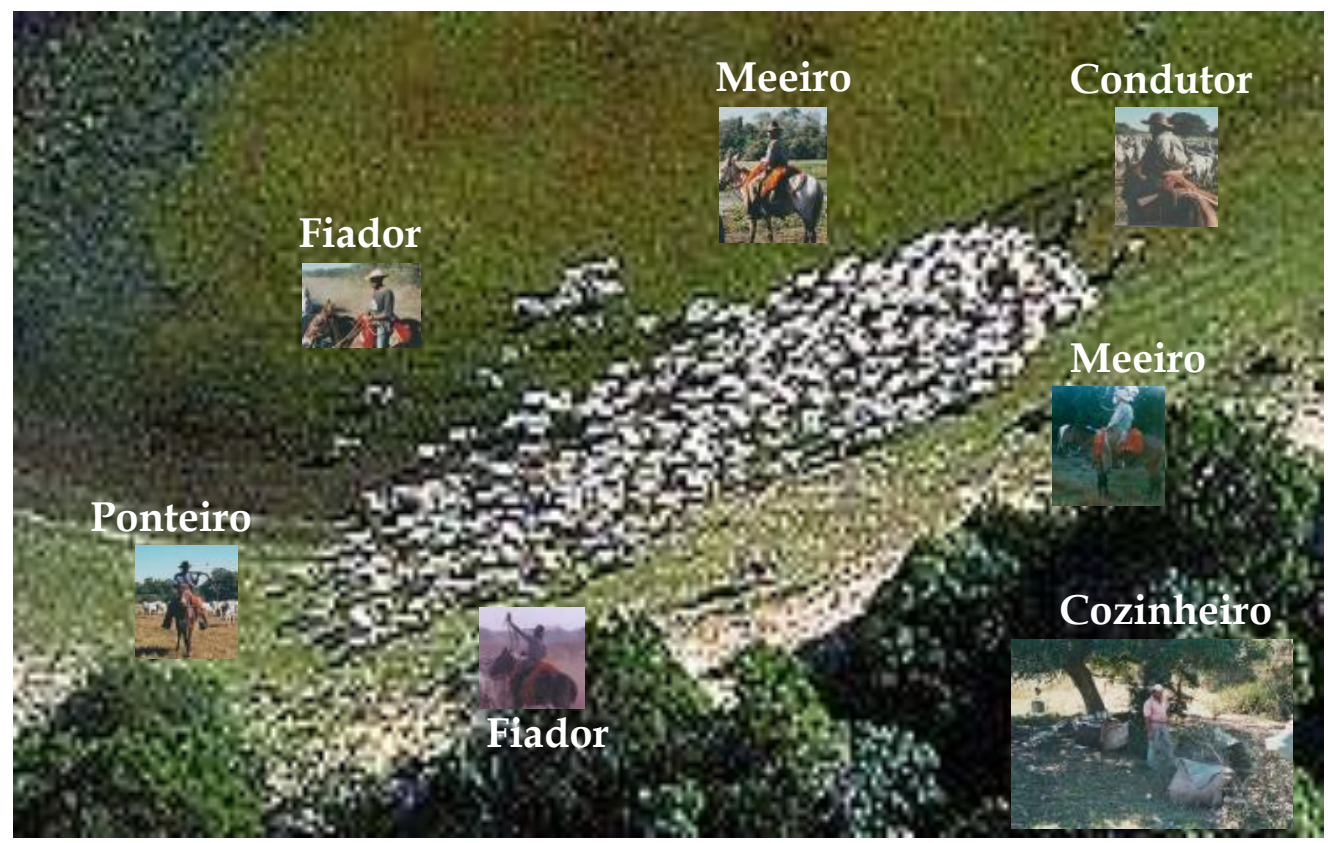

Fig. 36 - Simulacão das funcões dos boiadeiros em Comitiva.

O número dos boiadeiros pode variar de acordo com o tamanho da boiada, podendo haver mais dois Culatreiros, um de cada lado da boiada, que ficam posicionados entre o Condutor e cada Meeiro. Isto acontece geralmente, quando há necessidade de conduzir mais de 1.000 cabeças. 
O Meeiro também pode ser chamado de Culatreiro ou Culateiro, quando precisa ficar mais atrás da boiada, como, por exemplo, durante a condução de boiadas em corredores ${ }^{89}$ de gado.

Tanto Meeiros, quanto Fiadores "têm a responsabilidade de não deixar gado abrir ou entrar para o mato" (NOGUEIRA, 2002, p. 109). Segundo alguns boiadeiros, a boiada tende a abrir do lado de quem é mais preguiçoso, mas certo é que não podem apertá demais, nem abrí demais. Para tal, os boiadeiros ficam posicionados ao lado direito da boiada têm sempre que estar atento de modo a equilibrar a intensidade da condução (apertá ou abri) com aqueles do lado esquerdo.

Você sabê conduzi o gado, né, sabê fazê sua parte, num, na viagem não é só pegá o gado e ir empurrando o gado, cê deixá o gado pastá, um pouco assim, ocê sabe mais ou menos a hora que o gado for abrindo um pouco assim, você vai lá e joga o gado um pouquinho pro lado do Ponteiro assim, o gado já sabe, vai virando já, num dexá ele abri muito assim, tem muita gente que não sabe, ele, o gado vai pastando e vai folgando, assim quando você vê o gado já esparramô tudo aí. Já é mais difícil procê... (BARRIGA, 2009).

Quando os boiadeiros estão em corredores de gado, a forma de conduzir se altera,

podendo facilitar o trabalho, mas ao mesmo tempo, exigindo novos cuidados.

Não, o Meeiro fica com o Condutor, aí ele fica na culatra. (No corredor vão 3 na frente e 3 atrás. (...) fica fixo). Por isso que eu falo pra você, despois que saiu essas coisa agora, tá bom de viajar, porque o peão não tem muita preocupação, não, porque antes era tudo aberto, então tinha que ir do lado, tinha que organizá a boiada, tinha que esquadrejá (exemplo, mantém dentro do quadrado) a boiada, né. Eu trabalhava direto nisso aí, ia e voltava. Se sai de tráiz, vai lá no meio da boiada e volta, vai lá no meio e volta. Quem ta na frente, na lateral, que fala Fiador, vem até no meio de onde ocê ta e volta, vem até no meio onde cê ta e volta, então a boiada tem que ir esquadrejada. Se pega, por exemplo um corredor sujo de mato, tem que ir devagarzinho, tem que olha se não tem caminhão parado na beira, por exemplo atrás. E na frente, e os Fiador que vai na frente tem que ir olhando se não tem um vão, uma rabada, se ele não ver, e o gado for ali coxeando a cerca, ele vai vará, porque ta bom de pasto pro outro lado, aí ele vai querer varar, varar, onde que ele extravia, e perde e tem todo um trabalho depois, de ta voltando, pra ir atrás, é complicado. (...) pra você trabalhar, pra você desgastá, cansá, até você como o animal descansa muito, hoje, é mais, mais tranqüilo. (JUAREZ, 2007, 2009).

\footnotetext{
${ }^{89}$ Ver sobre corredor, na Tabela 05, p. 127.
} 
O Ponteiro posiciona-se à frente da boiada, vai na "guia". Está sempre com o berrante, instrumento feito do chifre do boi que é tocado para auxiliar na condução da boiada e para comunicação entre os membros da equipe.

Só o Ponteiro que carrega o berrante. (...) O berrante é o Ponteiro que tem que tê. Pra ele aprendê também, a hora que o Ponteiro saiu do mangueiro, antes de sair do mangueiro toca o berrante assim, pro gado já, acostumá com o berrante, já vai acostumando, já levanta já, se tá deitado já levanta, que é pra saí. E cada passada de portão assim, se o, se o passador, assim, vai passar o portão, o Ponteiro toca o berrante, pra, pro gado já atravessá, e o pessoal já sabe que é pra atravessá ali, a cerca ali. E na encerra também, de tarde, ele toca o berrante e o gado já sai no corredor pra ir pro mangueiro. Talveiz o, é tudo combinado assim, o Ponteiro tocá o berrante pro chama o Fiador do lado, eles toca. Aí o, aquele fiador, de esquerda, que trabalha, já sabe que tá chamando ele pra frente. Se ocê tocá de outro jeito, tem outro toque, ele chama o, que trabalha na direita pra, já sabe já. Então ele, talveiz já tá meio sabendo já na hora, pra andá, toca o berrante o pessoal já sabe que é pra í já pra frente. (BARRIGA, 2009).

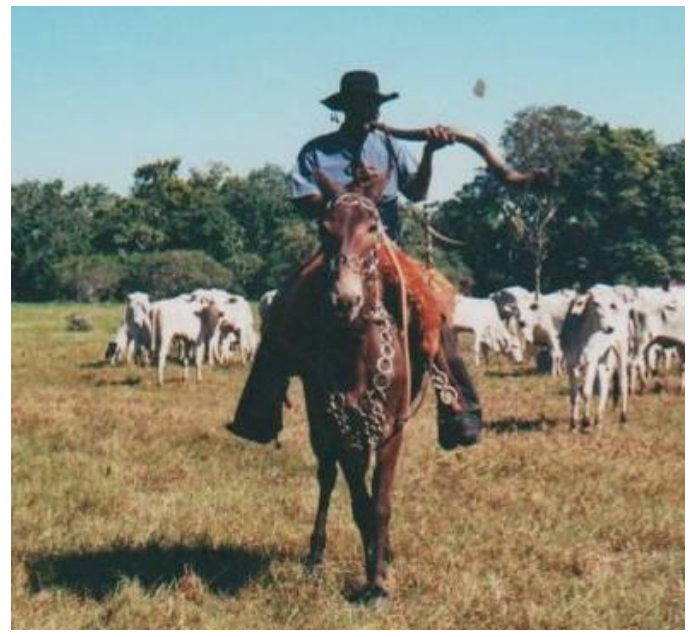

Fig. 37- Ponteiro Luís tocando o berrante. Terceira Comitiva.

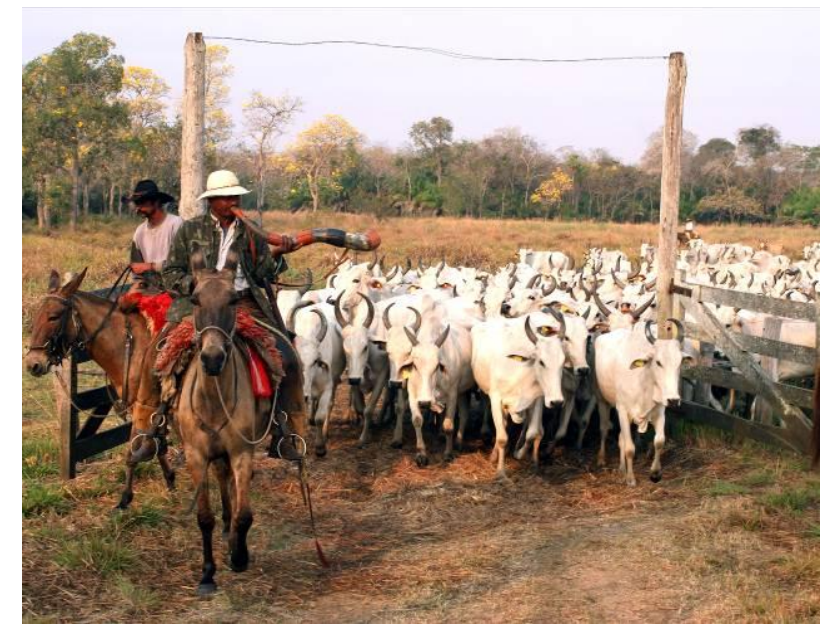

Fig. 38. Ponteiro Morcego na Comitiva Fazenda Caiman ( 2005). Fonte: Thiago Rocha.

Além disso, ele precisa saber o caminho, pois é quem o indica, "é o cara da frente que leva o gado na direção que ele quer". (JUAREZ, 2007). "Ele tem que sabê as dobradas, porque senão ele tá enrolado”. (BIGUÁ, 2009).

É o Ponteiro que é responsável pelo gado na frente e o Condutor é responsável por tudo, né. O Ponteiro se fala, nóis vamo aqui, você tem que obedecer o Ponteiro, né. Se ele coloca a cara, você tem que ir. (BARRIGA, 2009)

Se ele errar, todo mundo vai errar também, só se o outro, se num conhecê, o outro, passa informação pra ele. Vamo aqui, vamo ali, vai tranquilo. Mas o Ponteiro aprende a conhecer os caminho tudinho, fala, os desvio, os atalho, né. Então, vamo tira, vamo tira um atalho, né, o cara fala. Então ele sabe que a estrada vai aqui, mas se ele for aqui ele vai sair lá na frente. (JUAREZ, 2007). 
Durante as Comitivas acompanhadas, vários boiadeiros disseram que o ofício mais perigoso é o do Ponteiro, pois se o gado estourá (correr assustado) pode passar por cima dele. Apesar desta colocação, o perigo está presente entre todas as funções. Quando o gado estoura, ou mesmo se é um gado arisco ou esperto que consegue fugir, ele é recuperado pelo arribador (NOGUEIRA, 2002). Assim, o Condutor irá escolher, dentre os boiadeiros da Comitiva, quem será o arribador, mas segundo alguns boiadeiros, no geral, deverá ser o Culateiro ou Meeiro.

Se ocê sai com uma boiada, aí, no primeiro dia, ela corre, estoura de você,, dá um trabalho pra você juntar, reunir ela de novo, sair, depois de 5 dias, você vai vê ela, você num conhece, num fala que é a mesma boiada. Vai fácil... (JUAREZ, 2007).

Em Julho de 2009, alguns moradores na região do Abobral relataram que um boiadeiro estava na trabalhando na fazenda Nossa Senhora de Fátima, quando foi pisoteado por uma boiada que estourou, tendo fraturado costelas e perfurado o pulmão. Há vários destes relatos sobre acidentes com boiadeiros e além de ser um trabalho de risco, dependendo do local pode haver ainda dificuldade de serem socorridos. ${ }^{90}$

À frente do Ponteiro sempre fica a tropa de burros, a qual de acordo com os pontos de parada é substituta de montaria, ocorrendo um rodízio de trabalho. Dependendo da distância da viagem e do número de cabeças de gado, são cerca de 22 burros amadrinhados (guiados) pelo polaqueiro $^{91}$. Normalmente, este é um cavalo petiço (pequeno), e segundo relatos dos

\footnotetext{
${ }^{90}$ No segundo dia de viagem da primeira Comitiva acompanhada, à margem de uma estrada de terra, um carro, mesmo em baixa velocidade, assustou a boiada e esta estourou. A cena era aterrorizadora, o caminho estreito, sujo (com mata fechada) e de repente, cerca de 1.000 cabeças de gado viravam a cabeça, corriam e retornavam em direção aos Culatreiros, os quais sumiram no meio da mata, tentando recuperá-las. Como a pesquisadora também estava nesta direção, a única coisa que pode-se fazer foi tentar ajudar a segurar a boiada, até porque não tinha como sair da frente da mesma. Então, por alguns instantes abanava o chapéu e gritava: Vira! Vira! Por sorte, a pesquisadora também consegui ajudar, mantendo parada boa parte da vacada. Porém, quando chegaram no ponto de almoço, o Condutor contou a boiada e faltavam cinco reses. Neste caso, ele próprio foi o arribador e finalmente conseguiu recuperá-las, chegando ao pouso um pouco mais tarde.

Outro acontecimento que pode exemplificar este tipo de situação foi o acidente a cavalo da pesquisadora, durante o trabalho como guia de ecoturismo. Quase no final de um passeio a cavalo, este empinou caindo sobre suas costas e fraturando uma de suas vértebras. Apesar de estar próxima da pousada, com fácil acesso a veículos, o socorro foi complicado, levando 5 horas para que chegasse ao hospital. Assim, é possível então, ter uma idéia sobre uma das dificuldades dos boiadeiros, pois costumam viajar por lugares remotos, com precariedade de acesso e comunicação, além da pouca infra-estrutura para serem socorridos.

${ }^{91}$ Costuma ser um cavalo manso e mais experiente que guia a tropa de muares. Carrega um polaco (sino) pendurado ao pescoço.
} 
boiadeiros são utilizados apenas como guias da tropa, pois sendo muito pequeno não dá nem para por traia, quer dizer, não dá para encilhar e utilizar para ser montado.

Um fenômeno muito interessante observado é a técnica tradicional ${ }^{92}$ de contagem dos bois pelo Condutor (Fig. 39). Isto ocorre todos os dias, pela manhã, podendo recontá-las

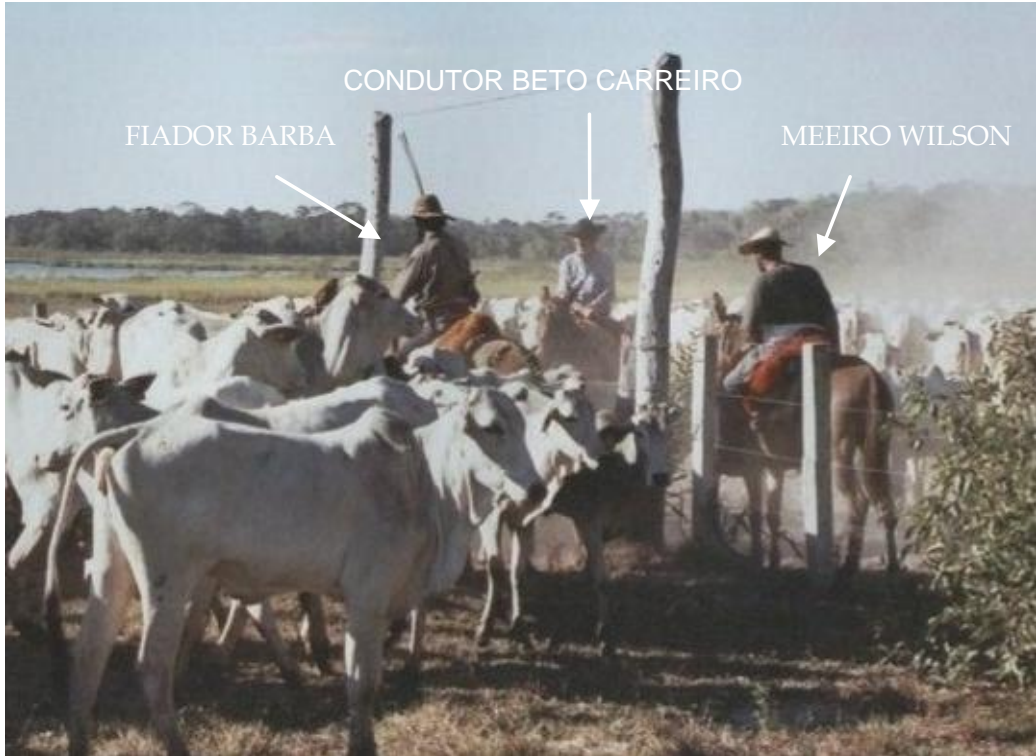

Fig. 39 - Contagem de bois pelo Condutor. Terceira Comitiva. no almoço se houver desconfiança de terem perdido alguma rês pelo caminho. Montado em seu burro, o Condutor fica posicionado na saída do portão de onde se encerrou $^{93}$ o gado na noite anterior, enquanto os

\section{Culateiros costumam ficar}

posicionados um de cada lado, anteriormente ao mesmo portão. Estes têm a função de falar com a rês de forma que saiam calmamente, afunilando-as no portão e assim, facilitar a contagem ou como dizem, para afinar o gado (fazer com que saiam em uma fila mais estreita).

Neste momento, há um silêncio marcante dos boiadeiros, somente escuta-se o barulho do pisoteamento da boiada e sente-se a poeira que levanta chão. Segundo relatos a habilidade em contar o gado tem que ser muito precisa, pois se faltar alguma rês o Condutor terá que pagá-la. Por meio da conversa com alguns Condutores sobre como é feita esta contagem, foi dito que o principal para contá-la é ter concentração.

\footnotetext{
92 Entende-se como técnica tradicional aquela que é passada através da imitação, mimese, pelo emprego de materiais que definem em primeira instância o tipo de trabalho. Tendem a permanecer fixas no tempo, só cabendo aos mestres consagrados a tolerância de variações. Ao mesmo tempo caminham-se para regionalismos. Difere-se das técnicas modernas, por estas últimas estarem vinculadas à escolaridade e especialização, dependente das ciências contemporâneas. Katinsky (1967 apud FERNANDES, 1997: 24).

${ }^{93}$ Encerrar o gado é colocá-lo no mangueiro (curral), também se diz fechar o gado.
} 
A forma de contagem pode variar, mas de acordo relatos dos Condutores, mantêm-se as duas mãos abertas e para cada 50 reses que atravessam o portão, dobra-se um dedo da mão, o que se chama uma taia ou talha. A cada dedo dobrado a contagem é reiniciada e assim por diante, mantendo cada dedo nesta posição até chegar ao ponto de se estar com todos os dedos dobrados, simbolizando o número 500, nesse caso seriam 10 talhas. Havendo mais de 500 cabeças, abrem-se as mãos rapidamente, memorizando estas 500 e a contagem nas mãos reinicia-se. Alguns Condutores, ao invés de dobrarem os dedos, utilizam-se de palitos de fósforo ou pequenos galhos, que simbolizam cada talha. Por exemplo, uma das mãos fica cheia de palitos e a cada talha contada passa-se um palito para a outra mão. No final da contagem estarão com o número total de bois, representado em palitos.

Como experiência tentou-se por diversas vezes fazer esta contagem e não houve sucesso, assim, notou-se que além da concentração há dificuldade em não contar uma a rês mais de uma vez, pois às vezes elas estão caminhando na direção da saída, mas por algum motivo retornam. Além disso, apesar dos Culateiros terem a função de acalmar as reses, por vezes elas passam muito rápido pelo portão.

Alguns Condutores colocaram que para não se atrapalhar contam a rês somente no momento que a cabeça da mesma está passando pelo portão, deve-se projetar lateralmente ao portão uma linha imaginária, para se ter uma referência fixa. Estes parecem contá-la com facilidade.

No que se pode perceber a relação entre Condutor e os outros boiadeiros (patrãoempregado) é mais próxima, mais solta do que se for comparado à relação gerente ou pecuarista e peão de fazenda. Apesar de haver uma hierarquia no trabalho, a opinião do boiadeiro é mais presente nas decisões necessárias durante as viagens, principalmente se há algum boiadeiro experiente. As brincadeiras também são mais freqüentes entre os últimos. 
Outro ofício exercido pelo boiadeiro é o de cozinhar, sendo este chamado de Cozinheiro ou Cuca. Segundo o Cozinheiro Biguá (2009), eles também podem ser chamados de Mão Pelada: “Cuca tem gente que chama Cuca, Mão pelada, né. Mão pelada também, por que, por causa do mão pelada, das labaredas que queima os cabelo da mão da gente”.

Diferentemente de todos os outros boiadeiros citados, o Cozinheiro não acompanha a boiada. Vai à frente junto com a tropa de cargueiros, que carregam nas bruacas, os mantimentos e os dobros. Segundo Nogueira (2002, p. 110), o Cozinheiro é aquele que "serve a bóia”.

O Cozinhero, essa turma fala que não, mas pra mim é o que mais sofre. E o Cozinhero é o primeiro que levanta e o último que dorme, deita. Ele, e é uma regra, se o Cozinheiro gritar pra você, quatro hora, ele grita: ó moca. Num é café que ele fala, eles falam moca. Ó moca gurizada. É. Aí ele dá a média de uns 5 minutos pra você ta ali tomando café. Se ocê quisé durmi, e num levantá e num se virá e num vim toma café, ele joga fora. Você pode viajar quantas vezes, mas você chegando na cozinha dele, na frente dele, ele pegá um bule assim, e balança assim, joga fora, ocê num pode falá nada. Porque aí se ocê tá com mau humor, problema seu. Se ocê perdeu a hora, problema seu. Porque ele tem todo um compromisso, ele tem que lava aquela vasilha que ele desencaixotou, tem que secar aquela vasilha, encaixotar tudo de novo. Espera as trempe dele esfriá, desmonta ela, puxa fora do fogo, esperar ela esfriá porque ele tem que encaixotar ela, por no tipo arforge de couro, que márra, que leva, pra ele ir viajá. Então quando ocê, enquanto ocê tem que só tomá o café e pega teu cavalo pra encilhar, ele tem que levantar antes, fazê o fogo, fazê o café, tirar tudinho dali, esperar esfriá, encaixotá, quando ocê for pegar o animar ele tem que tá pronto também pra ir pegar o dele. (...) é demorado, normalmente é quatro burro, pra ele ter que carregá os quatro, então são oito caixa, é muita coisa, ele tem que arrumá... (JUAREZ, 2007).

O entrevistado Biguá exerce o ofício de Cozinheiro de Comitiva há mais de 30 anos.

Descrevendo sobre sua função colocou que costuma acordar entre quatro e meia e cinco horas da manhã, "levanta madrugadão, né (...) ai você faz tudo tranquilo”, mas isto irá depender também do comando do Condutor. Alguns não gostam de acordar tão cedo e quando acontece, costumam dizer para o Cozinheiro: "o cunhado, se vai pegá malhada, que vai fazê". Cunhado é uma forma de chamarem uns aos outros, principalmente quando querem brincar com a pessoa e malhada é nome do lugar onde o gado dorme, significando encontrar a vaca ainda dormindo. 
O Cozinheiro, tanto no ponto de almoço ou pouso é quem encilha e desencilha a tropa cargueira, organizando em cima do lombo destes burros as bruacas (que contém os objetos de sua cozinha) e as malas dos boiadeiros, chamadas de dobros (Fig. 40 à 43).

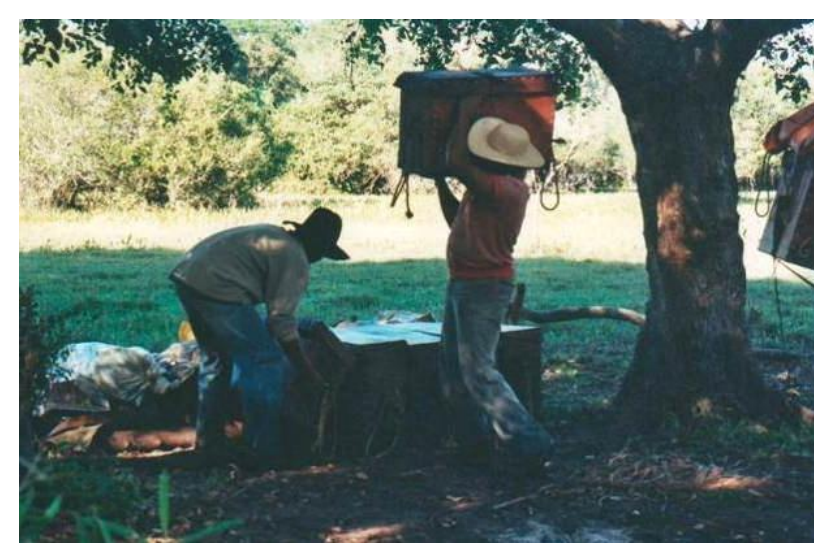

Fig. 40 - Acompanhador de fazenda e Cozinheiro Dourado.

Os boiadeiros só costumam abrir seus dobros no ponto de pouso, e antes de pegá-la sempre pedem permissão ao Cozinheiro. Segundo informantes, durante o encilhamento da tropa é necessário que o peso sobre cada lado do lombo do burro seja distribuído equilibradamente, para não pisá, machucá-los, podendo cada burro carregar por volta de 45 quilos em cada lado.

Normalmente, sempre sozinho, quando é, o gado é manso, e coisa e tão num lugar bom, sempre o Condutor deixá um pra ajudar ele, mas mesmo assim, ainda sai por último, porque os cara chega, pega ali o animal junto com ele, encilha, e já vai pro mangueiro, e do magueiro já soltando. Então ele tem que encilhar os 4 burro e ainda encilhar o dele. Aí o que que ele faz, ele encilha o dele, puxa o dele pro lado, ai ele vai encilhando os outro, porque cada burro tem a sua carga certa de carregar, entendeu? Os mesmo baixeiro, o mesmo tilim, por a mesma carga. Por exemplo, se ele chegou hoje, ele um pacote de macarrão, um quilo de arroz na janta, ele já tem que saber da onde ele, que caixa ele tirou, pra ele igualar o peso, porque a caixa tem que ta sempre o mesmo peso, $10 \mathrm{~kg}$ prum lado, $10 \mathrm{~kg}$ pro outro. Pra ele ir no balanço, pra não pisar o animal. Se pisá, tem que viajá. Então é uma coisa muito melindrosa, tem que ter muito cuidado, muita atenção. (Pra encilhar põe baixeiro com a manta e o arreio, mais uma chincha. Aí as bruaca. Aí coloca as malas dos peões - os dobro). Joga-se um couro de vaca por cima do couro, o tilim, onde já tem uma chincha. (JUAREZ, 2007, 2009). 


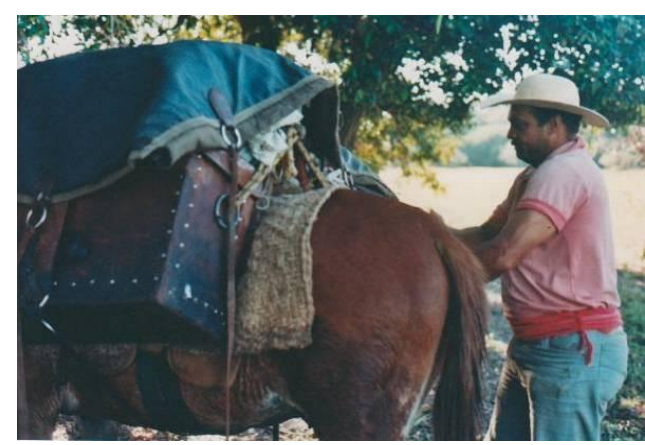

Fig. 41 - Cozinheiro Dourado encilhando Fig. burro cargueiro (bruacas em baixo, cargueiro dobros dispostos sobre a mesma e lona Comitiva para cobri-los).

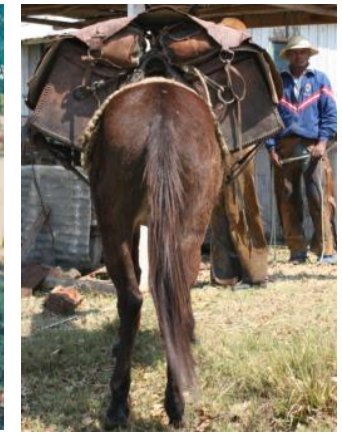

42- Burro encilhado.

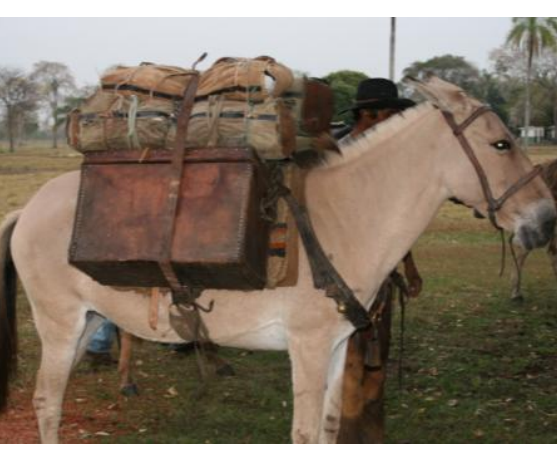

Fig. 43- Mula cargueira encilhada. Comitiva Caiman. Fonte: Thiago Rocha.

No cotidiano, os boiadeiros costumam acordar antes de o sol nascer, tomam o mate ${ }^{94}$, e/ou um café e preparam-se para a saída. Desfazem o acampamento, retiram-se as redes e os mosquiteiros, que são guardados em seus dobros.

Segundo Barriga, “ocê saí com o gado e vai pousá na outra fazenda. Cê sai cedo, encilha os cavalo, cê levanta, arruma o, a mala, e ai ocê vai pegá os cavalo seu, o burro, porque anda mais no burro, né.

Enquanto isso, um dos boiadeiros deve tocar, pegar, a tropa para que esta seja encilhada. Para tal, é feito um revezamento entre os boiadeiros, cada dia é um boiadeiro que exerce a função de peão tropeiro. Assim explica Juarez (2009):

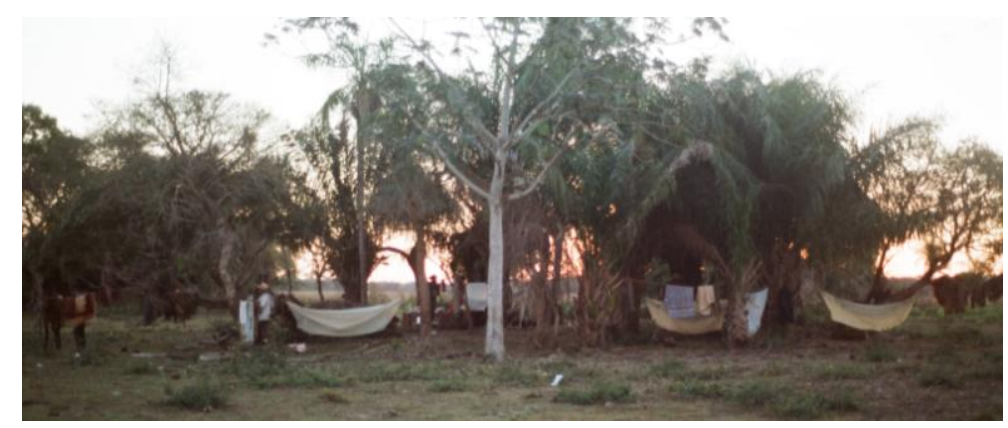

Fig. 44 - Ponto de pouso Fazenda Buriti. Terceira Comitiva.
Porque pra começar você levanta numa média de 3 horas da manhã, ocê acorda aí ocê tem todo um trabalho antes de ocê encilhar teu animal, ocê tem todo um trabalho, no que você tá dormindo ali, ocê tem que recolher tudo, colocá tudo bem arrumadinho dentro do dobro $e$ entregar pro Cozinheiro bem arrumadinho, né. Aí, cedo você não

come, só toma um café, antes de clareá o dia ocê toma um café, tipo 5 horas, já ta querendo clarear, ocê já tomou seu café e já ta com seu buçal na mão pra ocê pegar seu animar (....) Aí o cara toca a tropa, o peão tropeiro. Cada dia é dia dum, entendeu, cada dia um toca a tropa. Aí ocê,o cara vem, o cara vai tocar a tropa, o cara tem que dar água pra tropa antes de trazer a tropa pra você encilhar. (...)Aí ele tem que levar lá a tropa a pé, dá água e trazer, porque a tropa costuma tomar água só quando leva. Aí você encilha, aí você sai. (JUAREZ, 2007).

\footnotetext{
${ }^{94}$ Esta bebida foi descrita na p.85.
} 
Após o peão tropeiro tocar a tropa, é feita a forma. Isto é, a tropa é orientada pelos boiadeiros para se posicionar em um local orientado pelo peão, de forma que esta fique organizada em fileira (Fig. 46). Cada componente coloca o buçal ou a cabeçada (freio e buçal) em sua montaria. Quando todos terminam de colocá-las, o primeiro peão da ponta de um dos lados começa a puxar seu animal, ocorrendo o mesmo com cada peão em sequência, para levá-los ao local onde estão as tralhas e serão encilhados.

E então, "você vai sortá o gado" (BARRIGA, 2009). Só irão parar quando estiverem no ponto de almoço, onde o Cozinheiro os espera. Quando chegam, já está tudo pronto. Então almoçam e partem para nova jornada, que segue até o ponto onde irão pousar.

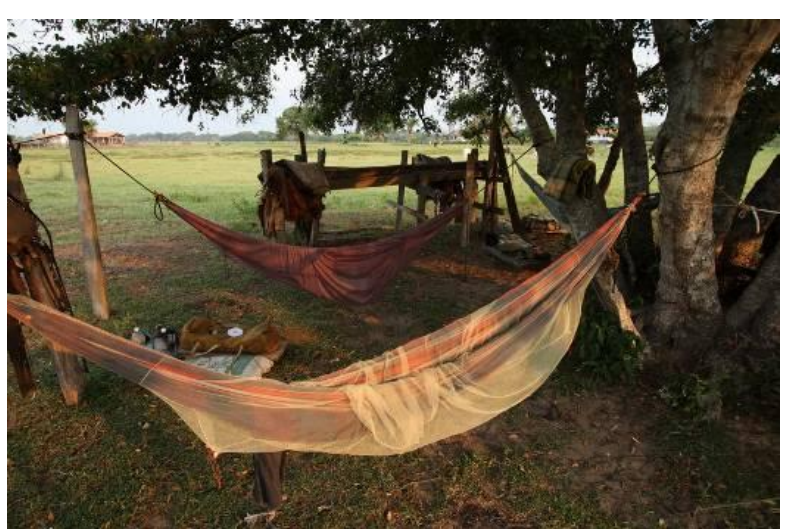

Fig. 45 - Ponto de pouso. Redes armadas. Fonte: Csaba Gődény.

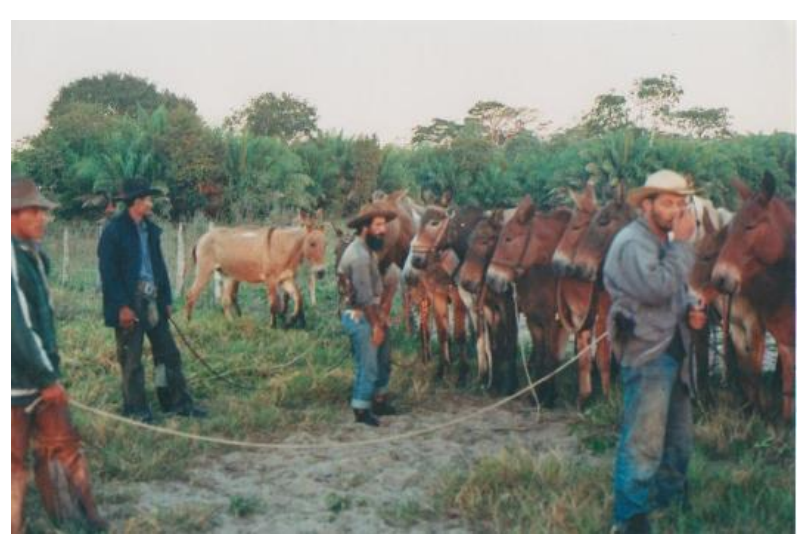

Fig. 46. Tropa "formada" (em fila organizada) para ser encilhada.

O Cozinheiro deve chegar à frente nos pontos de pouso e almoço e então, procura o capataz da fazenda pedindo permissão para arrumar o acampamento, a não ser que o ponto esteja em um lugar muito afastado da sede ou retiro. O capataz então indica o lugar onde se deve ficar. Assim, conta Rondon (1996 apud FERNANDES, 2002, p.319): “Aí chegamos lá no lugar do pouso. Aí fomos lá, pedimos pouso pro encarregado. Ele deu o pouso pra nós, mandou nós parar distância de uns trezentos metros longe da sede, mais ou menos". 


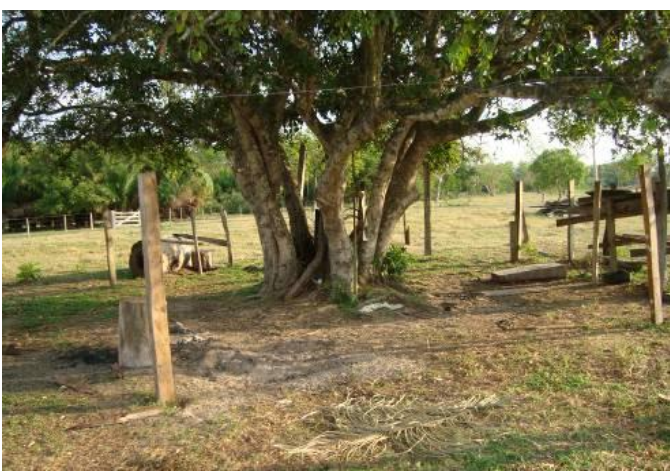

Fig. 47 - Marcas dos boiadeiros em ponto de parada (cinzas e postes para redes).
Foi percebido que todos os pontos de parada são fixos, quer dizer, as Comitivas param nos mesmos lugares. Isto é visível, pois costuma haver pelo menos troncos de madeiras fincados no chão, onde os boiadeiros armam suas redes e restos de cinzas das lenhas queimadas para cozinhar (Fig. 47).

A cozinha é sempre organizada pelo Cozinheiro, tanto no ponto do almoço como no pouso. É um dos elementos mais interessantes durante a Comitiva, sendo observadas diversas regras de convívio social, que estão relatadas a seguir.

Apesar de parecer improvisado, pode se notar que a cozinha é organizada, limpa e a comida é bem feita. Segundo o entrevistado Biguá (2009), não havendo nenhum imprevisto, costuma-se chegar ao ponto de almoço:

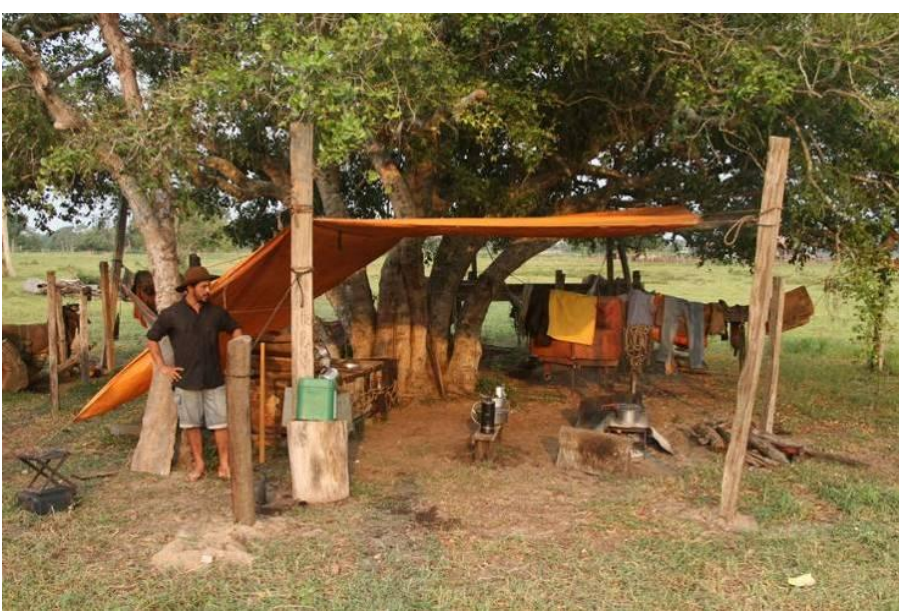

Fig. 48 - Cozinheiro e sua cozinha. Fonte: Csaba Gődény
Oito, nove hora, por ai, é essa média, aí se faz o mais difícil primeiro, né. Cê vai fazê uma carne com macarrão, porque o arroiz é rápido, ne. Cê escuto o movimento, aí cê fritô o arroiz, já põe uma água ali, a hora que a turma chega pra almoçá o arroiz já tá bom. De tarde, a hora que eu acendê o fogo (...) a hora que eu começo a fazê a comida, o feijão já tá cozinhando. Lavo todas as vasilha de noite, ai já encaixoto elas. Enquanto a turma toma o café, eu já lavo as vasilha, enquanto tá baixando a janta. Mais cedo atrapalha a gente.

Não é muito comum, entretanto se pela manhã, for servido um carreteiro (arroz, carne seca e temperos, como alho, sal e cebola) costumam chamá-lo de quebra torto “(...) na Comitiva você não toma chá, chá é o quebra torto de manhã, né." (BARRIGA, 2009). Se for servida a comida que sobrou do jantar passado, os boiadeiros chamam de véio, "a comida que sobra da janta, fala véio, que você esquenta de manhã”. (BIGUÁ, 2009). 
O sentido para servir-se da comida é de acordo com a seta apontada na figura 49 , sendo que não é permitido voltar pelo sentido oposto. Foi percebido também que, principalmente, os mais velhos utilizam este sentido para armarem suas redes nos pontos de pouso, e alguns destes preferem dormir com o pé apontando a direção do roteiro da Comitiva. As redes são armadas com mosquiteiros que protegem tanto de insetos quanto de cobras, estas últimos são as mais temidas pelos boiadeiros.

Vários informantes confirmaram que a sequência das panelas deve ser feijão, arroz carreteiro e macarrão tropeiro. Muitas vezes pode haver apenas os dois primeiros, mas costuma-se ter fartura de carne. Os temperos principais utilizados são alho, sal e cebola. Para o macarrão, além destes temperos e da carne seca é usado um pouquinho de extrato de tomate, que quase não chega a colorir o macarrão.

Observou-se que o material das panelas, latas de água e talheres costumam ser de alumínio, já as canecas, xícaras e pratos são esmaltadas. As bruacas são feitas com armação de madeira, revestimento de couro e pequenas tachas de metal.

Em algumas ocasiões os boiadeiros compram alimentos nas fazendas que estão passando, tais como queijo, óleo, ou também ganham dos moradores destas fazendas mandioca, abóbora, frango, porco, carneiro, e assim podem variar as refeições.

O porco monteiro ${ }^{95}$ também é uma espécie apreciada pelos boiadeiros, podendo ser caçado, de acordo com a oportunidade, mas não é um hábito comum. Não foi observado que os boiadeiros consumam algum outro tipo de caça, mas segundo fontes orais, algumas poucas vezes podem também caçar queixada (Tayassu pecari). Em nenhum momento ouviu-se sobre a caça de outras espécies, senão estas.

\footnotetext{
${ }^{95}$ O porco monteiro é uma espécie introduzida no Pantanal por volta do século XVIII. É atualmente, a forma feral (que retornou ao hábitat selvagem) do porco doméstico (Sus scrofa). (FURTADO, 2009). Apesar de ser uma questão polêmica, está protegido pela Lei de crimes ambientais, n $^{\circ}$ 9605/98, $\S 3$ do art. 29, sendo considerada pertencente a fauna silvestre por ter todo seu ciclo de vida dentro do Pantanal.
} 


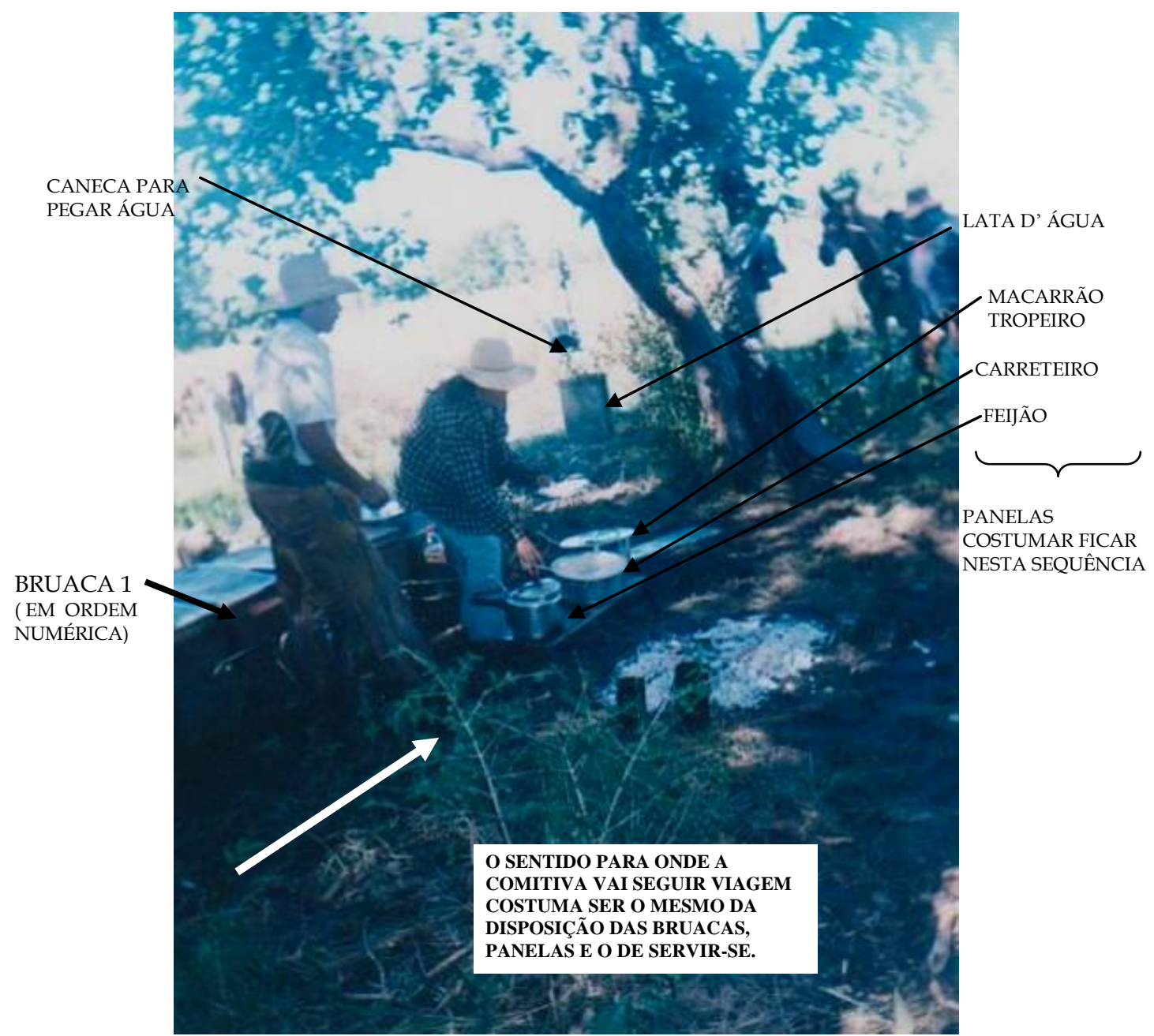

Fig. 49. Organização da cozinha. Pesquisadora e Ramon Miranda.

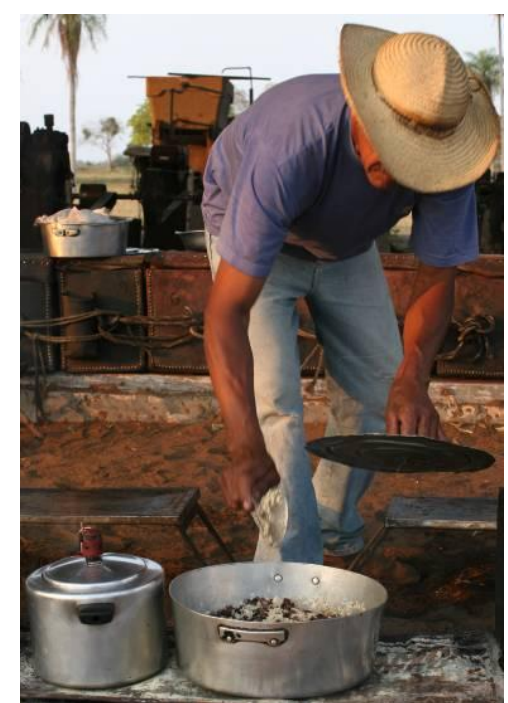

Fig. 50 - Cozinheiro Gilberto preparando arroz carreteiro. Comitiva Caima. Fonte: Thiago Rocha (2005)

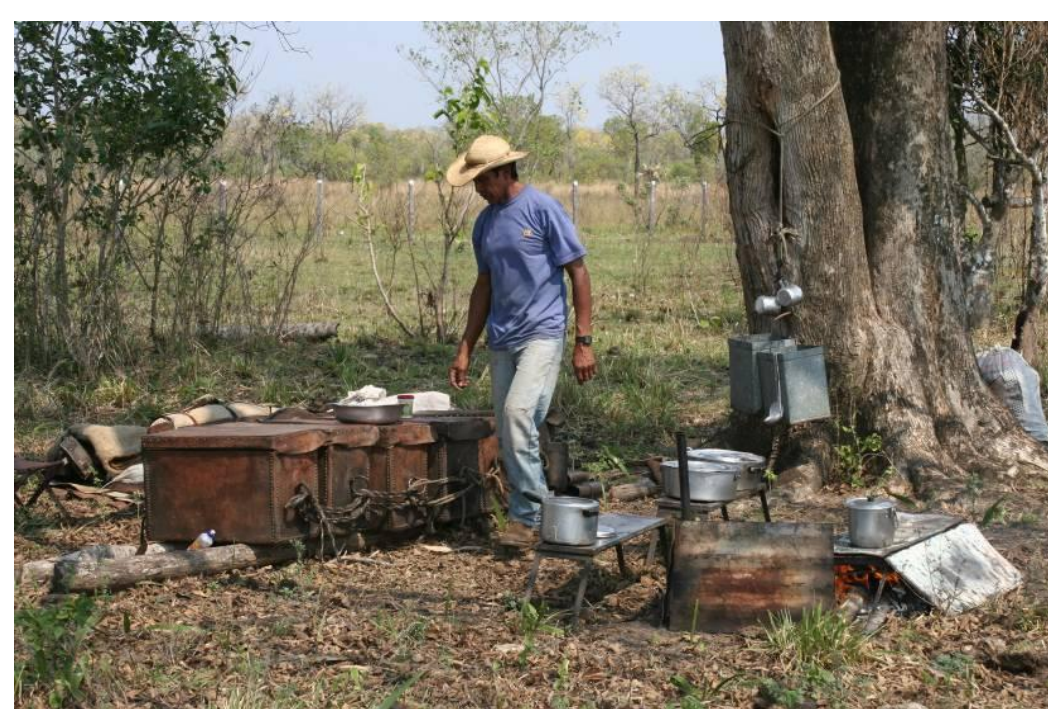

Fig. 51 - Cozinheiro Gilberto preparando almoço. Comitiva Caiman. Fonte: Thiago Rocha (2005)

O boiadeiro para servir-se da comida deve sempre estar vestido de camisa e chapéu.

Deve ainda entrar pelo lado indicado (Fig. 49 a 51), pegar a tampa da primeira panela 
disposta, com a mão esquerda, junto com seu prato e com a mão direita irá pegar a colher para servir-se. E assim por diante. Se qualquer um destes objetos cair ou se esquecer do chapéu ou da camisa deve-se compensar o erro, comprando-se um frango na fazenda mais próxima e dar aos outros boiadeiros. Preferencialmente, paga um frango, mas se não houver frango, pode ser qualquer outro alimento como porco, mandioca ou queijo.

E tem a regra também de tirar comida na hora do ponto de almoço, de o peão chegar na hora que tá pronto o almoço, lá no ponto de almoço, sesteado, ele num pode tirar o chapéu, porque se ele tirar o chapéu,ele paga um frango no outro pouso, A pessoa tem que pagar um frango, Chega lá, o Cozinheiro já vai lá e compra um frango na fazenda. Aí ele no final da boiada já desconta na conta do peão, tem que pagar o frango.

Tem muita regra, o Cozinheiro fica lá só buringando lá, num pode tirar o chapéu e também a tampa da panela num pode tirar de uma vez. Destampar, tem que segurar cum uma mão aqui o prato, tirar a comida dali, tampar. E tem tudo isso a regra. RONDON (1996 apud FERNANDES, 2002:318).

Após comerem, não se deve deixar resto algum. Pratos e colheres (costumam usar apenas colher) devem ser colocados em um local indicado pelo Cozinheiro, o qual irá lavá-los após todos terminarem. O café é servido pela manhã e após o almoço ou janta.

As xícaras de café ficam dentro de uma panela com água fervida e para pegá-la deve-se usar uma colher de concha ou um arame retorcido na ponta, que fica dentro da mesma (Fig. 53). Depois de tomar o café deve-se lavar a xícara, segurando-a pela alça, pegar um pouco desta água e jogá-la no chão, e então a xícara pode ser novamente colocada na panela.

As canecas para tomar água ficam ao lado de duas latas d'água penduradas em um tronco de árvore (Fig.54). Uma caneca maior, pendurada em uma das latas serve para pegar a água (segurando-a pela alça). Faz-se o mesmo processo citado no parágrafo acima. As canecas com água podem ser utilizadas também para se escovar os dentes. 

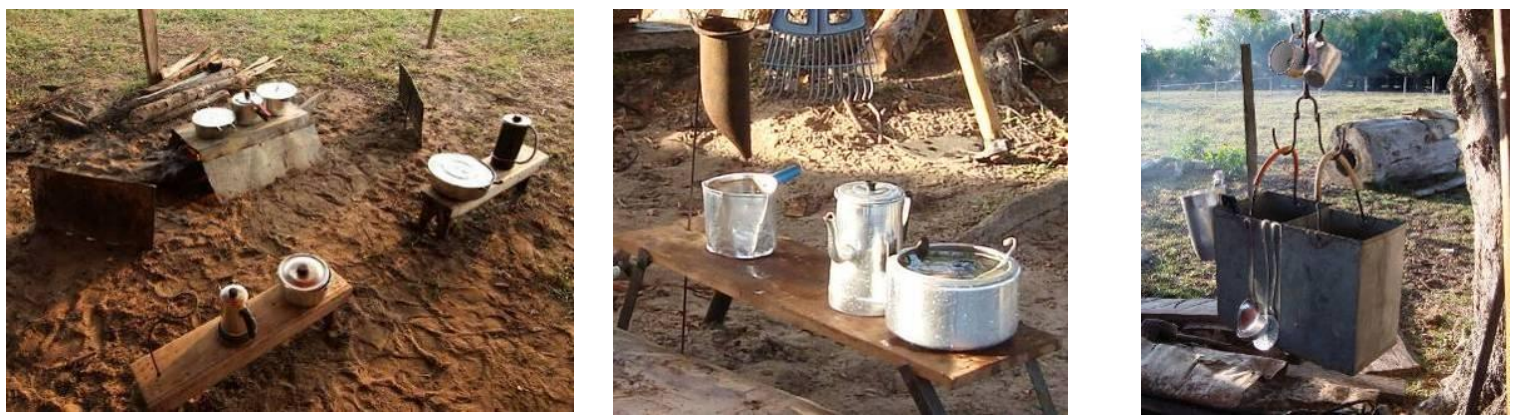

Fig. 52- Organização da cozinha. Fig. 53 - Bule de café e coador. Fig.54- Latas d' água Panelas de comida sobre trempe e o Panela com água fervida, penduradas em figueira fogo. Outros utensílios sobre pequena colher de concha e canecas de (Fícus sp), colheres de concha, mesa de madeira. café. caneca maior para pegar água, menores para bebê-la .

Alguns Cozinheiros comentaram que quando vão apagar o fogo feito para cozer os alimentos, não se deve, presta apagá-lo com água, pois provoca dor nas costas. O entrevistado Biguá apesar de conhecer a regra, colocou que não costuma cumprir a tradição, mesmo porque no período da seca pode ser perigoso que o fogo se espalhe pelo campo. Ele também falou que apesar de não acreditar neste tipo de regra, quem trabalha em Comitiva costuma ser supersticioso.

Observou-se que durante o almoço não se conversa muito e segundo fontes orais, isso pode depender do sistema do Cozinheiro, o qual costuma ser respeitado. Este silêncio pode ocorrer também porque estão no meio do trabalho, preocupados com o gado encerrado ou quando precisam fazer a ronda/arroio.

Arroiá, ocê fica raiando, você fica dando de roda nela, gritando com ela, raiando e surrando com o arreador, táh, táh, táh! Vai surrando com o arreadô, aí ela por si, ela vai ficando, ela vai se embolando e vai deitando, ta cansada e tal, aí as veiz ela toma água, ela já sobe pra toma água e sobe, e fica parada ali em pé, aí você começa a ralhar com ela, e surrá com o surrador, ela deita, fica um bola, fica tudo deitado, aí as vez, vamo dizê, numas 500 rêis, as veiz 10, 15,20 fica de pé no meio ali, de pé bem no meio dormindo, as outra fica tudo deitada. Então, mas você tem que tê cuidado, tem que ficá cuidando, então fica lá conversando, um com o outro, olhando o gado e conversando, isso dai é arroiá. (JUAREZ, 2009).

Durante a participação da primeira e terceira Comitiva ocorreu de não ter lugar para encerrar o gado durante a parada para o almoço e assim, eles se revezaram no cuidado com a boiada, enquanto alguns almoçam, outros ficam cercando a reses, e depois trocam os postos. 
Os que saem para almoçar desencilham seu burro para que este descanse, almoçam rapidamente, pegam outro burro da tropa e retornam para cuidar do gado. Este cerceamento da boiada chama-se arroio ou ronda e segundo relatos dos boiadeiros, isto pode acontecer ainda, quando estão atrasados para chegar ao ponto de almoço.

Se o ponto de armoço tivé meio longe, aí mais ou meno 11 horas, por aí, ocê ta chegando no ponto de armoço, aí você pára o gado, arroia o gado, assim, e o gado chega e já pára e já deita tudo. Aí ocê pode sai, os 3, 4 e armoçá, fica só um, dois cuidando ali o gado, só. Vai lá, armoça, sorta o cavalo, e vorta aqueles que foi armoçá e o que ficou cuidando vai armoça. Aí vorta. Aí quando é mais ou menos meio dia, uma hora, o gado já sabe que já é hora de sai pra andá, né. Aí já vão levantando e vão levantando, forçando, vai saindo já, né. Aí vai de novo. (BARRIGA, 2009).

Dependendo do tipo de rês que a Comitiva conduz, o trabalho pode ser mais difícil. Para

Barriga (op. cit.), o macho é mais difícil de conduzir do que a fêmea, a não ser que esta esteja com bezzero novo.

Não, o mais difícil de, de conduzir é o garrote, o garrote assim, é, 2 ano, 3 ano assim, o macho, tudo o macho é mais difícil, eles começa um subi no outro assim, e começa, junta aquele bando assim, e vai subindo, vai até derrubá dele. Aquele que vai correndo, começa a cansá e começa a cai, dá mais trabalho. E o gado fêmea não, o gado fêmea é acomodado pra viajá, tanto faz vaca ou novilha, é mais fácil docê conduzí, num tem essa putaria de fica subindo no outro assim, obedece mais também.(...) A vaca parida, aí já é mais difícil com bezerro também, num guenta muito a viagem. É novinho, sempre tê um, se for mudá o gado duma fazenda pro outro 2, 3 dia, ou uma semana, se tem bastante vaca parida ou bezerro novo, sempre tem que ir um trator, assim, acompanhando. Aí cedo você pega o bezerro põe num trator, assim, numa carreta, faiz um tipo, uma gaiola, numa carreta, aí os maior já vai. Aí chega no ponto de armoço, aí o trator, o tratorista, chega umas bezerra ali, você desce as bezerra pra mamá, os bezerro mama, aí a hora que você vai sai assim, você vai andando e os bezerro já vai ficando pra traiz, aí cês vão pegando os bezerro, pondo na carreta e vai só no pouso, vai mamá de novo, deixa pousá com as mãe no mangueiro. (BARRIGA, op. cit.).

Já o entrevistado Biguá (2009) acredita que o garrote ou em geral, o gado novo é um tipo de rês que madrinha, acompanha a Comitiva de forma mais fácil:

"O garrote é uma das rêis, bem dizê, mais fácil, o garrote e a novilha é mais fácil né, ele madrinha [acompanha] mais rápido, né. É gado novo, né (...) gado mais difícil de mexer com ele é o touro véio e vaca, vaca véia boiadera. Vaca boiadeira num madrinha, ela é igual a égua. Amanhece o dia cantando, já né. É o dia inteiro ocê surrando ela e ela não pega passo. Uma boiada de 1.000 vaca aí, você trabalha o dia inteiro, é o dia inteiro na larga assim, (...). É a mesma coisa que tocá um rebanho de égua, hmm..., a bicha é desmiolada. Agora o boi, o boi castrado, o garrote e a novilha é um 
gado bom de mexê, que é madrinhado né.. Um gado que ocê com três, quatro dias ele madrinha com a tropa, você tocou o berrante, ele levanta a cabeça e vai embora".

De qualquer forma, é necessária muita paciência na condução do gado. Esta é uma característica percebida como marcante na personalidade dos boiadeiros e parece ser exercitada no cotidiano que o boiadeiro vivencia, pois há necessidade em se conduzir o gado vagarosamente, para que este chegue saudável ao seu destino. O gado e a tropa devem pastar devem pastar constantemente, mas há um cuidado permanente, um equilíbrio em alimentar-se e mover-se constantemente na direção orientada pelo boiadeiro. Contudo, para dessedentação dos animais há como regra que quando quaisquer uns destes decidam parar para beber água, os boiadeiros devem aguardar pacientemente, nunca os interrompendo.

Ocê vai devagar, dando pasto pro gado, vai devagarzinho até chegar no ponto de armoço. Aí o Cozinheiro vai tá lá já, esperando cum o armoço pronto. Aí você armoça e troca de animal também de novo, sorta aquele que tá de manhã, pega outro a tarde proce chegar até na outra fazenda, mais devagar, né. Ocê anda mais ou menos umas quatro léguas assim, durante o dia. (BARRIGA, 2009).

Em relação ao cumprimento das regras e rituais descritas neste capítulo, observou-se que há grande respeito pelas mesmas. Entre os boiadeiros não parece ser algo discutido ou questionado, são aceitas como parte do cotidiano. Pode ocorrer de algum deles não cumpri-la, mas então ele também não será respeitado e será apontado pelos outros como um profissional ruim, desqualificado. No que foi possível, este modo de vida, de ser boiadeiro não contribui apenas na utilidade da organização da Comitiva, mas está imbuído de valores humanos e de uma conduta ética que legitima esta cultura.

Quando se trata das viagens pelas estradas, nota-se que seus princípios de ser, existir e conduzir boiadas estão conectados ao movimento que estas sugerem, revelando símbolos e imagens de uma vida ativa, paisagens e acontecimentos de origem variada, mas que segue um ritmo na maior parte do tempo vagaroso, marcado pela paciência e sensibilidade para orientar reses e muares. 
Já no que se refere aos pontos de parada na viagem, percebe-se significados relacionados ao conceito de lugar e talvez possamos compará-los ao espaço de intimidade, que remete a casa, refúgio, abrigo, (BACHELARD, 19?-, p. 18-19). É o que expressa Biguá (2009), quando fala sobre as lonas utilizadas no ponto de pouso: "A torda é a lona, a lona 3 por 4, uma loninha 3 por 4. Cada um peão tem uma, né uma loninha 3x4, ali é a casa dele, né. Chegou de tarde já arma ela”.

Apesar de haver certo paradoxo nesta colocação, pois os boiadeiros são itinerantes e compartilham espaços com colegas de trabalho, muitas vezes estranhos uns aos outros, a cozinha na Comitiva, com seus elementos organizados e suas regras representam durante as viagens, o universo da morada, nas paradas de almoço e pouso. É o lugar representado por pontos fixos de referência96, onde se alimentam, descansam, dormem e onde estão todos reunidos.

Este modo de viver organiza o espaço onde convivem no dia a dia. (TUAN, 1983). São práticas cotidianas vividas que mostram peculiaridades, parcialidades da imaginação, sentimentos, sensações que vão desde o modo como reconhecem uma rês doente ou parida pelo seu cheiro, até como servem o almoço ou como realizam, pacientemente, a condução do gado.

\footnotetext{
${ }^{96}$ Sobre pontos fixos de referência ver ítem 3.1, p. 124.
} 


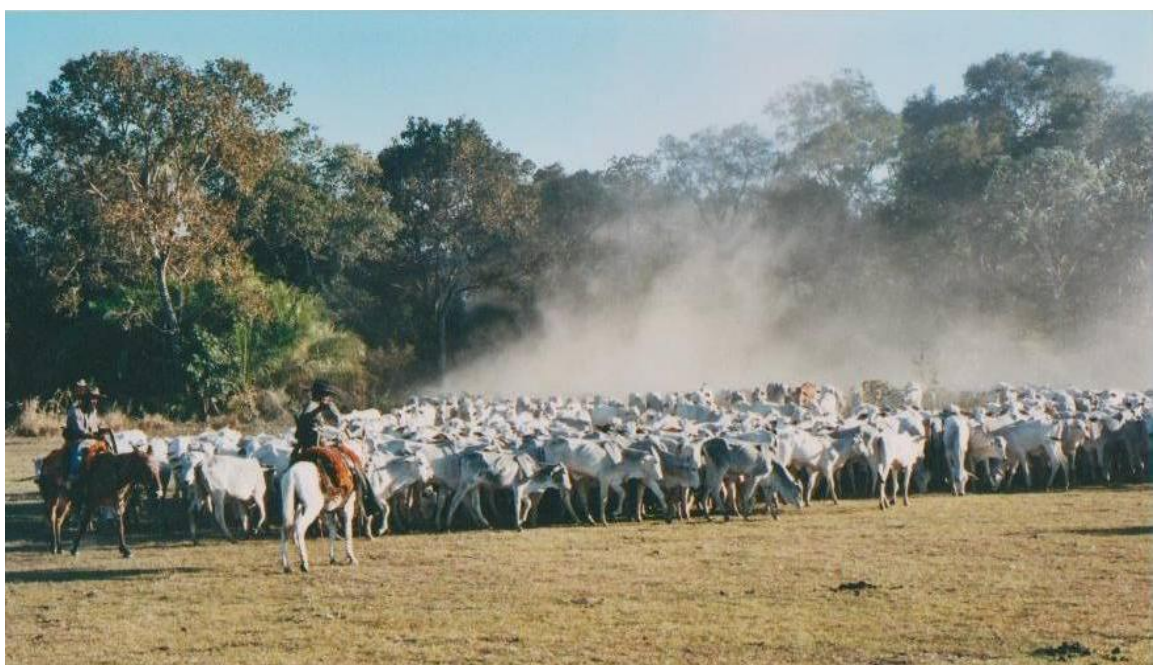

Fig. 55 - Poeira no estradão: terceira Comitiva.
O prazer do boiadeiro é sentir aquele cheiro de poeira por detrás da boiada, aquilo vai indo, conversando cum a boiada, tudo alegra, cantando, outros vai, vai cantando, contando causo, sabe? (...). E a pessoa conhece muito lugar, sabe?

Viajando assim, porque ele vai viajando (...). Ele vai fazer um pouso numa fazenda, um dia é um que toca a tropa, tem dia é outro (...). Rondon (1996 apud FERNANDES, 2002:58).

Dessa forma acredita-se que é possível conhecer um pouco de como o ser boiadeiro se apropria do mundo e das paisagens pantaneiras. 


\section{CAPÍTULO 3 - COMITIVA PANTANEIRA: LEITURAS DAS}

\section{PAISAGENS}

Nos campos infindáveis, aprazia-lhe cortar rumo, com a segurança instintiva de guia certeiro, a cujo olhar arguto se desdobrasse todo o terreno como em carta fielmente representativa das minúcias topográficas. Ainda quando não tivesse jamais palmilhado a região, desde que semelhante à sua querência, a vegetação de colorido mais ou menos intenso, o vôo e canto das aves, a presença de certas caças e tantos outros indícios quase imperceptíveis às vistas comuns, bastariam para lhe balizar a marcha, através de obstáculos naturais nas melhores passagens possiveis, evitados os maiores atoleiros ou travessias perigosas. No seguir a batida de algum lote desgarrado, ou rastrear animal fugido, mais eficientemente não atuaria agudo faro canino (CORRÊA FILHO, 1946, p.123).

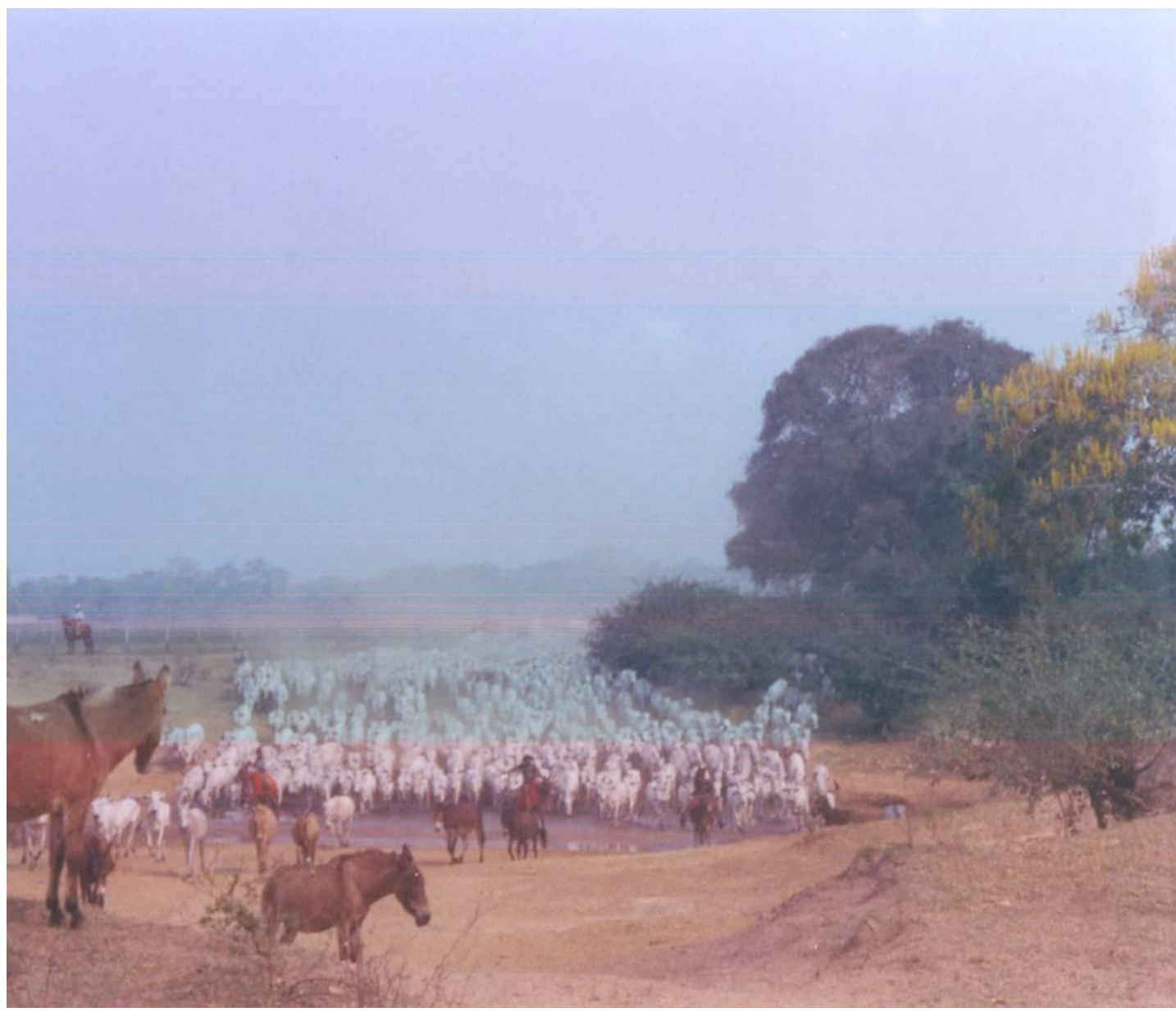

Fig. 56 - Estouro de boiada na travessia do Rio Abobral. Comitiva da Nossa Senhora de Fátima. 
Este capítulo trata da interpretação do modo como os boiadeiros lêem as paisagens pantaneiras, a partir da idéia de lugar baseada em uma interpretação da espacialização. As leituras estão relacionadas à experiência de vida dos boiadeiros e aos roteiros de viagem das Comitivas no Pantanal, constituídas por diversas formas de linguagem que podem se expressar por meio do reconhecimento de marcos referenciais nas paisagens. Estes, por sua vez, podem representar situações vividas, objetos e configurações. É o que Tuan (1983) consideraria como um mundo elaborado a partir de leituras intersubjetivas, impressões e vivências cotidianas.

Neste contexto, a partir do levantamento de dados empíricos, foram identificadas diversas formas de orientação utilizadas pelos boiadeiros sobre as quais se realizou um recorte durante a análise categorial dos discursos coletados (BARDIN, 1995), organizando-as em duas temáticas principais. São elas:

3.1 Na batida do estradão - marcos referencias na paisagem: este tema trata dos significados atribuídos aos lugares sob os quais os boiadeiros se orientam durante as Comitivas.

3.2 No ritmo das águas do Pantanal: o foco deste recorte consiste nos significados atribuídos a dinâmica hídrica do complexo Pantanal, os quais se relacionam às escolhas dos trajetos de viagem dos boiadeiros.

Vale salientar que estes dois temas, por estarem intimamente integrados, possuem elementos que, sem prejuízo, são encontrados nas análises de um e de outro. 


\subsection{Na batida do Estradão - marcos referenciais na paisagem}

A partir da vivência do boiadeiro e de sua rede de relações dinâmicas com as paisagens são construídas e reconstruídas formas de leitura primordiais para a orientação espacial durante a condução o gado. Esta capacidade se dá, principalmente, pela da interpretação de um sistema simbólico de referências nas paisagens e de formas de comunicação entre moradores das fazendas e boiadeiros, ou seja, por meio dos marcos referenciais da paisagem.

Apesar de não existir na literatura mapas dos roteiros das Comitivas de viagem, os boiadeiros se utilizam de roteiros definidos, marcados pelos pontos de parada para almoço e pouso em determinadas fazendas. Estes roteiros fazem parte, principalmente, do conhecimento dos Cozinheiros, Condutores e Ponteiros, adquirido pela experiência vivida no ambiente da fazenda.

É que nem um mapa mesmo, né. Tem hora que pensa que ta vortando pra trás e lá na frente alinha de novo e vai no rumo assim. Agora Fazenda Santa Rosa. Você põe um tracinho no meio. Tracinho no meio, que é o ponto de armoço no meio. (BIGUÁ, 2009).

Tem, tem Ponteiro, que ele é tão viajado, tão conhecido, que é tão conhecido, ? que ele só olha e fala, vamo entra aqui, vamo entrá bem aqui, ir reto aqui, ó. Ce já sabe que essa estrada sai aqui, mas primeiro ela vai dá volta, vai sair lá. Então a gente já corta um atalho aqui, entendeu. A gente corta um atalho aqui, então assim que é a lida...(JUAREZ, 2007)

Há inúmeros caminhos que passam por estradas de asfalto, cascalho, estradas boiadeiras ${ }^{97}$ e cada Comitiva tem seu trajeto traçado previamente. Pode-se então, interpretar

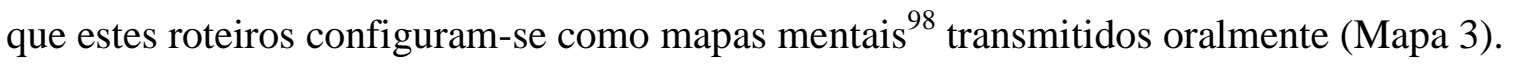

A gente tem um roteiro traçado. Quando a gente vem, quando a gente vai vir, o Cozinheiro já sabe. Por exemplo, [faz desenho com graveto na areia] ${ }^{99}$ nóis tamo aqui na São Sebastião, daí a gente tem que vim aqui, vamo fazê, vamos supor, na Novo Horizonte, onde a gente tem que pousar, dá doze

\footnotetext{
${ }^{97}$ As estradas boiadeiras são as estradas, normalmente, utilizadas pelos boiadeiros durante as viagens em Comitivas. Ver tabela 5, p. 127.

${ }^{98}$ Sobre mapa mental, ver 1.3 , p. 67.

${ }^{99}$ Durante a primeira entrevista com Juarez, em 2007, ao mesmo tempo em que ele falava sobre os roteiros das Comitivas, fazia desenhos na areia de simbras, porteiras de vara e outros referenciais de orientação. Infelizmente não foi tirada nenhuma foto destes desenhos, mas durante a segunda entrevista com o mesmo, em 2009, foi feito o mapa de um dos roteiros da Comitiva, narrado pelo entrevistado e desenhado pela pesquisadora (Apêndice C. Mapa Juarez)
} 
quilômetros. Normalmente, na média de cinco a seis quilômetros, na metade da caminhada, o Cozinheiro, tem uma água boa por ali (...). (JUAREZ, 2007).

Estes doze quilômetros ou duas léguas (medida mais utilizada pelos boiadeiros) significam a média diária da distância percorrida e é representado por uma marcha. Como coloca Barriga (2009), "você anda mais ou menos umas quatro léguas assim (...) por aqui, pra saí pra Senhora do Carmo mais perto tem que dá tudo essa vorta, aí eles vão gastar mais ou menos cinco marchas, seis marchas".

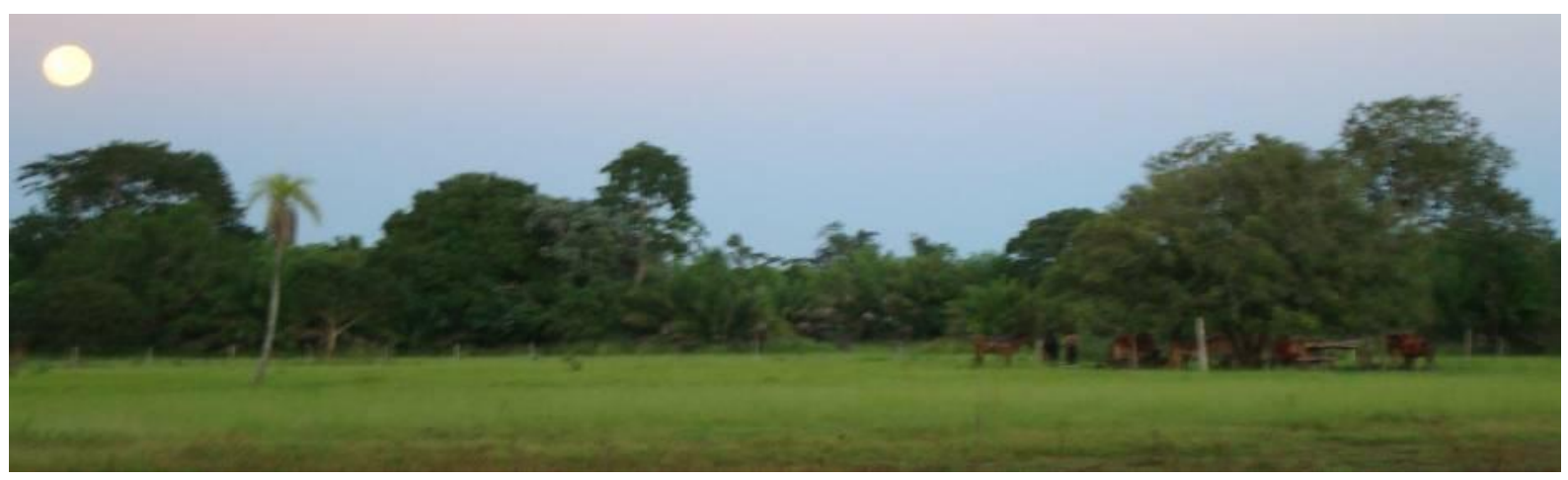

Fig. 57 Amanhecer no ponto de pouso da fazenda Nossa Senhora do Carmo. Comitiva desconhecida.

Por meio da combinação prévia, geralmente, entre o Cozinheiro e o Condutor, são combinados os locais de encontro dos pontos de parada.

O Cozinheiro já conversa com o Condutor, que é o capataz da Comitiva, né. Ele fala, vamo pousar lá em tal lugar. Nóis vamo por aqui. Tem vários lugares pra você ir, então nóis vamo por aqui, nóis vamo fazer essa rota. Nóis vamo pousá lá na São Sebastião. (...).

Que nem um caso, você tava perguntando, como é que a pessoa sabe? É, tem muitos Cozinheiro que se perde, depois tem uma estradinha muito apagada (...) e o Condutor confia nele, de explicar pra ele, olha eu vou te explicar como é que você vai lá no pouso. Eu vou te explicar pra você saber como é que vai sair lá no pouso, então ta, então tá bom. Ó, você entra aqui, pega, bem aqui assim, tem um canto de cerca, você vai entra aqui, aqui tem um canto de cerca, naquele canto de cerca você pega pra direita, aí você anda tipo uns mil metros, que você vai enxergar uma campina aqui. (...) aí você entra no costado daquela campina assim, ó, ocê vai pegá uma estradinha apagadinha, e você segue nela. Como muitas veiz acontece deles faze e tentá fazê isso, em veiz dele pegá o lado certo ele pega o lado errado, aí ele perde, aí ele perdendo a hora de almoço, já foi, o almoço seu já era, aí é só a janta. (JUAREZ, 2007).

Nos relatos orais é possível observar que a principal referência utilizada pelos boiadeiros para se orientarem são os nomes das fazendas de gado. Nogueira (2002, p. 39) também atesta 


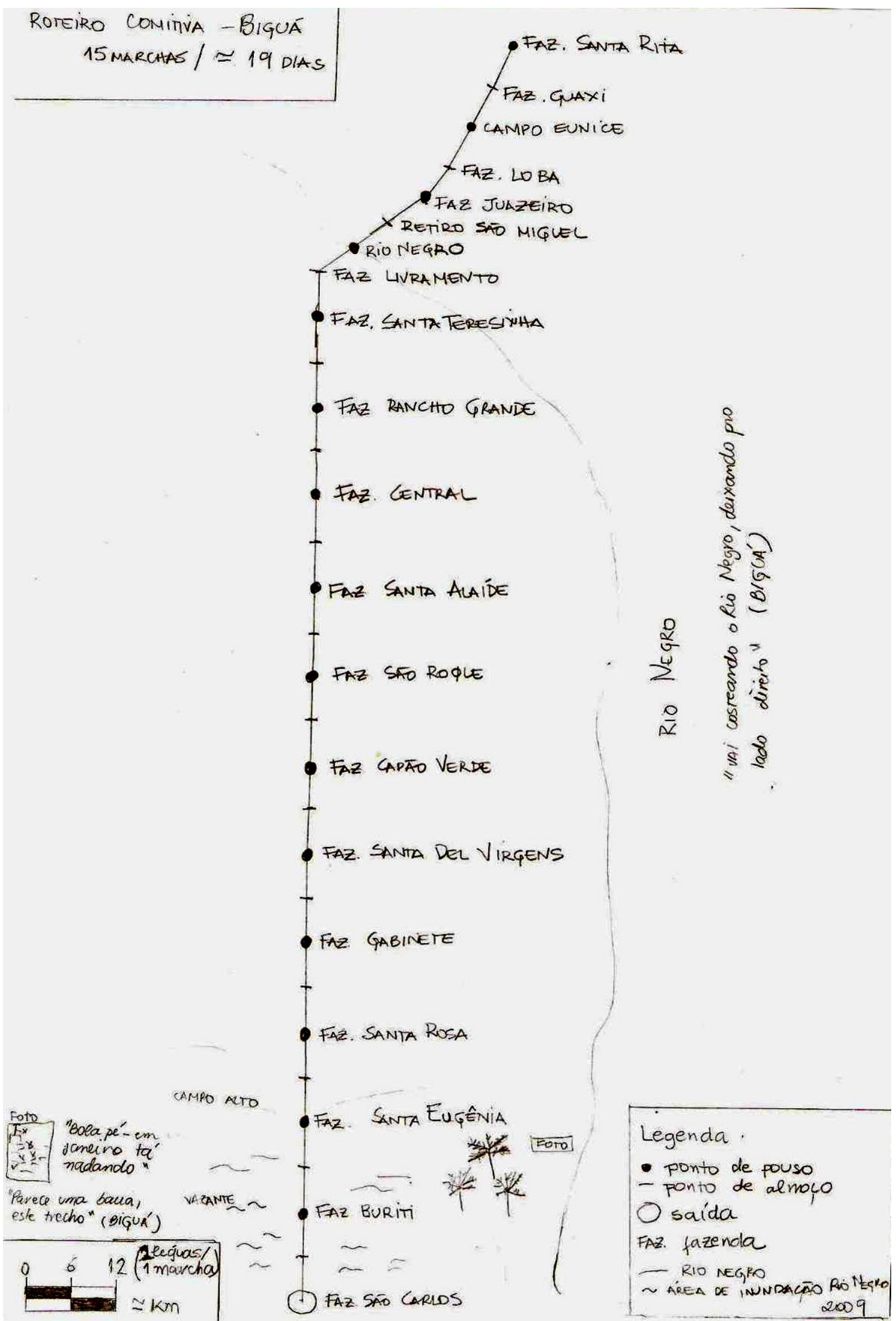

Mapa 3 - Mapa falado por Biguá (2009) do roteiro de Comitiva de Aquidauana a Fazenda Central. 
a importância destas fazendas, assim como o entrevistado Juarez (2009): “Aí do Livramento nóis vai na Juazeiro, do Juazeiro nóis vai na São José, da São José nóis vai na São Sebastiãozinho, da Sebastiãozinho nóis vai na Novo Horizonte”.

Um exemplo: Nós vamos sair daqui, nós vamos lá no São Domingos, com a Comitiva. Aí a Comitiva, o Cozinheiro fala assim, nós vamos almoçar lá no Retiro Novo, né, nós vamo almoçar lá no Retiro Novo, daí, o Cozinheiro vai chegar lá no Retiro Novo vai desencilhar os burro, dali perto da onde tem uma água. (Ibid, 2009).

Não obstante, os marcos referenciais na paisagem costumem advir das diversas formas de registros que foram sendo "impressos" na paisagem e são decorrentes da atividade pecuária, as informações sobre disponibilidade de água para dessedentação, preparo de refeições e banho também são de suma importância. Esta disponibilidade é uma condição que influencia diretamente na opção pela Comitiva, na escolha dos pontos de parada e pode até mesmo, definir o roteiro de transporte da boiada. ${ }^{100}$

Há ainda outros elementos que constituem as paisagens no Pantanal, que representam referências para a orientação dos boiadeiros. Alguns destes, relacionados diretamente com o as paisagens da fazenda foram agrupados na tabela abaixo.

Tabela 5 - Marcos referenciais da paisagem: paisagens da fazenda

\begin{tabular}{|l|l|l|}
\hline \multicolumn{2}{|l|}{ MARCO REFERENCIAL } & REFERÊNCIA/ DESCRIÇÃO \\
\hline Cerca & & $\begin{array}{l}\text { (...) entra aqui, pega, bem aqui assim, tem } \\
\text { um canto de cerca, você vai entra aqui, aqui } \\
\text { tem um canto de cerca, naquele canto de } \\
\text { cerca você pega pra direita (...) (JUAREZ, } \\
2009) . \\
\text { Também costumam dizer: Vai beradiando a } \\
\text { cerca ou divisa de cerca com outra fazenda. }\end{array}$ \\
\hline
\end{tabular}

${ }^{100}$ Ver mais no próximo item, pg. 143. 


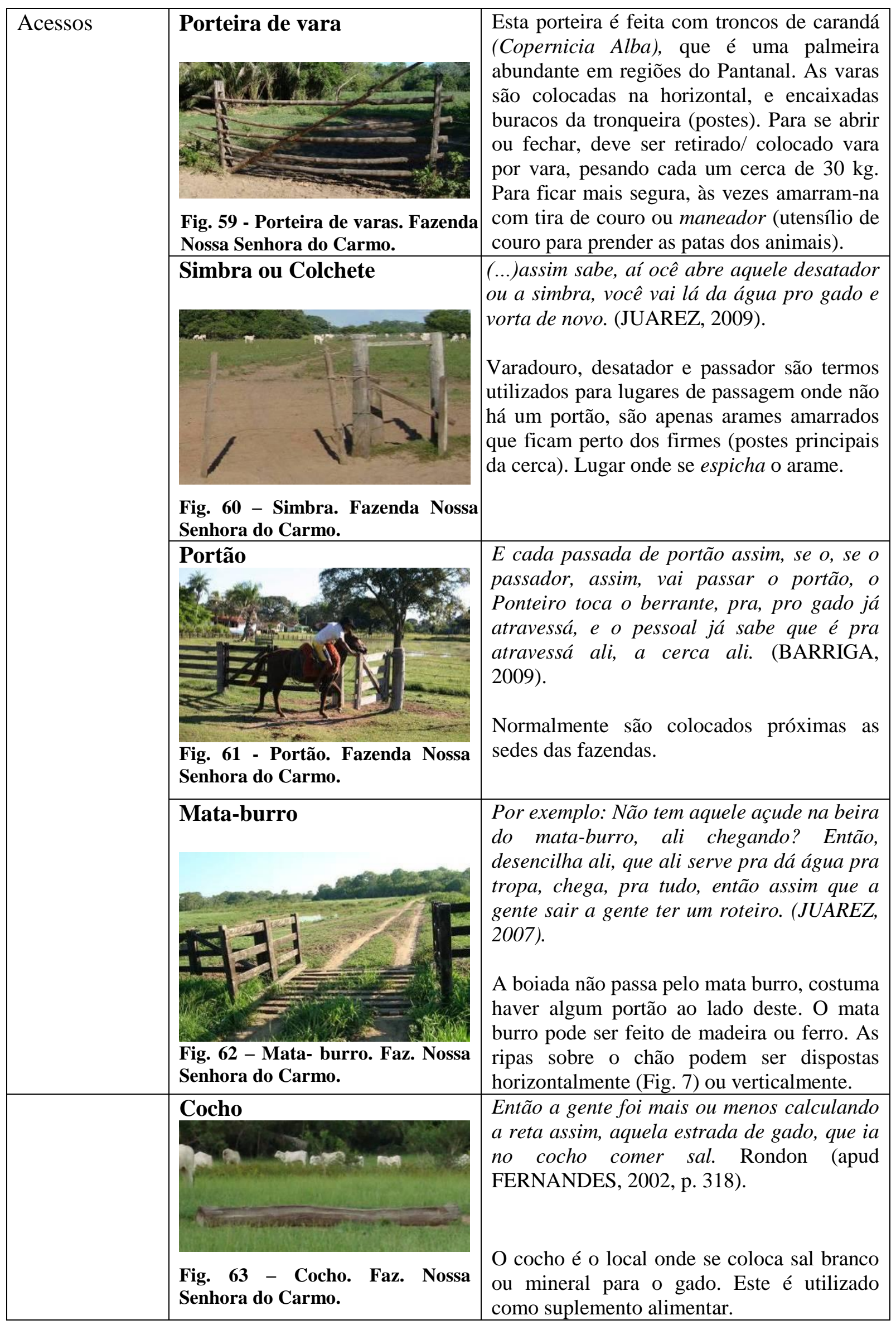




\begin{tabular}{|c|c|c|}
\hline Ponte & $\begin{array}{l}\text { Fig. 64 - Ponte sobre o Rio } \\
\text { Abobral. Segunda Comitiva. } \\
\text { Pousada Xaraés. }\end{array}$ & $\begin{array}{l}\text { As pontes costumam ser feitas de madeira. } \\
\text { Pode-se utilizar aroeira (Myracrodruon } \\
\text { urundeuva), angico vermelho (Anadenthera } \\
\text { colubrina), Gonçalo (Astronium } \\
\text { fraxinifolium), entre outras. } \\
\text { Segundo relatos, os pecuaristas não gostam } \\
\text { que passem com boiada alheia em suas } \\
\text { pontes, por prejudicarem o estado de } \\
\text { conservação destas. } \\
\text { As pontes facilitam o transporte de gado, por } \\
\text { outro lado, o gado tem que aprender a passá- } \\
\text { la, exigindo uma habilidade diferente dos } \\
\text { boiadeiros na condução do gado. }\end{array}$ \\
\hline \multirow[t]{2}{*}{$\begin{array}{l}\text { Acessos a } \\
\text { água }\end{array}$} & $\begin{array}{l}\text { Açude } \\
\begin{array}{l}\text { Fig. } 65 \text { - Comitiva Caiman. Fonte: } \\
\text { Thiago Rocha. }\end{array}\end{array}$ & $\begin{array}{l}\text { É o único açude que tem pra ele dar água } \\
\text { pro gado. Só que o que ele faz? Ele faz esse } \\
\text { caminho, vai lá no açude, pro gado tomar } \\
\text { água, aí de lá ele vai sair aqui, ele vai cair } \\
\text { na estrada lá na frente. Nunca ele anda na } \\
\text { estrada, porque ele tem que dá, ele tem que } \\
\text { ir dando pasto pro gado. (JUAREZ, 2007). } \\
\text { Os açudes são feitos principalmente, como } \\
\text { reservatórios de água para dessedentação dos } \\
\text { animais de criação durante a época da seca. } \\
\text { Normalmente, na média de } 5 \text { a } 6 \text { km, na } \\
\text { metade da caminhada, o Cozinheiro, tem } \\
\text { uma água boa por ali, uma água boa que a } \\
\text { gente chama é um açude. Quando você acha } \\
\text { um açude de água branca, de água limpa, } \\
\text { nossa! É muito bom! (JUAREZ, 2009). }\end{array}$ \\
\hline & $\begin{array}{l}\text { Fig. 66. Poço na invernada Antena. } \\
\text { Faz. Nossa Senhora do Carmo. } \\
\text { Terceira Comitiva. }\end{array}$ & $\begin{array}{l}\text { Tem um poço lá que tá bem no, quase no } \\
\text { meio dela assim, aquele poço ninguém sabia } \\
\text { daquele poço. (...) agora que secô ela [baía] } \\
\text { apareceu, aquele poço lá no meio dela. Esse } \\
\text { povo que é dono daí, muitos ano que eles são } \\
\text { dono dela, diz que nunca viu, esse poço lá. } \\
\text { (BIGUÁ, 2009). } \\
\text { Os poços são construídos, especialmente, em } \\
\text { sedes e retiros de fazenda, mas dependendo } \\
\text { da disponibilidade de água podem estar em } \\
\text { invernadas. Suas profundidades variam de } 4 \\
\text { a } 30 \text { metros, podendo ser de material de PVC } \\
\text { (atualmente) ou cimento. } \\
\text { Na terceira Comitiva, observou-se que um } \\
\text { poço representava o marco referencial para o } \\
\text { ponto de almoço (ilustração ao lado), porém } \\
\text { a água estava suja, e então se pegou água em } \\
\text { uma vazante próxima. Antena. }\end{array}$ \\
\hline
\end{tabular}




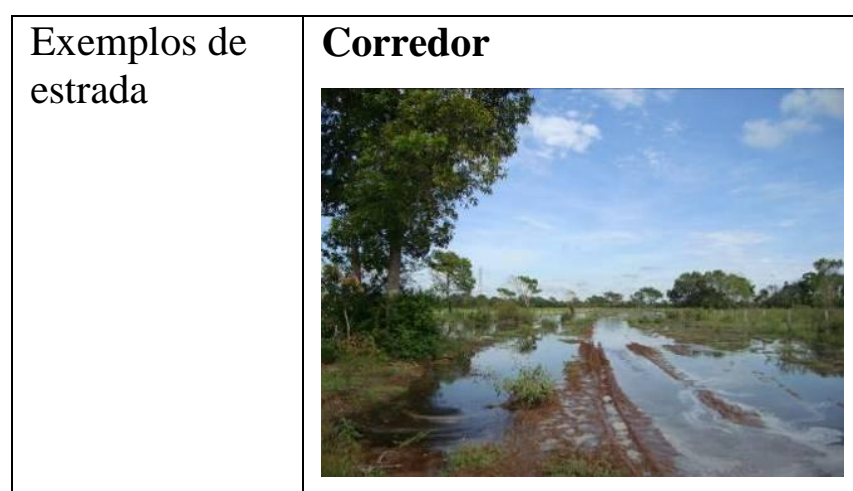

Fig. 67 - Corredor Faz. São Bento. Região Abobral.

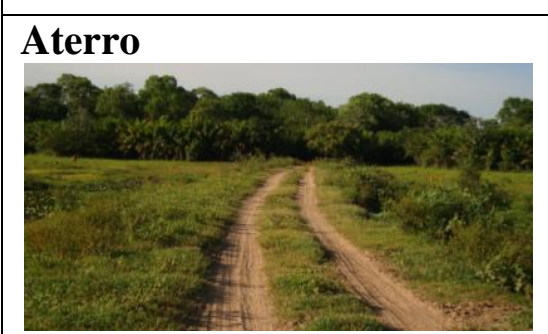

Fig. 68 - Aterro. Faz. Nossa Senhora do Carmo.

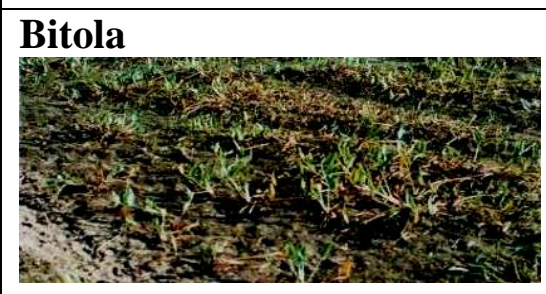

Estrada boiadeira, boiadeira central, boiadeira mestra

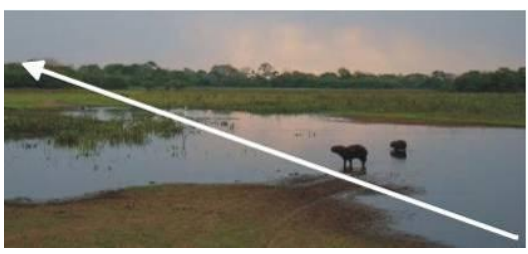

Fig. 69 - Boiadeira Central. Faz. São Carlos (seta branca indica estrada).
Cê, tipo, ocê vem lá do retirinho, são $70 \mathrm{~km}$ pra você chega em Aquidauana, você não tem trabalho nenhum, você só solta o gado do mangueiro ${ }^{101}$, e cê já sai com o gado pro mangueiro, você sai dentro do corredor, dos mangueiro já tem entrada já pro corredor, entrada e saída pro corredor. (JUAREZ, 2007).

Corredores são áreas cercadas, que facilitam o transporte do gado. Os boiadeiros também chamam estes corredores de leva cansado, pois dizem que os que trabalham nas laterais, principalmente, os Meeiros, podem descansar nestes momentos.

Eles vão dá a vorta, pra saí no aterro, pra pegá o aterro pra vim pra cá, pra saí no Buraco das Piranhas (BARRIGA, 2009).

Ela sai do Rio Negro, que a ponta do aterro que vem do Rio Negro, ela vem até um trecho no Pantanal, aí caba o aterro.(BIGUÁ, 2009).

(...) é tem uma bitola ali, (...) num tem essa estradinha aí, olha, uma bitolinha?

(JUAREZ, 2007).

É um caminho por meio do campo, marcado pelas rodas do carro e que por ser pouco utilizado, pode ser de difícil identificação.

Num tem as estrada, essas estrada, né, é estrada boiadera. Tem muitas estrada, né, mas aquela ali é a boiadera, né. (...).

É a boiadeira central, que fala, né, é aquela que é a rumo reto, né. Ela sai do Porto Santa Luzia e vem bater em Aquidauana, meio rumo reto, assim.

(...) Aqui vem do Corixão, aí tem a estrada mestra que desce aí, ele vem saí na curva do leque. Tem umas estradas boiadeira que sempre cruza ela pra lá, cruza ela pra cá. Aqui tem o Porto de Santa Luzia que vem do Paiaguás, aí tem uma boiadeira mestra que sai na Barra Mansa, aí tem uma boiadera mestra que tora no meio. (BIGUÁ, 2009).

Há várias estradas boiadeiras, a via central chama-se boiadeira central, ou mestra. (Apêndice B - Mapa Entrevista II).

\footnotetext{
${ }^{101}$ Local onde é feita a aplicação de vacinas, medicamentos para doenças do gado, aparte do gado, entre outros.
} 


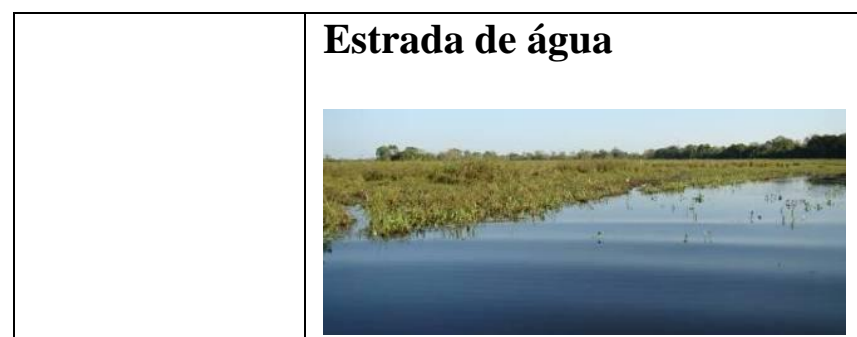

Fig. 70 - Estrada d'água. Faz. Nossa Senhora do Carmo.

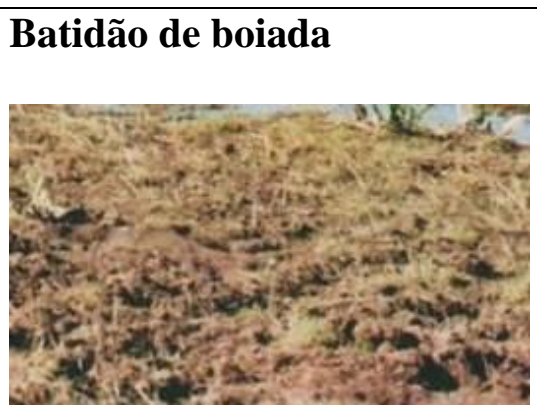

Fig. 71. Batida de Boiada. Região Abobral

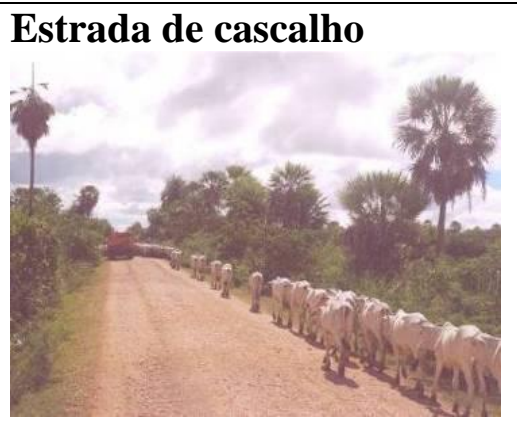

Fig. 72 - Estrada de cascalho. Região Nabileque.

Quando tem água é difícil, cê vê só o ripão [marca] da estrada assim, tem vez que vê, tem veiz que não vê. Quando a água tá limpa cê vê, estrada de trator, de carro, quando a água tá meia suja ocê não enxerga, fica difícil ver. Tem que ser só pelo batidão da boiada memo (risos).(BIGUÁ, 2009).

Devido à passagem da boiada de Comitivas e de carros, estas estradas ficam marcadas. E, por vezes, pode se observar também que a lâmina de água quase não possui vegetação.

É que nem tá aqui, essa estrada aqui é uma estrada muito batida de boi, eu ia falá pra senhora pegá o batidão da boiada. Pegá o batidão de boi, porque pelo batidão de boi aí, aí não tem como errá, né. Agora tem lugar que não passa quase boi e fica mais difícil, né, porque as veiz a estrada já é apagada e num tem batidão de boi. Lugar que passa boi, boi direto é trião assim, esse triero tudo é contínuo né, é diferente de triero de invernada, né, porque triero de invernada é tudo cruzada assim, né. (BIGUÁ, 2009).

Como várias Comitivas passam pela mesma estrada, a observação do sentido do pisoteio da boiada é muito utilizada para orientação. Estas batidas também ficam mais fundas em locais mais estreitos, como por exemplo em passagem de portão, beira de cerca, etc.

Normalmente, é estrada de cascalho, você só anda nela em último caso, quando não tem corredor, que nem a estrada que você vai pra Porto Murtinho, (...) só anda no cascalho em último caso, porque senão a boiada, a tropa num guentá, tropeia. Quando num tem jeito que é só cascalho, aí você vem tem que ir bem devagarzinho, mas normalmente é pedacinho curto. (JUAREZ, 2007).

Durante as saídas a campo, uma característica marcante foi observar cerca de mil cabeças de gado atravessando áreas de vegetação que vão desde campo-cerrado e matas fechadas de cerradão, a estradas de cascalho e asfalto. Apesar da dificuldade em áreas de mata densa, as estradas de rodagem também podem atrapalhar ainda mais o curso das Comitivas e provocar maior esforço dos animais, que não estão adaptados a marchar no cascalho ou 
asfalto. Estas estradas permitem a circulação de veículos, mas por outro lado causam impactos imensuráveis na paisagem pantaneira, incluindo alteração da dinâmica de drenagem das águas e de circulação da fauna silvestre.

É, e o asfalto também, né, você anda no asfalto em último caso, você pode ver, as veiz quando encontra gado no asfalto, na BR, mas é arguma rêis, as veiz, e quando não dá pra ele andar na lateral do asfalto, que eles num andam.(...) Só quando tem que andar no asfalto, tem que usá [sinalização], mas pode ver que sempre tem, na frente da boiada, há uns 500 metros, tem uma pessoa com uma bandeirinha vermelha, que significa que tem gado na estrada, então, pra turma vê e diminui, porque pode atropelar uma rêis, acontecê um acidente, basicamente é isso. (JUAREZ, 2007).

Nas viagens por estradas de asfalto, um dos boiadeiros deve ir à frente, levando uma

bandeira vermelha para avisar da aproximação da boiada. Mais dois ou três peões seguem atrás, vigiando o gado para evitar que se perca alguma rês.

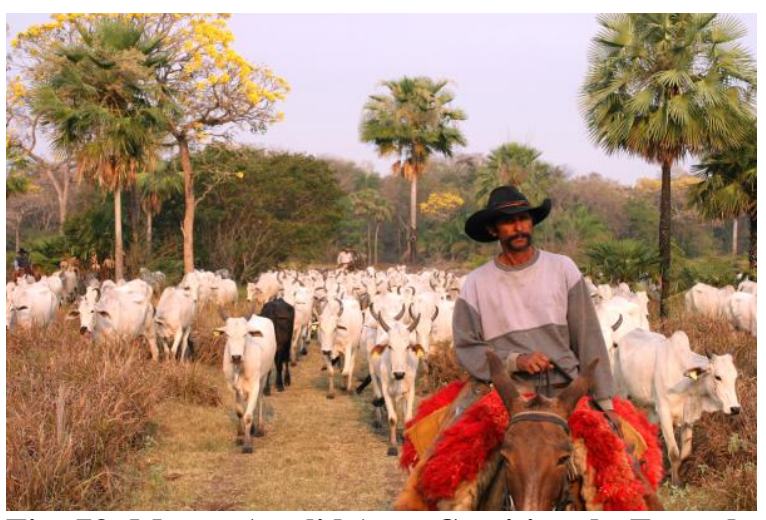

Fig. 73. Magro (apelido) na Comitiva da Fazenda Caiman. Fonte: Thiago Rocha.

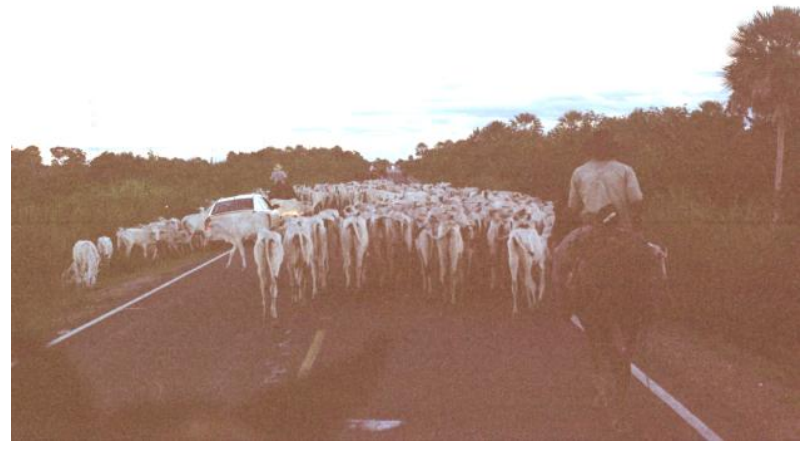

Fig. 74 - Asfalto. BR164. Região Nabileque.

Sobre os "corredores" citados na tabela acima, observou-se que muitos fazendeiros os estão construindo nas estradas boiadeiras, alterando algumas tradições das Comitivas.

Então, era bem cansativo, nossa, agora não, agora ta fácil. (...). Então ocê não tem trabalho nenhum, cê tem que ta ali, o trabalho é que você tem que tá ali, né. (...). Hoje, quase todo lugar por aí tem corredor, então o trabalho que ocê tem é de enfiar o gado lá dentro e ir prestando atenção nas cercas, se não tem nenhuma arrebentada, costada (...) e ir beiradiando e sair. Só isso. (JUAREZ, 2007).

Além do mais, estes podem alterar a disponibilidade de água e pasto e, às vezes, representar uma dificuldade para o boiadeiro perante uma necessidade primária destes viajantes, sobretudo no período da seca. 
Porque no corredor ele vai comer o que vê no corredor, de repente quando você vem vindo com uma boiada assim, passou duas na sua frente, então já comeu o que tinha, então normalmente, muito pouco sobra pra ele comê. Aí chega no ponto dali 20, 30 dias, que ele ta muito fraco, aí ocê tem que arrumá algum lugar pará, e dá pasto, dois, três dia, pra ele se refazê de novo. Você entendeu (...).

É mais difícil, mas normalmente, sempre em algum trecho do corredor assim tem uma, uma parte que tem é bem mais larga no corredor, então sempre eles deixa, eles fazem já o corredor com essa preocupação, de deixá sempre um lugar onde nunca seca, ou que tem um açude que é feito com máquina entendeu, faiz um açude, né, aí faiz aquela parte mais larga assim, que serve pro cara reuni o gado, fechá o gado. Então os fazendeiro, já pensa, já pensam nisso, já faz onde tem a água, a aguada, né, um lugar mais aberto assim, já lá na frente ele já segue e pega o corredor de novo e aí fica numa largura já normal, né. (...), assim sabe, aí ocê abre aquele desatador ou a simbra, você vai lá da água pro gado e vorta de novo. (JUAREZ,2007)

Segundo pecuaristas, uma das razões desses corredores é a introdução de espécies exóticas indesejáveis ${ }^{102}$ nas fazendas pantaneiras, transportadas através do trato digestivo do gado e disseminadas pelas fezes ou regurgito. Há também relatos de problemas relacionados aos lixos deixados por boiadeiros, abuso do pastoreio do gado e, o mais grave, deixarem entrar gado dos mesmos (ou gado alheio) à boiada da Comitiva. O entrevistado Juarez também comenta sobre o assunto.

Tipo esses corredor que sai aqui na fazenda, hoje tem daqui de Aquidauana que sai até muito dentro? Desse Pantanal, tem corredor. Fazendeiro se preocupa muito em fazer corredor não só pra facilitar o trabalho do boiadeiro, não só pra isso, também pra facilitar um pouco o trabalho do boiadeiro, mas mais pra preservar o campo dele. Porque o boiadeiro ele num ta nem aí, se vê um campo bom assim de pasto, bom, ele fica enrolando com o gado, pro gado comer, e as veiz falta pasto pro gado dentro da fazenda. Então, já fez o corredor, então onde que é, já é bem limitado, né, uns 20 metros de largura, aí ele pasta só ali, ele perde pouco pasto. (JUAREZ, 2007)

O fazendeiro não gosta que você anda no campo dele, porque tanto você pode perdê gado, num é o problema de você perdê, o problema é de você,, tem muito nêgo também, que usava de muito ma fé também, né, o gado do fazendeiro enlotava no meio do gado, da boiada e levava embora, cê entendeu, é, vamo supor, de 20 Condutor, uma veiz sempre tinha um que era meio malandro, então levava muito gado de boiadeiro, de fazendeiro, né. Então, o fazendeiro, vamô fazê corredor, né, então passa aqui, então é. Tem veiz também entra e enlota, as vez, sem o cara querer, ocê entendeu? Daí, o que que o boiadeiro faz, num vou parar aqui que é muito trabalho, então eu vou indo, a hora que ele acha um lugar lá pra frente, ele laça a reiz, ele volta, tira pra cerca, né, mas sempre tem as veiz, tem argum que é mau funcionário. (JUAREZ, 2009).

102 Tal como a disseminação da Arumita (Acacia farnesiana). 
Outra tensão entre a relação pecuarista e boiadeiro, apontada por fontes orais é que antigamente as Comitivas tinham livre acesso às fazendas, mas atualmente, proprietários de terra utilizam-se de cercas, acarretando mudanças no modo de viagem das Comitivas. Dizem que esses proprietários não são pantaneiros, são imigrantes vindos geralmente de São Paulo, Rio de Janeiro, Minas Gerais, Rio Grande do Sul, e que não compreendem o sistema da região.

Já não é já, não tem mais aquela liberdade, que tem né. Quando você chegava na fazenda a entrada era aqui, agora muda para outro rumo, já põe mais dificuldade pro boiadeiro. As veiz manda passá lá longe, tem muito fazendeiro que fala que boiadeiro é bagunceiro, que isso, que aquilo, mas não é assim não, vai muito é, isso é muito, sei lá (...). Ah tem muita mudança. Nesses lugar que as fazenda é dos paulistas teve muita mudança né... É o corredor, o tratamento é diferente, não é como os antigos daqui, memo do Pantanal. Você chega até o tratamento é diferente né, já não é como, a gente ta acostumado a viajar aqui, conhece todo mundo aí, mas você chega na fazenda que é povo estranho, de fora, já nota a diferença, né (...).

E fala muito, hoje em dia já não tem, mas antigamente que não existia corredor para ir embora para São Paulo, que era tudo cerradão, eles fazia muito dobrada né. Era 7 ou 8 peão na boiada e falava vamos cortar aqui assim, e saí em tal parte e cortava. Cortava aqui e ia saí lá. É dobrada que eles falava. A turma conhecia muito, conhecia, costumado todo ano passá ali, então falava, vamo cortá, saia em tal cabeceira lá, chegava tal hora, meio dia onze hora saia lá. Agora hoje em dia você não pode mais fazê isso porque vai atravessá, chega sai lá numa cerca, já dificulta, você tem mais é que ir pela estrada memo. Abriu um pouquinho assim, já vorta nela, já pega ela de novo, cê arriscá abri dela (...)

Um sistema muito interessante e próprio dos boiadeiros são as marcas que deixam na paisagem e que representa uma importante forma de linguagem (Tabela 6).

E outra, se você vê uma escrita não vai nem imaginar que foi um peão que escreveu ali. É por isso que ocê tem que ter malícia, né. Se você vê um pé de árvore com escrita ali, ocê tem que ter malícia que foi um peão de boiadeiro que escreveu. Geralmente peão de fazenda quase num escreve em pé de árvore, mais é peão de estrada memo. (BIGUÁ, 2009). 
Tabela 6 - Marcos referenciais na leitura da paisagem: marcas e escritos de boiadeiros.

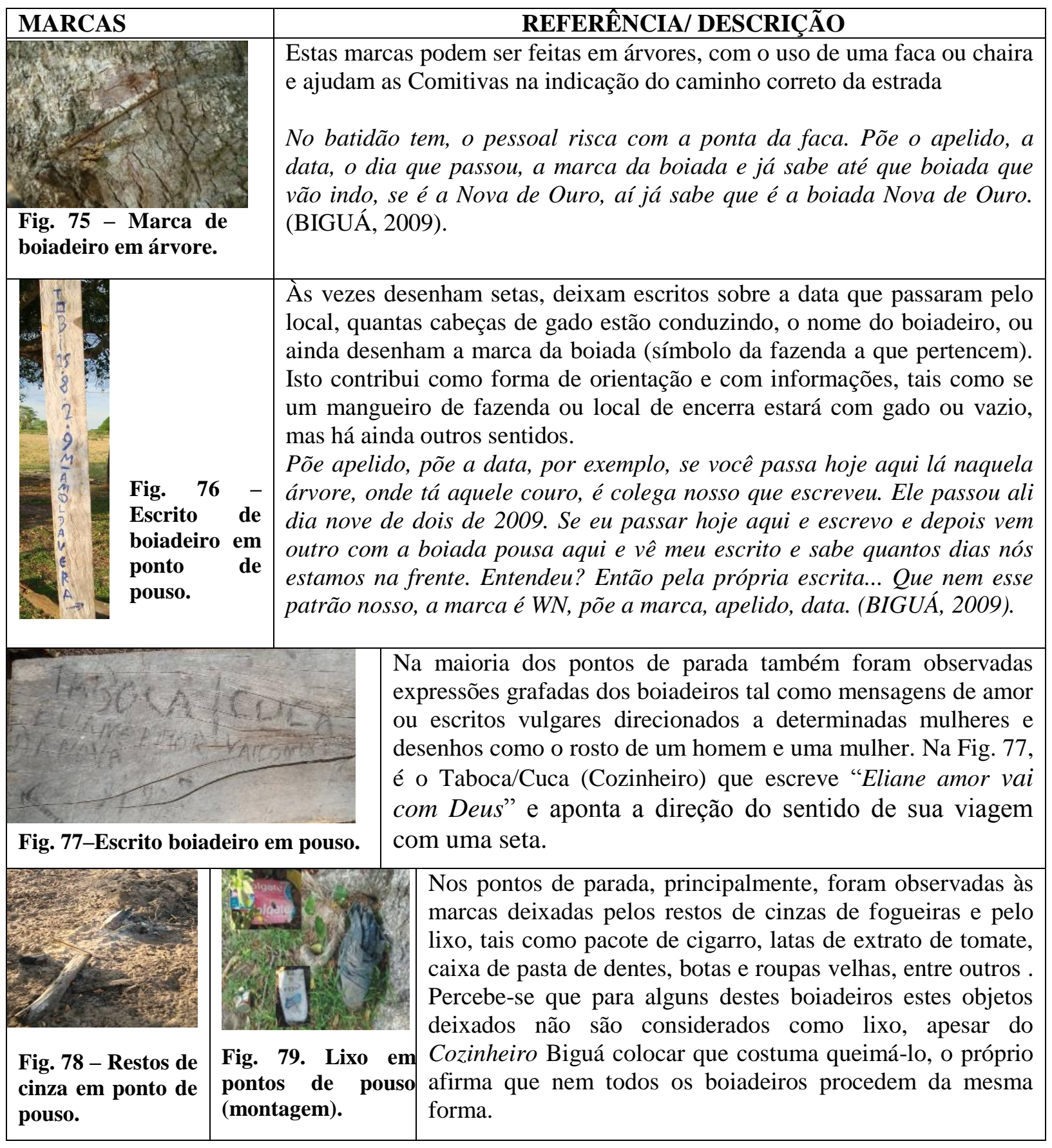

Talvez a maior freqüência observada de marcas ou escritos nos pontos de parada se deva também pela maior evidência e facilidade da pesquisadora em encontrá-las ${ }^{103}$, contudo nos

\footnotetext{
${ }^{103}$ Infelizmente, muitos dos escritos apresentados não foram claramente decifrados. Deve-se dizer ainda que estes foram fotografados por estarem em um pouso boiadeiro em frente ao local de moradia da pesquisadora, já que não foi possível visitar outros locais ou acompanhar outras Comitivas. Os boiadeiros provavelmente
} 
relatos orais identificou-se que há inúmeras formas desta comunicação, tal como aponta o discurso de Biguá (2009):

O povo, é mais conhecido é mais por ela, porque ela é mais batida, num tem como perdê, né, mas tem muitos que vem passando em fazenda e tal. Só quem não conhece memo, só que quem não conhece já pega a mestra memo, que os portão já é tudo marcado, né, aí vem por ela.

Agora tem lugar que não passa quase boi e fica mais difícil, Agora quando é batidão de boi não, mesmo com a estrada apagada assim, tem que ir prestando atenção lugar que você não conhece né. A estrada passa aqui, tem um pé de árvore ali, você dá uma olhada, tem escrito de peão. Se tem escrito de peão ta certo né. Você vai indo aqui, se você ver estrada apagada, escrita de nada fica meio veiaca, porque pode acontecer de estar errada né. E você vê nessa estrada que é difícil assim o peão já marca, já deixa marcado. Se o cozinheiro conhece ele vai na frente já quebra um galho de pau, faz um corte num pé de árvore e a turma que vem atrás já vem prestando atenção.

Atentos a quaisquer interferências e sinais, são capazes de perceber, por exemplo, se na estrada passou veículo, há quanto tempo, qual o tipo de veículo, e muitas vezes podem saber até mesmo a quem pertence. Certos acontecimentos também podem tornar-se referências, tais como: a laçada de uma rês que fugiu, uma queda de cavalo, a caça de um porco ou histórias de assombração.

É muito comentado na região que, apesar do isolamento, nada passa despercebido, pois há um rico sistema de informações, além do que, observou-se que os boiadeiros gostam de contar e saber sobre a vida alheia. E assim se comunicam, trocando informações com aqueles que estão nas fazendas ou cidades.

De forma geral, foram identificados também, os marcos referenciais relacionados as configurações da paisagem, tal como no que se refere à vegetação, à observação do comportamento de animais, ao relevo, de acordo com denominações dadas pelos boiadeiros. Nas tabelas abaixo, estão evidenciadas aquelas que foram mais citadas por fontes locais.

conseguiriam explicá-los melhor, mas deste período em diante não houve mais Comitivas (estação da cheia). Acredita-se que este possa ser um interessante tema para estudos futuros. No Apêndice D (p. 194), há mais fotos sobre destas marcas. 
Tabela 7 - Marcos referenciais na leitura da paisagem: vegetação

\begin{tabular}{|c|c|}
\hline VEGETAÇÃO & REFERÊNCIA/ DESCRIÇÃO \\
\hline $\begin{array}{l}\text { Pasto Nativo } \\
\text { Fig. 80 - Rabo de burro (A. bicornis). } \\
\text { Região Abobral. }\end{array}$ & $\begin{array}{l}\text { Outros exemplos de pasto nativo: Capim- Vermelho } \\
\text { (Andropogon hypgynus); Capim- mimoso (Axonopus } \\
\text { purpusii). } \\
\text { Estas pastagens nativas constituem fitofisionomias como o } \\
\text { Campo limpo e bordas de corpos de água. Está sujeito a } \\
\text { inundações periódicas. (SANTOS et al., 2008). }\end{array}$ \\
\hline $\begin{array}{l}\text { Fig. } 81 \\
\text { humidícula }\end{array}$ & $\begin{array}{l}\text { Só que do lado aqui não tem formado, não tem nada, na } \\
\text { maior parte, só que você não vai com o gado aqui na } \\
\text { estrada. (JUAREZ, 2007). } \\
\text { É o pasto cultivado, introduzido e exótico. No Pantanal, os } \\
\text { mais comuns são a braquiara (Brachiaria spp) e a } \\
\text { humidícula (Brachiaria humidicola-ilust. ao lado). } \\
\text { (SANTOS et al., 2008) }\end{array}$ \\
\hline Fig. 82-Ca & $\begin{array}{l}\text { Tipo, você vai para o Carandazal, é tem uma bitola ali, não } \\
\text { é cascalhada (...). (JUAREZ, 2007). } \\
\text { Caradandazal é uma fisionomia vegetal onde há abundância } \\
\text { de indivíduos da palmeira carandá (Copernicia alba). E } \\
\text { assim pode também ocorrer com outras formações como o } \\
\text { buritizal (Mauritia flexuosa); acurizal (Scheelea phalerata), } \\
\text { piuval (Tabebuia impetiginosa e T. heptaphyla). }\end{array}$ \\
\hline $\begin{array}{l}\text { Fig. } 83 \text { - Estrada com mato fechado. } \\
\text { Primeira Comitiva. } \\
\text { Aquidauana/ }\end{array}$ & $\begin{array}{l}\text { (...) um corredor sujo de mato, tem que ir } \\
\text { devagarzinho, tem que olha se não tem caminhão } \\
\text { parado na beira, por exemplo, atrás. (JUAREZ, 2007). } \\
\text { Tem lugar que ocê vai beirando o mato, tem veiz, a } \\
\text { estrada pega no meio do baixadão, do brejo, aí você } \\
\text { tem que ir beirando o mato, tem que ir } \\
\text { desviando.(BIGUÁ, 2009) } \\
\text { Mato fechado ou Mata é uma generalização equivalente na } \\
\text { literatura científica aos termos campo-cerrado, cerrado, ou } \\
\text { cerradão. Podem referir-se a mato sujo ou sujeira } \\
\text { significando um local desmatado, que está em inicial } \\
\text { estágio de sucessão e possui espinheiros, como a dormideira } \\
\text { (Mimosa invisa Mart), guelra de dourados (Senna aculeata), } \\
\text { Mercurinho (Sebastiania bidentata) ou ainda espécies } \\
\text { exóticas como a arumita (Acacia farnesiana). Campo sujo } \\
\text { refere-se a áreas invadidas por diversas espécies arbustivas } \\
\text { como canjiqueira, assa peixe, etc. (SANTOS et al., 2008) }\end{array}$ \\
\hline
\end{tabular}




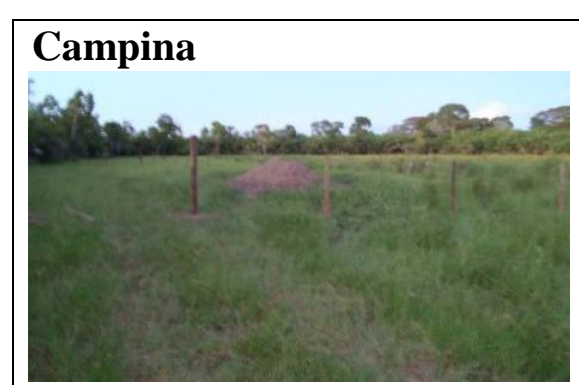

Fig. 84 - Campina. Faz. Nossa Senhora do Carmo.

\section{Cordilheira}

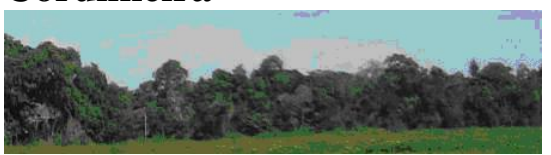

Fig. 86 - Cordilheira. Faz. Nossa Senhora do Carmo.

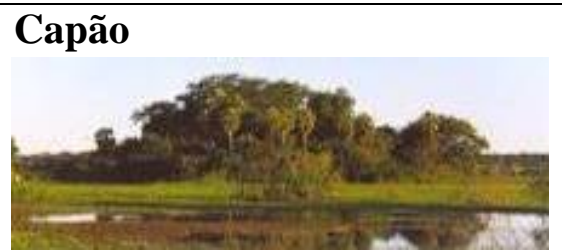

Fig. 87 - Capão. Refúgio Ecológico Caiman

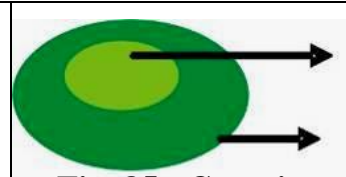

Fig. 85 - Campina
MATO: "Do mato, se sai num trilheiro e chega num aberto".

ABERTO: "Mais ou menos uns $100 \mathrm{~m}^{2}$. Normalmente é nativo, pode ocorrer de não ser, mas é dificil, porque é dificil pelo acesso".

Campina é um lugar onde ocê sai do mato, que quando ocê sai duma estradinha fechada, ocê sai num limpo, assim, um limpo pequeno. É uma campina. Um limpo se deixá cresce, é só mato de novo. Aí chegando naquela campina, você entra... (JUAREZ, 2009). ${ }^{104}$

São cordões arenosos sob vegetação de cerrado, com cota de aproximadamente um a dois metros superior à dos campo, geralmente não inundáveis. Cunha (1985 apud COMASTRI; POTT, 1996, p. 7)

Capão é uma ilha de mato, independente de estar em terreno mais elevado. Se forem muito grandes, passam a ser considerados capoeszões, capaolões. Se possuírem área pequena passam a ser denominados capõeszinhos, capãozinho. (CAMPO FILHO, 1998, p. 67).

Além do conhecimento sobre a vegetação contribuir na orientação dos boiadeiros, foi

observado que eles também a utilizam para outros meios, tais como o emprego de galhos e troncos de árvores secas para lenha; a Figueira (Ficus sp) e a leiteira (Sapium haematospermum) como bases para armarem lonas e redes. Já o raque (eixo foliar) e o pecíolo da palmeira Acuri (Scheelea phalerata) podem ser utilizados como espeto de churrasco.

Segundo Juarez (2009), há também uma brincadeira feita com

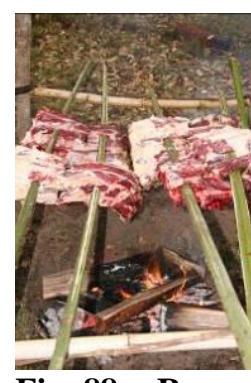

Fig. 88 - Raque e pecíolo de Acuri como espeto de churrasco. boiadeiros iniciantes: sugere-se que este amarre sua rede em uma árvore (novateiro - Triplaris americana), mas como ela é habitada por formigas, o jovem, inocentemente, acaba por tomar algumas mordidas bem doídas.

\footnotetext{
${ }^{104}$ A figura da campina, com as respectivas indicações textuais, foi elaborada pelo entrevistado Juarez e desenhada pela pesquisadora, buscando ser o mais fiel possível à orientação do mesmo.
} 
Durante as viagens, os boiadeiros podem utilizar-se de plantas medicinais, até porque, às vezes, não há outro recurso como remédio. Segundo fontes orais, há uma forma específica para a ingestão dessas plantas, sendo necessário colocá-las em um copo com água, masserar e deixar a mistura no sereno em uma noite de lua nova, para que exerça o efeito desejado.

Tabela 8 - Exemplos de plantas medicinais e formas de utilização citadas pelos boiadeiros.

Fig. 89- Fedegoso (Cassia occidentalis
L.):
Raiz utilizada como vermífugo, para
problemas gastroentestinais e anemia.

Outras referências apontadas pelos boiadeiros ocorrem por meio da observação do comportamento de animais silvestres e domesticados (Tablea 9). Durante o acompanhamento das Comitivas notou-se que os boiadeiros estão sempre atentos aos sinais dos animais e possuem uma percepção acurada. Visão, olfato e audição são sensíveis para perceberem, facilmente, pegadas, cheiros e sons dos animais, tendo em vista que a presença de cobras e onças podem assustar a tropa e a boiada, conforme relatos descritos por eles.

Tabela 9 - Marcos Referenciais na leitura da paisagem: exemplos de animais

\begin{tabular}{|l|l|}
\hline ANIMAL (ESPÉCIE) & DESCRIÇÃo \\
\hline $\begin{array}{l}\text { Fig. 92- Caramujo Aruá } \\
\text { (Pomacea sp) }\end{array}$ & $\begin{array}{l}\text { A posição dos ovos deste caramujo em } \\
\text { determinada altura indica que o nível das águas não } \\
\text { irá subir acima do local de postura. }\end{array}$ \\
\hline
\end{tabular}




\begin{tabular}{|c|c|c|}
\hline $\begin{array}{l}\text { Fig. 93- Tachã } \\
\text { (Chauna torquata) }\end{array}$ & & $\begin{array}{l}\text { A vocalização desta ave significa que há pessoas se } \\
\text { aproximando, podendo auxiliar o Cozinheiro da } \\
\text { Comitiva com a interpretação de que os boiadeiros } \\
\text { estão chegando ao ponto de parada. }\end{array}$ \\
\hline $\begin{array}{l}\text { Fig. 94- Saracura Três- } \\
\text { potes (Aramide scajanea) }\end{array}$ & $\begin{array}{l}\text { Fig.95- Bugio } \\
\text { (Alouatta caraya) }\end{array}$ & $\begin{array}{l}\text { A vocalização do bugio ou da saracura significa } \\
\text { para os boiadeiros que haverá alguma alteração } \\
\text { meteorológica. }\end{array}$ \\
\hline $\begin{array}{l}\text { Fig. 96- Tropa de burros } \\
\text { (Equus asinus) }\end{array}$ & & $\begin{array}{l}\text { Muitas vezes a tropa de burros da Comitiva } \\
\text { conhece o caminho da estrada, principalmente o } \\
\text { polaqueiro, que guia a tropa e a tropa cargueira. } \\
\text { Assim, ajudam na orientação dos boiadeiros. }\end{array}$ \\
\hline $\begin{array}{l}\text { Fig. 97- Cupins } \\
\text { (Cornitermes cumulans e } \\
\text { outras espécies.) }\end{array}$ & & $\begin{array}{l}\text { Quando ocorre a revoada das aleluias (reprodutor } \\
\text { alado) significa que o tempo das águas está } \\
\text { chegando. }\end{array}$ \\
\hline
\end{tabular}

Na segunda Comitiva, em um local alagado, próximo ao Rio Negro, o Condutor sutilmente percebeu a boiada inquieta e prestando um pouco mais de atenção, escutou esturros de onça, que minutos depois também foram notados pela pesquisadora, por estarmos mais próximos do animal. Esta atenção é extremamente importante, durante a condução da boiada. Os burros também são muito sensíveis a presença de onças (Panthera onca - pintada ou Puma concolor - parda) e suas reações, tal como ficar ofegante e com orelhas erguidas também ajudam os boiadeiros na detecção de animais estranhos à tropa.

Alguns destes animais foram citados também por Nogueira (2002) e Banducci Junior (1995). A primeira autora coloca para os pantaneiros as garças ${ }^{105} \mathrm{em}$ locais altos e grandes volumes de camalote ${ }^{106}$ correndo rio abaixo são sinais de enchente. Banducci Junior (1995) também acrescenta que os pantaneiros extraem informações valiosas sobre mudanças eminentes no clima e nas estações.

\footnotetext{
${ }^{105}$ Espécie não especificada pela autora.

106 Camalotes são bancos de macrófitas flutuantes, conectados ao solo ou não ancorados. É um verdadeiro ecossistema, constituído por várias espécies, mas principalmente Oxycayum cubense e Eleocharis mutata.
} 
Pode-se observar também a presença dessa prática de observação dos animais no seguinte trecho do poema do pantaneiro Manoel de Barros (1990, p. 105):

Chegava um dia

O homem encontrava cobras dormindo na canga dos bois.

- Sinal de enchente... resmungava...e dispois grande!

(...)

Vaqueiros vinham sentar-se à porta do galpão

Olhando as nuvens...

Apesar dos boiadeiros não relatarem referências acerca de observações astronômicas, uma única estrela foi bastante comentada como indicadora do horário para levantarem-se, a estrela Dalva. É interessante que esta estrela, é para eles denominada de estrela Boiadeira, porém o entrevistado Biguá comenta que boiadeiros antepassados eram melhores observadores destas referências e compara-as com aquelas relacionadas às mudanças de tempo.

Que o povo, antigamente era mais assim, né, vivia muito pela, prestando atenção nas coisas, né, mudança de tempo, essas coisas assim, né. E até para levantá, levantava pela estrela, estrela Dalva, estrela Boiadeira, que eles falava assim, né. O povo antigo sempre de madrugada levantava pela estrela (...) que levanta madrugada levanta por ela né. Ela tá numa altura no céu assim, aí se ela ta naquela altura, assim, cê carcula ali, fala tá no horário, ah, tá no horário, são tantas horas. (...). As veiz, quatro horas, ela ta mais ou menos numa altura pra cima do garpão ali, e pode levantá que é quatro hora, quatro e meia. E a estrela Dalva é a estrela Boiadeira, que a gente sempre levanta por ela né. (BIGUÁ, 2009).

Sobre referências relacionadas à percepção do relevo no Pantanal, não é tão comum os boiadeiros se referirem a altitudes, tendo em vista que este praticamente não se altera. São mais empregados os termos sobre as formações aquáticas (Tabela 10) ou vegetações (Tabela 6) resultantes da sutil variação de altitude, como por exemplo, as baixadas, os campos altos e baixos e mesmo os capões e cordilheiras que são mais elevados do que suas adjacências, de um a dois metros. Uma referência citada no depoimento de Biguá (2009) foi o campo alto: “ $O$ rio Negro, atravesso ele, que em Janeiro já ta nadando já, você nadô ele ali, saiu na Buriti, é Nhecolância, já é campo alto já, porque o rio ele deságua pra cá”. 
Referências em relação ao solo foram pouco citadas, com exceção do areião e dos solos relacionados às vazantes e brejos, sendo então, comentados de forma indireta.

Tabela 10 - Marcos referenciais na leitura da paisagem: solos e relevo

\begin{tabular}{|l|l|}
\hline SOLO E RELEVO & DESCRIÇão \\
\hline & $\begin{array}{l}\text { Este tipo de solo foi o único citado pelas fontes orais, acreditando-se } \\
\text { que deva haver outras referências. } \\
\text { Também foi observado, durante a terceira Comitiva, que após a } \\
\text { travessia do rio Negro a Comitiva passou por uma extensa faixa de } \\
\text { solo branco arenoso, próximo ao retiro Santa Onofre (Faz. Santa } \\
\text { Filomena). }\end{array}$ \\
$\begin{array}{l}\text { Fig. 98 - Areião. Retiro Santo } \\
\text { Onofre. Faz. Santa Filomena. }\end{array}$ & $\begin{array}{l}\text { Durante a segunda Comitiva, em 2006, pousamos uma noite, } \\
\text { próximos ao Morro do azeite, que está localizado na BR 263 entre os } \\
\text { Municípios de Corumbá e Miranda. Segundo um dos Meeiros desta } \\
\text { viagem, este nome é devido a um óleo que "brota" do morro. }\end{array}$ \\
\hline $\begin{array}{l}\text { Fig. 99 - Morro do Azeite. } \\
\text { Fonte: Eric de Vito (2009). }\end{array}$ & \\
\hline
\end{tabular}

Uma categoria topofilica ${ }^{107}$ percebida é a afeição dos boiadeiros por lugares amplos, no que concerne a beleza de áreas abertas, campos abertos e largões (Fig.100). Campos Filho

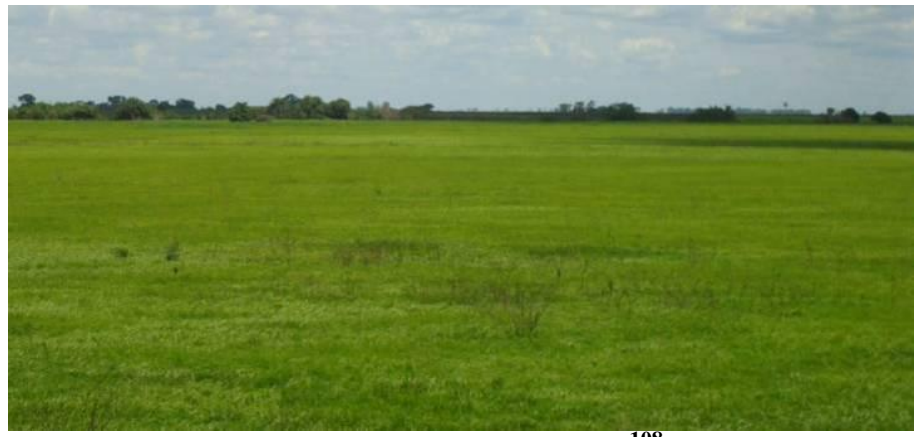

Fig. 100 - Campo aberto. Estrada Parque. ${ }^{108}$
(2002, p. 54, 93) descreve que o termo "'largo' é um 'grande campo limpo"” e que no passado 'eram largões sem fim', mas atualmente, mesmo medindo muitos quilômetros

de extensão, encontram-se fragmentados, havendo ainda o sujamento dos mesmos.

\footnotetext{
${ }^{107}$ Cf. Tuan, 1980.

${ }^{108}$ A Estrada-Parque-Pantanal, é uma Unidade de Conservação com 120 quilômetros de extensão e conta com mais de 80 pontes, incluindo a transposição da balsa do rio Paraguai. Essa estrada faz a ligação das cidades de Ladário e Corumbá com o entroncamento da BR-262, em um local denominado Buraco das Piranhas, onde existe um Posto da Polícia Militar Ambiental, próximo ao Morro do Azeite. A Estrada-Parque-Pantanal foi decretada como Área Especial de Interesse Turístico pelo Governo do Estado de Mato Grosso do Sul no ano de 1993 (WWF, 2002)
} 
Identifica-se que há uma contemplação da grandeza, imensidão destas paisagens de planície marcando uma infinitude do espaço íntimo, que traz um valor onírico particular. Esta preferência contrasta-se com a afeição por capões, cordilheiras e mato sujo, como algo que não faz parte do eu. Talvez as árvores possuam, para eles, certa referência de abrigo, pois alguns pousos são feitos sob as mesmas, mas parece que estas têm um sentido maior de utilidade do que intimidade e afeto. Banducci Junior (1995, p. 150) também coloca sobre a preferência dos pantaneiros "aos campos largos, onde é "mais limpo e tem mais vista", o que acredita remeter a liberdade. Outro apontamento interessante deste autor é que os pantaneiros entendem a palavra paisagem como "vista".

Ainda sobre este sentimento de amplitude, Bachelard (19?-, p. 139) contribui dizendo que "a imensidão está em nós. Está presa a uma espécie de expansão do ser que a vida refreia, que a prudência detêm, mas que volta de novo na solidão. (...) A imensidão é o movimento do homem imóvel". Este simbolismo de intensidade do ser também pode ser remetido a mundão e estradão, é a extensão do ser que se movimenta num vasto mundo, sem limites frente a um sentimento de solidão "do homem que medita diante de um universo infinito" (Ibid, p.140).

Apesar dos marcos referenciais terem sido apresentados nesta pesquisa, em tabelas separadas, é importante ressaltar que a leitura da paisagem pelos boiadeiros é feita de forma integrada. Percebe-se ainda, que estes referenciais estão imbuídos de histórias, envolvendo questões que, por vezes, podem ser conflituosas e contraditórias. Portanto, para compreender um pouco sobre estas referências nas paisagens deve-se considerar tanto impressões de leituras, como expressões do ser, que sofrem múltiplas influências e conformações de processos naturais e humanos em constante transformação. São mudanças advindas de construções e reconstruções no modo de vida dos boiadeiros, que interagem com as diversas paisagens, assim como a dinâmica das águas no pantanal. 
Esta análise contribui para a compreensão de que as leituras dos boiadeiros se exprimem por meio de linguagens intersubjetivas, estreitamente relacionadas às paisagens pantaneiras.

\subsection{No ritmo das águas}

Ao longo de conversas e entrevistas notou-se o quão marcante é a questão da água para a vida dos boiadeiros e moradores locais, e ainda, mais especificamente no que se refere ao ciclo das águas no Pantanal relacionado à enchente, cheia, vazante e seca. Dependendo do nível destas, ou seja, dependendo dos níveis dos rios e áreas alagadas, as Comitivas podem ou não ocorrer. E na maioria das vezes é por meio da leitura das estações que os trajetos de viagem são definidos ou alterados.

Tem a ver com a água [roteiro], se tivesse cheio que nem essa época agora, era muito difícil de tá passando aqui, por causo que tem muito brejo aí, fundo memo, e nada e é muita água, ia andá só n'água aí, uns 3, 4 dias, já, só direto n'água, aí já é mais difícil pra andá. Na seca agora tá passando, cê vê que tá passando carro, direto, tudo aí, tá seco, você não acha água pra nada aí.(BIGUÁ, 2009).

Todo dia a rotina dos boiadeiros se repete, mas o caminho é repleto de imprevistos.

Durante as estações do ano as paisagens pantaneiras por onde marcham se modificam e cada época exige dos boiadeiros destrezas distintas.

É quando começa a encher, né, sempre por janeiro, dia 20 de janeiro é a época que está chegando a água, porque a água para chegar aí é rapidão. De uma hora pra outra já é um mar de água. Em janeiro sempre tá movimentando, tá pegando, aí é só uma marcha só, a água feia memo é só uma marcha memo, só o primeiro dia, da São Carlos pra í na Buriti, aí cê atravessou o Rio Negro, o Rio Negro você atravessa ele assim. (BIGUÁ, 2009).

Quando os boiadeiros encontram alguém pelo caminho, ou quando chegam às fazendas, a conversa gira em torno de informações e previsões de uma água que vem vindo lá de cima, 
ou que aquele ou outro rio encheu e tá jogando água pra fora. Foi percebido que há um sistema de comunicação ${ }^{109}$ entre os viajantes das estradas, fazendeiros e moradores locais, para ser decidido qual o melhor caminho a ser seguido, de acordo com as estações.

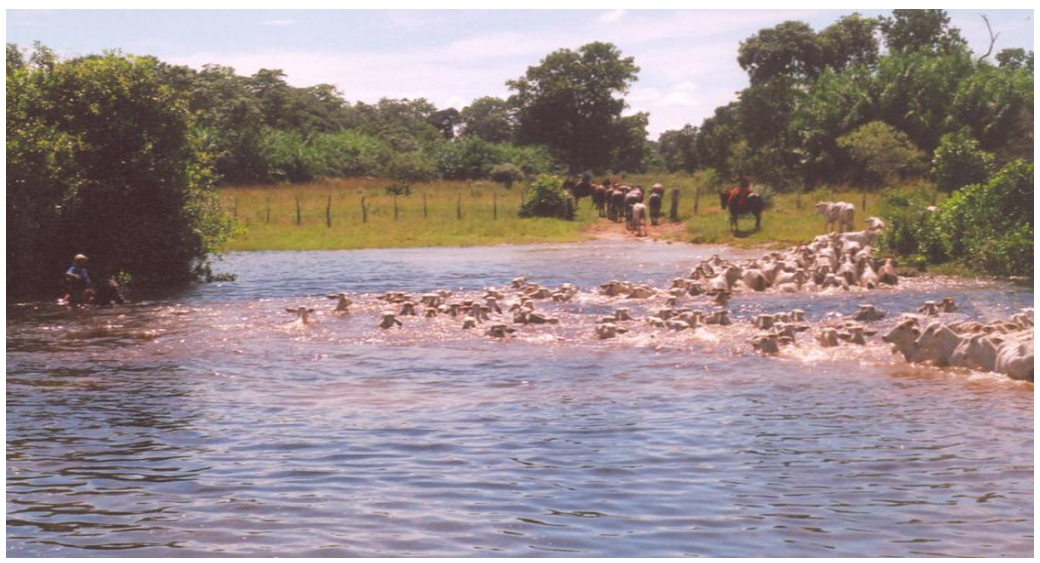

Fig. 101 - Bola pé. Travessia boiada no rio Cerradinho. Segunda Comitiva. Fazenda Fátima.
As paisagens aquáticas são importantes referências para o boiadeiro e, o nível da água é externalizado, por exemplo, por meio das seguintes expressões: o gadão tá

nadano, lá é lugar de nado, tá molhando a ponta do pelego, ou que a água cortô a estrada. “Eles fala, quando tá muito cheio, já explica lugar que tá nadano e tal, aí já explica o lugar que tá melhor de passá, tem que ir (...)”. (BIGUÁ, 2009).

Esta medição de profundidade do corpo d'água, realizado por meio destas formas de linguagem, é que irá determinar a maneira e o local da travessia. Outro exemplo de expressão utilizada foi observada durante a segunda Comitiva, antes de se atravessar o rio Cerradinho, quando houve o comentário que ia dar bola pé (Fig.101). Isto significa que a tropa iria ter que atravessar o rio através de movimento intermediário ao nadar e caminhar.

Atravessou ele, em janeiro já ta nadano já. Tem uma beira ali, que saiu na Buriti já é campo alto já, já pega é campo alto, pega água, vazante, mas não é quem nem o, esse pedacinho da São Carlos pra cê saí no rio aí tem, cêe nada, tem uns 3 ou 4 corixo que nada, bola pé. Pegô o rio... (BIGUÁ, 2009).

Segue abaixo, uma tabela com mais alguns exemplos de marcos referênciais relacionados as paisagens aquáticas:

\footnotetext{
109 Sobre estes sitemas de comunicação, ver Bigatão (2009).
} 
Tabela 11 - Marcos referenciais na leitura da paisagem: paisagens aquáticas

\begin{tabular}{|c|c|}
\hline PAISAGENS AQUÁTICAS & DESCRIÇÃ̃O \\
\hline $\begin{array}{l}\text { Fig. } 102 \text { - Vazante Cerradinho. Faz. Nossa } \\
\text { Senhora do Carmo. }\end{array}$ & $\begin{array}{l}\text { Pega água de brejo, baía, vazante, mas já não tem } \\
\text { bacia assim (...) é Nhecolândia. (BIGUÁ, 2009). } \\
\text { (...) num tem aquele aguacero igual tem na São } \\
\text { Carlos, aí parece que é uma bacia, esse trecho aqui é } \\
\text { uma bacia, né. Daí ocê passo a São Carlo, saiu no } \\
\text { campo da Buriti, Santa Onofre, ali tudo é arto. } \\
\text { (BIGUÁ, 2009). }\end{array}$ \\
\hline $\begin{array}{l}\text { Fig. } 103 \text { - Rio Paraguai. Porto da Manga. } \\
\text { Embarcadouro de gado. }\end{array}$ & $\begin{array}{l}\text { Ah, nós vamo pegá lá na fazenda, ah, vamo supor, na } \\
\text { Sebastião Grande, fica lá do lado de lá do } \\
\text { Taquari.(...). Taquari é o rio. Aí você já, aí você como } \\
\text { é um peão viajado, você já, tem muitos que já conhece } \\
\text { tudinho esses pouso. Aí o cara fala, nóis vamo lá pelo } \\
\text { Taquari (JUAREZ, 2009) }\end{array}$ \\
\hline $\begin{array}{l}\text { Fig. } 104 \text { - Corixo do inferno. Faz. Nossa } \\
\text { Senhora do Carmo. }\end{array}$ & $\begin{array}{l}\text { E talveiz, pra saí aqui nessa região, na Nossa Senhora } \\
\text { do Carmo, ocê vim por aqui, aqui também quando tá } \\
\text { cheio já é difícil passá aí também, tem muita água no } \\
\text { corixo fundo e já vai mais pelo Japorá e dá mais a } \\
\text { vorta por lá, né. (BIGUÁ, 2009) } \\
\text { Corixo é um canal em declive, que depende da } \\
\text { inundação. Às vezes são nomeados como corixo fundo, } \\
\text { corixão, etc. } \\
\text { Nem sempre perenes despraiam em vazantes, baixios, } \\
\text { brejos, baías ou desagüam em um corpo d'água. } \\
\text { (CAMPOS FILHO, 1998). }\end{array}$ \\
\hline
\end{tabular}

Outras referências em rios e corixos são os lugares onde se atravessa com a boiada, chamados de passagem. Segundo Campo Filho (1998:128), estas travessias podem causar o estrangulamento na drenagem do rio, como no caso citado do Rio Bento Gomes (MT): “Os outros dois pontos, por serem locais de passagem, denotam como seu agente, o gado, que erodiu o barranco arenoso, entupindo o rio."

Este autor apresenta uma abordagem da paisagem pela cultura pantaneira na região de Poconé (MT), mas é interessante que esta se difere em certos momentos da abordagem da presente pesquisa, provavelmente, devido a regionalismos. 
Há controvérsias sobre qual época do ano é mais complicado viajar tangendo boiadas.

Segundo alguns boiadeiros, conduzir Comitivas na seca é o que há de mais difícil, pois fora a poeira na estrada, há chances de ficarem períodos sem água. Entretanto ao que tudo indica, para a maioria destes a pior época é a cheia. O experiente Cozinheiro Biguá (2009) completa que "o pantanal é, ele é ingrato dos dois lado”, ou seja, tanto na seca, como na cheia.

O Pantanal, ele é bom agora, de agora até três meses, uns dois meses para frente. Agora nós vamos entrar setembro, outubro, novembro, né, uns três meis ele tá bom de viajá. Porque agora vai começar a chover, vai juntá água nas baixadas. Junta água nas baixadas e você tem água para fazer almoço, para o gado beber, e fica bom, não tem corixo pra moiá a traia, pra nadá, nem nada. Mais aí passou pra frente aí, já começa a alagá tudo e fica difícil. (...) Você trabalha tudo, mas tem dificuldade, já demora mais para você andar aí, do que se andá no seco, demora (...) para andar aí. Ah, na cheia, na cheia é pior, gado sente muito, a tropa, cê trabaia dobrado, traia tudo moiado, apodrece tuda a traia, gado sente muito.(BIGUÁ, 2009).

Na uma tabela abaixo, segue algumas das diferenciações apontadas nos relatos orais, entre as duas estações da cheia e da seca.

Tabela 12 - Diferenças entre o ciclo das águas (cheia e seca) e seus significados para boiadeiros

\begin{tabular}{|c|c|c|}
\hline \multicolumn{3}{|c|}{ CICLO DAS ÁGUAS } \\
\hline DIFERENÇAS & CHEIA & SECA \\
\hline \multirow[t]{2}{*}{ Roteiro } & $\begin{array}{l}\text { Muda-se o roteiro para passar por } \\
\text { áreas menos alagadas. }\end{array}$ & $\begin{array}{l}\text { Muda-se o roteiro para encontrar } \\
\text { água. }\end{array}$ \\
\hline & \multicolumn{2}{|c|}{$\begin{array}{l}\text { Isso, na época da seca, na época da cheia você muda pra você pegar menas } \\
\text { água, e na época da seca, você muda pra achar água. (JUAREZ, 2007). }\end{array}$} \\
\hline \multirow[t]{2}{*}{$\begin{array}{l}\text { Cotidiano e } \\
\text { Sofrimento }\end{array}$} & $\begin{array}{l}\text { Sofrem muito pra chegar ao pouso, } \\
\text { principalmente porque se molham, e } \\
\text { podem molhar também a traia. } \\
\text { Basicamente, passa-se a maior parte } \\
\text { do tempo molhado e dorme-se mal. }\end{array}$ & $\begin{array}{l}\text { Há muita poeira na estrada. } \\
\text { Chega-se no pouso, ou no almoço } \\
\text { branco de poeira. Na seca é mais } \\
\text { difícil encontrar água para tomar } \\
\text { banho. }\end{array}$ \\
\hline & \multicolumn{2}{|c|}{$\begin{array}{l}\text { Então, é mai difícil, é um serviço muito chato, sofrido memo, sofrido, é ocê toma } \\
\text { chuva, talveiz cê chega num ponto de armoço, tá chuvendo, num tem garpão, } \\
\text { ocê tem que durmí ali, por isso que ocê já tem que sair preparado na viagem. } \\
\text { Tudo que tem, que viaja direto tem aquela torda, né, uma torda que põe em } \\
\text { cima da rede, assim, uma lona. (BARRIGA, 2007). }\end{array}$} \\
\hline $\begin{array}{l}\text { Procedimentos } \\
\text { Adotados }\end{array}$ & $\begin{array}{l}\text { Não esperam a chuva passar, o } \\
\text { burro é pego e encilhado mesmo na } \\
\text { chuva. Portanto, não importa se está } \\
\text { chovendo, quando chegam tem que } \\
\text { desencilhar e montar seu } \\
\text { acampamento. Há uma regra, como } \\
\text { em um quartel. }\end{array}$ & $\begin{array}{l}\text { O Cozinheiro tem dificuldade pra } \\
\text { achar água e conforme a distância } \\
\text { que a encontra, pode atrasar muito } \\
\text { o horário do almoço, e assim } \\
\text { também a chegada ao pouso. Às } \\
\text { vezes podem até não almoçar. }\end{array}$ \\
\hline
\end{tabular}




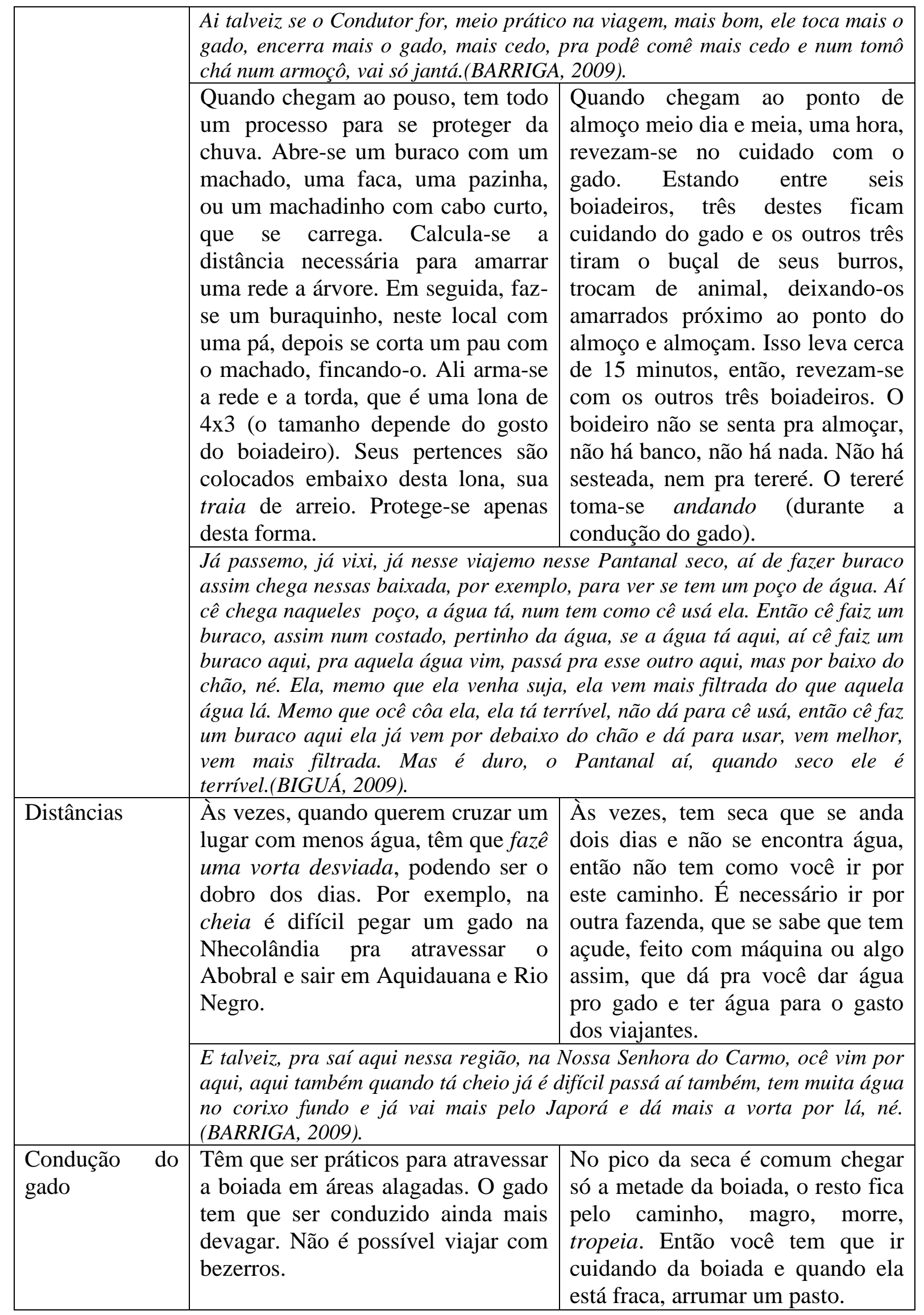




\begin{tabular}{|l|l|}
\hline Então em isso aí, num vai pegá e sai, 40 dias num lugar, numa época, ainda \\
mais no meio da seca, sai, cê num chega lá, a hora que ocê chega, é só metade, \\
o resto fica pelo caminho, magro, morre, tropeia? Então você tem que ir \\
cuidando a boiada, quando ela ta fraca, ocê arruma um pasto, se arruma um \\
pastoreio pra ela, e dá pasto.(JUAREZ, 2009).
\end{tabular}

Foi percebido que há um sentido conflitante sobre a questão da água, pois apesar dos problemas relatados durante a cheia, que representam várias dificuldades durante as viagens, a chegada do tempo das águas também possui sentido de purificação e limpeza. Segundo Seu Zé Preto, a água da cheia limpa o pasto. Em junho de 2009, este senhor estava doente, acusando como causa a escassez de água. Ele também colocou que a falta desta é prejudicial e traz doenças, como a peste (o mal das cadeiras) ${ }^{110}$.

Segundo Diegues (2006) ${ }^{111}$ tudo aquilo que não é material, as sensações, impressões, incluem-se como elementos simbólicos. Nesse sentido, sugere-se, para fins desta dissertação, classificar (ou considerar) a água como um dos elementos simbólicos para os boiadeiros.

Além da dificuldade na travessia de rios e áreas alagadas os boiadeiros sofrem por estar constantemente com suas tralhas e roupas molhadas. No período de estiagem, a situação se inverte e a preocupação com a escassez de água não é somente para consumo próprio, mas também para a boiada e a tropa.

Na estação da cheia foi relatado por fontes orais que é mais difícil se localizarem, assim afirma Biguá (2009) : “Ah muda, muda que porque diferencia, né. A água estraga muito”.

No acompanhamento da terceira Comitiva, durante o primeiro dia de viagem, optou-se por acompanhar o Cozinheiro Dourado. Como ele não conhecia o percurso até o ponto de almoço, o Condutor solicitou para que o Fiador Luciano (apelido de Gordinho) ${ }^{112}$ o

\footnotetext{
${ }^{110} \mathrm{O}$ mal das cadeiras é uma doença que afeta diversos mamíferos silvestres e domésticos, como capivaras, veados, cães, cavalos, etc. Os sintomas são anemia, fraqueza, edemas nas partes inferiores do corpo, podendo levar a morte. É causada pelo Trypanosoma evansi, no Pantanal o principal vetor de transmissão é o Tabanus importunus (mutuca). Nesta mesma época (Junho de 2009) estava ocorrendo uma epidemia da doença. (VIEIRA et al., 2004).

${ }^{111}$ DIEGUES, A. C. Anotações de aula, da disciplina "Imagens da Natureza: Representações Simbólicas do Mundo Natural", ministrada no segundo semestre de 2006

${ }^{112}$ Luciano era chamado pelo seu apelido, Gordinho. Na data da Comitiva tinha por volta de 16 anos e era a segunda vez que viajava por esta estrada.
} 
acompanhasse, pois este disse que conhecia o caminho. Durante este trajeto, havia uma vazante de água com duas opções de acesso, mas o jovem optou pelo acesso errado, o que na verdade, também chegaria ao pouso, mas demoraria mais tempo. O Cozinheiro, mais experiente, logo percebeu que o caminho estava errado, somente porque viu um batidão da boiada anterior que havia passado, na outra entrada da vazante. Gordinho foi à frente procurar se era este o caminho, enquanto ficamos esperando com a tropa cargueira. Como a boiada se aproximou de nós e os outros boiadeiros sabiam o caminho, eles mesmos nos indicaram. Ao final da travessia da vazante encontramos Gordinho novamente. Este acontecimento fez gerar crítica de todos os viajantes, principalmente do Dourado, que estava preocupado com o atraso no jantar e cansaço da tropa. Os outros reclamaram que era um absurdo que ele tivesse se perdido, e que se ele não sabia o caminho, não deveria ter dito que sabia. Gordinho justificou que o caminho estava diferente, pois da última vez havia menos água na estrada.

A partir desta experiência foi possível sentir que além de no período das águas ser mais difícil se localizar, exige-se habilidades diferentes, pois as marcas na estrada tornam-se menos visíveis. No caso relatado acima, talvez o jovem não tenha observado o "batidão" da boiada pela falta de experiência, assim como coloca Biguá (2009): “Ah perde, cê vai de fazenda em fazenda, tem lugar memo, que é só batidão de boi memo”.

Porém, a atenção deve ser permanente, independente da sazonalidade das águas, principalmente quando se está conduzindo grandes quantidades de gado.

Tem muito, não é todo lugar que dá pra você cruzá na estrada, as veiz memo tando seco, né. Ás vezes a estrada vai assim, aí você vê que a estrada faz um vortão assim. Você não vai andá toda a vida pela estrada sendo que dá para cortar, corta aqui, a boiada vai comendo, tranqüilo, cê sai sai lá na frente, né. Tem que í prestando atenção só no rumo da estrada, né, porque talveiz, você pensa que ela vai lá, ela vai pra otro rumo. Então você tem que ir sempre prestando a atenção né. De vez em quando o Ponteiro deixa a turma segurando ali, vai, dá uma vortinha sempre tá cuidando a estrada, o rumo dela, porque senão ela vai aqui, cê tora aqui, de repente ela, tá um pouco ruim, mas cê até cê chega, as veiz o mato vai assim, e se chega lá na frente você num breca lá, cê não tem como cê vortá, aí até ocê vortá com um 
mundo de boiada aqui, cê pega a estrada de novo, atrasa pra caramba. Então, tem uns lugares num breca, ocê não pode ir metendo as caras, em quarqué lugá. Pouquinho gado não, poquinho gado cê vai, quarqué lugá, lugarzinho apertado, até vará, com 1000 boi aí, já perde hora. (BIGUÁ, 2009).

Alguns boiadeiros relataram que, no Pantanal, há locais onde se encontra água fazendo buracos de poucos centímetros de profundidade ou para encontrá-la podem utiliza-se um graveto em formato de Y para sondar água. Em pé, segurando este graveto com as duas mãos pode-se sentir uma vibração quando se passa próximo a um local com água no solo, facilitando assim, encontrar o local a ser perfurado. Biguá (2009) apesar de saber sobre esta técnica, disse que não a utiliza:

O povo tem essa lenda aí, mas eu mesmo nunca usei. O povo fala que com uma arame, um pedacinho de arame, ocê com um pedaço de arame, cê testa ali, esta, nesses pé de piúva, tem esses pé de piúva pantaneira, com um pedaço de arame ocê testa água, se tiver água tiver perto, diz que o arame mexe. Para mim isso é uma lenda, né. Eu nunca tentei.

Podem-se identificar dois recortes expressivos na interação das Comitivas de boiadeiros e a dinâmica das águas no Pantanal. O primeiro está relacionado às práticas executadas, mais especificamente a definição dos trajetos de viagem, que dependem diretamente nível das águas. Já o segundo recorte está ligado ao mundo simbólico dos boiadeiros, que incluem os significados que emergem do real vivido e que muitas vezes exprimem tensões sobre a idéia de água, o que parece refletir devido as extremas condições das estações climáticas. Cabe ainda dizer que ambos recortes são indissociáveis e representam o tipo cultural do boiadeiro.

As análises neste capítulo permitem revelar que a leitura das paisagens pantaneiras pelos boiadeiros é diretamente relacionada ao significado de lugar e expressam-se por meio de marcos referenciais, primordiais para orientação nas viagens de Comitivas. Além disto, a leitura do ciclo das águas no Pantanal é imprescindível à forma de execução das Comitivas e compreende tanto questões relacionadas à funções práticas quanto ao universo vivido e experienciado dos boiadeiros. São pequenos mundos que se criam no decorrer destes trajetos. 
Portanto, a comunicação que os boiadeiros estabelecem localiza-se "no centro do eu e do outro e da emergência de identidades individuais e coletivas” Claval (2001 apud ERIKSON, 1972; LÉVI-STRAUSS, 1977; HAMPSON, 1982).

Quaisquer análises, seja sobre o universo cultural do boiadeiro ou sobre as paisagens no Pantanal, devem ser percebidas como fenômenos que interagem todo o tempo e integramse como fenômenos totais. 


\section{CAPÍTULO 4: APROXIMAÇÕES PARA UMA CONCLUSÃO}

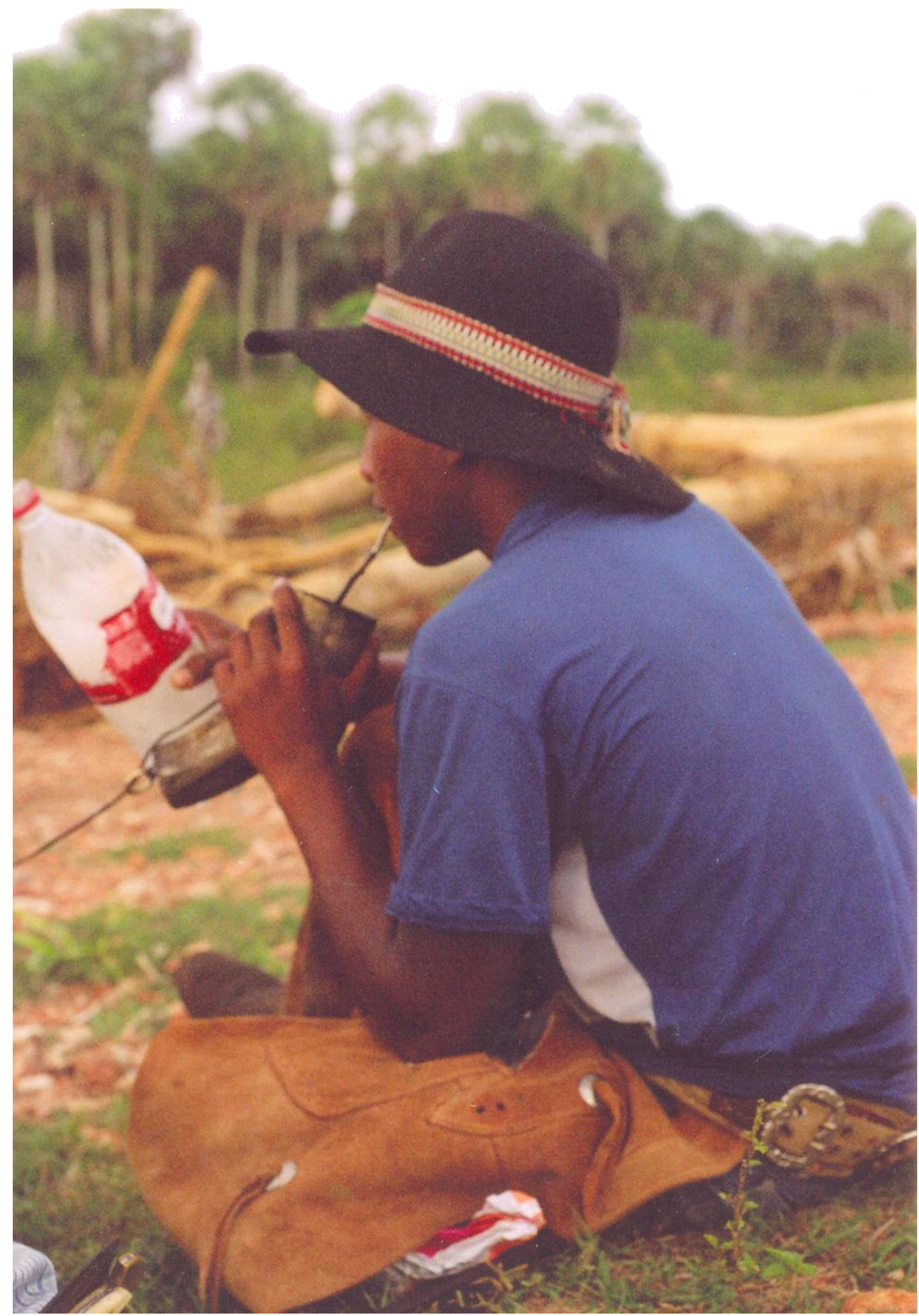

Fig. 105. Marcos Antonio Vaca (Babuíno). Segunda Comitva. Carandazal. 
As Comitivas de boiadeiros representam no mundo, uma prática milenar de transporte de gado para fins comerciais ou de subsistência. É possível que haja similaridades entre esta forma de manejo, executada tanto em regiões do Brasil, quanto em diferentes países ${ }^{113}$, porém a interpretação dos dados, nesta pesquisa, revela que os boiadeiros representam um tipo cultural associado ao Complexo Pantanal Sul-Matogrossense. Assim, buscou-se desvendar um pouco sobre o modo peculiar de ser no mundo boiadeiro, considerando sua estreita relação com estas diversas paisagens. No Pantanal, devido às extensas áreas de alagamento na planície, a Comitiviva siginifica muitas vezes, a única forma possível de se conduzir o gado. Para tal, optou-se por se construir uma interpretação fundamentada na abordagem cultural da paisagem, por meio da utilização da descrição contextualizada. São paisagens culturais pantaneiras.

Os boiadeiros possuem um diversificado sistema de símbolos significantes (linguagem, arte, mito, ritual), que contribui para autocontrole, comunicação e orientação das Comitivas. Isto se incorpora não só à prática desta atividade, mas entrelaça as diferentes concepções e percepções de sua existência como indivíduo e socialmente, reproduzindo sua cultura. Neste contexto, há um conhecimento tradicional que se desenvolve durante as longas viagens pelas estradas, originando um processo de adaptação e criação em resposta às diferentes condições do ambiente e que expressa uma forma única de contato com a natureza.

Para execução do ofício nas Comitivas de boiadeiros, não somente o conhecimento pelos locais onde atravessam é imprescindível, mas exige do viajante habilidade exímia no transporte do gado, para que este chegue saudável ao local de destino. Nas marchas com centenas de cabeças de gado enfrentam adversidades de acordo com a sazonalidade das estações (enchente, cheia, vazante e seca). No período da cheia não lhes falta água, ao contrário, o excesso desta significa uma preocupação pelo caminho, e já na seca a

\footnotetext{
${ }^{113}$ Cf. Bird Rose (2004) e Carlson (2000) como exemplos de autores da literatura sobre boiadeiros Australianos e norte-americanos, respectivamente.
} 
preocupação é oposta. Não só para o homem, mas também para os animais conduzidos o sofrimento pode ser maior de acordo com as extremas condições climáticas e sensações decorrentes desta ${ }^{114}$.

Além das técnicas necessárias para desempenho deste oficio, as Comitivas de boiadeiros possuem um conjunto de rituais cotidianos que contribuem para sua organização e costumam ser cumpridos. Estes estão imbuídos também de valores éticos, tal como pode ser observado nos pontos de parada, sobre as regras na cozinha para se servirem.

Tratando-se dos roteiros percorridos pelas Comitivas, observou-se que os boiadeiros se utilizam de mapas mentais transmitidos oralmente, que provêm do conhecimento vivido e compartilhado entre boiadeiros e moradores das fazendas. Por meio destes sistemas de comunicação constituem-se formas de leituras relacionadas, principalmente, à situações, objetos, configurações, o que compreendem os marcos referenciais nas paisagens. São elementos que revelam o significado de lugar, sendo mais frequente, aqueles relativos aos ambientes das fazendas e aos níveis de disponibilidade hídrica, de acordo com as estações sazonais. Deste modo, considera-se que a construção do modo de ser, de agir, de pensar está intimamente ligada à organização do espaço, ao sentido de lugar e à maneira como é percebida por quem é responsável por essa organização ou a experimenta. (CLAVAL, 2001).

Quando os boiadeiros discorrem sobre suas viagens costumam colocá-las como viagens no estradão ou viagem nesse mundão, o que traz a impressão de que o mundo dos boiadeiros é simbolizado pelo movimento, pois a estrada significa o seu mundo. Neste sentido, as Comitivas parecem ter sentido de liberdade, o que se confirma segundo relatos orais, que apontam que a vantagem do peão de estradão é não precisar ficar parado ou preso nas fazendas.

${ }^{114}$ Ver tabela 11, p. 146. 
Em ambas as situações, seja no movimento ou nos pontos de parada, as lembranças de imagens e paisagens estão conectadas às marcantes estações climáticas, principalmente a cheia e a seca, às fazendas, mas também aos rios, matas e outros elementos que se conectam. Por meio dos relatos analisados, parece que a estação da água simboliza a manifestação da vida latente, mas também um temível poder adormecido. Em certas condições deste ambiente percebe-se um sofrimento implícito dos boiadeiros nas viagens pelo estradão. Os sentimentos relacionados ao valor de intimidade crescem com as dificuldades das extremas condições climáticas e receios, medos pela existência de reais perigos. Nestes casos a habitação da casa evoca a sua moradia na cidade, sua família.

Então, é muito cansativo, e quanto mais dias passa, ô, O, mais você, ocê começa a achar uma falta de casa, você começa a viajar. Fica 20, 30 dias, então você começa a achar falta da casa. (...) Ah, sente, você sente falta, você acha falta da, da comidinha da mamãe, tipo, na época, que nem, teve uma época que eu era casado, você acha farta do carinho da muié, farta dos filho, é... (JUAREZ, 2007).

Portanto, quando se busca o sentido de casa $^{115}$ (BACHELARD, 19?-, p. 21) para os boiadeiros, percebe-se por meio dos relatos que há uma diferença entre o sentimento daqueles que são casados e os que são solteiros. Os primeiros têm seus desejos projetados ao retorno à casa da familia, como um sentimento que se almeja no término da Comitiva, já os mais jovens, ou solteiros, apesar de expressarem saudades de sua família, projetam o sentimento pela casa como aspirações e imaginações como conquistas futuras, tal como construir um lar.

Sofre, ah, é mais difícil, pra quem é casado é difícil já, e acostumô com a muié, o filho também, e pra quem é sorteiro, sorteiro num liga pra nada, num tem nada pra, só ele memo e fica mais tranquilo. (BARRIGA, 2009).

É neste ponto que se encontra um desejo manifestado por vários boiadeiros, o da casa sonhada ${ }^{116}$. Para alguns destes está no desejo de construir ou comprar uma casa para família ou que no futuro, ao aposentar-se possua uma casa para morar. Interessante que em nenhum momento estes boiadeiros mostraram aspirações em tornar-se proprietário de uma casa no

\footnotetext{
${ }^{115} \mathrm{O}$ que se remete ao espaço maternal, ao refúgio, principalmente no dizer do "espaço de intimidade, ou espaço de nossas solidões". (BACHELARD, 19?-: 21-43).

${ }^{116}$ Cf. BACHELARD (19?-), p. 58.
} 
campo, ser pecuarista, mas sim de ter uma casa na cidade. Isso também pode estar relacionado ao seu contexto histórico, econômico e social, pois dificilmente com o salário que recebem poderão, nos dias de hoje, adquirir uma fazenda no Pantanal. Até mesmo porque não costuma haver oferta de mercado para compra de pequenas propriedades (menos de 1.500 hectares) nesta região.

$\mathrm{Na}$ conversa com os boiadeiros mais jovens, nota-se um anseio constante em terminar a viagem, mudar de ofício. Como coloca Guimarães Rosa (2006:35), a impressão é de que durante as viagens, estes atravessam as "coisas" - e no meio da travessia não vêem - só estão entretidos na idéia dos lugares de saída e chegada. Têm a mentalidade voltada para o futuro, diferentemente dos mais velhos que apesar de sonharem com uma casa na cidade, parecem vivenciar o cotidiano e, atentam-se mais ao presente do que o futuro. A impressão é que "não têm pressa para chegar", pois há uma contemplação da vida no dia a dia.

Um das percepções desse estudo é alusivo as permanências, contradições e adaptações às mudanças econômicas e sociais, sendo um tema recorrente e pertinente a esta discussão. A inserção dos boiadeiros no universo agropecuário, o que representa a economia principal da região, está arraigada em uma política global de mercado, baseada na modernização capitalista. Esta é considerada por vários segmentos sociais como uma das atividades mais impactantes para o meio ambiente, e não obstante seja considerada no Pantanal, por Mourão et al (2000), como uma aptidão agroecológica, o gado é uma espécie exótica introduzida, que pode acarretar consequências, principalmente se considerarmos esta pressão econômica para o desenvolvimento e produção em grandes escalas comerciais. Assim, podem ser incluídas as Comitivas, que geram impactos durante as longas viagens pelo Pantanal, tal como o pisoteamento deixado pela boiada, quanto à disseminação de espécies exóticas nas fazendas pantaneiras. $^{117}$

\footnotetext{
${ }^{117}$ Já citadas no Cap. 03,pg. 121.
} 
Outra questão relevante relacionada ao contexto sobre mudanças sócioeconômicas é que apesar dos boiadeiros no passado serem considerados pobres comerciantes, normalmente, eram eles que compravam o gado e o conduziam. (RONDON, 1972). Souza (1975), em Tipos e Aspectos do Brasil ${ }^{118}$, descreveu o boiadeiro como o comerciante de gado, intermediário entre os fazendeiros criadores e invernistas ou recriador de gado, que comprava as reses com um ano e nas suas invernadas cria-as até os quatro, quando então são vendidas aos mercados consumidores. (IBGE, 1975, p. 457- 458). Porém, ainda neste período Rondon (1972, p. 98) já sinalizava que:

Os boiadeiros do presente são diferentes daqueles que se foram ou se afastaram da atividade pela avançada idade, agora viajam em avião, apartam os bovinos entregando-os aos Condutores, um novo tipo que se tornará típico num breve futuro.

Atualmente, estes ofícios de comercialização e transporte do gado são separados. O boiadeiro comprador/vendedor, tem maior poder aquisitivo e é o fazendeiro, já o boiadeiro que conduz a boiada (focado neste trabalho), não costuma ter posse alguma, a não ser uma pequena casa na cidade. Em nenhum momento foi relatado que os boiadeiros comercializassem gado ou tivessem alguma fazenda. A não ser o Condutor, que costuma ser o proprietário da tropa de burros de trabalho nas Comitivas e por vezes pode ter uma pequena propriedade rural e/ou alguma rês.

Segundo fontes orais, é raro o fazendeiro que ainda conduz gado em Comitivas, segundo fontes orais, quando isso acontece é porque querem economizar ou não têm dinheiro suficiente para contratar uma Comitiva. Nestes comentários percebe-se quando o pecuarista necessita conduzir o gado, ocorre uma perda status ${ }^{119}$. É evidente que há um contraste entre boiadeiros e pecuaristas, sendo que o primeiro ofício tem sido gradualmente desvalorizado e parte dos mesmos almeja abandonar a profissão.

118 SOUZA, E.C. de. O boiadeiro. In: IBGE. Tipos e aspectos do Brasil. Rio de Janeiro: IBGE, 1975. 10 ed.

119 Talvez a pressão pela lucratividade contribua para aumentar esta desigualdade social entre boiadeiros e pecuaristas. Cf. Bosi, Ecléa. Cultura e desenraizamento. In: Bosi (2003) também discorre sobre esta questão, mas no contexto do bóia-fria. 
Porque quem trabalha nesse ramo, se não for capataz, se não for alguém que tem um cargo ele só vai conseguir alguma coisinha ele fica 5 anos, seis anos na fazenda. Porque, hoje, dela sai dinheirinho, aí compra uma casinha também. Então ele nunca vai passar disso, de ter aquelas coisinhas básicas. Uma casa, uma televisão e só. Pensar, eu vou comprar um carro bom, porque o salário não ajuda. Porque quem pensa em comprar uma casa, um carro bão, esse serviço é muito difícil. (JUAREZ, 2007).

No caso deste entrevistado, assim como observado em outras situações, há casos de abandono deste ofício para trabalhar no crescente ramo do ecoturismo, justificando ser um trabalho mais rentável. Este desejo de abandono parece surgir através da representação marginal que exprime a vida dos boiadeiros e de tantos outros brasileiros, com a imposição de um modelo econômico e de conhecimento que não é o tradicional. A política que impera se exprime primeiramente em ter, não em ser, o que se difere substancialmente da promoção às diversas visões de diferentes grupos sociais, a qual poderia proporcionar uma diversidade cultural.

E é interessante observar que o isolamento do boiadeiro durante as viagens não se constitui como fator de alienamento. $\mathrm{O}$ uso do rádio e do celular (com antenas) ou mesmo a comunicação com as fazendas os mantém conectados aos acontecimentos da região e do mundo que trazem novas aspirações, mas no campo de aprendizado desta atividade, continuase observando, fazendo, imitando para se tornar um prático $^{120}$.

Quantos são os boiadeiros? Quantos eram no início do século? Estão desaparecendo diante da concorrência com transportes modernos? Já viveram condições mais favoráveis? Estas são difíceis perguntas para se responder. Apesar de o gado transportado passar por controle fiscal e mesmo considerando que uma parte seja clandestina, pode-se afirmar que há inúmeros dados estatísiticos, mas já quem o transporta vive despercebido. Há poucas pesquisas e dados sobre os mesmos.

\footnotetext{
${ }^{120}$ Prático é utilizado pelo peão para dizer daquele que é esperiente e possui habilidade em exercer o ofício. O antônimo de prático é orelha. A origem deste termo está relacionada à forma-de se marcar a rês, pois as rêses novas em uma fazenda, que não foram trabalhadas (vacinadas, vermifugadas) não possuem marca nenhuma. São orelhas.
} 
Apesar dos boiadeiros persistirem enquanto práticos a enfrentar adversidades e de dizerem que as Comitivas não deixarão de existir enquanto houver Pantanal que alague os próprios sucitam a problemática deste ofício relacionada à desvalorização, baixa remuneração e a dimunição do conhecimento se comparado as gerações anteriores.

Se antes as Comitivas faziam longos percursos, atualmente, com a facilidade de acesso dos caminhões boiadeiros às estradas de rodagem, estas viagens têm diminuído tanto em freqüência, como tempo de duração. Neste sentido, Albana $(1990,2000)$ afirma que estes tem contribuido para o desaparecimento de uma tradição que vem de séculos.

Mais num era o dinheiro que era mais fácil, era o serviço que tinha mais. Tinha mais boiada pra puxá e hoje em dia é o serviço que tá difícil, leva aí 10, 15 dias já embarca ela [em caminhão boiadeiro]. As veiz viajava 40, 50 dias, virava, tava com ôtro serviço na mão. Às vezes o Condutor nem entregava aquela boiada lá, já tava com outra boiada pêga já. Largava a tropa, lá naquele (...) daí você viajava 7, 8 meses de serviço, agora hoje em dia não, hoje em dia você fica 10, 15 dias parado, as veiz até 20 dia.. (BIGUÁ, 2009).

Nas últimas décadas, segundo várias fontes primárias de dados, a instalação de frigoríficos na região do Pantanal, como em Corumbá e Campo Grande permitiu que as fazendas da região passassem também a trabalhar com a engorda do gado, o que tem mudado tanto a forma de se criar o gado, quanto os roteiros, maneiras e técnicas. A modernização tecnológica dos transportes, como a implantação mais recentemente a construção de algumas rodovias, também tem influenciado a mudança de opção da condução desse rebanho. Evidencia-se, em determinadas situações, uma concorrência entre um sistema tradicional de transporte e o sistema rápido de transporte voltado para o capitalismo.

Portanto, para efeito deste estudo considera-se antigos e novos modelos de vida, tradição e modernidade, ou seja, escalas temporais que convivem em um permanente trânsito, muitas vezes automático, e que em certos momentos, podem significar tensões entre preceitos preservacionistas, conservacionistas e modificações da sociedade não apenas nos espaços físicos, mas também nas utilizações e representações das paisagens. 
Podemos assinalar que as paisagens culturais pantaneiras não são homogêneas e lineares e fazem parte de uma conjuntura histórica, econômica, social e cultural. Em cada lugar, um sentido particular está associado às palavras e às diferentes experiências ligadas a elas, "as sociedades são sempre realidades fragmentadas e diversificadas". (CLAVAL, 2001, p. 49). Neste sentido é possível compreender um pouco mais sobre a convivência e interação dos boiadeiros com outros modos de vida predominantes, assim como também investigar sobre as contradições que conjugam por estarem imersos nestas realidades.

As paisagens são reconstruídas constantemente, em novas bases, onde valores de um ou de outrem permanecem, enquanto outros são substituídos. Segundo Bosi (2003), sempre que uma inovação penetra a cultura popular, ela vem de algum modo traduzida e transposta para velhos padrões de percepção e sentimento já interiorizados e tornados como que uma segunda natureza. De resto, a condição material de sobrevivência das práticas populares é o seu enraizamento. No caso deste cenário, podemos observar que o intuito não é a valorização da cultura local, mas sim a expansão dos interesses econômicos da agroindústria.

Os boiadeiros, viajantes do tempo e do espaço, não estão isolados do mundo, estão integrados à sociedade e abertos a todo o tipo de mudança, tais quais, fazem parte do ser em sua própria existência, e também de suas criações. Compreender esse ir e vir de sujeitos que interagem no mundo e com o mundo, não significa negar sua legitimidade, mesmo para esse específico caso de estudo, onde os boiadeiros, considerados nômades, possuem uma constatne mobilidade espacial.

O ser humano não é ser qualquer Homem; é ser uma espécie particular de homem, e sem dúvida os homens diferem. Mesmo dentro da sociedade estas diferenças são reconhecidas. Há então que descer aos detalhes, para aprender corretamente o caráter essencial não apenas das várias culturas, mas tambem dos vários tipos de indivíduos dentre de cada cultura, se é que desejamos encontrar a humanidade face a face. (GEERTZ, 1989). 
Portanto, nesta pesquisa, procurou-se compreender o boiadeiro por meio da preocupação com o particular, o circustancial, o concreto, mas também organizada e dirigida em termos sobre o seu modo de ser, viver e compartilhar as paisagens, em termos de influência mútua sobre eles.

Como expõe Freire (1983), sobre a "Sociedade Brasileira em Transição", o conceito de relações da esfera puramente humana, guarda em si conotações de pluralidade, de transcendência, de criticidade, de consequiência e de temporalidade. Há uma pluralidade nas relações do homem com o mundo, na medida em que responde à ampla variedade dos seus desafios, em que não se esgota um tipo padronizado de resposta, e em que esta pluralidade não é só em face dos diferentes desafios que partem do seu contexto, mas em face de um mesmo desafio.

É possível então, construir uma conexão com o conceito antropogênico de Balée (1994) e Posey (2006), pois pode ser compreendido que o Pantanal tem sido manejado e interpretado constantemente, desde os Kayapos, Guató, Guaicurus, entre outras sociedades indígenas e até mesmo quando nos referimos à ocupação mais recente, cerca de 300 anos, quando foi iniciada a introdução do gado. Por ser uma região que agrega não só ecossistemas únicos, mas também economicamente ativa, principalmente pela pecuária, revela-se um contexto específico de sistema sócio político e econômico.

Com base em Balée (1998), Meneses (2002) e por meio da interpretação dos dados primários coletados nesta pesquisa, compreende-se que os boiadeiros, em sua especificidade cultural interagem ao longo do tempo com as paisagens pantaneiras Sul-Mato-Grossenses, podendo ser compreendidos como fenômenos totais. Sauer (1925, p. 59), diferentemente destes autores, apesar de considerar a relação paisagem e cultura, coloca que a força que modela está na cultura, "dentro dos amplos limites do meio físico da área há muitas escolhas possíveis para o homem”. Apesar de considerarmos a liberdade de escolha do homem, neste 
estudo, observou-se que a paisagem pantaneira, de certa forma, também o modela. Tal como exemplo, por meio das condições extremas da variação temporal dos níveis das águas.

Seria pretensioso e errôneo julgar em qual sentido está relação se mostra mais evidente ou determinar o quanto corresponde o peso de uma ou de outra. Portanto são considerados como processos interdependentes, o que vai de encontro a concepção de um outro autor, Ab' Saber (2004), quando completa que as paisagens são heranças que envolvem diversos processos e constituem-se em espaços totais.

As investigações sobre a paisagem e os segmentos sociais, evidenciam a importância de elementos identitários Meneses (2002) e podem contribuir para a discussão dos resultados (processo) de nossas ações, dos valores implicados nessas práticas e dos modos de sua atribuição, através do estudo do espaço vivido, que converge numa abordagem de cultura sem a qual não há paisagem (SANDEVILLE, 2005:5).

Isto deve incluir pesquisas sobre as populações tradicionais, o que significa abrir possibilidades para apreender diferentes formas de manejo e abrigar o conhecimento sobre práticas sociais distintas.

Today, when the practical consequences of the expansion of Western civilization take the form of a deep ecological crisis of planetary scales, science and scientists are challenged by a new and unprecedented demand. One of these is the necessity of evaluation, in ecological terms, the efficiency of rural or primary productive systems (agriculture, cattle rising, forestry and fishing) through the perspective of a new paradigm: sustainability. (TOLEDO, 1992, p. 5).

Nesse sentido, pode-se dizer que a crise ambiental atinge tanto a escala global quanto as mais ínfimas regiões e, ainda, o cotidiano de cada ser vivente. Não poderia, então, ser diferente, quanto ao repensar os modos e o agir de uma cultura para buscar avaliar princípios que, deste ou daquele possam servir para um futuro em que prescreva não só as gerações atuais, mas também possam permitir o estabelecimento das gerações vindouras.

Vários trabalhos atuais reconhecem a importância do conhecimento de populações tradicionais, tal como Diegues (2000), que recomenda a integração da visão dos cientistas 
naturais e do especialista local na co-pesquisa para o co-manejo. Porém, a ciência clássica, mesmo com seu reconhecido valor e avanços para humanidade, muitas vezes submete-se aos interesses econômicos, sendo aceita como forma hegemônica do conhecimento, excluindo por assim dizer, saberes não científicos (populares, tradicionais).

Bosi (2003) e Oliveira (2003) afirmam que há um pluralismo cultural no Brasil. Essa aceitação da pluralidade cultural deve vir não apenas da sociedade, mas deve ser promovida pelo Estado, a "diversidade de modos de ser, isto é, de existir, de fazer e de pensar, como opções tão legítimas quanto aquelas consideradas expressivas do brasileiro moderno, letrado (...)”. (OLIVEIRA, 2003, p. 192).

As percepções apresentadas nesta pesquisa podem ser subjetivas, efêmeras e particulares, mas não deixam de ser realidades humanas interpretadas. Entretanto, não basta referir-se a elas ou explicá-las é preciso vivê-la em sua imensidão ou ao menos a compartilha com aqueles que a experienciam. "O ser do homem é um ser não fixado. Toda expressão o desfixa”. (BACHELARD, 19?-, p-159).

Desta forma, imprimem-se no universo do boiadeiro diversas paisagens e imagens vividas, não necessariamente exatas, mas que tonalizam o ser interno. "Aqui, a criação se produz na linha sutil da frase, na vida efêmera de uma expressão. Mas esta expressão poética, embora não seja uma necessidade vital, é mesmo assim uma tonificação da vida. $\mathrm{O}$ dizer é um elemento do viver. São palavras vividas. A imagem poética é uma emergência da linguagem significante”. (Ibid., p.12) 


\section{CONSIDERAÇÕES FINAIS}

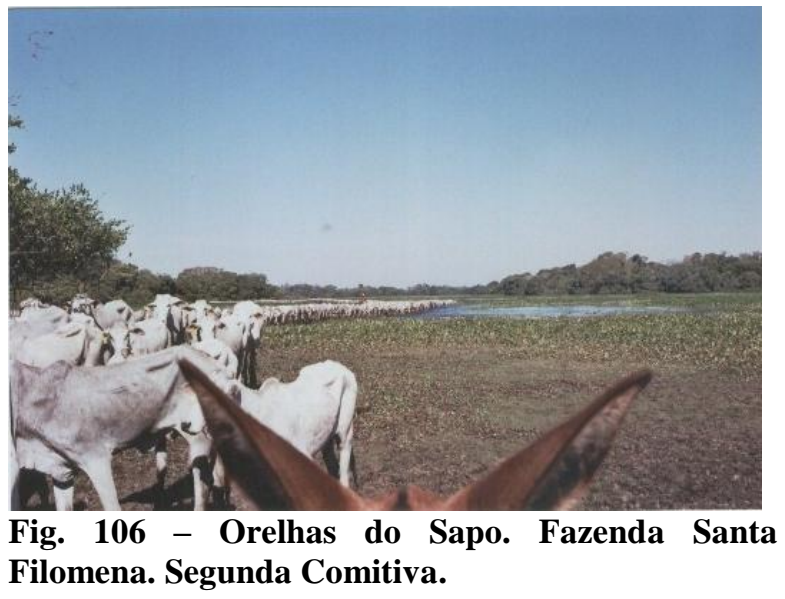

A paisagem se constituía, ainda, em um verde campo, mas que já anunciava sua seca pela poeira que se levantava na marcha de 1.008 cabeças de gado. Sapo, um burro muito inteligente, com suas orelhas enormes e atentas, parecia que compartilhava minha inquietação em compreender "tudo" sobre o modo de vida dos boiadeiros, no Pantanal. Claro, isto seria impossível! ${ }^{121}$ (Segunda Comitva - Anotações de viagem).

Esta pesquisa, por meio da interpretação de bibliografias e fontes primárias, organizou uma pequena compilação de dados sobre o modo de vida e a leitura da paisagem dos boiadeiros no Pantanal-MS, iniciando o debate sobre a permanência desta categoria de trabalhadores nas atuais atividades pecuárias.

A partir desta vivência, observando o trabalho que os boiadeiros realizam no transporte do gado de uma região a outra, foi possível notar a riqueza do conhecimento da natureza e de viver a importância em se vivenciar a paisagem pantaneira. Deste modo, é possível apontar uma percepção sobre a importância do valor cultural dos boiadeiros do Pantanal- MS.

Acredita-se que por meio dos procedimentos adotados (como deixá-los à vontade para falar), no sentido de buscar uma pesquisa preocupada com as percepções dos sujeitos, enfim, pela trajetória metodológica escolhida, mais como um caminho a se orientar do que um modelo a ser aplicado, foi possível revelar uma diferente perspectiva sobre o universo do boiadeiro.

Os acompanhamentos presenciais foram um importante instrumento de trabalho e infelizmente, por problemas de saúde da pesquisadora não foi possível participar de todas Comitivas previstas no ínicio da pesquisa. Para próximos interessados, esta é a principal

\footnotetext{
${ }^{121}$ Participação na terceira Comitiva de Boiadeiros, durante três dias, em Julho de 2007. Está Comitiva iniciouse no dia 10 de julho, devendo ter chegado ao destino final por volta do dia 11 de agosto.
} 
sugestão como forma de se obter outros dados sobre o tema. O Cozinheiro Biguá também apontou a mesma sugestão, colocando que seria muito importante que alguém que quisesse escrever sobre Comitivas, as acompanhasse do ínicio ao fim, para perceber esta realidade.

O que eu acho que devia ter, é que nem eu falei pra senhora assim, né. Acompanhasse, por exemplo, pegar um condutor que vai levá uma boiada para levar lá no Paiaguá, pra lá, né, aí você faz uma reportagem compreta, né. Pega aquele que tem 4 cargueiro, aí você faz a reportagem completa, aí que eu falo que você pega a realidade. Porque tem muita gente que pega assim, vai cortado, não companha do começo ao fim. (...) Eu, no meu dizer, para fazer uma reportagem completa, pra ficar boa memo tinha que ser do começo ao fim, porque alí você ta ali, junto. Junto com a turma, todo momento você ta junto com a turma. Tem o gravador, filma tudo, filma o dia inteiro, mas pegar esses, o melhor momento né. Aí, acho que fica um reportagem compreta.(BIGUÁ, 2009).

Uma dificuldade sentida neste trabalho foi a falta de proximidade ao campo de conhecimento da Antropologia, talvez por não ser um campo de formação da pesquisadora. Entretanto, as leituras antropológicas fornecerem subsídios para o que foi necessário.

No decorrer deste estudo, várias idéias surgiram como potenciais temas para outras dissertações e investigações e significam lacunas identificadas: dados sócioeconômicos (estatísticos) sobre o ofício do boiadeiro; acompanhamento presencial em outras Comitivas desde sua saída até o destino final; mapeamento das estradas boiadeiras; comparação dos modos de vida ou rupturas entre boiadeiros Norte - americanos (Montana/Texas), australianos (Sul) e brasileiros (Pantanal).

De qualquer forma, esta pesquisa representa apenas uma pequena parcela relacionada ao conhecimento dos boiadeiros, o que mostra quão riquíssimos são os relatos obtidos e a observação do trabalho das Comitivas. Espera-se que sirva como um impulso a maiores estudos, já que se identificou que o modo de vida dos boiadeiros tem se modificado e são poucos os estudos sobre o tema. 


\section{APÊNDICE}




\section{APÊNDICE A - Primeira comitiva}

\section{Comitiva}

Para mim, palavra forte, de muito significado, mas sem palavras para explicar.

Tradicional? Sem questão!

Vi ecologia... O tempo todo...

Mas como contá-la?

Trabalho duro, como todos os trabalhos. Porém, o mais interessante, engraçado, não foram os detalhes, mas sim encontrar a sabedoria.

A sabedoria da vida, que tanto as pessoas procuram na palavra ecologia.

A sabedoria em como realizar um trabalho, uma função como dizemos, um nicho ecológico.

Tão bem definido, tão bem executado.

Fenômenos como a contagem dos bois pelo Miranda, ou a força do Vô Alfredo de apenas 75 "aninhos".

E a gente escuta, a Comitiva está acabando, lê:

"Pantaneiro, um ser em extinção"

É triste, é a realidade, faz parte da transformação...

Mas e a sabedoria? E a ecologia? Quem diz o que é? Essa sabedoria é ciência? Mas quem sabe o que é ciência? Ciência da miséria, da natureza, do local ou mundial? Ciência ética, ou ciência por ciência?

No "mundo novo", me parece, que trabalho braçal deve se fazer quem quer-mas e quem não quer?

A desigualdade do Brasil é realidade latente, presente, todo o tempo. Porque não há educação, não há diálogo, não há civilidade.

Não há escolha.

E o filósofo diz, o homem é condenado a ser livre

É por isso que o pantaneiro é um homem tão feliz.

(Texto escrito após participação na primeira Comitiva, em abril de 2004.) 


\section{APÊNDICE B - Mapas desenhados}

\section{MAPA DA ENTREVISTA I}

Roteiro de Comitiva - Juarez
\pm 10 marchs; $14-17$ léguas

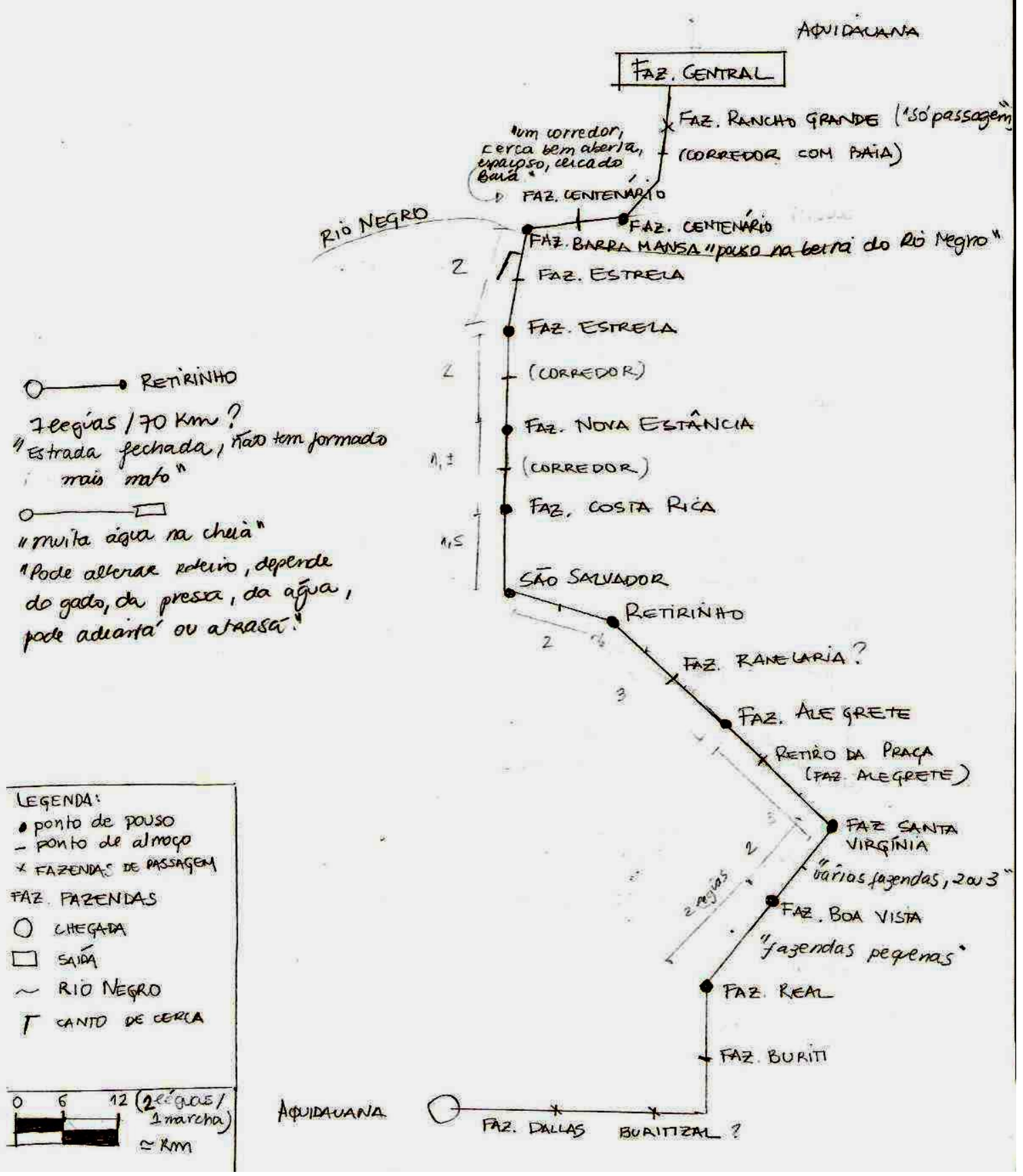


MAPAS $^{122}$ - Acompanhamento presencial de Comitivas.

Mara 2 o comitiva (Nossa senhora do Carmo)

Faz. Alvorada 'a

Faz. Nossa SRa. do Carmo

3 MARCHAS/70 $\mathrm{km}$

(300 BEzERRAR)

\section{LEGENDA:}

WH ESTRADA FÉRREA - AERRO

X POSTO FLORESTAL ב ASEALTO

O SAIGA / chegada

Sub-regilotes do pananar $\triangle$ MORRO

- PONTO de POUSO

- roteiro

- ponto de almoqo

Imario

حAREA INUNDACÁT

:P(E PARATUDAL

*

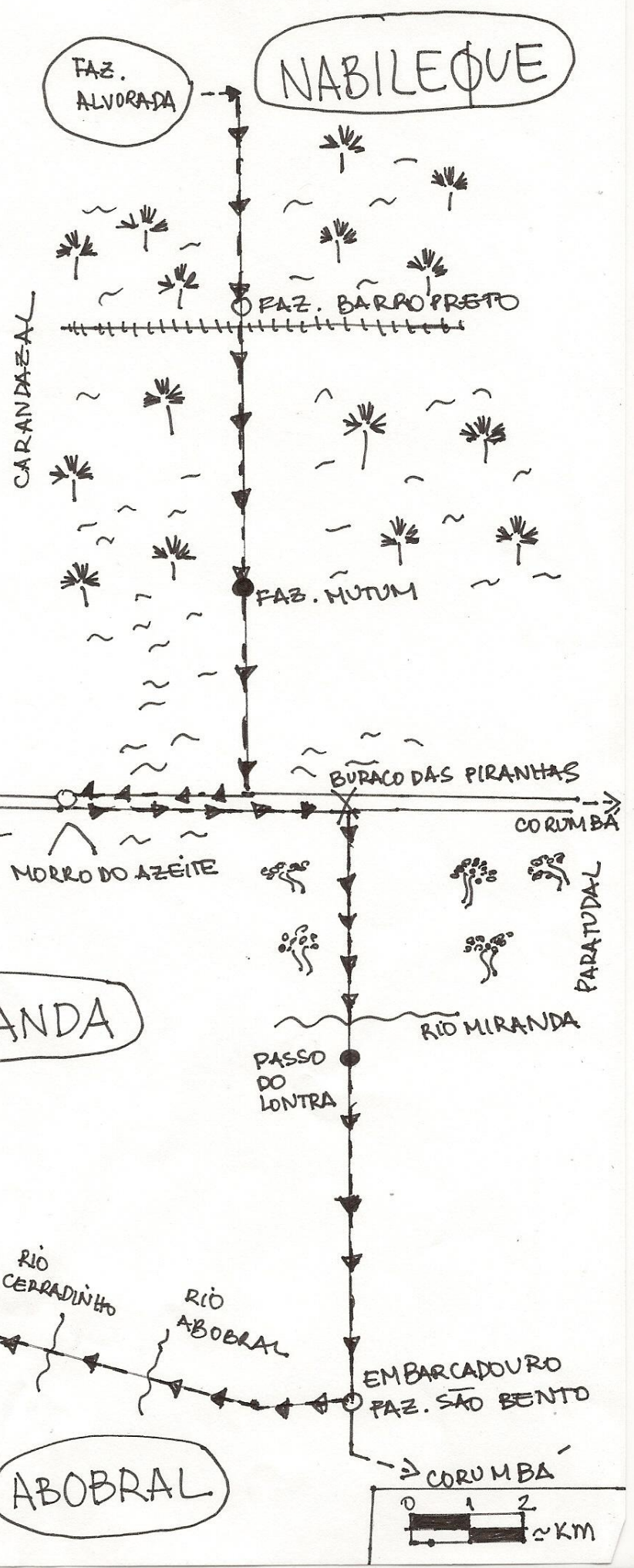

${ }^{122}$ Não foi possível desenhar o mapa da primeira Comitiva, pois naquele momento não havia intuito de desenvolver esta pesquisa. 
Mapa 3e comitiva (Nove de Ouro)

Faz. Nossa sra. docarno. i faz. sto. onofre

3 MARCHAS $/ \pm 38 \mathrm{~km}$

( 1.008 VACAS)

NHECOLANDIA

FAZ. STO

ONOFRE

FAZ.

Buriti

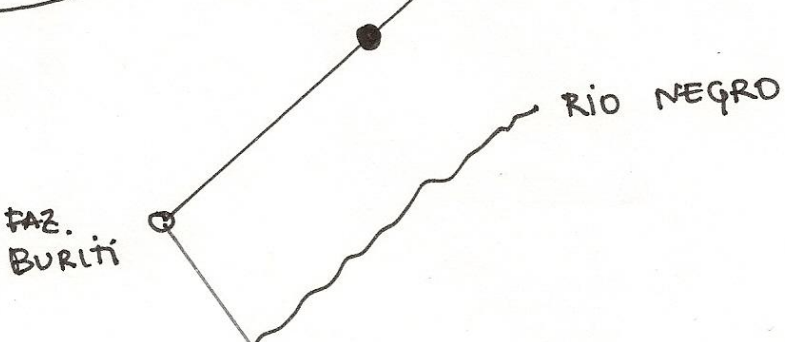

- $\sim-1$

BREJO-

C -

ABOBRA
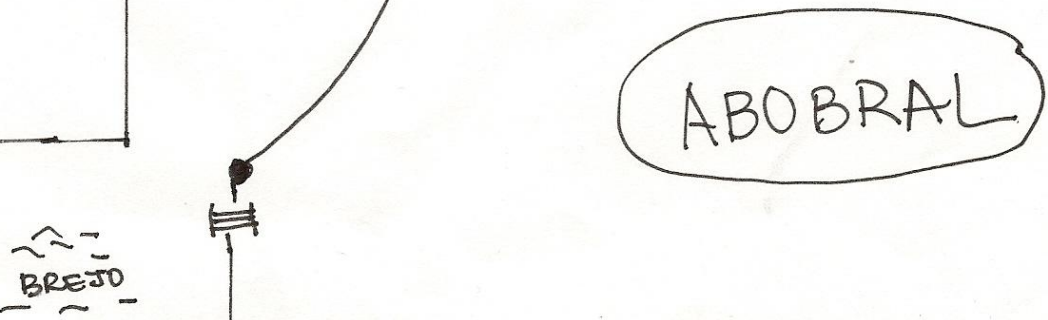

FAZ

faz. SÁ carlos

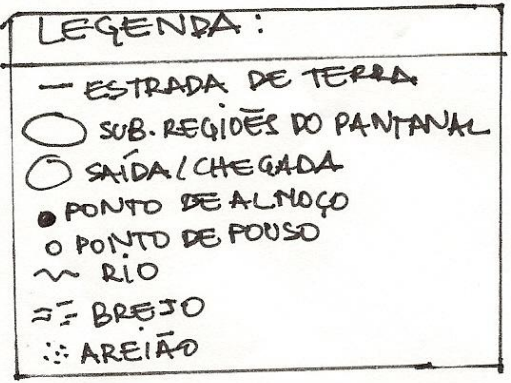

DIVISA ENTRE PaZENDAS

- BREJO-

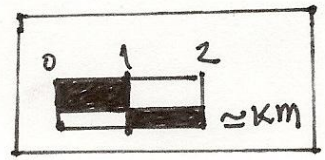




\section{APÊNDICE C- Entrevistas}

\section{Roteiro das Entrevistas:}

Dados pessoais: nome, idade, onde nasceu, família, escolaridade, religião.

1) Gostaria de saber sobre sua historia de vida e como começou o trabalho nas Comitivas. $\mathrm{O}$ senhor pode me contar um pouco?

2) Quando começou a viajar, como aprendeu? Onde?

3) Como que é seu dia a dia?

4) Essa Comitiva vai de onde pra onde? Quantas cabeças?

5) O senhor costuma levar gado de onde pra onde? Quanto tempo? Qual a distância?

6) O que é Comitiva de fazenda? Comitiva de estradão?

7) E o gado quando sai no primeiro dia, assim na Comitiva? É difícil de conduzir no começo?

8) A forma pra ir amansando, o que é importante?

9) E tem um gado que você acha que é mais difícil de trabalhar, que é mais difícil de levar? Tem algum que é mais, ou é tudo igual, não tem diferença?

10) O que é muito importante levar na Comitiva? E o arreador, o laço, e o berrante?

11) Chama-se também vaqueiro, peão, campeiro ou boiadeiro? Qual a diferença? Acha mais difícil o trabalho na fazenda ou na estrada?

12) Na Comitiva, quem tem que saber melhor o caminho?

13) De todas as profissões qual que você acha mais difícil, já? O senhor pode me contar um pouco sobre cada função? Comissario, cuca? Culateiro, Condutor, Meeiro?

14) Às vezes vai de carro, trator? Quando e porque vai de carro ou trator?

15) E como é que é o pessoal de Comitiva? Como é a relação? Como é que é?

16) O senhor sente por ficar longe da família? O pessoal da Comitiva reclama também?

17) É dificil de trabalhar com seu pessoal? Tem muito problema? Por que acha que é assim?

18) Vamos supor que vai sair uma comitiva, entao um fazendeiro ou corretor liga para o senhor? Como é que funciona?

19) Quanto vale cada marcha? E a diaria do boiadeiro? Cozinheiro ganha mais?

20) Antes boiadeiro era comprador de gado?

21) Quais vantagens e desvantagem em levar gado comitiviva. Que tipo de gado leva em caminhão e que tipo leva-se à pé?

22) As Comitivas as vezes são muitos dias? E chega, já sai pra outra?

23) O senhor deve conhecer bem os caminhos, então poderia me falar um roteiro? Por exemplo, o dessa viagem. Ou o senhor pode me dizer um caminho, roteiro que conhece bem e que lembra mais detalhes, como se passa por corixo, como que são as fazendas...

24) Há diferença em fazer Comitiva na cheia e na seca? Há dificuldade?

25) Que tipo de dificuldade? Em que lugares?

26) E corredor? Calefão? Estrada cascalho, asfalto? Há portões de fazenda fechados? Sempre pagou-se pelos pouso?

27) O que é ser bom pra ser boiadeiro, pra boiadeá, o que precisa se bom, no dia a dia, o que que precisa saber?

28) Com algumas pessoas que eu conversei, eles não querem mais trabalhar como boiadeiro, porque será isso?

29) Tem alguma coisa que eu não perguntei que o senhor acha interessante falar?

30) Tem algum causo, alguma coisa curiosa que o senhor acha diferente, interessante, curioso, e eu não perguntei? Historia engraçada?

31) Perguntar sobre o causo da fazenda Capão Verde, perto da Fazenda Pequi, sobre um galpão assombrado. 


\section{ENTREVISTA I}

\section{Juarez Rodrigues da Silva}

- Entrevista realizada em Julho de 2007, no Refúgio Ecológico Caiman, Miranda-MS.

- Juarez tem experiência com o ofício de boiadeiro. Em Julho de 2007 era funcionário guia de campo do Refúgio Ecológico Caiman. Logo após, trabalhou cerca de dois anos como motorista de mototáxi e viajou em duas Comitivas da Fazenda São Salvador, com o Condutor Carmo. Ambas foram viagens curtas, com cerca de 15 dias. Em julho de 2009 voltou a trabalhar no R.E. Caiman como guia de campo.

- Em julho de 2009 esta entrevista foi relida para o interlocutor, com apontamento de dúvidas e outras interrogações da pesquisadora. Desta vez, o encontro ocorreu na casa da Sueli, esposa de Juarez, que mora na área urbana do município de Miranda-MS. A mesma também contribuiu nesta segunda conversa, sendo importante dizer que tanto ela como sua família viveram muitos anos no Refúgio Ecológico Caiman.

- Parte desta segunda entrevista está registrada entre parênteses junto à entrevista (não foi gravada, apenas registrada em anotações sobre a primeira entrevista). Uma outra parte foi gravada e segue no item Entrevista I (b).

- Idade? 42 anos

- Escolaridade? $5^{\circ}$ série

- Religião? Católico

- Casado? Separado e agora amigado com Sueli

- Filhos? 5 mulheres (1 filha com Sueli)

- Onde nasceu, sempre morou no pantanal? Aquidauana (Fazenda São José, mas foi criado na Fazenda Buriti)

- É pantaneiro? Sim, legítimo.

- Pai e mãe de onde? Mãe é de Ponta Porã e Pai é de Cuiabá

- Com quem aprendeu a trabalhar? Pai? O pai era capataz, aprendeu serviço de fazenda, também fazia viagem, mas não viajou com pai. (começou a viajar com quem?)

- Onde começou a trabalhar? Fazenda Buriti

- Qual era a posição na Comitiva? Culatra, Fiador

- Perguntar como é que era, quando você fazia, na época, quanto tempo faz, é... que você fazia Comitiva, como é que era a vida, o dia a dia?

- Você quer saber como é que funciona, como é que é, é... um peão de Comitiva, que eles falam.

- É, mas como é que era a sua experiência também, como é que era a sua vida? Porque você começou a fazer há quanto? Faz tempo já, que você fazia?

- É, quanto tempo... Eu comecei a fazer, tinha a média de 19 anos. Eu comecei a viajar no estradão, você fala viajá no estradão, né. ${ }^{123}$ Você fala: vou fazer uma viajem, ou uma perigosa, é tudo a mesma coisa (...) Uma perigosa é um tipo duma viajem também, né. É um palavreado do peão, né. O cara fala, vamo faze uma pitoca: É uma viajem curta. Você fala,

\footnotetext{
${ }^{123}$ Os trechos grifados na entrevista foram utizados nos capítulos desta pesquisa.
} 
vamo faze uma pitoca, é uma viajem de 20 dias, 15, de 10 . Uma pitoca [viagem de 5, 10, 15 dias, menos de um mês ]. Você fala, onde ocê vai? Vou fazer uma pitoquinha aí, então o peão já entende que é uma viagem curta.

- Eu comecei numa média de 18 pra 19 anos, só que eu nasci e criei em fazenda. Então, eu já tinha trabalhado muito em fazenda, dentro da fazenda, no campo, mas dentro da fazenda, né. Experiência de viajá pra fora, assim, eu não tinha, e eu era muito miúdo, não sabia. Quando eu via meus companheiro que chegavam, o que me mais me chamou a atenção foi no sentido de trabalho, porque quando eles chegavam, eles faziam uma viagem de uns 70 dias, eles chegavam, chegavam tudo bonado, todo mundo chegava com dinheiro, né, eles faziam aquela farra de cervejada e (...), (e fazê farra com mulheres, como por exemplo, se tivesse passando por Miranda, ou pequeno patrimônio-povoado, gasta mais ou menos $30 \%$ com mulherada), aquela coisa... Eu falava, esse negócio deve ser muito bom, né? Essa turma chega com bastante dinheiro, chega tudo animado, mas pelo contrário viu? Muito cansativo, é, muito cutoso (custoso) pra pessoa que não tá acostumada, porque pra começar você levanta numa média de 3 horas da manhã, você acorda, aí você tem todo um trabalho antes de você encilhar teu animal, você tem todo um trabalho, no que você ta dormindo ali, você tem que recolher tudo, colocá tudo bem arrumadinho dentro do dobro e entregar pro Cozinheiro bem arrumadinho, né. Aí, cedo você não come, você só toma um café, antes de clareá o dia você toma um café, tipo 5 horas, já ta querendo clarear, você já tomou seu café e já ta com seu buçal na mão pra você pegar seu animal.

- Só o café?

- Só o café. Ai o cara toca a tropa, oo.. o peão tropeiro. cada dia é dia dum, (entre Meeiros, Fiadores e Ponteiro), entendeu, cada dia um toca a tropa. Aí você, o cara vem, o cara vai tocar a tropa, o cara tem que dar água pra tropa antes de trazer a tropa pra você encilhar. Tem veiz o açude é tipo, $2 \mathrm{~km}, 3 \mathrm{~km}$, longe da onde tá a turma acampado. Aí ele tem que levar lá a tropa a pé, dá água e trazer, porque a tropa costuma tomar água só quando leva. Aí você encilha, aí você sai. [A ordem para tocar a tropa é sempre $1^{\circ}$ Ponteiro, $2^{\circ}$ Fiador, $3^{\circ}$ Meeiro - Meeiro é igual a Culatra, $4^{\circ}$ Culateiro].

- Como que você sabe o caminho que você vai fazer?

- O caminho que você vai fazer é o seguinte, você já tem uma, quando você vai sair, você já tem uma rota desde antes você de você sair com a boiada, você ir lá pegar a boiada. Porque é assim, o cara fala, vamo fazê uma viagem. Ah, então vamo. Onde nós vamo pegá? Ah, nós vamo pegá lá na fazenda, ah, vamo supor, na Sebastião Grande, fica lá do lado de lá do Taquari. Tá, aí você...

- Taquari é o rio?

- Taquari é o rio. Aí você já, aí você como é um peão viajado, você já, tem muitos que já conhece tudinho esses pouso. Aí o cara fala, nóis vamo lá pelo Taquari, (Faz desenho com graveto na areia) nóis vamo sair aqui, nóis vamo entrar aqui. SantaTerezinha, Santa Terezinha nóis vamo na Livramento, Livramento

- Que que é Livramento?

- Livramento é uma fazenda, outra fazenda.

- Outra, tá...

- Aí do Livramento nóis vai na Juazeiro, do Juazeiro nóis vai na São José, da São José nóis vai na São Sebastiãozinho, da Sebastiãozinho nóis vai na Novo Horizonte, a gente pousa no rio, a gente atravessa, daí a gente tem um roteiro traçado. Quando a gente vem, quando a 
gente vai vir, o Cozinheiro já sabe. Por exemplo, [faz desenho com graveto na areia] nóis tamo aqui na São Sebastião. Aí a gente tem que vim aqui, vamo fazê, vamos supor, na Novo Horizonte, onde a gente tem que pousar, dá $12 \mathrm{~km} 1$ marcha. 1 légua são $6 \mathrm{~km}$. 1 marcha varia da distância de uma fazenda para outra, podendo ser até $20 \mathrm{~km}$. Normal é de 10 a 12 $\mathrm{km}$. Normalmente, na média de 5 a $6 \mathrm{~km}$, na metade da caminhada, o Cozinheiro, tem uma água boa por ali, uma água boa que a gente chama é um açude. Quando você acha um açude de água branca, de água limpa, nossa! É muito bom! Aí o Cozinheiro sai de lá, com os burro, com as carga, a bruaca, com tudo a traia e pára aqui. Aqui ele desencilha e faz o almoço (pára pro almoço) aqui por causa da água, porque a água serve pra, pra ele usá na cozinha e pra você usá pra tomá. Tudo ali. Entendeu, aí ele fala, vamo pousa lá em tal lugar. Daí ele sai e pousa naquele lugar.

O caminho que você vai fazer é o seguinte, você já tem uma, quando você vai sair, você já tem uma rota desde antes você de você sair com a boiada, você ir lá pegar a boiada. Porque é assim, o cara fala, vamo fazê uma viagem. Ah, então vamo. Onde nós vamo pegá?

\section{- E se não acha um açude?}

- Provavelmente, sempre tem. Sempre tem, porque quando não, não, tem, você, quando não tem com 5, $6 \mathrm{~km}$, você aumenta pra 8, 9, você tem que ir aonde tem um, entendeu?

- Um exemplo: Nós vamos sair daqui, nós vamos lá no São Domingos, com, com a Comitiva. Aí a Comitiva, o Cozinheiro fala assim, nós vamos almoçar lá no Retiro Novo, né, nós vamo almoçar lá no Retiro Novo, daí, o Cozinheiro vai chegar lá no Retiro Novo vai desencilhar os burro, dali perto da onde tem um água. Por exemplo: Não tem aquele açude na beira do mata burro, ali chegando? Então, desencilha ali, que ali serve pra dá água pra tropa, chega, pra tudo, então assim que a gente faz, a gente ter ? um roteiro. Então cada dia que ocê pousa num lugar, ôô... já é, o Cozinheiro já conversa com o Condutor, que é o capataz da Comitiva, né. Ele fala, vamo pousar lá em tal lugar. Nóis vamo por aqui. Tem vários lugares pra você ir, então nóis vamo por aqui, nóis vamo fazer essa rota. Nóis vamo pousa lá na São Sebastião

- Mas aí, como? Porque que ele fala, vai fazer essa rota, ou vai fazer aquela, cada uma?

- É, é porque depende aonde a gente, por onde a gente quer sair, as veiz, talvez, a gente quer cruzar um lugar que tem menas água, mas é mais longe o caminho, dá uma volta desviada de muita água, mas é mais longo o caminho, a gente anda mais no seco, mais anda mais dia, coisa que eu quero falar, nós vamo pega dois, três dias de água, só, vamo por aqui, (desenhando na areia) a gente vai pegar pouca água, a gente vai pegar dois, três dias só de água, a gente vai ganhar aqui, no mínimo, seis dia, vamo supor, fazê uma, encurtá grande a viagem. E talvez éé... por exemplo, o cara tem que, as veiz ocê sai com uma Comitiva, ocê quer passar num lugar, tem um gado seu, que ocê numa outra vez você, cuma boiada, você deixou, perdeu uns bois lá, o boi ta ali, ocê sabe que ta ali, então você passa por ali pra enlotar... uma boiada.

- Então muda o caminho, na época da cheia e da seca também? Às vezes vai estar mais...

- Isso, na época da seca, na época da cheia você muda pra você pegar menas água, e na época da seca, você muda pra achar água. Você tem veiz que tem seca que você anda dois dias você não acha, não encontra água, então não tem como você ir por ali. Aí você é obrigado a ir por outra fazenda, que você sabe que tem açude, feito com máquina ou alguma coisa assim, que dá pra você dar água pro gado, e você tê água pro gasto. É assim que funciona.

- E como que é a dificuldade na cheia e na seca? As diferenças? 
- A diferença na seca é que você passa, é você pega muita poeira, na estrada, porque, chega branco de poeira é, no almoço, ou no, pouso. E na cheia, é, você sofre muito pra você chegá no pouso, quando você chega no pouso, principalmente, porque você chega todo molhado, as veiz sua traia ta molhada, você ta molhado, e quando ta chov... e normalmente, na cheia, chove, e quando chove, não importa se ta chovendo, se não tá chovendo, você chega, você tem que desincilhar, você tem que montar o teu acampamento, tanto faz na chuva ou não. Aí tem todo um processo que você tem que chega, abri num machado, abri numa faca, numa pazinha com cabo curto, um machadinho com cabo curto, que carrega, né? Aí você pega e vai, faiz um buraco e mede a distância que dá pra puxá duma rede numa árvore, aqui, (mostra desenhando na areia), aí você faz um buraquinho, ali com uma pá, você vai lá pega um machado e corta um pau, finca ali, ali você arma a sua rede, arma a sua torda, que é uma lona de 4x3, ou depende o gosto do cara, o tamanho, né. Aí você tem que por suas coisas tudo ali embaixo daquela lona, sua traia de arreio, tudo ali, pra você se proteger só dali. Pra você tomou por base normalmente você vai passar a maior parte do tempo molhado, você vai dormir mal, vai chegar molhado e sair molhado, porque normalmente, quando tem (...) assim, você chega com chuva e sai com chuva.

- Você não tem esse negócio de falar, vamos esperar passar a chuva, você pega pra encilhar na chuva mesmo, você tem que ter uma regra, é igual um quartel. Vamo sair, tem que sair, e é cansativo, porque, por exemplo, num almoço, conforme a distância que o Cozinheiro acha a água, e é umas das dificuldades da seca, o almoço fica muito prolongado, chega tarde, você chega meio dia e meio, às vezes uma hora no almoço, aí você tá lá entre seis, você tira o buçal, os três tira o buçal e dá pra três ir almoçar, eles vão, troca de animal, pega o seu, larga amarrado já lá e almoça. Isso tudo com tipo, 15 minutos, o cara não senta, pra almoçar, não tem banco, num tem nada. Num tem sesteada, num tem nada. Aí ele vem, fica no teu lugar cuidando o gado e aí você vai almoçar. Você acaba de almoçar num tem nada, nem pra tereré você para. É procê tomá tereré andando.

- Êhh! Áhh rapaiz! (tocando o cavalo)

- Então, é muito cansativo, e quanto mais dias passa, ô, $\mathrm{O}$, mais você, ocê começa a achar uma falta de casa, você começa a viajar. Fica 20, 30 dias, então você começa a achar falta da casa.

\section{- Você sentia falta?}

- Ah, sente, você sente falta, você acha falta da, da comidinha da mamãe, tipo, na época, que nem, teve uma época que eu era casado, você acha farta do carinho da muié, farta dos filho, é... e tudo recompensa, nas veiz, na chegada, porque normalmente são tudo mundo, são reunido, né. Esses peão que a gente fala que viaja junto, é muito unido, né, chegam, normalmente eles arrumam um jeito de tomar uma cerveja junto ou comê uma carne junto, ocê entendeu. E o cara que viaja no estradão direto, tem tipo 3 dia, 4 dia, 5 dia de folga só. Ele chega, aí, conforme tá bom de viagem, ele chega hoje, descansa hoje e amanhã, noutro dia tem que sair de novo com outra Comitiva, porque ele não pode ficar parado, porque se ele perdê aquela viagem que vai sair, depois de dois dias que ele chega, aí pode demorar 20 dias pra ele sair. Se ele tem família, ele passa necessidade, então ele tem que sair. Então talvez dentro de um ano, tem veiz dentro de um ano, ocê fica 20 dia, 15 dias na casa só, o resto tem que sair.

- E na época da seca também à noite, tem o problema do frio, também? Ou não, não tanto?

- Tem o problema do frio, tem, tem, é... Principalmente no frio também, na época do mês de maio, junho, julho, agosto, venta muito, ocê só dorme em rede, então é muito frio. Coberta, ocê não pode levar uma coberta muito grande também. Tudo que ocê vai precisar, ocê tem que carregar só num dobro. Roupa, coberta, é pasta de dente, sabonete, o que ocê quisé usá. 
- Ninguém leva dois dobro?

- Às vezes leva, mas é...

- Você vai ficar muitos dias, né?

- Às vezes leva, quando é numa viagem muito grande, mas é tipo assim, um dobro e uma coisinha miúda, o cara põe separada ali, arguma coisinha ou então um dobro grande, mas é...

- Vou ficar muitos dias, né.

- Às vezes leva, quando é numa viagem muito grande, mas é tipo assim, um dobro e uma coisinha miúda, o cara põe separada ali, arguma coisinha, ou então um dobro grande, mas é...

- Tudo bem organizado...

- É... Porque é tudo nos burro, né, senão pesa muito. O cara as veiz ele fica uma semana com uma roupa. É só que ele chega, ele passa água, uma água na camisa dele só, né? Ele vai tomá banho, ele já leva a camisa dele, passa água, torce, estende, amanhece seca, na época principalmente da, na época da seca, né, ? entra, ?, amanhece seca.

- Normalmente ele usa bermuda, calça de couro então, toma muito pouco espaço no dobro, porque ele só usa, ele leva 4 bermuda, ele faz uma viagem 40 dias com 4 bermuda. Também quando chega, normalmente não presta mais. Então ocê pega bermu..., essas calça velha, corta, faz bermuda e leva. Aí você usa uma semana, quando daí um pouco pra ocê passá uma semana pra ocê passá. Quando não dá, quando ocê chega, ocê já, já chega fora, assim é que é. Mas é cansativo.

- E eu estou pensando aqui, das fazendas. Porque você falou que sabe o caminho pelas fazendas, mas por exemplo, se eu fosse fazer esse caminho, mesmo sabendo o nome das fazendas, eu não iria achar, porque nem, muitas pessoas tem no meio desse caminho para perguntar, onde é que é a fazenda tal, por exemplo. Então como que é que vocês se acham nesse caminho?

- Pois é, um exemplo, é...vou te mostrar um exemplo, aqui, que aqui dentro, pra você entender, vamo vê se tem algum lugar aqui, igual é nessas estrada por aí. O que acontece muito hoje em dia, a maior parte, antes não, antigamente, logo quando eu comecei a viajar, não existia isso. Então você ia pelo campo, só que é... antes...

- Em que época isso?

- Isso aí em 90, 93,93. Então você ia no campo, aí tem aquelas estradinha que só a batida aqui, entendeu? Tem uma estradinha...

- Ah... tem uma batida...

- É, não é cascalhada, não é nada, só aquela bitola, só aquela bitola. Um exemplo aqui tem exemplo assim.

- Ah, ta, a gente vai para o Carandazal, por exemplo, tem uma...

- Tipo, você vai para o Carandazal, é tem uma bitola ali, não é cascalhada, ou tipo aqui, você vai entrar aqui nesse formado, num tem essa estradinha aí, olha, uma bitolinha? Cê vai, então. Só que do lado aqui não tem formado, não tem nada, na maior parte, só que você não vai com o gado aqui na estrada. Então, o cara fica tão viajado que ele já sabe, então ele vai aqui (desenhando na areia), faiz a curva aqui, vamos supor que saia aqui a estrada, né. Então ele faz toda essa curva aqui. 
- O que que o peão da Comitiva faz? O Ponteiro faz? Que é o cara da frente que leva o gado na direção que ele quer. Daqui ele corta aqui, entendeu ó (desenhando na areia). Ele corta aqui, que aqui ele vai dando o pasto, o gado vai comendo. Aí no momento que de tanto ele passar ali, ele sabe que bem ali tem um açude. É o único açude que tem pra ele dar água pro gado. Só que o que ele faz? Ele faz esse caminho, vai lá no açude, pro gado tomar água, aí de lá ele vai sair aqui, ele vai cair na estrada lá na frente. Nunca ele anda na estrada, porque ele tem que dá, ele tem que ir dando pasto pro gado.

- E essa estrada é de passar carro, trator?

- Isso, essa estrada é aonde leva os veículos de uma fazenda na outra, entendeu?

- Mas tem vários lugares que não tem nem essa?

- Vô falá, olha, é muito difícil. É muito difícil, ocê tem essas estradinha de bitolinha assim, ocê tem ela em toda parte do Pantanal, ocê tem. Que sai duma fazenda, que vai na outra. Tem, tem, tem Ponteiro, que ele é tão viajado, tão conhecido, que é tão conhecido, ? que ele só olha e fala, vamo entra aqui, vamo entrá bem aqui, ir reto aqui, ó. Ce já sabe que essa estrada sai aqui, mas primeiro ela vai dá volta, vai sair lá. Então a gente já corta um atalho aqui, entendeu. A gente corta um atalho aqui, então assim que é a lida...

- (Cavalos perto, J toca os cavalos)

- ehhhh

- Eles são curioso, ne? É que tem um saco de ração ali...

- A pior época é a época da chuva, viu, Olivia, a pior época é a época da chuva. Nossa você não sabe o tanto que é ruim, é chato, você chegar num pouso, molhado, você tem que mexer com tudo suas coisas molhadas, sua traía molha, acaba molhando, cê as veiz num dá tempo de você. Você tem que desce do seu animal, quando você chega num pouso, tá chovendo, você não desencilha o teu cavalo, se tive chovendo. Você joga a capa nele, você joga a capa, aí você vai, vê se tem algum lugar de armar a sua rede, aí você vai, arma a sua barraca primeiro, daí que você vai armar a tua rede, tua rede, aí você vai lá desencilhar pra você já por sua tralha lá embaixo pra não molhar, porque senão não tem onde você por, então é...

- E pra comer também, né?

- É, acontece muitas veiz de você ficar com fome. Que nem um caso, você tava perguntando, como é que a pessoa sabe? É, tem muitos Cozinheiro que se perde, depois tem uma estradinha muito apagada, êhh, êhh, ô rapaz (o cavalo novamente) e o Condutor confia nele, de explicar pra ele, olha eu vou te explicar como é que você vai lá no pouso. Eu vou te explicar pra você saber como é que vai sair lá no pouso, então ta, então ta bom. Ó, você entra aqui, pega, bem aqui assim, tem um canto de cerca, você vai entra aqui, aqui tem um canto de cerca, naquele canto de cerca você pega pra direita, aí você anda tipo uns mil metros, que você vai enxergar uma campina aqui.

- O que que é campina?

- Campina é um lugar êita (cavalo de novo) onde ocê sai do mato, que quando ocê sai duma estradinha fechada, ocê sai num limpo, assim, um limpo pequeno. É uma campina. Um limpo se deixá cresce, é só mato de novo. Aí chegando naquela campina, você entra...

- Mas e essa campina, é natural ou é de pasto? 
- É natural, aí você entra no costado daquela campina assim, ó, ocê vai pegá uma estradinha apagadinha, e você segue nela. Como muitas veiz acontece deles faze e tentá fazê isso, em veiz dele pegá o lado certo ele pega o lado errado, aí ele perde, aí ele perdendo a hora de almoço, já foi, o almoço seu já era, aí é só a janta.

- Aí segundo nóis chegar com o gado, lá na onde o Condutor marcou pra ele ir, ele não tá, que que a gente faiz? Só troca de animal e, segue em frente. Troca de animal e segue em frente, cê num pára pro almoço, ocê num tem nada.

- E como que ele vai se achar?

- Aí, não, daí o Cozinheiro se vira, ele vê que ta perdido, aí ele volta, ele amarra os burro dele.

- (Espantando cavalos, Juarez é responsável pela tropa)

- Outra coisa que aconteceu comigo, ocê xinga, ocê estraguéja (esbraveja), ocê fica pra morrê! É num é só pra (...). Então nessas Comitivas sempre tem uns burros safados, uns burros que senta com buçal, senta no buçal e acaba arrebentando teu cabo, sai correndo com tua traia, sabe, aí sua trai cai até a barriga dele, e acaba com ela e péin, rebenta tudo, cai no chão, aí ocê tem aquele trabalho de tá, correndo atrás, pegando, arrumando tua traia, ocê chega assim, sua traia tá tudo arrebentado, rasga seu baixeiro, aí cê já fala, puta merda, essa viajem é só pra mim pagar a minha traia, que eu vou fazer, entendeu? Você fica p. da vida, você num qué nem, tá cum raiva do caramba. Só que vai acontecê alguma coisa boa lá na frente, você esquece tudo, aí ocê começa, quando ocê vai indo, ai ocê chega num lugar, ocê consegue arrumar uma pinguinha, entendeu. A pinga é, tipo, uma injeção de ânimo nos, no peão do estradão, você vai indo, 10, 15, 20 dias e nada, você num tem uma sobremesa, num tem uma salada, ocê num tem nada disso, é o arroz, a comida, é o arroz, feijão com macarrão, essa é o básico de todo dia a dia, e o café cedo. Aí chega num lugar, tem um barzinho, ocê passa muita necessidade também, sabe, (...), esses negócio, você ta na cidade, o cara vai lá, compra no bar um baixeiro que você quer comprar, pra usar na estrada, aí você acha, compra uma pinguinha, você fica nossa senhora, (...) fica faceiro, parece uma criança ganhando doce. (...muito barulho, interferência, alguém martelando, um ferro...)

- Aeahh, Aeeahh! Esse cavalo! (tocando o cavalo)

- Essa sua moto, ta novinha, né? Bem bonita.

- É, eu tirei ela depois que vim pra cá.

- Que nem eu te falei cedo, eu não tenho, eu não tenho nenhuma vontade, de, vontade de voltá, eu não tenho, porque, você ganha dinheiro, reunido, só que se você fazer as contas, é tudo retorno com você mesmo que você usa, traia sua acaba muito, e roupa. Roupa que você põe no estradão, você numa viagem de 40 dias aí, num presta mais, só pra aquilo, ai, você chega, e você quer comprar roupa boa, você tem que. Você compra uma calça boa pra uma viagem, você põe, só serve só pra viagem, porque já mancha, fica encardida, então ela só serve só pra viagem. Sempre que ocê chega, ocê tem que comprar um baixeiro, tem que comprar um pelego, aí você tem que fazer isso tem que fazer aquilo, então é uma coisa muito cansativo. O Cozinheiro, essa turma fala que não, mas pra mim é o que mais sofre.

- Vai sozinho também, né?

- E o Cozinheiro é o primeiro que levanta e o último que dorme, deita. Ele, e é uma regra, se o Cozinheiro gritar pra você, 4 hora, ele grita: ó moca. Num é café que ele fala, eles falam moca. Ó moca gurizada. 
- Moca?

- É. Aí ele dá a média de uns 5 minutos pra você ta ali tomando café. Se ocê quisé durmi, e num levantá e num se virá e num vim toma café, ele joga fora. Você pode viajar quantas vezes, mas você chegando na cozinha dele, na frente dele, ele pegá um bule assim, e balança assim, joga fora, ocê num pode falá nada. Porque aí se ocê ta com mau humor, problema seu. Se ocê perdeu a hora, problema seu. Porque ele tem todo um compromisso, ele tem que lava aquela vasilha que ele desencaixotou, tem que secar aquela vasilha, encaixotar tudo de novo. Espera as trempe dele esfriá, desmonta ela, puxa fora do fogo, esperar ela esfriá porque ele tem que encaixotar ela, por no tipo arforge de couro, que márra, que leva, pra ele ir viaja. Então quando você, enquanto ocê tem que só tomá o café, e pega teu cavalo pra encilhar, ele tem que levantar antes, fazê o fogo, fazê o café, tirar tudinho dali, esperar esfriá, encaixota, quando você for pegar o animar ele tem que ta pronto também pra ir pegar o dele.

- Ele vai, eles saem juntos, né?

- É, normalmente ele sai um pouquinho por último.

- Por último?

- É, por que? Porque é demorado, normalmente é 4 burro, pra ele ter que carregá os 4 , então são 8 caixa, é muita coisa, ele tem que arrumá...

- E ele vai sozinho?

- Normalmente, sempre sozinho, quando é, o gado é manso, e coisa e tão num lugar bom, sempre o Condutor deixá um pra ajudar ele, mas mesmo assim, ainda sai por último, porque os cara chega, pega ali o animal junto com ele, encilha, e já vai pro mangueiro, e do magueiro já soltando. Então ele tem que encilhar os 4 burro e ainda encilhar o dele. Aí o que que ele faz, ele encilha o dele, puxa o dele pro lado, aí ele vai encilhando os outro, porque cada burro tem a sua carga certa de carregar, entendeu? Os mesmo baixeiro, o mesmo tilim, por a mesma carga. Por exemplo, se ele chegou hoje, ele um pacote de macarrão, um quilo de arroz na janta, ele já tem que saber da onde ele, que caixa ele tirou, pra ele igualar o peso, porque a caixa tem que ta sempre o mesmo peso, $10 \mathrm{~kg}$ prum lado, $10 \mathrm{~kg}$ pro outro. Pra ele ir no balanço, pra não pisar o animal. Se pisá, tem que viajá. Então é uma coisa muito melindrosa, tem que ter muito cuidado, muita atenção. (Para encilhar põe baixeiro com a manta e o arreio, mais uma chincha. Aí as bruaca. Aí coloca as malas dos peões (os dobro). Joga-se um couro de vaca por cima do couro, o tilim, onde já tem uma chincha. Tem cozinha com trator, com carreta].

- E ele tem que conhecer muito bem também, né, por que vai sozinho?

- É, normalmente, tem sempre quem conhece melhor. Às vezes os peão viajado todo mundo conhece, mas como quem tem que prestar muita atenção é o Ponteiro que vai na frente, o Condutor, que é o responsável pelo gado, normalmente os outro vai indo, vai cunversando, vai indo, normalmente eles não prestam muita atenção nos detalhe. Mais o Ponteiro aprende a conhecer os caminho tudinho, fala, os desvio, os atalho, né. Então, vamo tira, vamo tira um atalho, né, o cara fala. Então ele sabe que a estrada vai aqui, mas se ele for aqui ele vai sair lá na frente. De tanto ele andá prestando atenção, ele já sabe. E muitos também que prestam atenção sabem, né. Mas eles não tem aquele, tipo aquele negócio de, como qualquer serviço, né, o chefe tem que fazer o (...) da tarde, ver que que ele fez, que que não fez, os outro que é só funcionário, sem compromisso nenhum, encerra o expediente, vão embora pra casa, então mais ou menos a coisa, é...

- A preocupação é maior, né? 
- Se o gado corre pra frente, a preocupação é do, a responsabilidade é do Ponteiro, que vai na frente. $\mathrm{O}$ que acontece muito também, porque se você chegar num lugar pra pousar, que não tem mangueiro, que num tem mangueiro, então o que que você faiz, se você já sabe que não tem mangueiro, as veiz ocê adianta (da Comitiva, pegam pá no almoço, Cozinheiro leva pá e machado)duas pessoas adiantam, ai vai fazer buraco, cortar pau e fazer uma cerca provisória que corta. Ce corta 20,30, (...), faiz poste, aí você usa um canto de cerca, né, aí você faz dois canto, tal, aí você passa a corda. Puxa, passa, fica fácil pra puxá e fica fácil pra você soltar e por de novo. Faz uma cerca pro lado de fora.

\section{- Nossa, e não arrebenta?}

- Não, não arrebenta, a corda é forte, uma corda de náilon. E se é na estrada, se num tem jeito, se é na estrada, você que que acontece, você tem que fazer duas simbras, uma na frente e uma atrás, que é pro carro passar. Aí que é mais complicado, aí a turma que trabalha na frente, dorme na frente, e a turma que trabalha atrás, dorme atrás, porque quando vem um carro, se ele vem vindo da parte de trás pra frente, algum de trás vai ter que abrir a simbra, aí ele entra devagarzinho, bem devagarzinho ele vai indo, porque quando ele chega lá na frente, o cara lá da frente que abre. Se vem de lá pra cá a mesma coisa, então o cara tem que ficá (...) cuidando, se o gado não vai estourar, num vai arrebentar, se derruba a cerca, porque a corda ele num, sempre num acontece de ele arrebentá, mas ele pode derrubá a cerca, porque é uma cerquinha provisória, buraco raso, num é socado, igual é socado num cerca. Só que o gado acostuma, porque o gado viajado ele cansa, então ele fica muito manso, muito próximo. Então ele chega de tarde, no pouso, ele só quer deitar, ele não se preocupa muito em levantar e ficar andando e nada, ele só quer deitar. Chega e deita, então, não dá muito trabalho. Mas quando é uma boiada meia... que recém saiu, que tá pra começar uma viagem ainda, que tá inteira ainda, ta bem gorda ainda, e que começa a ter muito movimento de gente, de carro, ela normalmente, ela quer correr, quer... é o tipo de coisa de $7,8,9,10$, dias ela já num (...), (acomoda. Gado deu uma aquebrantada, aí pega o batidão].

- Se ocê sai com uma boiada, aí, no primeiro dia, ela corre, estoura de você, dá um trabalho pra você juntar, reunir ela de novo, sair, depois de 5 dias, você vai vê ela, você num conhece, num fala que é a mesma boiada. Vai fácil...

- Hoje tá mais fácil Olivia, hoje, quase todo lugar por aí tem corredor, então o trabalho que ocê tem é de enfiar o gado lá dentro e ir prestando atenção nas cercas, se não tem nenhuma arrebentada, costada (...) e ir beiradiando e sair. Só isso. Tipo esses corredor que sai aqui na fazenda, hoje tem daqui de Aquidauana que sai até muito dentro?, desse Pantanal, tem corredor. Fazendeiro se preocupa muito em fazer corredor não só pra facilitar o trabalho do boiadeiro, não só pra isso, também pra facilitar um pouco o trabalho do boiadeiro, mas mais pra preservar o campo dele. Porque o boiadeiro ele num ta nem aí, se vê um campo bom assim de pasto, bom, ele fica enrolando com o gado, pro gado comer, e as veiz falta pasto pro gado dentro da fazenda. Então, já fez o corredor, então onde que é, já é bem limitado, né, uns 20 metros de largura, aí ele pasta só ali, ele perde pouco pasto

\section{- É mais porque ele fica comendo, não é porque fica pisando?}

- Não, pisar é natural. Se tem uma boiada com 1.000 bois, e quando ele passa no (...), passa naquele pasto assim, ele rapa tudo, ele passa ta com fome, ele rapa, ainda mais quando ele vê o boi, ele ta com fome, então ele rapa...

- E... Eu to pensando, nesses corredor, eu passei nesses corredores agora, a última vez que eu fiz, que eu acompanhei a comitiva e... não precisa também do meeiro, né?

- Não, o meeiro fica com o Condutor, aí ele fica na culatra. (No corredor vão 3 na frente e 3 atrás. Em campo aberto: culatra para o gado fechá. Em corredor fica fixo, 3 Ponteiro e 3 
fiador, 2 culatreiro e Condutor atrás]. Por isso que eu falo pra você, despois que saiu essas coisa agora, tá bom de viajar, porque o peão não tem muita preocupação, não, porque antes era tudo aberto, então tinha que ir do lado, tinha que organizá a boiada, tinha que esquadrejá (exemplo, mantém dentro do quadrado)a boiada, né. Eu trabalhava direto nisso aí, ia e voltava. Se sai de tráiz, vai lá no meio da boiada e volta, vai lá no meio e volta. Quem ta na frente, na lateral, que fala fiador, vem até no meio de onde ocê ta e volta, vem até no meio onde cê ta e volta, então a boiada tem que ir esquadrejada. Então, era bem, cansativo, nossa, agora não, agora ta fácil. Cê, tipo, ocê vem lá do retirinho, são $70 \mathrm{~km}$ pra você chega em Aquidauana, você não tem trabalho nenhum, você só solta o gado do mangueiro, e cê já sai com o gado pro mangueiro, você sai dentro do corredor, dos mangueiro já tem entrada já pro corredor, entrada e saída pro corredor. Então ocê não tem trabalho nenhum, cê tem que ta ali, o trabalho é que você tem que tá ali, né. Se pega, por exemplo um corredor sujo de mato, tem que ir devagarzinho, tem que olha se não tem caminhão parado na beira, por exemplo atrás.E na frente,e os fiador que vai na frente tem que ir olhando se não tem um vão, uma rabada, se ele não ver, e o gado for ali coxeando a cerca, ele vai vará, porque ta bom de pasto pro outro lado, aí ele vai querer varar, varar, onde que ele extravia, e perde e tem todo um trabalho depois, de ta voltando, pra ir atrás, é complicado. (...) pra você trabalhar, pra você desgastá, cansá, até você como o animal descansa muito, hoje, é mais, mais tranqüilo.

\section{- (Meeiro ou esteira?}

- Já não usa mais, mas fala, vô fazê um costado, uma esteira aqui, para esses gado não abri. Forma-se um cordão de cavaleiro ao lado do gado para que ele ande esquadrejado, normalmente onde tem mato, para o gado não correr].

\section{- É duro também, que nesses corredor é mais difícil para pegar água, né, ou não?}

- É mais difícil, mas normalmente, sempre em algum trecho do corredor assim tem uma, uma parte que tem é bem mais larga no corredor, então sempre eles deixa, eles fazem já o corredor com essa preocupação, de deixá sempre um lugar onde nunca seca, ou que tem um açude que é feito com máquina entendeu, faiz um açude, né, aí faiz aquela parte mais larga assim, que serve pro cara reuni o gado, fechá o gado, porque normalmente o gado, quando você vai armoçá, ocê arroia o gado. Que que é arroiá?

- (vi isso na terceira comitiva que participei) Arroiá, ocê fica raiando, você fica dando de roda nela, gritando com ela, raiando e surrando com o arreador, táh, táh, táh! Vai surrando com o arreiador, aí ela por si, ela vai ficando, ela vai se embolando e vai deitando, ta cansada e tal, aí as veiz ela toma água, ela já sobe pra toma água e sobe, e fica parada ali em pé, aí você começa a ralhar com ela, e surrá com o surrador, ela deita, fica um bola, fica tudo deitado, aí as vez, vamo dizê, numas 500 rêis, as veiz 10, 15,20 fica de pé no meio ali, de pé bem no meio dormindo, as outra fica tudo deitada. Então, mas você tem que tê cuidado, tem que ficá cuidando, então fica lá conversando, um com o outro, olhando o gado e conversando, isso daí é arroiá. Então os fazendeiro, já pensa, já pensam nisso, já faz onde tem a água, a aguada, né, um lugar mais aberto assim, já lá na frente ele já segue e pega o corredor de novo e aí fica numa largura já normal, né. Então é assim, sempre tem um distância normal, tem uma, quando não tem, o cara faz um desatador, um desatador, tipo um simbrão, sabe, se tem um açude bem pertinho do corredor, assim sabe, aí ocê abre aquele desatador ou a simbra, você vai lá da água pro gado e vorta de novo. O fazendeiro não gosta que você anda no campo dele, porque tanto você pode perdê gado, num é o problema de você perdê, o problema é de você, tem muito nêgo também, que usava de muito ma fé também, né, o gado do fazendeiro enlotava no meio do gado, da boiada e levava embora, cê entendeu, é, vamo supor, de 20 Condutor, uma veiz sempre tinha um que era meio malandro, 
então levava muito gado de boiadeiro, de fazendeiro, né. Então, o fazendeiro, vamô fazê corredor, né, então passa aqui, então é. Tem veiz também entra e enlota, as vez sem o cara querer, ocê entendeu? Daí, o que que o boiadeiro faz, num vou parar aqui que é muito trabalho, então eu vou indo, a hora que ele acha um lugar lá pra frente, ele laça a reiz, ele volta, tira pra cerca, né, mas sempre tem as veiz, tem argum que é mau funcionário.

- Então é mais ou menos isso...

- E hoje tem muito também, estrada, né? As vezes estrada de cascalho, asfalto? Você chegaou a passar...

- É mesmo, normalmente, é estrada de cascalho, você só anda nela em último caso, quando não tem corredor, que nem a estrada que você vai pra Porto Murtinho, Porto Murtinho, você vai subir a Serra, fala vamo subir a Serra lá no Porto Murtinho, então não tem assim quase, tem lugar que não tem um corredor, basicamente estreito, tem um corredor já, mas é o corredor que tem (...) da estrada, é não é bom, largão?, né. Tem a estrada no meio, e uma cerca do lado de cá, assim, $70 \mathrm{~m}$ tem uma cerca e do outro lado tem a mesma coisa, então acaba sendo um corredor, porque o gado num vai. Só que o que que a gente faz, a gente não usa muito, ou joga o gado pro lado esquerdo da estrada, na parte de chão, ou pro lado de fora, só anda no cascalho em último caso, porque senão a boiada, a tropa num guentá, tropeia. Quando num tem jeito que é só cascalho, aí você vem tem que ir bem devagarzinho, mas normalmente é pedacinho curto. É, e o asfalto também, né, você anda no asfalto em último caso, você pode ver, as veiz quando encontra gado no asfalto, na BR, mas é arguma rêis, as veiz, e quando não dá pra ele andar na lateral do asfalto, que eles numa andam. Só quando tem que andar no asfalto, tem que usá, mas pode ver que sempre tem, na frente da boiada, há uns 500 metros, tem uma pessoa com uma bandeirinha vermelha, que significa que tem gado na estrada, então, pra turma vê e diminui, porque pode atropelar uma rêis, acontecê um acidente, basicamente é isso.

\section{- Quanto tempo faz que você parou?}

- Que eu parei, olha, pará, pará, pará mesmo, eu não parei, porque antes deu eu vim pra cá, eu fiz umas treiz pitoquinha, antes de vir pra cá, foi em 2005, eu fiz umas três pitoquinha, aí eu não tinha traia, não tinha nada, aí, como eu tenho um Condutor, que eu sou muito conhecido, sou muito amigo do filho dele, então, ah, vamo viajá com nóis, vamo fazê uma pitoquinha lá. Então, eu ah, eu não tenho traia, num tenho traia, não, larga a mão. Ele falou, ah não eu te dou a traia, eu te dô a traia, eu te dô a traia pra você ir cum nóis, pô, larga a mão, aí eu peguei, acabei fazendo três pitoquinha, foi em 2005. Fiz uma de 18 dias, uma de 12 e uma de 6 dias. Três pitoquinha que deu certo de pegá então deu certo, sabe. Tudo dum lugar só, só que uma demorou, uma demorou uns 18 dias, porque nóis fiquemo 10 dias só dentro da fazenda, trabaiando o gado dentro da fazenda, ajeitando a boiada pra sair, sabe, tirando o gado da invernada, levando pro amngueiro, apartando, sabe. Aí depois fiquemo amansando o gado lá dentro, amansemo tudinho, aí nós, por isso que nóis demoremo tanto tempo, aí ainda demoremo mais 6 pra chegá até em Aquidauana. Aí as outra foi tudo...

- Da onde que era?

- Na fazenda São Salvador.

- Mas é Miranda? Onde que?

- Não, é na reta que vai pra Barra Mansa, que vai pra Rio Negro. Fica tipo, uns, fica tipo uns $60 \mathrm{~km}$ de, ir pra Fazenda Rio Negro.

- E aí, mas eu não sabia também que as Comitivas trabalhavam gado? 
- Mas é, depende do Condutor e do fazendeiro, sempre, normalmente, você vai pegar, às vezes quando você ta trabalhando, você vai pra você arrumá o gado, porque as vez você num tem como você chegar lá e pegar uma boiada, a boiada que tá lá você pegar e sair, você tem que amansar a boiada, né, senão cê sai, cê perde tudo o gado, o gado nunca fez aquilo, não tá acostumado, então você tem que fazer um treinamento com o gado. Você pega, reúne o gado, você põe numa invernada que tem cerca boa, normalmente numa envernadinha piquitinha, aí você sai com ela, surrando, falando, aí vai se ocê leva uma boiada brava, aí vai andando até um pouco assim, daqui um pouco ela estoura quase tudo. Aí você tem que ir lá, ela vai correr até no canto da cerca, aí ela para. Aí você vai, lá, você reúne tudo ela de novo, esquadrejá ela e sai de novo com ela, como se fosse viajar no estradão, aí ela vem, corre de novo, aí no outro dia, aí ocê larga dela naquele dia. No outro dia ocê vai e novo. Aí, você só sai com ela quando você sentir que você tem segurança de sai, que se ela correr você vai dominar, entendeu? Porque tipo, bezerro mesmo, desterneiro, normalmente o cara treina numa base de uns 2, 3 dias antes de sair, o cara doma, fala vou domar, vou domar uma boiada, é fazer eles entender como que ele vão ter que viajar, entendeu. O único sistema de cê chegá, pega um gado e levá, é só o cara embarcar no caminhão. Já chega, embarca e leva.

- Tem muita gente fazendo isso, agora, né?

- Tem, a maior parte, né, tanto é que diminuiu muito, hoje em dia eles não tão conseguindo tirá Comitiva, tem lugares que não tem acesso a caminhão de gaiola, aonde vai caminhão de gaiola, ais ocê vai, oce vem com uma boiada lá do outro lado do Taquari, então ocê chega no Retirinho, por exemplo, ocê já embarca, já tem embarcador, já tem estrada boa, cascalhada, então o caminhoneiro já ta lá esperando já pra embarcar, aí você embarca lá, entendeu. Então já diminuiu, já diminui, tipo, as veiz 30 dias de viajem pra frente, diminui. Antes você fazia viajem de 100 dias, 110 dias, 120 dias, hoje no máximo que você faz aí, quando acontece, dependendo do lugar, é tipo uns 70 dias, 80 dias, entendeu? Não tem mais aqueles viajões de 4 mêis, porque tem muito lugar pra embarcá, então o cara já embarca.

- E as veiz ocê pousa num lugar duas, treis veiz, num lugar, sem ocê sai daquele lugar, quando você vai, quando você vai pastorejá, pastorejá significa, só solta do mangueiro, aí o fazendeiro te dá uma invernada pra você dá pasto pro gado, que já tá muito fraco, num ta conseguindo viajá. Aí você fala vou pastoreja, dai o cara acerta lá com o cara lá, o fazendeiro o preço que ele vai cobrar e ocê solta o gado naquela invernada e cuida ele, igual cê ta viajando no estradão, né, vai acompanhando ele, cuidando, vira pra lá, vira pra cá, aí quando ta chegando na hora de encerrá, ocê sai de vorta pra encerrá, aí no outro dia, você vai (...), solta pra pastoreja de novo de manhã, aí recolhe pra almoçá.

\section{- Isso pra deixa ele, pra não emagrecer?}

- Não, é, pra não emagrece tanto, pra ele agüenta viajá, senão ele fica muito fraco. Porque no corredor ele vai comer o que vê no corredor, de repente quando você vem vindo com uma boiada assim, passou duas na sua frente, então já comeu o que tinha, então normalmente, muito pouco sobre pra ele comê. Aí chega no ponto dali 20, 30 dias, que ele ta muito fraco, aí ocê tem que arrumá algum lugar para, e dá pasto, dois, três dia, pra ele se refazê de novo. Você entendeu (...). Então em isso aí, num vai pegá e sai, 40 dias num lugar, numa época, ainda mais no meio da seca, sai, cê num chega lá, a hora que ocê chega, é só metade, o resto fica pelo caminho, magro, morre, tropeia? Então você tem que ir cuidando a boiada, quando ela ta fraca, ocê arruma um pasto, se arruma um pastoreio pra ela, e dá pasto.

- Eé o Condutor que decide isso, não é o fazendeiro? 
- Não, é o Condutor, porque ele que ta vendo como é que ta o gado. Se tem arguma fazenda que tem telefone, ele liga, né, e fala o eu vô, o cara fala, falhá, eu vo falhá lá em tal lugar. Falhá é que ele vai pousa, vai repetir ali. Eu vô fala, então o que eu vô fazê, eu vô ficá 3 dias pastorejando aqui. Ah ta, ta bão. E o cara, normalmente na viagem, o cara sabe o dia que sai e o dia que chega. Cê conta, nóis vamo vim, nóis vamo pousá nessa fazenda, vamo pousá em tal fazenda, vamo em tal fazenda. Nóis vamo ficá 5 dias trabaiando o gado, ajeitando essa boiada, aí nóis vamo pastorejá em tal fazenda dois dia, então ocê já tem uma conta certa, você entendeu, ocê já tem uma conta certa. Basicamente erra por um dia, dois, no máximo.

- Até mesmo porque daí que ele fala o preço, né, quanto é que vai...

- É, normalmente o cara já tira, já tem a noção, então já tira adiantado, os dia calculado, o que ele qué, que vai ganhá, né.

- Ahhééhá, sai daí! (cavalo novamente interferindo)

- Que mais, só pra terminar então, é e você sente falta de alguma coisa, da Comitiva? Ou mesmo de trabalhar no campo assim...

- É, eu sinto falta, eu acho falta de quando ta (...) de ver essa turma correndo no campo aí, pegá uma vaca, laçando, eu acho falta, só que despois eu penso bem, éé...o peão é muito desvalorizado, o salário em si é muito baixo, aí então, daí eu já não acho mais falta de novo. Hoje se eu trabalho uma semana, duas semanas ajudando no meio deles, pra mim já ta bom, eu já fico tranqüilo, fico tranqüilo, mas se eu ficá um ano sem andá a cavalo, sem pegá um gado, sem coisa assim, eu já fico doidinho pra fazê de novo, aí eu faço, daí passa minha vontade de novo.

- Porque quem é, quem trabalha nesse ramo, se não for capataz, se não for alguém que tem um cargo que ganhe bem, ele só vai conseguir arguma coisinha, só se ele fica 5 anos, seis anos, sete ano na fazenda. Porque hoje ele sai, recebe um dinheirinho, aí compra uma casinha, humilde também. Então ele nunca vai passar disso, de ter aquelas coisinhas básicas, dele ali. Um sofá, uma geladeira, uma televisão e só. Não pode, não tem, não consegue comprar um carro bom, porque não adianta que ele não consegue compra, porque o salário não ajuda. Porque quem pensa em comprar uma casa boa, ter carro bão, esse serviço é muito difícil. Dependendo o que é que faz, o capataz, o retireiro ganha bem, o gerente, (...), o capataz se fala eu vou compra um carro pra mim no final do ano, compra porque ele tem um salário bem diferenciado dos outros, entendeu, o gerente, ganha tipo 10.000,00 real, só de salário, aí tem comissão de venda de gado, tem num sei o que, tem uma cota que ele pode gastar, e tal, e o que ele não gastá ele tem tantos de recompensa, pela aquela economia que ele fez. Quando você pensa que não ele tá fazendeiro já, (...) ele já ta.

\section{ENTREVISTA I (B)}

- Pois é Olivia, tem uma fazenda que chama Capão Verde, é próximo da fazenda Pequi, lá tem um garpão que quando os peão duvida acontece muitas coisas, por exemplo, eu, no caso diz que alguém faleceu nesse galpão, nesse galpão aonde posa, posa a turma, então que que acontece, se o cara chega lá, e num pedi licença e armá a rede num certo esteio do outro, quando ele tá durmindo a corda cai, aí o cara cai no chão, entendeu, daí, e o cara, o cara pra podê dormi bem nesse lugar ele tem que chegá e pedi licença pra usá o armadô, porque senão ele, se ele duvidá, ele tora a corda dele e ele cai. Então ficô, a gente chama de garpão assombrado e quase ninguém gosta de pousá lá por causa disso, sozinho, o nego tem medo de 
pousá lá, isso num é uma lenda, uma coisa, isso foi um causo acontecido com várias Comitiva, um foi contando pro otro, então hoje em dia, a turma desvia de pousá nesse garpão, a turma evita, sempre aumenta um poquinho a marcha ou diminui um poquinho a marcha, por causa desse garpão assombrado. É isso...

- Pede licença pra algum lugar ou só fala o nome?

- Não, pede licença pro: - Ôu você, que é dono desse armadô aqui, da licença que eu quero dormi aqui, que eu tô cansado, viajei muito, trabalhei, deixa eu durmi aqui sussegado.

\section{- Fala em voz alta ou só pensando?}

- Fala em voz alta. Faz um pensamento, porque todo fala, criou um certo medo geral, né, porque dum peão de Comitiva, passa, conta pro otro, né. Então tem cara, tem muitos que duvida. Qué! aqui tem lugar assombrado nada eu vô durmi aí e cabô e normalmente ele se ferra, ele sucateia com isso, sucateia com isso, e as veiz corta a corda dele mesmo, ele cai, então hoje, numguém mais, depois de um certo tempo, ninguém mais duvida, sempre pede licença.

\section{- E já evita também de passá lá?}

- É.

\section{- Porque mesmo assim, ele fica com medo?}

- É, sozinho é compricado. Tem várias fazenda por aí que tem história que foi arrancado o enterro, né, foi arrancado o enterro, então aquele lugar ficou mal assombrado, enterro que que significa enterro, a gente fala, arrancou o enterro. É que antes os fazendeiro num depositava, num tinha dinhero em banco, e antes era moeda, tinha assim muita moeda, dinhero, então eles num depositava isso em banco, eles depositava, fazia um baú, de madeira, né, e guardava o dinheiro ali, e quando eles tinha muito dinhero, que que eles fazia, eles tinham medo de sê robado, eles interravam em algum lugar que só eles sabiam, aí o que acont... o que podia acontecê, ele morrê e aquele dinhero ficá enterrado e ninguém sabê, daí, como aquele dinhero foi enterrado, ele queria passá pra alguém aquele dinhero, depois de morto, então que que ele usava, ele usava tipo, um fogo, uma luz, é... conversa, pra atraí alguém até achá alguém que tivesse coragem de chegá, de atendê esses tipo de coisa pra atendê, e í lá pra cavocá pra enterrá, porque muitas vezes isso tem na estrada, ocê vai indo numa estrada assim escura, num tem nada, nada, de repente ocê vê aquele farolzão de carro que vem, que vem vindo, aí você anda, anda, anda e de repente some aquela luz, você fala, ó o cara parô, apagô a luz. Aí você vai olhá num tem carro, num tem batida, num tem nada, entendeu. Então, aí o peão fala assim, tem um enterro ali. E tem uns que tem medo, e chega arrepia o corpo e se num chega ali naquele lugar. Tem muitos que veiz nasce um fogo no pé da, da madeira. Aqui na Caiman, tem uma história dessa, diz que foi arrancado, se eu num me engano, um enterro, é na frente da onde hoje ali é um salão de baile. É, tem essa história que foi arrancado um enterro dali da Caiman, em frente ao salão de baile.

- Em frente ao salão de baile...

- É em frente ao salão de baile, da pista de laço nova. É, tem essa história, então tem várias histórias...

- E o cara que morreu, que tem o dinheiro, quer que o outro pegue o dinheiro, pra aproveitá o dinheiro?

- Quer que o outro pegue. Isso. Então, como ele não pode.. 
- Ele não vai querer matar o cara...

- Não, como ele não pode falá, então ele usa o que muita gente duvida, a... o que a turma fala, né, morreu, mais o espírito véve, né. Então através dessas forma de mostrá uma luz dum carro e mostrá uma vela acesa, arguma coisa. Por exemplo, nessa fazenda, perto, próximo da Santa Virgínia, que eu te falei aquela hora, também foi arrancado um enterro dum pé duma figueira, viu. A figueira era muito novinha e o cara tinha enterrado um baú com dinhero. Aí toda vez que a gente passava lá, acendia uma luz, alguma coisa assim, as veiz chacoalhava uma árvore e a maioria dos caras num pensava que era enterro, assustava, pensava que era assombração e não tinha coragem. Aí diz que um dia, um certo dia, uma pessoa ia passando assim, e viu aquela luz naquele pé de figueira, né. Aí ele chegou nela próximo, né, aí diz que a luz sumiu, aí ele perguntô: - Quem que tá aí com essa lanterna aí brincando? Tá achando que eu tenho medo, eu num tenho medo não. Acende a lanterna, onde ocê tá? Daí diz que demorô, demorô, ele falou assim. Ah, tá brincando comigo, eu já vô embora, hein. Aí diz que tornô a acendê uma lanterna, aí diz que bem no pé da figueira. Ele viu uma luz, como se fosse uma lanterna, no pé da figuera. Aí ele falou, isso aqui é um enterro, eu vou arrancá. Aí diz que ele cavocô e tirô o baú ???? 06:09, diz que era.

- $(\ldots)^{124}$

- Então, mais essas histórias que eu, que nem eu tô contando pra você, aqui tudo são reais. Então, isso aqui é uma história assim, que tem muitos, tem muito, gente que tira enterro, né, aí ele acaba contando pra outra pessoa, então as veiz acontece isso, né, Olivia, seu eu tirá o enterro, muitos tiram o enterro e não conta pra ninguém, aí de repente some aquela pessoa, e fala assim, ah eu vou embora, pra ôtra cidade, num sei o que, porque ele fica com medo de contá, e alguém querê matá ele pra tomá, né. Então, por isso que tem veiz que contece que a pessoa some e de repente quando volta, volta com carro, volta bem de vida.

- Então, e tem outra? E de boiada estourá, de alguma coisa que aconteceu assim, com a boiada?

- Tem, acontece as veiz de ocê passá cuma boiada, tipo, nim ronda, também as veiz acontece de o cara gritá, estralá arreadô, como se fosse, tivesse vindo uma boiada, arguma coisa assim, nada disso... o gado assusta, corre e num é nada, num é ninguém. São, o que que são isso, são boiadeiros, antigos peões de comitiva, que ali pousavam. Então pra eles, eles tão vivendo de novo, tão viajando, eles tão vivo, eles tão viajando. Então é uma manera de usá e que a turma fala que é assombração.

- $(\ldots)^{125}$

- Tem muita coisa que a gente não consegue explicá (...) Isso acontece muito a gente tem muito. No meio de pobre isso é, é normal. (...) .

- Aonde tem muito lugar de força negativa, é onde aconteceu, as vezes, muito tempo atrás, muitos lá atrás, 40, 50 anos atrás, muita morte por briga, entendeu, muita morte por briga. Turma querendo toma terra...

- $(\ldots)^{126}$

- Você já ouviu falar de uma, porque eu tô fazendo trabalho sobre comitiva, né, por isso que eu, porque o Juarez já fez comitiva, então eu vô falar um pouquinho das histórias de

\footnotetext{
${ }^{124}$ A esposa do entrevistado (Sueli), continou a história sobre o "enterro" na Caiman. Apesar de muito interessante, como não estava diretamente relacionada ao trabalho, teve que ser retirada. O arquivo de aúdio foi digitalizado e será depositado junto com a dissertação para posteriores estudos da pesquisadora, ou de quem estiver interessado.

${ }^{125}$ Idem, nota 1, incluindo outras histórias sobre assombrações.

${ }^{126}$ Idem, nota 1, mas nesse caso, contando a história sobre a morte de uma pessoa na Caiman. Juarez também comenta a história da cruz na beira do rio Aquidauana.
} 
assombração porque acho que tem muito na Comitiva,né? O pessoal conversa muito também, né? Acho que a noite, já dorme com medo, já aí, né? E... tem uma história que fala na Caiman, de passar uma Comitiva, de vê Comitiva passando naquela ponte, você já ouviu falar?

- (Sueli) Ahã, na Baiazinha ${ }^{127}$ também.

- Na Baiazinha também?

- (Sueli) Na Baiazinha também.

- Fala de ver uma boiada, não sei não lembro.

- (Sueli) Ahã, e vem aquela boiada, aquele barulho, mas aquele barulhão de boi, você vai vê num é ninguém, num é nada, é verdade mesmo. Passa sabe por onde? Começa ali na ponte, na boca da ponte e termina ali no, na onde era o colégio, debaixo daquele pé de tamarindo. É ali que termina, o barulho. Vem, vai longe, a boiada, vai bem longe mesmo. $O$ meu pai já ouviu esse barulho de boiada, o meu pai chegou até corrê, que penso que era boiada mesmo.

- Dizem Olívia, que quem vê, é porque pra um desses, às vezes você ta em 5 pessoas, 1, 2 vê, 3 não vê nada, aí cria essas dúvida. Então esses que vê, é pra ele que ta oferecendo o oro.

- (Sueli) Ahã, é lá debaixo do, daquele pé tamarindo que fala que lá tem.

- Aí o cara fala, mentira, eu num vi nada, num é que ele num viu, num é pra ele, dá pra quela otra pessoa. Então, é isso que acontece muito. Que as pessoas num, num é que...

- $(\ldots)^{128}$

- Meu pai também conta umas histórias dessa, Olivia, as turma duvidava, né e coisa, mas desde quando nóis era criança, desde criancinha ele contava pra nóis que nem tudo que se vê, cê pode acreditá e pode confiá, estranhos principalmente, ele falava. Um dia ele viajou um pedaço diz que no estradão, aí ele voltou pra arribá o boi, deu um trabalho pra ele, ele falô: Mas barbaridade! Esse boi tá me dando trabalho e eu sozinho, né, ah, vô tomá uma água, tomá um tereré aqui, ele viu assim uma lagoinha, desceu do cavalo, fez um tereré, tava tomando um tereré e vinha vindo um cavaleiro, aí diz que ele parô lá, diz que tomô tereré com ele, e ele falou tô arribando pra lá.

- Pra ocê arribá é assim, né, você, se o boi entra numa mata, você fala, (...), dos cavalo, e tal, aí ocê entra na batida dele, né, pra vê pra onde que ele foi e tal. Aí ele falô, ah, ehhê! É ajudo ocê, ocê tirá esse boi. Ele falô: Ah rapaiz, então tá bom! Então, eu tô indo pra lá memo, preciso de ajuda, aí eles tomaram tereré tudo ali, daí saiu (...) pra, pra arribá o boi, aí diz que acharam o boi, aí deram um tropé nesse mato, lá no boi, ai ele háháhá, háháhá, aí diz que, diz que vinha o homem, vinha gritando assim, com o boi assim, aí o boi saiu pro meu pai assim, meu pai saiu com o boi no limpo, hôhhh! E o cara sumiu, num tinha ninguém, num viu mais nada. Sabe que isso aí é o cara devia viajá, de certo tinha falecido por ali, devia (...) por ali, vivia viajando, e aparecia assim pra...

- Lá perto da fazenda aonde eu fui criado, mataram um peão de boiadero lá. Quem que achou o corpo dele lá foi o meu irmão, o Jair. Eu tinha 14 ano e o Jair tinha 13. Aí a gente tinha parado já de entregá leite, a gente tirava lá na fazenda e levava de bicicleta pra entregá lá na cidade, de madrugada, porque tinha que tirá o leite, por no garrafão e levá pra cidade e entregá pra í pra escola de manhã ainda, então tinha que ser madrugada. Aí meu irmão ia passando e sentiu um chero forte, chero de carniça, né, ele ficô curioso, (...) coragem, ele falô, ah, eu vô oiá o que que é, diz que parô a bicicleta, a bicicleta carguera, né, parô a bicicleta, puxô, parado ali, pegô a lanterninha dele e saiu em cima dum peão morto, tava podre já, tava

\footnotetext{
${ }^{127}$ Baiazinha é o nome de uma das pousadas da Caiman.

${ }^{128}$ Idem, nota 1, mas nesse caso contando histórias sobre a "mulher sem cabeça" e "mulher de branco".
} 
de bota, chapéu, tudo. Um peão de boiadeiro, então ele conta a história desse cara lá que aparece. E eu conheci o cara. A turma conheciam ele. Tiveram arribando uns boi lá, uns quanto dia, entendeu.

- Eles iam toma cachaça e volta de novo, pra pastoreja

- Toma uma pinga e vinha (...) voltaram, aconteceu uma briga na estrada, assim uns $3 \mathrm{~km}$ da fazenda, aí os companhero dele brigaram, depois pegaram o cara lá e matô ele, é, deu uma facada nele e matô, matô ele assim, ele caiu do cavalo, né, ele caiu do cavalo assim e ficô, tanto é que nóis foi mexê com ele, foi tirá da bota dele, a carça, o pé saiu tudinho, ficô só o osso, aí num tem como mexê com o corpo mais, a polícia é por isso...

- O cabelo tava tudo saindo, sabe, pegava assim, saia tudo

- Num esquece, né?Fica na memória.

- E hoje tem história desse cara aí. Qué vê, faiz 30 anos, eu tinha 12, agora tô com 42. Faz 30 anos, história lá, quando passa sempre dô uma parada naquele pedaço assim (...). E bem em frente da onde ele morreu, da onde enterraram ele, tinha um pé de tamarindo. Encostado no pé de tamarindo. Ah, ele tava lá parado em frente do pé de tamarindo. Nóis num vimo ninguém não. As veis acontece isso

- $(\ldots)^{129}$

${ }^{129}$ Idem nota 1, nesse caso, história da assombração no quarto 11 da sede da Refúgio Ecológico Caiman. Em seguida, Juarez conta história da assombração do empreiteiro e logo após, Sueli conta história da assombração do "homem da capa preta", entre outras. 


\section{ENTREVISTA II}

\section{José Aparecido Francisco da Silva (Barriga)}

- Entrevista realizada em Maio de 2009, na Pousada Xaraés, Corumbá-MS.

- Barriga é ex - peão e peão de boiadeiro. Em Maio de 2009 era funcionário - guia de campo do PousadaXaraés.

- Apelido?

- Idade? 31 anos

- Aonde que você nasceu: Eu nasci, eu nasci no municipio de Rio Negro, fui criado, no Rio Negro.

- Família? Luan (filho, 6 anos, mora em Corumbá pra poder estudar), é casado com Sueli

- Escolaridade: Ah, bem pouco, na primeira série

- Você tem religião?

- A relião é o que a turma, n sei, é católico? é católico, ne?

- Você acredita em Deus?

- Acredito

- Então tá, agora vamo fala de comitiva, quando q voce começou a viajar, como que voce aprendeu? Como é que é a história?

- Ah, eu comecei, desde pequeno assim, viaja, viaja, eu viajei bem pouco no estradão assim, mas na fazenda eu comecei mais ou menos assim, de 11 p cima assim, eu ja mexia no campo ja.

- Lá no Rio Negro?

- É, aqui memo no pantanal, a partir de 11 ano. Ai eu fui trabiando no campo asim. Aí eu fui aprendendo, acompanhando o pessoal no campo, ai eu fui aprendendo.

- Mas era sua familia, seu pai? Quem q ensinava?

- Não, com os outro. Eu aprendi com os outro. Assim, voce saiu, foi trabalhar por conta ja da pessoa, por conta minha. Aí fui aprendendo. Ocê trabaia com muita familia, ocê não aprende nada, viu? É mai difícil, porque a familia qué briga cocê. E os outro, que num é parente seu, ensina melhor q é parente, né, mais ou menos, o serviço.

- E aí qdo você começou a fazer comitiva, mesmo fazendo pouco não tem problema, mas você lembra como é que foi? Como é que era?

- A comitiva. A maioria das comitiva q eu andei foi mais de fazenda, assim, de fazenda, leva gado pro outra fazenda assim, mais ou menos uns dez, doze dias assim, voce andá na estrada assim, viajando. É ocê saí com o gado e vai pousá na outra fazenda. E sai cedo, encilha os cavalo, cê levanta, arruma o, a mala, e ai ocê vai pega os cavalo seu, o burro, porque anda mais no burro, ne. Aí, você vai sorta o gado. Aí, ocê vai devagar, dando pasto pro gado, vai devagarzinho até chegar no ponto de armoço. Aí o Cozinheiro vai tá lá já, esperando cum o armoço pronto. Aí você armoça e troca de animal também de novo, sorta aquele que tá de manhã, pega outro a tarde proce chegar até na outra fazenda, mais devagar, né. Você anda mais ou menos umas 4 léguas assim, durante o dia. 
- O que que é quatro leguas?

- 4 légua, dá , acho que 24 km. É 6 km cada légua. Então, aí no outro dia é a mesma coisa, é aquele serviço direto, né, ate chegá. Entao é sofrido memo, viajá.

- E você falou comitiva de fazenda, porque você trabalha na fazenda?

- Trabalhava na fazenda

- Não é comitiva q sai só pra fazer comitiva, é comitiva, é que trabalha, é isso?

- É trabalha, trabalha, eu viajei uma vez só numa, na Comitiva assim, de estradão memo assim, mas só que eu viajei poucos dia, porque eu peguei ela na fazenda que eu tabalhava, aí eu fui na Comitiva.

- Você quis ir, como é que foi?

- É eu, passando meu cunhado e eu queria embora da fazenda, aí ele falou então vamo embora, e aí eu fui!

- Foi embora na Comitiva?

- É aí eu fui na Comitiva, mas só que eu era novo, não sabia quase nada ainda de Comitiva, então eu ia no meio do pessoal, assim, só pra ir ajudando, aí eu fui tranquilo.

- Você tem um tio também que?

- Não, meu cunhado, que é casado cum uma irmã minha. E aí...foi...

- E...peraí que eu tenhi um monte de pergunta ainda. E você levava gado de onde pra onde, você lembra, quando você fazia as de fazenda, ou mesmo essa que você fez, que região...?

- Uma vez eu fiz uma viajem alí, de perto do Rio Negro, chama Corguinho, ali, uma cidade, eu acho que todo mundo conhece aquela região ali, nói levemo pra de lá perto do São Gabriel do Oeste, foi 13 dia de viajem, aí nóis peguemo esse gado e levemo lá. Passsemo por Camapuã, ali...

- E você ia de Ponteiro? Qual que você ia mais?

- Sempre eu trabalhava, tem a posição, ocê, o Condutor escolhe os melhor pra por lá na, mais na frente, né. Eu como num...sempre eu trabalhava de Meiero, né. Tem o Ponteiro, ai na viagem eles fala, dois, cada lado tem o fiador, aí vem o Meeiro, aí vem o Cultero, né. Aí, Sempre trabalha assim, mais ou menos uns sete peão, assim na Comitiva, a maioria. É um Ponteiro, dois Fiador, dois Meeiro, e o Culateiro, que é o Condutor, sempre é , o máximo é 8 assim, e o Cozinheiro.

- E nessa época das viagens você tinha uns quantos anos mais ou menos?

- Ah, eu tinha já, eu tinha uns 18 anos, já.

- E como é que é o pessoal? Eles são bem amigo? Como é que é a relação assim? Tem de tudo? Como é que é?

- É, são tudo amigo, que viaja junto, né. E tem de tudo, tem de tudo pra comer, né. Leva, e faiz, nóis come o memo que come aqui na fazenda, come arroz, feijão, carne e farinha (faiz?) com macarrão. Só pra dormir que é mais difícil, tem lugar que você acha, tem garpão nas fazenda, ocê dorme no garpão, mas tem lugar que não tem, que você dorme de baixo da árvore, que nem o pessoal dorme ali, né? 
- Eu dormi já também assim...

- Então, tem que dormi de baixo duma árvore.

- Efrio?

- Ah, o frio, quando tá frio, você passa um pouco de frio. Se tiver muito frio, se pega e se você tivé meio ruim de coberta, né, você num pode carregá muita mala, roupa, também na Comitiva, aí você pega o pelego e forra debaixo, na rede assim, pra diminui um pouco o frio (... ) (muito som de passarinho, não dá para entender...]

- Tá, então a gente ta falando agora de frio e de calor, e sobre a diferença de fazê, na época da, tanto no frio, no calor, na época da, a diferença da cheia e da seca? Você lembra, às vezes que vocêfez se tava seco? Ou se teve alguma vez que vocêfez e tinha mais água? Como é que era essas dificuldade?

- A seca é mais difícil pra banho pra achá água, já (...) aí no Pantanal, ta tudo seco, que nem agora, tá tudo seco, já é mais difícil pra fazer armoço, o Cozinheiro já tem dificuldade pra achar água e sempre num faiz, só sai de manhã cedo e faz janta, as vezes. Tem lugar que não acha água pra fazer almoço, aí...

- Ah, as vezes pula o almoço?

- Pula, por causo que não tem água

- Nossa!

- Aí você tem que só, talvez se, na Comitiva você não toma chá, chá é o quebra torto de manhã, né, muito difícil, talveiz você vai só janta. Ai talveiz se o Condutor for, meio prático na viagem, mais bom, ele toca mais o gado, encerra mais o gado, mais cedo, pra podê comê mais cedo e num tomô chá num armoçô, vai só jantá.

- E o? Você conhecia, você lembra assim, se for falar que saia de uma fazenda ia pra outra, você lembra o roteiro? Como é que era? Por exemplo, essa que você falou que saiu do Corguinho e foi pra? Como é que era?

- Fomo no São Gabriel, fomo lá no tar do Ariado, lá. (nome de fazenda? Areiado tbem?)

- Você lembra assim, se foi passando dessa fazenda e foi pra essa? Lembra ou não?

- Lá eu não alembro, eu só lembro que nóis passemo na cidade. Eu não conheço bem. Eu passei só essa vez mesmo, com gado lá. E passemo, saimo do Corguinho, passemo no tar do Pequi, uma cidadinha, um patrimoinho, pequenininho assim. Aí desse Pequi nóis fomo ni Camapuã, e na Bandeirante, naquela fazenda, aquela cidade, Bandeirante, aí fomo no, antes de chega ni Camapuã tem uma cidadezinha, também, tar de Chambe e xuga, que chama.

- Como é que é? (Sangue suga?)

- Chamba e xuga, é. É, aí vai, ai nói fomo em Camapuã, em Camapuã que nói fomo e de lá nesse Ariado leva o gado e deixemo na fazenda.

- É mais o Condutor, quem que sabe mais o caminho? Na Comitiva, quem tem que saber mais o caminho?

- É mais o Ponteiro.

- O Ponteiro? 
- É, o Ponteiro que é responsável pelo gado na frente e o Condutor é responsável por tudo, né. O Ponteiro se fala, nóis vamo aqui, você tem que obedecer o Ponteiro, né. Se ele coloca a cara, você tem que ir.

- Se ele errar, todo mundo erra?

- Se ele errar, todo mundo vai errar também, só se o outro, se num conhecê, o outro, passa informação pra ele. Vamo aqui, vamo ali, vai tranquilo.

- Eu penso também no Cozinheiro, porque ele vai sozinho? Num tem ninguém pra perguntar...

- É o Cozinheiro sabe, é por isso que você tem que ter a prática, de mexê, de sabê viajá. O Cozinheiro também tem que sabe conhecê, tem que sabê antes, pra podê cozinhá, pra pode conduzí também o, fazê o cargueiro, encilhá o cargueiro, porque é difícil, num é fácil, encilhá 3 cargueiro, 4 cargueiro, e sai aí, e chega lá você vai ter que desincilhar, fazê o armoço, e depois do armoço, ocê tem que desincilhar de novo os cargueiro pra saí de novo. E é mais difícil já.

- De todas as profissão qual que você acha mais difícil, já?

- Acho que é o Cozinheiro, ne. O Cozinheiro é o que sofre mais, é com chuva, tem que cozinhar, pode tá chovendo, tem que chegar mais cedo no ponto de armoço. Se tivé chovendo ele tem que arma a barraca. E caçá lenha ainda, lenha moiada, pra pode acendê o fogo, fazê o almoço, até o pessoal chegá lá o armoço tem que tá pronto já.

- Você falou pra mim também, uma vez, mas é bom a gente gravar também, pra depois eu passar, da diferença de trabalhá no campo e trabalhá na estrada, você lembra o que cê falou, que um era mais difícil, eu perguntei qual que você acha mais difícil, aí você achava que no campo é mais difícil de trabalhar do que a ...

- É que nem eu tava falando, na viagem você, é todo dia você sabe daquela obrigação sua é só aquele, ocê num tem outra obrigação pra fazê, é só na viagem né. E na fazenda não, você trabaia mais e só que nóis é mais forgado, né. Na comitiva não tem feriado, num tem domingo num tem nada, é direto, né, viajando. E na fazenda, não, na fazenda você levanta cedo, você vai fazê um, você vai pro campo, ou vai fazê uma cerca, ou vai fazê quarqué coisa, e em fazenda, essas fazenda mais grande, não, é mai o dia inteiro no campo, né.

- Vocêfala, você falou que num tem hora pra chegar...

- Numa fazenda grande, você sai cedo e ocê tem hora pra saí, mas pra chegá não. Cê sai 5 horas, talveiz 4 hora, só chega 9 hora, 10 hora da noite de vorta na fazenda. Talveiz leva, aí o capataz manda levá uma farofa procê comê, ou leva uma carne pra assá no campo, você come lá e já passou o dia também, né.

- Na comitva tem um esquema bem certinho?

- Na Comitiva não, na Comitiva você sabe, você vai carculando mais ou meno a hora docê chega ne, você num aperta o gado, você sai que nem, você sai dali da Nossa Senhora do Carmo, você sai pra pousá na Fátima. Você sabe a distância, que é pertinho, cê armoça ali no Cerradinho ou vem armoça aqui já, aí de tarde ocê sorta o gado pra dá um pasto, ai, e mais nada, assim, se é as 6 ocê ta tranquilo já.

- E o gado quando sai no primeiro dia, assim na Comitiva? 
- O gado quando sai na Comitiva você tem que saber sortá ele. Por causo que, por isso que a maioria do pessoal que vai na, tem que ir frente é bem prático pra pode surrá o gado com o arreadô. $\mathrm{O}$ arreadô é importante na Comitiva. Se não tiver arreadô, ocê num, é muito difícil docê viajá, por causo que ocê tem que surrá memo ele assim, pra ele obedecê você, já na saída. Aí conforme voce vai viajando com ele já, segundo, terceiro dia, ele já ta bem obediente, já, você faiz o que você qué com ele. Ai no ponto de armoço você chega, na saída você che... na saída você vai dando o pasto já, né, saiu do mangueiro, já vai, pasta, já. Aí, inté mais ou menos nove horas, por aí, aí o gado já vai andando já, aí o gado já sai pra anda, aí é hora docê anda memo. Se o ponto de armoço tivé meio longe, aí mais ou meno 11 horas, por aí, ocê ta chegando no ponto de armoço, aí você para o gado, arroia o gado, assim, e o gado chega e já para e já deita tudo. Aí ocê pode sai, os 3, 4 e armoçá, fica só um, dois cuidando ali o gado, só. Vai lá, armoça, sorta o cavalo, e vorta aqueles que foi armoçá e o que ficou cuidando vai armoça. Aí vorta. Aí quando é mais ou menos meio dia, uma hora, o gado já sabe que já é hora de sai pra andá, né. Aí já vão levantando e vão levantando, forçando, vai saindo já, né. Aí vai de novo (...)

- E tem um gado que você acha que é mais difícil de trabalhar, de você sai com ele. Algum, por exemplo, se é touro, o que que, qual tipo de gado que...é mais difícil de levá? Tem algum que é mais, ou é tudo igual, não tem diferença?

- Não, o mais difícil de, de conduzir é o garrote, o garrote assim, é, 2 ano, 3 ano assim, o macho, tudo o macho é mais difícil, eles começa um subi no outro assim, e começa, junta aquele bando assim, e vai subindo, vai até derrubá dele. Aquele que vai correndo, começa a cansá e começa a cai, dá mais trabalho. E o gado fêmea não, o gado fêmea é acomodado pra viajá, tanto faz vaca ou novilha, é mais fácil docê conduzí, num tem essa putaria de fíca subindo no outro assim, obedece mais também.

- Evaca parida?

- A vaca parida, aí já é mais difícil com bezerro também, num guenta muito a viagem.

- Fica preocupado mais com a saúde do ...?

- É novinho, sempre tê um, se for mudá o gado duma fazenda pro outro 2, 3 dia, ou uma semana, se tem bastante vaca parida ou bezerro novo, sempre tem que ir um trator, assim, acompanhando. Aí cedo você pega o bezerro põe num trator, assim, numa carreta, faiz um tipo, uma gaiola, numa carreta, aí os maior já vai. Aí chega no ponto de armoço, aí o trator, o tratorista, chega umas bezerra ali, você desce as bezerra pra mamá, os bezerro mama, aí a hora que você vai sai assim, você vai andando e os bezerro já vai ficando pra traiz, aí cês vão pegando os bezerro, pondo na carreta e vai só no pouso, vai mamá novo, deixa pousá com as mãe no mangueiro.

- Você falou do arreador que é importante, aí, é o arreador, o laço também, qué dizê se sai, que mais que é importante ter na Comitiva, assim?

- O laço também, talvez corre uma, uma rêis, assim, uma vaca, ocê tem que laçá ele pra podê vorta, né. E o arreador é o mais importante memo, pra surrá o gado, o gado arrespeita muito, estalô aqui, eles já sabe que é pra para já.

\section{- E o berrante?}

- Ah, o berrante também. O berrante é o Ponteiro que tem que tê. Pra ele aprende também, a hora que o Ponteiro saiu do mangueiro, antes de sair do mangueiro toca o berrante assim, pro gado já, acostumá com o berrante, já vai acostumando, já levanta já, se tá deitado já levanta, que é pra saí. E cada passada de portão assim, se o, se o passador, assim, vai passar o portão, 
o Ponteiro toca o berrante, pra, pro gado já atravessá, e o pessoal já sabe que é pra atravessá ali, a cerca ali. E na encerra também, de tarde, ele toca o berrante e o gado já sai no corredor pra ir pro mangueiro. Talveiz o, é tudo combinado assim, o Ponteiro tocá o berrante pro chama o Fiador do lado, eles toca. Aí o, aquele fiador, de esquerda, que trabalha, já sabe que tá chamando ele pra frente. Se ocê tocá de outro jeito, tem outro toque, ele chama o, que trabalha na direita pra, já sabe já. Então ele, talveiz já ta meio sabendo já na hora, pra andá, toca o berrante o pessoal já sabe que é pra í já pra frente.

- Eé, só o Ponteiro que carrega o berrante?

- Só o Ponteiro que carrega o berrante.

- O pessoal tem aqui a, na fazenda usa mais a buzina, né?

- É, eles usam mais a buzina assim pra rodeá o gado, pra num, talveiz sai pra rodeá o gado no campo.

- Aqui não usa não, né?

- Não.

- Nunca vi usá.

- Teve umas veiz, seu Joãozinho usava, acho que era uma buzina que ele saia.

- Eu nunca vejo eles usarem aqui, engraçado...

- Pra não sai gritando aí eles usam o berrante, o gado pra não deitá. O gado acostuma tocá o berrante assim, toca o berrante assim, já sabe né. Ele vai pará lá no coxo.

- Eu lembro uma vez que eu fui, uma Comitiva lá saindo da Caiman, e tinha um senhor e ele falava assim que, e o seu Zé fala muito isso também, que tem que conversá com ela, pra ela ir conhecendo você.

- É, o gado, ocê conversá, o gado vai acostumando com a pessoa, que tá viajando com ele. Você chega, desce do cavalo, anda, o gado vai, acostuma cocê. E aí vai acostumando com todo mundo já assim, não fica mais com medo de gente, de olhá pra ele. O gado tem muito medo de gente de a pé, né, o cavalo você pode entra no meio dele, fazê quarqué coisa, mas se desce de a pé assim, o gado fica louco.

- E, dificuldade. Nós falamos de trabalhar no campo, as vezes pode ser mais difícil, mas e esse negócio de solidão, de ficar longe da família, se tem mulher, o pessoal sofre um pouco com isso, né?

- Sofre, ah, é mais difícil, pra quem é casado é difícil já, e acostumô com a muié, o filho também, e pra quem é sorteiro, sorteiro num liga pra nada, num tem nada pra, só ele memo e fica mais tranquilo

- Agora quem tem família, filho pequeno...

- Tem que trabaiá, se num trabaiá...

- É, cêis também tão aqui, agora, o Luan tá lá, também mesmo assim.

- Tem que trabaiá, senão o que vai fazê.

- As Comitivas as vezes eu vejo que são muitos dias, né, então é bastante tempo, né?

- É quando ocê pega uma, boiada pra trazê assim bem longe de Comitiva, é, dura uns 40 dia, 50, 60 dias mais ou meno de viagem. 
- E chega, e parece que já sai pra outra, né?

- Chega, e tem muitas gente que já deixa, vai, pega, num para e já vorta fazê ôtra já. Só vai na cidade, fica uns 2, 3 dias, e já vorta pra trás de novo, mais 40 dia de viagem

- E essa coisa de falá que boiadeiro tem dificuldade com bebida, que bebe muito, porque será?

- Ah, isso é normal, o pessoal toma pinga aí, num tem ôtra coisa pra ele tomá, se toma, a primeira coisa que chega num, num buteco assim, num bolicho, é tomá pinga, cerveja, farreá, num tem nada. Já pega o dinhero pra gastá, já, né.

- E gasta tudo?

- Ah, gasta tudo, chega na cidade, a primeira coisa que vai, é estourá dinheiro numa bebida, num liga pra nada, quem tem família não, quem tem família é normal, vai embora pra casa, dá o dinheiro pra muié, que ta precisando lá, mai o sorteiro...

- E a mulherada? Num tem também? Boiadeiro tem fama de sai com a mulherada também?

- Tem, por isso, então.

- Na corrutela?

- Se chega ta passando numa corrutelinha assim, tivé a muierada vai indo, vão lá bagunça, lá, tomá cerveja e fazê uma bagunça memo, durante à noite, né. Isso é, eles gosta de fazê isso.

- É onde também acha, pra tirar um pouco também da solidão da viagem....

- Ainda tá gravando?

- Tá. Pro meu trabalho, tem muita coisa pra eu estudar sobre Comitiva, num tem quase nada, eu fiz pesquisa pra ver o que tem sobre Comitiva, até agora eu tô com um dvd que eu quero mostrar pro Seu Zé, até tava falando pro João, pra fazer aqui, pra mostrar pro pessoal, muito legal, sobre Comitiva, mas foi a única coisa que eu achei, num tem quase nada. Então, tem muita coisa pra estudar, mas se você for estudar, querer estudar tudo, não dá pra escrever no trabalho, então o que eu tô focando é sobre o roteiro. Por isso que eu tava perguntando pra você, é mais o meu trabalho, é pra saber como que as pessoas se localizam, por exemplo, aqui você se localiza bem, você já falou os ponto de referência que é o cerradinho, que é o almoço e ali na Fátima, né.

- É o pouso, é...

- É, essas coisas assim de referência que eu quero saber, que eu tô estudando bastante, mas toda a história também é legal sabê, da sua vida, tudo, eu também vou colocar, mas só aqui, que eu tinha pergunta sobre isso, como é que é o mapa que vai fazendo na cabeça, a pessoa que tá sempre viajando, ela vai tendo um, fazendo um mapa, né, dá...

- Faiz...

- Que nem, você tem aqui do, por exemplo, você vai lá pro corixo fundo, você tem um mapa da que você passa aqui pelo Abobral, passa aqui pela porteira, depois vai pra, sei lá, vai fazendo tudo um mapa na cabeça, e eu tô estudando um pouco disso. Mais uma coisa também que é importante pra eu aprender, é sobre essa diferença da cheia e da seca, como que muda o caminho, aí você falou da dificuldade da seca não tê água, e na cheia, você falou pouco.

- Na cheia, é mai, quanto tá cheio é difícil cê, que nem, se você for pegá um gado aqui na Nhecolândia, quando tivé cheio, então pra atravessá aqui, pra saí em Aquidauana e pro Rio 
Negro, aí, essa região já é mais difícil já, tá muita água, né. E talveiz, pra saí aqui nessa região, na Nossa Senhora do Carmo, ocê vim por aqui, aqui também quando tá cheio já é difícil passá aí também, tem muita água no corixo fundo e já vai mais pelo Japorá e dá mais a vorta por lá, né.

- Por onde que é?

- Pro lado do Japorá, pelo Rio Negro, eles vão dá a vorta, pra saí no aterro, pra pegá o aterro pra vim pra cá, pra saí no Buraco das Piranhas, aí já atrapalha, aqui, por aqui, pra saí pra Senhora do Carmo mais perto tem que dá tudo essa vorta, aí eles vão gastar mais ou menos 5 marchas, 6 marchas a mais e por aqui, não, por aqui deu, sai aqui já na frente, já, mais perto, já. Já tipo, torá um ataio aqui, que eles torá. Sempre o pessoal, quando vai, faiz viagem, já sabe mais ou menos por que caminho que eles vão, já, carcula, nóis vamo passá em tal fazenda, em tal fazenda, em tal fazenda, pra sê mais reto. Que eles num vão ficá dando vorta pra, talveiz dá uma vortona pra saí ali naquele lugar, pertinho, quase mesmo, ali memo, lá embaixo assim.

- Mas isso tudo a ver também, então, com essa coisa da água, né? E portao fechado, pouso caro?

- Tem a ver com a água, se tivesse cheio que nem essa época agora, era muito difícil de tá passando aqui, por causo que tem muito brejo aí, fundo memo, e nada e é muita água, ia andá só n’água aí, uns 3, 4 dias, já, só direto n’água, aí já é mais difícil pra andá. Na seca agora tá passando, cê vê que tá passando carro, direto, tudo aí, tá seco, você não acha água pra nada aí.

- E aconteceu isso, eu fui 3 ou 4 dias, aqui, numa Comitiva que saiu da, do pessoal da Nove de Ouro, saiu aí da Mireta, e eles, a gente encontrou com eles na Estrada Parque e aí eles iam por esse caiminho que você tá falando, iam dá a volta, né, aí o João falou com eles, falou, não, mas se vocês forem por aqui, também era bom, porque eu pegava carona com eles, daqui na Comitiva, né, se for por aqui, mas porque tava bom mesmo, daqui vocês economizam mais, num sei o que, mas eles não queriam muito ir, porque será, eu não entendi muito bem isso, porque que eles num...

- Mas depende onde que eles iam, né,

- Eles iam, a gente foi pra São Carlos, passo tudo essa, Buriti, e eles iam atravessar o, atravessamo o Rio Negro.

- Mas eles iam dá a vorta lá pro Japor... dê certo eles num conheciam por aqui, não sabia chega aí, num tinha informação, de como que tava a estrada aqui, passa aí...

- É, tavam com medo... E as vezes também não confiam assim do João falá, que não conhece muito aí.

- E a maioria eles conhece só por lá, de certo, eles iam dá uma vortona, memo, mas também eu não sei se eles iam em arguma fazenda, mais pra lá e mais pra cá assim, se fosse numa fazenda pra cá, por aqui assim, por isso que eu tava falando, aqui é um ataio, que por lá eles iam dá muita vorta memo, que lá eles iam fazê, essa, uma vorta assim de viagem, se viesse assim, e aqui, eles...

- Por que eles iam atravessá o Taquari.

- Ah então, por isso, que, é por lá também depende onde que eles iam atravessá, sempre eles travessam lá no Porto Rolon, lá que é a travessia, a maioria eles falam Porto Santa Cecília, ali. 
- É porque o duro que nessa estrada também, que é só estrada assim e corredorzão, né, é bom pra levá o gado, se for vê né?

- É bom pra levá o gado porque ocê...

- Éfácil...

- É fácil, mas quando você sai fora, acaba o corredor aí você já tem cada um o seu lugar, né. Cada um puxa, a cabeceira, o fiador, e o meeiro e o culateiro, cada um já vai na sua parte aí, né.

- Mas ali também acho que era um pouco mais difícil de água, na época que a gente foi. Se eles fossem por ali também o gado acho que ia sofrê um pouco mais também?

- De certo saia posava aqui na Fátima, aí pousava na São Ca, aí no, Nossa Senhora do Carmo, aí pousava no São Carlo, pousava no Buriti, acho pousava no Santa Filomena, do jeito que eles iam.

- A gente acabou falhando num retiro lá dá...

- Depois do Buriti?

- É.

- É Santa Onofre.

- É, nossa, que lugar esquisito lá.

- É... é bem... Então, Santo Onofre, aí certo eles iam pousa lá na Santa Filomena, pra í lá no Porto Rolon, lá que é onde que tinha que atravessá, tinha que atravessá o Taquari, aí eles iam no, naquela fazenda lá, na Alegria, aí iam no Manduvi, aí foram no São José, aí foram noutra fazenda lá, é, Providência, aí da Providência acho que eles iam, eles foram lá no Porto, na Santa... é, eles foram na Lurde, da Lurde eles iam no Porto Rolon, dentro do Taquari.

- Como que você sabe tudo isso?

- É, que é a Comitiva, aí é uma rota que se, é reta, eles faiz pra í, num faiz vorta nenhuma, é direto aí.

- É uma reta?

- É uma reta só aí, você pega, vai aí, a única vorta que ocê vai dá é quando você vai inté no Buriti, vorta assim, você anda um pouquinho pra esquerda.

- E você já andou tudo isso aí?

- Já, conheço tudo aí.

- Quando você andou isso aí?

- Trabalhando aí, que nem, nóis saia, talveiz nóis peg... quando eu trabalhava lá no Touro Fosco, numa fazenda lá, aí nóis trazia gado da fazenda, que nois ia ajudá a trabaiá gado, nóis vinha trazê gado aqui pra São Bento, nóis vinha por aqui, nessa região do São Pedro aí. Nóis saia na São Pedro, vinha na, saia depois do almoço da São Pedro, pousava na Guanabara, da Guanabara nóis vinha no Campo Dóro, do Campo Dóro vinha no Manduvi, do Manduvi nói vinha no Cácere, do Cácere nói vinha no Japorá, do Japorá que nóis vinha no São Bento, né. Então por aqui por dentro, por aqui por dentro, quando nói saia lá do, o Tadeu arrendava o Cocar, nóis saia do Cocar vinha na Santa Luzia, da Santa Luzia na São Joaquim, da São Joaquim nóis pousava no Paraíso, do Paraíso nóis vinha na Santa Filomena e da Santa Filomena nois vinha no, passava ali por Santo Onofre e ia no Buriti, do Buriti nói viémo na 
São Carlo, aí viémo aqui, nói passemo aqui, passemo, armocemo aqui na Fátima. Aqui normalmente o pessoal almoça, na Mireta.

- Armocemo na Nossa Senhora do Carmo, vinha pousá aqui na Fátima, que é a ?? Aí no outro dia nói cheguemo aí. Até sempre quando nóis trazia Comitiva de lá, sempre eu vinha na, cozinhando pro pessoal.

- Você vinha cozinhando?

- Vinha cozinhando.

- Ah, não!

- É sempre, mas sabe que sempre eu vinha de trator assim.

- Ah, mas daí é chique demais!

- Aí chegava cedo, saia cedo, lá ...já tava no ponto de armoço há muitas hora, 7 hora, 7 e meia eu tava no ponto de armoço. Enjoava de ficá sozinho lá no ponto de armoço, ficava esperando o pessoal lá, o pessoal chegava tarde lá.

- E o pessoal gostava da sua comida?

- Ah, gostava, comia, não tinha otra.

- A gente viajou com o Tico, uma vez, Nossa Senhora, ele não dessalgava a carne, picava um troço, difícil de comê, hein... e ele foi no carro também, na Comitiva que a gente foi na, no Carandazal, que a gente dormiu, nossa, tinha muito mosquito no Morro do Azeite, Deus me livre...

- Ah, você viajou no trator, de trator, você dá pra levar lenha, você levar água, assim...

- Isso que é bom, né?

- Assim que é bom, bastante, chega lá tem que ficá catando lenha lá, no ponto de armoço, ou no pouso, já leva tudo no trator já, é mais tranquilo.

- O Cozinheiro as vezes vai de trator, vai de carro, que mais tem, tem carroça alguma coisa assim?

- É mais é no cargueiro.

- No cargueiro, é mais assim.

- E tem argum também que tem na carroça, mas a carroça já é mais difícil já, já é mais pesada pra por um burro sozinho pra puxá, mais é no cargueiro. Mais no cargueiro.

- E a última parte do meu trabalho, que eu tô estudando, é sobre as mudança que tão acontencendo ans Comitivas. O que que tá mudando de sei lá, 50 anos pra cá, de 20 anos pra cá, ou de 10 anos pra cá? Que que tá mudando, você acha que tá mudando alguma coisa na Comitiva? Você vê diferença de quando era moço e fazia Comitiva, de escutá comentário, de agora, ou continua a mesma coisa? O que você acha? Se aqui no Pantanal é a mesma coisa?

- Eu acho que é a mema coisa, não mudou, diz que, quase nada, só mudou o pessoal só, só vai mudando o pessoal, né, mas acho que, os Condutor também vai mudando, argum é bão, argum não, mas acho que é a mema coisa, e vai acabando o pessoal que é prático também, né.

- Vai acabando, você acha?

- Vai, cum, a maioria já é novo já né, só se for, aquela pessoa que gosta memo de mexer só com viagem, aí aprende a mexer com viagem, sabe, entende, né, e esse já, argum é bom, 
argum é ruim, é difícil cê trabaia cum, se ocê pegá 2,3 prático, e o resto, mais 2, 4 que num é prático, já é difícil trabalhar já, né. Agora você pegando um pessoal tudo pareio, prático, num tem dificuldade em nada, você vai, tranquilo. Você sabe que cada um vai fazê a sua parte, né. Agora, talveiz, se tem 2, 3 prático, o resto num é prático, aí já, você tem que fazer a sua parte e ajudá o outro a fazê, e assim vira uma bagunça, né.

- Que que é ser bom pra ser boiadeiro, você vai falar, alguns são bom, outros são ruim, que que é ser bom?

- É você entendê da viagem, né. Você sabê viajá, você tem que sabê, sê prático, que nem eu tava fala.., prático, sé é a mema coisa, ocê trabalhá numa fazenda, procê sê, ocê trabaiá de peão, ocê tem que sê bão, bão, ocê tem que sê um peão compreto, sê, aonde o capataz falá pra você, você tem que fazê tal serviço, você vai lá e faiz o serviço, né. Ocê dá conta de fazê, talveiz cê num pode sê bão pra laçá, num pode sê bão pra segurá pulo, mas você sendo prático do serviço, isso que importa, né.

- Na, e pra boiadeá, que que é precisa se bom assim, pra, no dia a dia que que precisa saber?

- Você sabê conduzi o gado, né, sabê fazê sua parte, num, na viagem não é só pegá o gado e ir empurrando o gado, cê deixá o gado pastá, um pouco assim, ocê sabe mais ou menos a hora que o gado for abrindo um pouco assim, você vai lá e joga o gado um pouquinho pro lado do Ponteiro assim, o gado já sabe, vai virando já, num dexá ele abri muito assim, tem muita gente que não sabe, ele, o gado vai pastando e vai folgando, assim quando você vê o gado já esparramô tudo aí. Já é mais difícil procê...

- Não vai tomá tereré...

- É, talveiz já fica amontuado assim, já fica 2, 3 junto, já, pra, tomando tereré, assim, isso aí o Condutor prático já fica só olhando você, fala, ah, aquele peão só gosta de ficá muito amuntuado e já num cuida da culatra (...). Talveiz ele num ensina o gado a andá bem, aí o gado só teima praquele lado lá, pro lado do cara prático, aquele lado ele num teima muito, porque sabe que o cara... Aí ele teima, fia só prum lado, aí o ôtro, talveiz um prático vai e o outro, talveiz o Fiador é prático, o Meeiro num é prático, o gado forcéja bastante, aí sofre os dois, já.

- E apertá muito também, né?

- E apertá muito também...

- E então, com algumas pessoas que eu conversei, é alguma coisa que eles não querem mais, trabalhar de boiadeiro, a pessoa não qué mais trabalhar de boiadeiro, porque será isso?

- Então, é mai difícil, é um serviço muito chato, sofrido memo, sofrido, é ocê toma chuva, talveiz cê chega num ponto de armoço, tá chuvendo, num tem garpão, ocê tem que durmí ali, por isso que ocê já tem que sair preparado na viagem. Tudo que tem, que viaja direto tem aquela torda, né, uma torda que põe em cima da rede, assim, uma lona. Cê chegô, o boiadero chegô, primeira coisa que ele desincilhô o burro, a primeira coisa que ele vai caçá armadô de rede já, chega ali, se tivé meio com o tempo ruim, cê já arma a sua torda e amarra sua rede lá de baixo. Aí pode, se tivé de chovê pode chovê, cê num, aqueles peão que num tem prática de viagem, já num leva, aí cê tem que depende lá do Cozinhero, porque o Cozinheiro já faz a barraca dele lá, com a cozinha, e quem tem direito de durmi lá, debaixo da barraca é só o Cozinheiro, que tá cuidando ali, cê sendo amigo do Cozinheiro, ele deixa cê durmi lá, senão cê vai sofrê lá, na chuva, móia e frio também, e é assim.

- É só isso... 


\section{ENTREVISTA III}

\section{Luis Martins (Biguá)}

- Entrevista realizada em Agosto de 2009, no ponto de parada da Fazenda Nossa Senhora do Carmo. Corumbá-MS. Como este Cozinheiro ficou neste ponto por 3 dias, houve tempo de rever algumas das dúvidas surgidas na primeira entrevista. ${ }^{130}$

- Biguá é Cozinheiro de Comitiva há cerca de 40 anos. Tem este apelido por ter nascido na beira do Taquari.

- Apelido? Biguá

- Idade? 48 anos

- Escolaridade? muito pouco

- Religião? Católico

- Família? Um guri, com 10 anos e três meninas com 15, 11 e 6 anos.

- Onde nasceu, sempre morou no pantanal? Corumbá. Fazenda Santa do Virgem, beira do Taquari. Dono Maneco Mourão. (família mora em Campo Grande).

- É pantaneiro? Sim, legítimo.

- Pai e mãe de onde? Mãe é de Ponta Porã e Pai é de Cuiabá

- Com quem aprendeu a trabalhar? Pai? O pai era capataz, aprendeu serviço de fazenda, também fazia viagem, mas não viajou com pai. (começou a viajar com quem?)

- Onde começou a trabalhar? Fazenda Buriti

- Qual era a posição na Comitiva? Culatra, Fiador

- Não era o dinheiro que era mais fácil, era o serviço que tinha mais. Tinha mais boiada para puxar, hoje em dia é o serviço que tá difícil. Leva aí 10 ou 15 dias já embarca ela, antes viajava 40 ou 50 tirava tava com outro serviço na mão. Ás vezes o condutor nem entregava aquela boiada lá e já tava com outra boiada pega já. Embarcava a tropa lá, as veiz viajava 7 ou 8 mes de serviço. Agora hoje em dia não, hoje em dia você fica 10 ou 15 dias parado, as veiz até 20 .

- O senhor nasceu na fazenda ou nasceu na cidade?

- Na fazenda.

O seu filho tem vontade de viajar?

Ah tem, tem vontade de viajar né.

O senhor pensa em ensinar o trabalho para ele?

- Penso que não né, porque vai ficar muito difícil .

- (...) acho que não, porque é muito bom. O senhor tem religião?

\footnotetext{
${ }^{130}$ No início da entrevista havia muita interferência externa (sons de aves) e o aúdio ficou um pouco comprometido.
} 
- Católico. Penso eu, eu trabaiei com um fazendeiro aqui (...), se formo tudo, mas não sabe nada, eles embanana tudo. Ele falou que sabe ler, mas ele num tem a prática né? Aqui memo essa tropa que nós trouxemos aí (...) nóis que temos que tirar de tudo.

- Quero saber um pouco historia da sua vida e como começou com as Comitivas, que você me conte um pouco das comitivas...como é...

- Então, eu morei uma média de uns doze ano lá, aí eu já subi a Serra com um condutor, aí eu já grupei numa Comitiva. Meu pai era caminhoneiro, minha mãe era largou do meu pai quando eu era pequeno.

- Conhece bastante sobre Comitivas, então o que é uma Comitiva, como é? Você já trabalhava de cozinhiero...

- Foi assim ó, eu trabalhava na estrada tinha um punhado de tempo já, viajava, ele perguntou pra mim se eu não pegava a cozinha. Peguei a cozinha e levei até o fim, fartava uns (...) todo mundo da boiada. Antigamente eu gostava mais sabe, era mais novo, gostava mais.

É uma novilhada, ta fechada no mangueiro aí. Você conhece a São Carlos aqui, né?

- O senhor viaja mais no trator ou no cargueiro?

- Cargueiro. É... É difícil o fazendeiro que põe o trator né, não é todo fazendeiro.

- É porque gasta. O senhor conhece o Celsinho Guimarães?

- É porque ta muito seco, não tinha água, aí judia. Se eu te contar uma história, tem uma reportagem dele no DVD.

- Ahé?

- Eu conheço o Celsinho, ele é lá de Corumbá né. Queria até encontrar ele para falar dele...

- Eu queria marcar um dia, pra conversar com ele também, mas a gente não achou mais ele, acho que ele entrou aqui pro lado da fazenda.

- É, ele cruza muito.

- Ele vai de carro também.

- É, ele tem uma caminhoneta, quando ele chega aqui no pé da serra aqui ó, judia, judia, é muito asfalto demais.

- O senhor já ouviu falar de leva cansado?

- Já. É o corredor, os Meeiro vai pra tráis e os fiador vai pra frente, né. Tem gente que gosta né.

- Então tá.

- Algumas coisas, tem prática, moleque né. Depois que eu comecei a viajar né, eu sempre viajei. Cê acorda cerca de 4 hora. Você levanta de madrugadão né. Ah quando você ta viajando por exempro, para você levantar e (...) tem companheiro que já fala para você, ô cumpadre você vai pegar malhada, o que você vai fazer? (risos) Tá levantando numa hora dessa, né (risos). Tem muito condutor que não gosta, né, aí você escolhe uma hora aí, 4 e meia, 5 horas né. É um horário bom, levanta e não atrasa né, se tive mexendo com cargueiro, a média de levantar é 4 porque aí dá tempo de você fazer tudo tranqüilo né. Aí você já faz (...) a comida que sobra da janta, você esquenta, os companheiro trata a comida que se chama véio esta comida, e quando está quente você já, vem pra cá companheiro, vem pegá o veio, aí come ali, lava a panela, faz tudo com calma. Levanta naquele horário, chegou naquele horário o 
corpo da gente já pede para levantar né. Acostuma a gente, o cozinheiro né, cozinheiro ali, quando vê já tá todo mundo ali, o tropeiro já encosta a tropa e vai embora, tem até 3 cargueiro. A média (...) todo mundo também já não é bom, às vezes atrapalha né. Tem uns pontos certo. Assim mesmo que você vai bater (...). É que você já conhece né, de fazenda em fazenda, pegando os ponto certo.

- Aí o senhor começa a fazer o almoço?

- É. 8 ou 9 horas, essa é a média. Tem que fazer o que é mais difícil primeiro. Uma carne com macarrão, o arroz é rápido né, depois com o movimento, você fritô o arroz, já põe a água ali, a hora que a turma chega para armoçá, o arroz já tá, tá tudo pronto. De tarde a hora que eu acendê o fogo, já vou fazer o café a hora que eu começo a fazer a comida o feijão já ta cozinhando.

- Aí o senhor já faz de novo?

- Aí lavo todas as vasilha de noite, aí já encaixoto, cedo a turma toma o café, aí eu já guardo as vasilha, se lavá cedo, mas cedo atrapalha a gente.

- E o senhor começa que horas a fazer a...

- A turma dorme cedo né, acostuma. Não, tem Comitiva que tem rádio, aqui não tem rádio, mas nóis tamo quebrado dessa vez, dessa vez num tem.

- E bebida, o pessoal bebe muito?

- Bebe, passa em beira de corrutela por aí bebe toma viu. Tem turma que já bebe descontrolado, mas tem turma que é boa, que tá com a boiada, tá de serviço né bebe um tanto, outros que num acha serviço, porque tá ruim, quando acha pinga, já bebe tudo. Otro bebe uns gole e já quer ir embora né.

- Esse pessoal que tem muito dinheiro gasta tudo?

- Gasta. Tem muito companheiro que o que ganha na estrada fica na estrada mesmo, esperando a gente. É ruim, mas a lida da gente é essa né, tem que...

- Uma légua é quanto?

- É 12 quilometro.

- E tem diferença quando fala comitiva de fazenda?

- Tem diferença.

- O que é a comitiva de fazenda?

- A comitiva de fazenda, assim, sempre ela é mais bagunçada né.

- É o pessoal que trabalha na fazenda que viaja?

- É. Chega sem camisa, sem chapéu, mas tem que ter que ter regulamento né.

- E mala de garupa? Quando viaja, e mala de garupa, como é que fala?

- Mala de garupa é diferente do nosso né. O nosso é dobro, né, os pantaneiro usa mala de garupa né, é um porta-capa assim.

- E pitoca?

- Pitoca que eu sei é uma viagem bem curtinha. Suja baxero, né, é uma pitoquinha que eles falam né. 


\section{- Suja baxero?}

- É, porque conforme a situação que a gente tá, tem uns companheiros que nem, cê, vai só sujá baxero, num dá nada.

- E perigosa, também fala?

- É a mesma coisa, perigosa é quando é uma viagem meio nojenta de fazê, né.

- Por causa do gado que não é muito bom de viajar? Quando sai o primeiro dia da comitiva tem que ir se acostumando né? É diferente de quando sai e depois que ela pega batida?.

- É. O primeiro é um negócio mais, meio (...), o gado ta despareio, o gado já vai madrinhando também, já madrinha, já pareia (...).

- Aquidauana tem muita comitiva que puxa boi só aqui memo, né. Só leva só até no pé da serra e não pisa no cascalho, né. Só puxa até embarcá e já vorta pra trás.

- E tem um gado que você acha que é mais difícil de trabalhar?

- Ah tem, né, tem boiada que é mais difícil. Ela é mais braba, né, ela é, já tem outras boiada que já é mais mansa, ela madrinha mais rápido.

- É mais o touro é mais a vaca. Qual que é?

- Ah, não, cê fala a rês, né?

- A rês, é.

- É, sempre o touro é mais cabuloso pra tocá ele, que ele é mais vagaroso, se apertá ele já zanga, né. Já rápido, ele num qué anda, né, é mais pesado. O touro é mais cabuloso.

- E o garrote?

- Não, o garrote não. O garrote é uma das rêis, bem dizê, mais fácil, o garrote e a novilha é mais fácil né, ele madrinha mais rápido, né. É gado novo, né, o gado novo geralmente, ele... o gado mais difícil de mexer com ele é o touro véio e vaca, vaca véia boiadera. Vaca boiadeira num madrinha, ela é igual a égua. Amanhece o dia cantando, já né. É o dia inteiro ocê surrando ela e ela não pega passo. Uma boiada de 1.000 vaca aí, você trabalha o dia inteiro, é o dia inteiro na larga assim, ocê trabalha o dia inteiro. É a mesma coisa que tocá um rebanho de égua, hmm... a bicha é desmiolada. Agora o boi, o boi castrado, o garrote e a novilha é um gado bom de mexê, que é madrinhado né.. Um gado que ocê com três, quatro dias ele madrinha com a tropa, você tocou o berrante, ele levanta a cabeça e vai embora.

- O que é muito importante para levar na comitiva, que não dá para esquecer, tem que carregar?Berrante por exemplo?

- Ah o berrante, esse aí, se deixar já fica bem esquisito já na Comitiva, sem o berrante não tem como né.

\section{- A arreador também?}

- Ah, o arreador é o necessário, né. O arreador, o berrante, esse aí é o essencial, né. Isso tudo faz parte da viagem, né, o berrante, arreador, o cantil, se o peão não tiver um cantil, também, ele tá enrolado. Torda né, se não tiver uma torda...

- A torda é a lona?

- A torda é a lona, a lona 3 por 4, uma loninha 3 por 4. Cada um peão tem uma, né uma loninha $3 \times 4$, ali é a casa dele, né. Chegou de tarde já arma ela. 
- Com chuva... E o peão chama boiadeiro, vaqueiro, chama vaqueiro também?

- É, o vaqueiro depende da região né. O vaqueiro na nossa língua aqui é quando é um peão muito bom né. Aí fala, aquele fulano ali é um peão vaqueiro, é um peão compreto, um cara bom, né, um peão vaqueiro. Mas aqui quase, aqui nessa região nossa vaqueiro, quase num, vaqueiro assim, é mais pro lado do nordeste.

- Na comitiva quem tem que saber o caminho é o Ponteiro e o...

- O cozinheiro.

- $O$ cozinheiro.

- Geralmente todo mundo sabe né, mas o Ponteiro, ele tem que sabê as dobradas, porque senão ele tá enrolado.

- O cozinheiro também chama de cuca?

- Cuca, tem gente que chama Cuca, né.

- Como é que é?

- Mão pelada também. Por que, por causa do mão pelada, das labaredas que queima os cabelo da mão da gente.

- E comissário, fala também?

- Comissário é o condutor, né.

- Ah, comissário é o condutor.

- Comissário da boiada né. Tem gente que trata de Comissário, né

- Eu já perguntei como é que é a solidão...

- A solidão é difícil de aguentá ela, mas a gente tem que ir pra frente, né...

- Tem que trabalhar né?

- Tem que trabalhar. 40 dias parece que passa voando (risos).

- Antes quando o senhor começou a viajar, faz tempo que o senhor viaja, o boiadeiro comprava gado também, ou faz muito tempo?

- Não, o que compra o gado, o boiadeiro que nóis fala é o dono do gado, sabe, ele é o boiadeiro. Ele vai apartá uma boiada numa fazenda aí, ele é o boiadeiro. Por exemplo, chego um boiadeiro, ele vai apartá uma boiada, né, é o cara que compra a boiada, né, é o boiadeiro Nóis somo boiadeiros também porque nóis toca a boiada, a gente leva ela, né. Então nóis somo os boiadeiro né. E o condutor é o que vai conduzir.

- Mas, antigamente não tinha os condutores que tinham a boiada que compravam gado?

- É, mas isso antigamente, né.

- É, antigamente, muito tempo atrás então.

- Antigamente tinha muito boiadeiro que saia comprando.

- Nessa época já era...

- Já tinha boiadeiro que já descia com o touro. Antigamente nessas fazenda aqui do Pantanal quando descia com uma tourada para vender e eles trocava a troco de gado, as vacas véias, 
boiada, e tal. Trocava os touro, por exemplo, eles desciam com 200 touros e aí ocê subia com quase uma boiada né. Trocava daqui pra cá quando tinha, pegava uma torada nelore, era novidade para os fazendeiro, que era só boizinho crioulo deles, mesmo, né, então, o povo que vinha de Minas, vinha de São Paulo, trazia muita boiada, muito bom, aí os fazendeiro trocavam, né. E aí eles vortavam, vortava com muita boiada, né. Então tinha boiadeiro que trocava touro a troco de vaca. Aí eles falava toureiro né, toureiro, descia os toreiro, aí eles trocava, marretava vaca véia a troco de touro, toruno véio.

- E senhor falou também, chega e já sai para outra né?

- Ah já sai, o máximo é... hoje em dia não, hoje em dia já para mais um pouco, às vezes para até 15 dias, até 15 dias a gente pára. Mas antigamente não, antigamente cê chegava com uma viagem, uma viagem e já saia para outra né.

- Quanto tempo de viagem o senhor faz com uma comitiva? O máximo de tempo que chega de viagem.

- Hoje em dia o máximo é 35, 40 dias, né. Dá para contar as firmas que viajam 40 dias, Expresso, Nova de Ouro, eles ainda tem essas viagens de 40 dias, 60, às vezes dá 70 dias, mas você fica trabalhando na fazenda, né, até ajeitar a boiada. Dá 60 dias contando com os dia tudo, né. Antigamente não, antigamente embarcava a tropa lá, desembarcava no pé da serra aqui, saia do outro lado do Paiaguás, lá, pegava uma boiada, levava para Naviraí, aí, Vinhena pra lá. Aí andava era 70, 80, né, andado, né. Agora, hoje em dia não, você vem aqui, trabalha na fazenda, cê fica 15 dias parado aqui, aí quando ocê vai sair para andá com a boiada, as veiz ocê viaja um mês só com a boiada. Aí inclui todos aqueles dias, as veiz dá 60 dias, 70 dias, mas tem os dias que você fica parado né. Antigamente, não, antigamente cê chegava, pegava a boiada pronta ali no mangueiro, andava 60, 80 dias com ela, tocando ela. Hoje em dia ta difícil, é muito difícil, é raro memo.

- E qual a diferença que o senhor acha de fazer na cheia e na seca. Como é que uma comitiva na cheia, os cuidados...

- Ah, ela tem mais dificuldade.

- Na cheia?

- É, na cheia. O Pantanal é, ele ingrato nos dois lados, né, tanto na seca quanto na... O Pantanal, ele é bom agora, de agora até três meses, uns dois meses para frente. Agora nós vamos entrar setembro, outubro, novembro, né, uns três meis ele tá bom de viajá. Porque agora vai começar a chover, vai juntá água nas baixadas. Junta água nas baixadas e você tem água para fazer almoço, para o gado beber, e fica bom, não tem corixo pra moiá a traia, pra nadá, nem nada. Mais aí passou pra frente aí, já começa a alagá tudo e fica difícil. (...) Você trabalha tudo, mas tem dificuldade, já demora mais para você andar aí, do que se andá no seco, demora (...) para andar aí.

\section{- O senhor acha pior na cheia então?}

- Ah, na cheia, na cheia é pior, gado sente muito, a tropa, cê trabalhaia dobrado, traia tudo moiado, apodrece tuda a traia, gado sente muito.

- Um moço falou para mim, eu não sei se faz (...), o senhor já viu ter que andar para procurar água de precisar usar algum graveto pra procurar água?

- O povo tem essa lenda aí, mas eu mesmo nunca usei. O povo fala que com uma arame, um pedacinho de arame, ocê com um pedaço de arame, cê testa ali, esta, nesses pé de piúva, tem 
esses pé de piúva pantaneira, com um pedaço de arame ocê testa água, se tiver água tiver perto, diz que o arame mexe. Para mim isso é uma lenda, né.

- Você nunca testou para ver se funcionava?

- Eu nunca tentei.

- Mas aqui tem água também.

- Aqui tem.

- Nunca passou necessidade de água?

- Já passemo, já vixi, já nesse viajemo nesse Pantanal seco, aí de fazer buraco assim chega nessas baixada, por exemplo, para ver se tem um poço de água. Aí cê chega naqueles poço, a água tá, num tem como cê usá ela. Então cê faiz um buraco, assim num costado, pertinho da água, se a água tá aqui, aí cê faiz um buraco aqui, pra aquela água vim, passá pra esse outro aqui, mas por baixo do chão, né. Ela, memo que ela venha suja, ela vem mais filtrada do que aquela água lá. Memo que ocê côa ela, ela tá terrível, não dá para cê usá, então cê faz um buraco aqui ela já vem por debaixo do chão e dá para usar, vem melhor, vem mais filtrada. Mas é duro, o Pantanal aí, quando seco ele é terrível.

- Sabe que aqui na Pousada Xaraés, faz 8 anos que o João tá aqui e ele nunca viu secar este poço. Tava falando com o pessoal que morou aqui bastante tempo, e agora teve que procurar um poço, outro ali do lado, secou mesmo.

- Não, esse ano foi terrível a seca, porque aqui na São Carlos, aquela baía que tem na frente da São Carlos aí, aquela baía nunca ficou no estado que tá agora, nunca. Tem um poço lá que tá bem no, quase no meio dela assim, aquele poço ninguém sabia daquele poço. Ela já teve seca, de certo, mas muitos ano atrás, que fizeram aquele poço, ninguém sabia daquele poço, agora que secô ela apareceu, aquele poço lá no meio dela. Esse povo que é dono daí, muitos ano que eles são dono dela, diz que nunca viu, esse poço lá. Agora seco, agora tá sem nenhum... Aquela baía nunca fico nesse estado. Qué dizê que a seca esse ano foi terrível.

- Um cozinheiro falou uma vez para mim que não pode jogar água no fogo para apagar, que faz mal, que dá dor nas costa, é uma tradição que tem.

- O povo tem essa.... esse respeito, é negócio de antiguidade, eu já não sou muito desse lado não.

- Não liga muito?

- Pra mim talvez, se dá a gente não sabe também né, a gente não presta atenção. Que o povo, antigamente era mais assim, né, vivia muito pela, prestando atenção nas coisas, né, mudança de tempo, essas coisas assim, né. E até para levantá, levantava pela estrela, estrela Dalva, estrela Boiadeira, que eles falava assim, né. O povo antigo sempre de madrugada levantava pela estrela. Então tem esse negócio também de jogá água no fogo, dá não sei o que, não sei o que.

- Mas o senhor já ouviu falar também?

- Já, já ouvi falar. É... mas sempre ocê usa, porque nessa seca braba ocê não dá pra deixá o fogo assim, sempre apaga. Nunca prestei atenção, talvez até dá dor nas costas, a gente não presta atenção.

- Da estrela Dalva acorda dá pra enxergar, como é que é? 
- É, quatro hora ela sai, então o pessoal que levanta madrugada levanta por ela né. Ela tá numa altura no céu assim, aí se ela ta naquela altura, assim, cê carcula ali, fala tá no horário, ah, tá no horário, são tantas horas.

- E isso dá certo?

- Ah, funciona, né.

- Bem bacana.

- As veiz, quatro horas, ela ta mais ou menos numa altura pra cima do garpão ali, e pode levantá que é quatro hora, quatro e meia. E a estrela Dalva é a estrela Boiadeira, que a gente sempre levanta por ela né.

- E agora quando viaja o senhor tem que abrir os portões da fazenda, porque o pessoal anda entrando, muita gente de fora.

- Tem.

- E eles fecham o portão, faz corredor também?

- Ah tem muita mudança. Nesses lugar que as fazenda é dos paulistas teve muita mudança né... É o corredor, o tratamento é diferente, não é como os antigos daqui, memo do Pantanal. Você chega até o tratamento é diferente né, já não é como, a gente ta acostumado a viajar aqui, conhece todo mundo aí, mas você chega na fazenda que é povo estranho, de fora, já nota a diferença né.

- E tranca o portão às vezes?

- Não, trancar não tranca, mas já não é já, não tem mais aquela liberdade, que tem né. Quando você chegava na fazenda a entrada era aqui, agora muda para outro rumo, já põe mais dificuldade pro boiadeiro. As veiz manda passá lá longe, tem muito fazendeiro que fala que boiadeiro é bagunceiro, que isso, que aquilo, mas não é assim não, vai muito é, isso é muito, sei lá...

\section{- E pagar pelo pouso? Paga tudo?}

- Paga, geralmente tem muitos aqui que pagam. Só se tiver um (...). Por exemplo, tem umas que, que nem aquele povo da Caiman aqui, aí não paga, tem uma fazenda deles aqui (...), aí não paga. Mas tem muitas fazendas que não tem, não sei se ainda tem leilão, se acabô (...), aí tem a rota do leilão aqui que vai para o Paiaguás, aí é uma média de 60 reais o pouso, o pouso aí, é pouso por pouso. Tem muito boiadeiro que nem viaja na rota deles, porque tem a rota deles de viajar, do leilão. Tem muito boiadeiro que as veiz, vai mais pelo centro do Pantanal para não passar no batidão deles que é cruel, cobra mesmo, é 50, 60, 40.

- Mas paga o que?

- Por pouso. Por exemplo, cê pousa essa noite aqui, amanhã cê vai acertar com o capataz lá.

- E sempre que o senhor viajou viu isso ou é uma coisa recente, de agora?

- Não, esse negócio de 50 reais é um tempo pra cá. Antigamente, uns 8 ou 9 anos quase ninguém cobrava. E tinha muitos que cobrava, mas era um precinho só pra dizer que cobrou né. Aqui embaixo no Pantanal, porque pegou o pé da serra aí, onde tem pouso de boiada, eles cobram, tudo cobram. Só lugar que tem ronda, lugar que tem ronda, aí não cobra.

- E pra fazer travessi de rio também cobra, né?

- Cobra. 
- Sabe quanto foi que cobra?

- Última vez que eu atravessei no rio Taquari, lá no Porto de Santa Luzia, lá, acho que foi 1000, eles cobram por cabeça né, dá uma média de dois, dois e cinqüenta por cabeça, acho que é média de dois e cinquenta.

- Mais aí é o dono da boiada que paga?

- É o dono da boiada que paga. O condutor paga só a tropa, só a travessia da tropa, a tropa é separada, né.

- Ah, ele paga a travessia da tropa?

- A não ser que, as veiz o combinado, as veiz combina com o dono da boiada.

- Ah, depende.

- É... Caminhão, essas coisa, assim, por exemplo, se sua tropa tá lá em tal lugar assim, e você vai pegar uma boiada aí você já combina com o dono da boiada. Aí o dono da boiada vai lá, pega sua tropa, leva na onde tá a boiada, aí ele dá o caminhão, dá a vaca, que é matula, né, aí já fica incluído no serviço né, mais aí no causo ele paga mais pouca marcha, né, que ele já deu o caminhão, deu a vaca gorda, né. Aí quando fica tudo com o condutor, comprar a vaca e pagar o caminhão, ele cobra mais caro a marcha, né. Aí quando é o fazendeiro que dá o caminhão e a vaca aí sempre é mais barato a marcha, paga menos né.

- O condutor paga o pouso também?

- É o condutor, o pouso é o condutor, fica por conta do condutor. Aqui embaixo não tem como, aqui tem que pagar. Aí depois que você subir a serra tem muito lugar que não precisa pagar, tem muita ronda, né, eles tem corda né. Já tem uns lugar, cê finca os pau, tem lugar que já tem uns pau de arame, arame veio ou faz a ronda. Aí chego já tá pronto, mas tem lugar que não tem, aí tem que sê corda, tem dois mil metro de corda, corda de naylon, aí chega finca os pau, traz o mangueiro ali, pousa na ronda, aí não paga. Agora, aqui em baixo não tem como, tem que pagá, de fazenda em fazenda.

- Tem alguma história que o senhor lembra pra falar, que é curiosa, tem alguma que eu não perguntei?

- Não tem viu.

- Alguma coisa engraçada que o senhor lembra?

- Chega na hora a gente até esquece, né. Ter, tem muita história (risos).

- Deve ter muita né? O senhor sabe da fazenda Capão Verde?

- A fazenda do Sr. Norberto Braulio. É aqui perto de Tonai?

- Fica perto da fazenda Pequi?

- É isso mesmo.

- Dizem que tem um galpão mal assombrado lá.

- Já ouvi falar, já. O pessoal fala que é assombrado lá. Tem lugar que a pessoa vai, arma a rede ali e chega umas horas da noite e manda mudar e tal. Tem essa lenda que o povo fala né. Mas graças a Deus nunca aconteceu comigo.

- O senhor já pousou lá? 
- Já pousei lá.

- Mas o pessoal costuma pedir licença, o senhor não liga muito?

- É, eu não, mas também eu não duvido, né, tem nego que é debochado né, debocha e tal, inda insiste em dormir lá e é melhor respeitar.

- Mas dizem que o lugar desvia um pouco. Encurta mais ou encomprida mais para não pousar lá?

- É, tem também, mas é difícil né. Geralmente, hoje em dia muito pouco lugar que pousa assim em fazenda, como já tem lugar que nem esse aqui, já num, nego já não vai no garpão não.

\section{- E tem muita história de assombração na fazenda por aí?}

- Hoje em dia não tá tendo mais não, mas antigamente tinha, esses boiadeiro mais antigos fala, conta que o lugar é mal assombrado aí, chega de noite ocê escuta o peão raspando a espora, e tal, chega o tinir da argola, ocê escuta animal bufando, (...) o animal fica respirando, as pessoas escuta até a respiração do animal. Aí cê levanta pra oiá, cê num vê nada (risos). Escuta o cara arrastando a espora, mas hoje em dia, tá difícil isso aí.

- O que mais o senhor acha que é a verdade da vida do boiadeiro?

- O que eu acho que devia ter, é que nem eu falei pra senhora assim, né. Acompanhasse, por exemplo, pegar um condutor que vai levá uma boiada para levar lá no Paiaguá, pra lá, né, aí você faz uma reportagem compreta, né.

- A viagem inteira?

- É. Pega aquele que tem 4 cargueiro, aí você faz a reportagem completa, aí que eu falo que você pega a realidade. Porque tem muita gente que pega assim, vai cortado, não companha do começo ao fim. Que nem o Almir Sater fez, uma vez ele fez aqui, logo que ele tava começando, ele não tinha feito novela, finado (...), fazendeiro muito antigo que tinha aqui, duas comitivas aqui no Pantanal, era um dos pioneiro aqui dessa região. Ele morreu esses tempo. Então ele fez uma reportagem, tava com uma carreta de boi, tava acompanhando a comitiva né, 4 cargueiro, a turma dele, a equipe dele tava no carro de boi. Mas não foi do começo ao fim. Eu, no meu dizer, para fazer uma reportagem completa, pra ficar boa memo tinha que ser do começo ao fim, porque alí você ta ali, junto. Junto com a turma, todo momento você ta junto com a turma. Tem o gravador, filma tudo, filma o dia inteiro, mas pegar esses, o melhor momento né. Aí, acho que fica um reportagem compreta.

- Eu queria fazer isso, mas fui cair do cavalo, aí...

- E outra, pegar uma comitiva boa, uma comitiva pareia, uma turma, uma peãonada bem boa, aí sai. Eu já vi filmar aí, mas...

- Mas é só uns trechos né?

- Só uns trechos, umas turma despareio...

- Esse senhor o Sr. Erom, ele disse que pra acompanhar inteira fica difícil transportar a câmera, o tempo todo.

- É, fazer uma reportagem bem, uma cobertura bem completa, boa é difícil.

- Aí pega só uns pedaços né. 
- Tem que ter uma caminhonete, que agora que tá seco, talvez até dá. Esse DVD que eu tenho lá que é do seu Alcino, eles filmaram mais foi de avião, por isso que cortaram. Filmaram na saída da fazenda, filmaram no rio Taquari, aqui na travessia, no Porto Rolon, no cruzamento de Aquidauana, de Dourados, e lá no dia da entrega da boiada, embarcando a tropa pra vim embora. Então foi cortado, não foi completo. Era bastante boi, era 1.200 boi, parece.

- Nossa.

- Boiada boa, de 4 ano.

- E se agente for desenhar aqui, o senhor deve ter todo o caminho na cabeça, um mapa.

- Ah, tem, tem, fazenda, por exemplo, daqui lá, onde nóis saimo pra levá, eu sei tudinho.

- Você sabe?

- Eu sei.

- O senhor vai falando e eu vou colocando aqui, ta? Vocês saíram da?

- Fazenda São Carlos.

- Com quantas rêis?

- É, 950 vacas. Vaca parida.

- Vaca parida conta bezerro também?

- É, conta. Cê põe farmácia, farmácia é tudo, né. Quando é farmácia é vaca parida, boi, touro, completa a coisa. O cara fala, a boiada do cara é uma farmácia (risos).

- Tem tudo.

- Tem tudo.

- Saiu da São Carlos almoçou...

- Fazenda Buriti. Põe o ponto do armoço metade da distância.

- Depois dormiu...

- Buriti... é Fazenda Santa Eugênia. O ponto de almoço também, metade da distância.

- Ah, entendi. É uma linha reta?

- É que nem um mapa mesmo, né. Tem hora que pensa que ta vortando pra trás e lá na frente alinha de novo e vai no rumo assim. Agora Fazenda Santa Rosa. Você põe um tracinho no meio. Tracinho no meio, que é o ponto de armoço no meio.

- Mas se você lembrar de cabeça vai para a direita, para a esquerda? Saindo da São Carlos, vai para que lado?

- Pode por assim...

- Fazenda Santa Rosa, aí, é aqui.

- Isso, tem armoço aí no meio. Fazenda Gabinete. Fazenda Capão Verde, eu pulei a Fazenda Del Virgem.

- Agora que vem a Capão Verde? 
- Fazenda São Roque, Fazenda Santa Alaíde, Fazenda Central, Fazenda Rancho Grande, Santa Teresinha. Tudo tem ponto de armoço no meio. Agora é Fazenda Livramento, aí você vira de uma vez de lado, pegando pra cá na região do Rio Negro.

- Aqui é a região do Rio Negro?

- É toda região do Rio Negro, aí a gente atravessa aqui, do São Carlos atravessa o Rio Negro.

- São Carlos já é Rio Negro?

- É bem aqui assim embaixo. Isso, aí você vai costeando nele, deixando para o lado direito e vai subindo ele. Aí você põe Livramento. Aqui na Fazenda Livramento você põe mostrando o rio Negro, pra frente. Aí você continua aí, é Fazenda Juazeiro. Agora Fazenda Loba, Fazenda Campo Eunísio, Fazenda Guaxi, agora Fazenda Santa Rita no final.

- Do outro lado?

- É, Fazenda Santa Rita, região do Rio Negro.

- Tudo Rio Negro aqui? O Rio Negro ta passando aqui pelo lado direito?

- É. Isso, aonde cê desenho aí, nóis atravessa ele na São Carlos, né, no campo da Buriti, sempre margeando ele, perto dele, sempre deixando a direita. Dessa vez agora nós estamos com 15 marcha, mas a média aí 19, 20 dias, é vaca parida, né. Vai forgado, né.

- Eu quero pegar o mapa e fazer o desenho da comitiva que faz. As estradas.

- No mapa tem certinho.

- Não tem as estradas, né?

- Ah, não, não tem as estradas. Essas estrada é estrada boiadeira.

- Eu queria fazer um trabalho só sobre as estradas boisadeiras.

- Aqui vem do Corixão, aí tem a estrada mestra que desce aí, ele vem saí na curva do leque. Tem umas estradas boiadeira que sempre cruza ela pra lá, cruza ela pra cá. Aqui tem o Porto de Santa Luzia que vem do Paiaguás, aí tem uma boiadeira mestra que sai na Barra Mansa, aí tem uma boiadera mestra que tora no meio.

- O que é a boiadeira mestra?

- É a boiadeira central, que fala, né, é aquela que é a rumo reto, né. Ela sai do Porto Santa Luzia e vem bater em Aquidauana, meio rumo reto, assim.

- Mas vocês não pegam ela.

- Nóis cruza ela, né, que ela vem assim, né, ela tora, ela vem do Paiaguás, tora a Nhecolândia, bem dizê no meio, né. E aqui que nem nóis vai, nóis pula ela, né.

- Ah, só cruza.

- Ela vai para Barra Mansa e nóis na Santa Teresinha, nóis pula ela assim. Nóis posa na Santa Teresinha nós cruza ela, quem vem nela, ela cruza assim, né. Nóis pula ela.

- E essas que vocês vão não é uma central?

- Não tem lugar que nem carro num passa, é só estrada boiadeira memo, tem estradinha de trator, mas movimento de carro não tem. Tem uma que é bem movimentada de carro, fica mais pelo meio, né. Ela sai do Rio Negro, que a ponta do aterro que vem do Rio Negro, ela vem até um trecho no Pantanal, aí caba o aterro. Aí ela pega as bitola, né. Aí vem saí aqui na 
Curva do Leque, né. Pra cê pega ela bem, é a estrada mais batida que tem. Pra quem vem de carro pra saí aqui na Curva do Leque, vem por ela. Tem muitas estradas, mas aquela ali é melhor, né. É que o povo, é mais conhecido é mais por ela, porque ela é mais batida, num tem como perdê, né, mas tem muitos que vem passando em fazenda e tal. Só quem não conhece memo, só que quem não conhece já pega a mestra memo, que os portão já é tudo marcado, né, aí vem por ela.

\section{- Essa que vocês vão não é muito batida?}

- Não, essa é mais boiadeira, né. Ah perde, cê vai de fazenda em fazenda, tem lugar memo, que é só batidão de boi memo. Tem batida de trator que as veiz passa, né.

- Mas a comitiva segue muita batida de boi?

- Ah segue, batida de boi. Lugar que passa boi direto fica batidão e tem muita escrita de peão, né.

- Tem escrita? Eu não vi, não achei nenhuma.

- É que o peão escreve assim, em pé de árvore, né.

- E escreve o que?

- É o apelido, põe a data, por exemplo, se você passa hoje aqui, óia que nem tá lá naquela árvore, onde tá aquele couro, o cara lá é colega nosso que escreveu lá. Ele passou ali dia nove do dois de 2009. Então, por exemplo, se eu passar hoje aqui, eu escrevo e dexo a data, e vem outro com boiada lá, pousa aqui, aí já minha escrita, já sabe quantos dias nóis vamo ali na frente. Entendeu? Então pela própria escrita...

- Ainda se fosse na própria árvore, mas é no meio da estrada.

- No batidão tem, cê risca com a ponta da faca. Põe o apelido, põe a data, o dia que passou, a marca da boiada e já sabe até que boiada que vão indo, se é da Nova de Ouro, aí põe a marca da Nove de Ouro, aí já sabe que eles vão com a boiada da marca da Nova de Ouro.

- Ai que legal também.

- Que nem esse patrão nosso, a marca deles é marca WN, fala marca cobrinha né, então põe a marca, põe apelido, data (...) Miranda.

- Você tá na hora tem alguma coisa para fazer ou está tranqüilo?

- Não, estou tranqüilo.

- Então quando a gente saiu daqui foi com o cozinheiro da Nova e Ouro e ele não conhecia o caminho, aí um menino bem novinho que disse estar trabalhando na fazenda ali disse que ia junto para ensinar o caminho. Eu fui nesse dia com o cozinheiro e a gente se perdeu, mas logo na saída tinha um pouco de água... aí a gente dormiu na Buriti...

- Da Buriti vocês foram na Santo Onofre, Santa Filomena, depois para o Japi, parece né?

- Aí eu não fui mais com ele, só esses dias.

- Aí é a rota que vão para ao Paiaguás. Esse runo, Japi, Fazenda Sete de Ouro.

- E é difícil ver estrada na água?

- Quando tem água é difícil, cê vê só o ripão da estrada assim, tem vez que vê, tem veiz que não vê. Quando a água tá limpa cê vê, estrada de trator, de carro, quando a água tá meia suja ocê não enxerga, fica difícil ver. Tem que ser só pelo batidão da boiada memo (risos). 
- Agora quando pega indicação o pessoal fala da cerca...

- Eles fala, quando tá muito cheio, já explica lugar que tá nadano e tal, aí já explica o lugar que tá melhor de passá, tem que ir (...), né.

- Se eu fosse alguém que não conhece o caminho, mas se eu fosse boiadeira, se o senhor fosse falar para mim como ir para São Carlos como falava pra mim?

- Pra indicar?

$-E^{-}$

- É que nem tá aqui, essa estrada aqui é uma estrada muito batida de boi, eu ia falá pra senhora pegá o batidão da boiada. Pegá o batidão de boi, porque pelo batidão de boi aí, aí não tem como errá, né. Agora tem lugar que não passa quase boi e fica mais difícil, né, porque as veiz a estrada já é apagada e num tem batidão de boi. Lugar que passa boi, boi direto é trião assim, esse triero tudo é contínuo né, é diferente de triero de invernada, né, porque triero de invernada é tudo cruzada assim, né. Agora quando é batidão de boi, não, mesmo com essas estradinha apagada assim, os triero de boi tudo, é, é seguindo a estrada, aí cê já vê, tem sinal de escrita nos pé de árvore, tudo que ocê num tem que i (...), né, tem que ir prestando atenção lugar que ocê não conhece, né. A estrada passa aqui, tem um pé de árvore ali, você dá uma oiada, vê se tem escrito de peão. Se tivé escrito de peão, cê tá certo né. Você vai indo aqui, se você vê que tá a estrada apagada, cê num vê escrita de nada, tem que ficá meio veiaca, porque pode acontecer de tá errada, né. Aí já dá uma zebra danada.

- É bom que um ajuda o outro. Você vê essa história da marca acaba ajudando.

- É, e sempre, geralmente esses lugar difícil assim, o peão já marca, já (...) os pé de árvore com faca, já deixa marcado. Se o cozinheiro memo conhece, ele vai na frente, ele já quebra um galho de pau, faz um corte num pé de árvore e aí a turma que vem atrás já vem prestando atenção, né.

- Mas também, a gente que não conhece olha e não enxerga nada.

- E outra também, se ocê vê uma escrita também, não vai nem imaginá que foi um peão que escreveu ali. É, é por isso que você tem que ter malícia, né. Se você vê um pé de árvore com escrita ali, ocê tem que ter malícia que foi um peão de boiadeiro que escreveu. Geralmente, peão de fazenda quase num, quase num escreve em pé de árvore, mais é peão de estrada memo. E o lugar que é batidão de boi, que passa boi direto é difícil cê perder, tem batidão que deixa sinal, onde passa 1000 boi, fica um batidão.

- E muda muito o caminho na cheia e na seca?

- Ah muda, muda que porque diferencia, né. A água estraga muito.

- Aí tem que desviar? Tem lugar que não dá para passar, tem que dar volta?

- É tem lugar que ocê vai beirando o mato, tem veiz, a estrada pega no meio do baixadão, do brejo, aí você tem que ir beirando o mato, béra o mato, tem que ir desviando.

- E quando voltar não pode perder aquela...

- Tem muito, não é todo lugar que dá pra você cruzá na estrada, as veiz memo tando seco, né. Ás vezes a estrada vai assim, aí você vê que a estrada faz um vortão assim. Você não vai andá toda a vida pela estrada sendo que dá para cortar, corta aqui, a boiada vai comendo, tranqüilo, cê sai sai lá na frente, né. Tem que í prestando atenção só no rumo da estrada, né, porque 
talveiz, você pensa que ela vai lá, ela vai pra otro rumo. Então você tem que ir sempre prestando a atenção né. De vez em quando o Ponteiro deixa a turma segurando ali, vai, dá uma vortinha sempre tá cuidando a estrada, o rumo dela, porque senão ela vai aqui, cê tora aqui, de repente ela, tá um pouco ruim, mas cê até cê chega, as veiz o mato vai assim, e se chega lá na frente você num breca lá, cê não tem como cê vortá, aí até ocê vortá com um mundo de boiada aqui, cê pega a estrada de novo, atrasa pra caramba. Então, tem uns lugares num breca, ocê não pode ir metendo as caras, em quarqué lugá. Pouquinho gado não, poquinho gado cê vai, quarqué lugá, lugarzinho apertado, até vará, com 1000 boi aí, já perde hora.

E fala muito, hoje em dia já não tem, mas antigamente que não existia corredor para ir embora para São Paulo, que era tudo cerradão, eles fazia muito dobrada né. Era 7 ou 8 peão na boiada e falava vamos cortar aqui assim, e saí em tal parte e cortava. Cortava aqui e ia saí lá. É dobrada que eles falava. A turma conhecia muito, conhecia, costumado todo ano passá ali, então falava, vamo cortá, saia em tal cabeceira lá, chegava tal hora, meio dia onze hora saia lá. Agora hoje em dia você não pode mais fazê isso porque vai atravessá, chega sai lá numa cerca, já dificulta, você tem mais é que ir pela estrada memo. Abriu um pouquinho assim, já vorta nela, já pega ela de novo, cê arriscá abri dela (...)

- O gado que o senhor leva ele, o senhor falou que leva ele mais quando tá enchendo?

- É quando começa a encher, né, sempre por janeiro, dia 20 de janeiro é a época que está chegando a água, porque a água para chegar aí é rapidão. De uma hora pra outra já é um mar de água. Em janeiro sempre tá movimentando, tá pegando, aí é só uma marcha só, a água feia memo é só uma marcha memo, só o primeiro dia, da São Carlos pra í na Buriti, aí cê atravessou o Rio Negro, o Rio Negro você atravessa ele assim. Atravessou ele, em janeiro já ta nadando já. Tem uma beira ali, que saiu na Buriti já é campo alto já, já pega é campo alto, pega água, vazante, mas não é quem nem o, esse pedacinho da São Carlos pra cê saí no rio aí tem, cê nada, tem uns 3 ou 4 corixo que nada, bolapé. Pegô o rio...

- É mais onde está o rio?

- É, as águas do rio deságua pra cá, o brejão joga água pra cá, saiu dessa aguaceira, pega campo alto e vai.

- E daqui ainda vai mais...

- Pega água do brejo, baia, brejo, vazante, não tem aquele aguaceiro que tem não na São Carlos. Parece que é uma bacia assim, esse trecho parece que é uma bacia, que joga água aqui. Passou São Carlos e Buriti, tudo é arto, aí vai subindo um pouquinho na Nhecolândia aí, Campo Alto já.

- Mas aqui tudo é região do Rio Negro né?

- Aí tudo é rio Negro, cê abriu pra cá assim, já vai por dentro da Nhecolândia.

- Muito obrigada. 
APENDICE D- Marcas dos boiadeiros
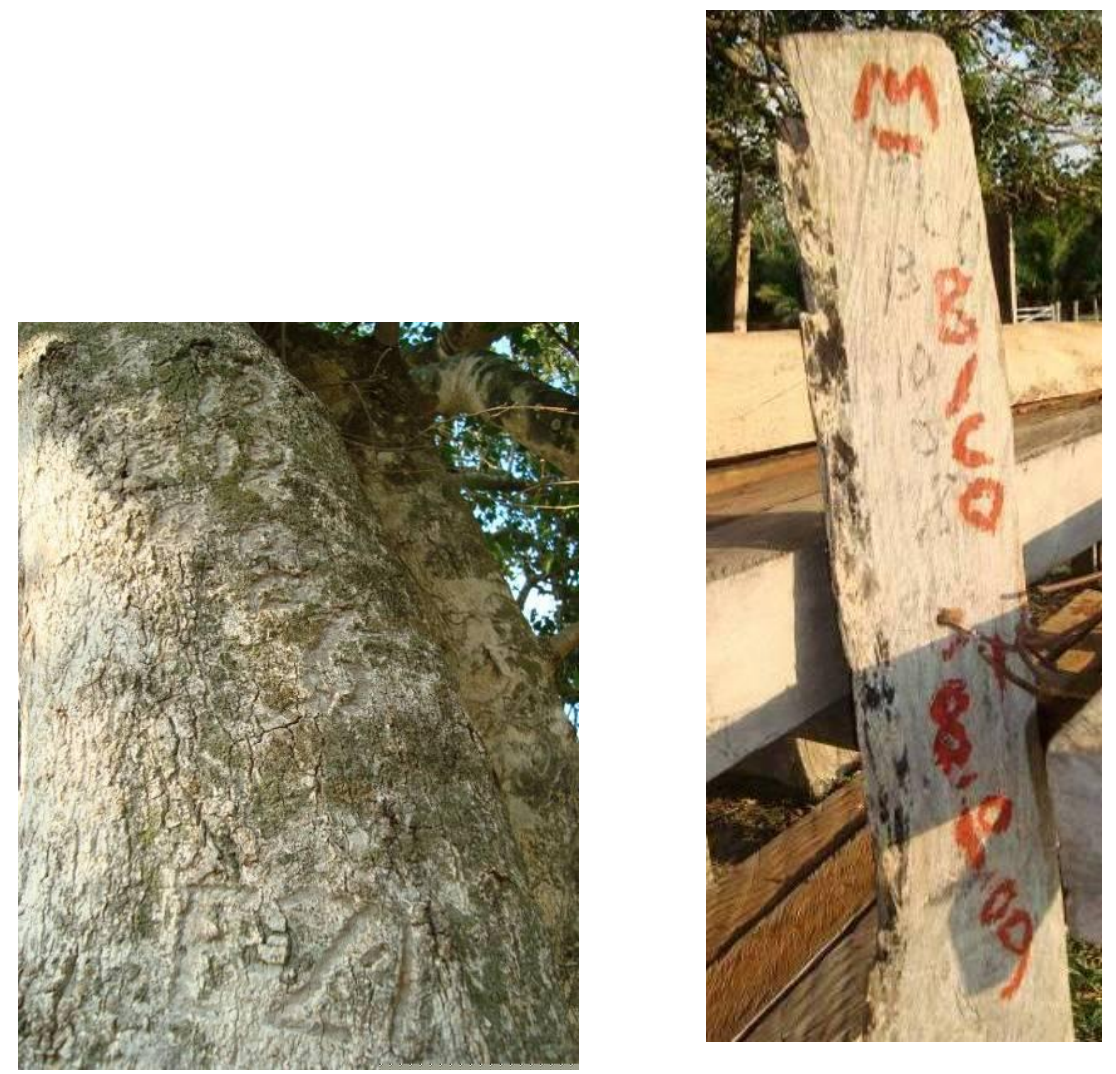





\section{REFERÊNCIA BIBLIOGRÁFICA}

ABDON, M. de M.; SILVA, J. dos S. Delimitação do Pantanal Brasileiro e suas Sub-Regiões. Revista Agropecuária Brasileira, Brasília, v.33, p. 1703-1711, out. 1998. Número especial.

ABRÃO, V. L. S. A pecuária em Corumbá: uma contribuição ao estudo da natureza das relações de produção e de trabalho no Pantanal. 1983. 135f. Dissertação (Mestrado em Geografia) Faculdade de Filosofia, Letras, e Ciências Humanas. Universidade de São Paulo, São Paulo, 1983.

AB' SABER, A. N. Ensaios e entreveros. São Paulo: Edusp/ Imprensa Oficial do Estado de São Paulo, 2004. 522p.

O pantanal mato-grossense e a teoria dos refúgios. Revista Brasileira de Geografia, Rio de Janeiro, v. 50, p. 9-57, 1988. Número especial.

ALHO, C. J. R.; LACHER JUNIOR, T. E.; GONCALVES, H. C. Environmental degradation in the Pantanal ecosystem of Brazil. BioScience, Washington, v. 38, n. 3, p. 164-171, març. 1988.

AGÊNCIA NACIONAL DE ÁGUAS. Resumo Executivo da versão preliminar do Relatório Final do Subprojeto 9.4A - Elaboração do Diagnóstico Analítico do Pantanal e Bacia do Alto Paraguai. In: AGÊNCIA NACIONAL DAS ÁGUA; GLOBAL ENVIRONMENT FACILITY; PROGRAMA DAS NAÇÕES UNIDAS PARA O MEIO AMBIENTE; ORGANIZAÇÃO DOS ESTADOS AMERICANOS. Componente VI - Implementação do Programa de Gerenciamento Integrado do Pantanal e Bacia do Alto Paraguai, do Projeto de Implementação de Práticas de Gerenciamento Integrado de Bacia Hidrográfica para o Pantanal e Bacia do Alto Paraguai. Brasília: ANA/GEF/PNUMA/OEA, 2003, p.01-103.

ADAMOLI, J. Sub- Regiões ou "pantanais" do Pantanal: bacia do Alto Paraguai no Brasil. Brasília: AGÊNCIA NACIONAL DE ÁGUAS, et al., [1982]. Projeto Pantanal Alto Paraguai: mapa. Escala 1: 5.000.000. Disponível em: <http://www.ana.gov.br/gefap/arquivos/Sub_regioes.jpg>. Acesso em: $18 \mathrm{de}$ fev. 2010.

ARCHELA, R. S.; GRATÃO, L.H. B.; TROSTDORF, M. A. S. O lugar dos mapas mentais na representação do lugar. Geografia, Londrina, v. 13, n.1, p.127-141, 2004.

ARRUDA, R. S. V.; DIEGUES, A. C. (Org.). Saberes tradicionais e biodiversidade no Brasil. Brasília: Ministério do Meio Ambiente, 2001. 176p. 
BACHELARD, G. A poética do espaço. Rio de Janeiro: Eldorado Tijuca, 19?-. 177p.

BALÉE, W. Historical ecology: Premises and postulates. In: Advances in historical ecology. New York: Columbia University Press, 1998, p. 13-29.

Footprints of the forest: Ka'apor ethnobotany - The historical ecology of plant utilization by an Amazonian people. New York: Columbia University Press, 1994. 419p.

BANDUCCI JUNIOR, A. Sociedade e natureza no pensamento pantaneiro: representação do mundo sobrenatural entre os peões de fazenda de gado na "Nhecolândia". 1995. 201f. (Corumbá-MS)". Dissertação (Mestrado em Antropologia) - Faculdade de Filosofia, Letras e Ciências Humanas, Universidade de São Paulo, São Paulo, 1995.

BARDIN, L. Análise de Conteúdo. Lisboa: Edições 70, 1995.229p.

BARROS, M. Livro de pré-coisas. Rio de Janeiro: Ed. Civilização brasileira, 1990. 343p.

BERKES, F.; COLDING, J.; FOLKE, C. Rediscovery of traditional ecological knowledge as adaptative management. Ecological applications, Washington, v.10, n5, p.1251-1262, out. 2000 .

BICUDO, M. A. V.; MARTINS, J. A pesquisa qualitativa em psicologia: Fundamentos e recursos básicos. São Paulo: Moraes, 1989. 110p.

BOSI, Alfredo. Cultura Brasileira. $4^{\mathrm{a}}$ ed. São Paulo: Editora Ática, 2003. 224p.

BOSI, Ecléa. Memória e Sociedade: lembrança dos velhos. $6^{\text {a }}$ Ed. São Paulo: Companhia das letras, 1998. 484p.

BRASIL. Constituição (1988). Constituição da República Federativa do Brasil. Brasília, DF: Senado, 1988. Seção 2. Da cultura. art. 216, §v.

BRASIL. Lei n. ${ }^{\circ}$ 9.605, de 12 de fevereiro de 1998. Dispõe sobre as sanções penais e administrativas derivadas de condutas e atividades lesivas ao meio ambiente, e dá outras providências. Diário oficial da União, Brasília, DF, 13 de fev. 1998. Seção 1, § $3^{\circ}$ do art. 29. 
BRASIL. Lei n. ${ }^{\circ}$ 9.985, de 18 de julho de 2000. Regulamenta o art. 225, § $1^{\mathrm{o}}$, incisos I, II, III e VII da Constituição Federal, institui o Sistema Nacional de Unidades de Conservação da Natureza e dá outras providências. Diário oficial da União, Brasília, DF, 19 de jul. 2000. Seção 1, p. 1.

BRASIL. Decreto $\mathrm{n}^{\circ}$ 6.040, de 7 de fevereiro de 2007. Institui a Política Nacional de Desenvolvimento Sustentável dos Povos e Comunidades Tradicionais. Diário oficial da União, Brasília, DF, 08 de fev. 2007, p. 316.

BROWN JUNIOR, K. S. Zoogeografia da região do Pantanal Mato-grossense. In: SIMPÓSIO SOBRE RECURSOS NATURAIS E SÓCIO-ECONÔMICO, 1., 1984, Corumbá. Anais... Brasília: EMBRAPA,1984, p. 137-178.

BRUM, Eliane. A longa viagem dos peões. Revista Época, São Paulo, v. 104, 88-90, maio2000.

CABRERA, A. et al. Etnoecologia Mazateca: Uma Aproximación al Complejo Kosmoscorpus-praxis. Etnoecológica, v.6, n 8-9, p. 61-83, 2001.

CÂMARA, PIERETTI, R. P. Os causeos: uma poética pantaneira. 2007.586f. Tese (Doutorado em Humanidades) - Faculdade de Filosofia e Letras, Universidade Autônoma de Barcelona, Barcelona, 2007.

CAMPOS FILHO, L. V. da S. Tradição e ruptura: subsídios ao planejamento conservacionista direcionado à pecuária e ao turismo, no Pantanal de Poconé - MT. 1998.184f. Dissertação (Mestrado em Ecologia e Conservação da Biodiversidade) Instituto de Biociências, Universidade Federal de Mato-Grosso, Cuiabá, 1998.

CARLSON, P. H. The cowboy way: an exploration of history and culture. Lubbock: Texas Tech University Press, 2000. 238p.

CAVANAGH, J.; MANDER, J. (Edit.). Alternatives to economic globalization: A better world is possible. San Francisco: Berrett -Koehler Publishers, Inc., 2004. 268p.

CLAVAL, P. A geografia cultural: o estado da arte. In: ROSENDAHL, Z.; CORREA, R.L. (Org.). Manifestações da Cultura no Espaço. Rio de Janeiro: Ed. UERJ, 1999, p.59-97. 
O papel da nova geografia cultural na compreensão da ação humana. In: CORRÊA, R.L. e ROSENDAHL, Z. Matrizes da geografia cultural. Rio de Janeiro: Ed. UERJ, 2001, p. 35-86.

COMASTRI, J.A; POTT, A. Introdução e avaliação de forrageiras em "cordilheira" desmatada na sub-região dos Paiaguás, Pantanal Mato-Grossense. Corumbá: EMBRAPA-CPAP, 1996, 47p.

COMITIVA. In: HOLLANDA, A.S.B. Novo dicionário da língua portuguesa. Rio de Janeiro: Nova Fronteira, 1986. 1838p.

CONSERVATION. Pantanal. Disponível em: <http://www. conservation.org.br/onde/pantanal>. Acesso em: 10 set. 2005.

COSTA, M. de F. História de um país inexistente: O Pantanal entre os séculos XVI e XVIII. São Paulo: Kosmos, 1999. 277p.

COSTA, R. H. O mito da desterritorialização: do fim dos territórios à multiterritorialidade. Rio de Janeiro: Bertrand Brasil, 2006. 400p.

CORRÊA FILHO, V. Pantanais Matogrossenses: devastamento e ocupação. Instituto Brasileiro de Geografia e Estatística (IBGE), 1946.170p.

CORRÊA, R.L. Carl Sauer e a escola de Berkley-uma apreciação. In: ROSENDAHL, Z; . Matrizes da geografia cultural (7). Ed. UERJ: Rio de janeiro, 2001, p. 9-34.

DEL RIO, V. e OLIVEIRA, L. (Orgs.). Percepção Ambiental: A experiência brasileira. $2^{\text {a }}$ ed. São Paulo: Studio Nobel, 1999. 266p.

DIEGUES, A. C. O mito moderno da natureza intocada. $3^{\text {a }}$ ed. São Paulo: Hucitec, 1996.169p.

. (Org.). Etnoconservação: novos rumos para a conservação da natureza. São Paulo: Hucitec, 2000. 290p.

DIEGUES JUNIOR, M. Etnias e culturas no Brasil. Rio de Janeiro: Ministério da Educação e Cultura, 1952. 79p. 
Regiões culturais do Brasil. Rio de Janeiro: Centro Brasileiro de Pesquisas Educacionais, Ministério da Educação e Cultura, Instituto Nacional de Estudos Pedagógicos, 1960. 535p.

FERREIRO, E. Psicogênese da Língua Escrita. Porto Alegre: Artes Médicas, 1999. 300p.

FONTANA, A. Ao redor da natureza: investigando a percepção ambiental dos moradores do entorno da estação biológica de Santa Lúcia, Santa Teresa - ES. 2004.169f. Dissertação (Mestrado em Psicologia de Comunidades e Ecologia Social) - Instituto de Psicologia, Universidade Federal do Rio de Janeiro, Rio de Janeiro, 2004.

FREIRE, P. Educação como prática da liberdade. 17 ed. Rio de Janeiro: Paz e Terra, 1979.150p.

FURTADO, F. Invasor ou vizinho? Estudo traz nova visão sobre interação entre porcomonteiro e seus 'primos' do Pantanal. Disponível em: <http://cienciahoje.uol.com.br/controlPanel/materia/view/3835>. Acesso em: 25 set. 2009.

FRUET, L. H. Pantaneiro, um ser em extinção. Revista os Caminhos da Terra, Aquidauana, n. 145, maio, 2004. Disponível em: <http://www2.uol. com. br/ caminhosdaterra/reportagens/145_pantanero.shtml>. Acesso em: 05 set. 2005.

GEERTZ, C. A interpretação das culturas. Rio de Janeiro: LTC. 1989. 213p.

GÓES, Aguinaldo José. As Comitivas, texto. In: Comitiva Boi Soberano. Disponível em: <http://www.comitiva.boisoberano.nom.br/comitivas.html>. Acesso em: 11 set. 2005.

ROSA, G. Grande sertão: Veredas. Rio de Janeiro: Nova Fronteira. 2006. 560p.

HARRIS, M. B. et al. Desafios para proteger o Pantanal brasileiro: ameaças e iniciativas em conservação. Megadiversidade. v.1, n 1, p.156-164, jul. 2005.

INSTITUTO DO PARQUE DO PANTANAL (org.). Atividade Econômica. Disponível em: <http://www.parqueregionaldopantanal.org.br/territorio/economia.php>. Acesso em: 22 abr. 2006.

INSTITUTO BRASILEIRO DE GEOGRAFIA E ESTATÍSTICA. Tipos e aspectos do Brasil. $10^{\mathrm{a}}$ ed. Rio de Janeiro: IBGE, 1975. 508p. 
LEITE, E.F. Marchas na história: comitivas e peões-boiadeiros no Pantanal. Coleção Centro-Oeste de Estudos e Pesquisas. Campo Grande: EdUFMS, 2003. 223p.

LEITE, M. O. F. Homem e ambiente: Um estudo sobre a compreensão de moradores do Vale do Ribeira-SP. 2002. 128f. Graduação (Trabalho de conclusão do curso de Ecologia) - Instituto de Biociências, Universidade Estadual Paulista "Júlio De Mesquita Filho", Rio Claro.

MARQUES, J. G W. O pesquisador e o pesquisado em Etnoecologia: Praticam eles uma Atividade Científica? In: ENCONTRO BAIANO DE ETNOBIOLOGIA E ETNOECOLOGIA, 1., 1999, Feira de Santana. Anais... Feira de Santana: Universidade Estadual de Feira de Santana, 2001, p. 135-141.

O olhar (des) multiplicado. O papel do interdisciplinar e do qualitativo na pesquisa etnobotânica e etnobiológica. In: SEMINÁRIO DE ETNOBIOLOGIA E ETNOECOLOGIA DO SUDESTE, 1., 2001, Rio Claro, Anais... Rio Claro: UNESP/ CNPQ, 2001, p. 31-46.

MATHEWSON, K; SEEMANN, J. A geografia histórico-cultural da Escola de Berkeley: um precursor ao surgimento da História Ambiental. Varia História Belo Horizonte, v. 24, $\mathrm{n}^{\mathrm{o}}$ 39, p.71-85, jan/jun 2008.

MAZZA, M. C. M. et al. Etnobiologia e conservação do bovino pantaneiro. Corumbá: EMBRAPA - CPA/SPI, 1994, p. 1427-1432.

MEDAUAR, O. (Org.). Coletânea de legislação de direito ambiental: Constituição Federal, Ambiental. São Paulo: Revista dos tribunais, 2002.766p.

MEFFE, G.K.; CARROL, C.R. Principles of conservation biology. Sunderland: Sinauder Associates Incorporation, 1994.600p.

MENDONÇA, N. D. O uso dos conceitos: uma questão de interdisciplinaridade. $2^{\mathrm{a}}$ ed. Petrópolis: Editora Vozes, 1983. 176p.

MENESES, U. T. B. de. A paisagem como fato cultural. In: YÁZIGI, E. A., (Org.). Turismo e paisagem. v. (PCD). $\mathrm{n}^{\circ}$ 1, São Paulo : Contexto, 2002, p. 29-64. 
MERLEAU- PONTY, M. Fenomenologia da percepção. Martins Fontes: São Paulo, 1996. $662 \mathrm{p}$.

MOURÃO et al. Embrapa pantanal: 25 anos de pesquisas em prol da conservação do Pantanal. In: SIMPÓSIO SOBRE RECURSOS NATURAIS E SÓCIO-ECONÔMICOS DO PANTANAL: OS DESAFIOS DO NOVO MILÊNIO. 3., 2000, Corumbá, Anais... Corumbá: EMBRAPA, 2000, p.1-55.

NOGUEIRA, A. X. O que é pantanal. São Paulo: Ed. Brasiliense, 1990. 78p.

Pantanal: homem e cultura. Campo Grande: EdUFMS, 2002.155p.

OLIVEIRA, R.C. Teses sobre o indigenismo brasileiro. In: BOSI, A. Cultura Brasileira. $4^{\mathrm{a}}$ ed. São Paulo: Editora Ática, 2003.

OLIVEIRA, C. C. de. Guerreiros do Xarayes. 2004. 153f. Graduação (Trabalho de conclusão do curso de Jornalismo) - Universidade para o Desenvolvimento do Estado e da Região do Pantanal, Campo Grande.

POSEY, D. Indigenous ecological knowledge. In: MANDER, J.; TAULI-CORPUZ, V. (Edit.). Paradigm Wars: Indigenous peoples' resistance to globalization. San Francisco: Sierra Club Books, 2006, p. 29-32.

POTT, A. Ecossistema Pantanal. In: PUIGNOU, J. P. (Edit.). Utilization y manejos de pastizales. Motevideo: IICA-PROCISUR, 1994, p. 31-34.

POTT, A.; VIEIRA, L. M. COMASTRI FILHO, J. A. Portifólio de tecnologias da Embrapa Pantanal: bovinos de corte. Corumbá: EMBRAPA-PANTANAL. 2008, 75p.

PROENÇA, A. C. Pantanal: Gente, tradição e história. $3^{\text {a }}$ ed. Campo Grande: UFMS, 1997. $168 \mathrm{p}$.

QUEIROZ, F. A.; SILVA, L.J. O Sistema Nacional de Unidades de Conservação da Natureza (SNUC) e a Participação Popular: a Lei n. ${ }^{\circ}$ 9985/2000. In: INSTITUTO BRASILEIRO DE ADVOCACIA PÚBLICA. [c.a 2000]. Disponível em:< www.ibap.org/teses2004/teses2004d15.doc>. Acesso em: 03 set. 2009. 
RODELA, L. G.; QUEIROZ NETO, J. P. de, SANTOS, S. A. Classificação das pastagens nativas do Pantanal da Nhecolândia, Mato Grosso do Sul, por meio de imagens de satélite. In: SIMPÓSIO BRASILEIRO DE SENSORIAMENTO REMOTO. 8., 2007, Florianópolis. Anais... Florianópolis: INPE, 2007, p. 4187-4194.

RONDON, J. L. N. Tipos e aspectos do Pantanal. Cuiabá: Livraria Nobel, 1972. 160p.

RONDON, R. Bois e boiadas. In: FERNANDES, F. A. G. Entre histórias e tererés: o ouvir da literatura pantaneira. São Paulo: Editora UNESP, 2002, p. 317-323.

ROSE, D. B. Reports from a wild country: ethics for decolonization. Sidney: UNSW Press, 2004. 256p.

SANDEVILLE JUNIOR, E. Paisagem. Revista paisagem e ambiente, São Paulo, n.20, p. 47-59. 2005. Disponível em: 〈http://www. http://paisagens.arq.br>. Acesso em: 10 set. 2009.

SANTOS, S. A. et al. Guia para estimativa de lotação e pressão de pastejo em pastagens nativas do Pantanal. Corumbá: EMBRAPA - PANTANAL, 2008. 26p.

SAUER, C. O. Foreword to historical geography. In: LEIGHLY, J. (ed.). Land and life: a selection from the writings of Carl Ortwin Sauer. v. 1, $\mathrm{n}^{\circ} 1$. Berkeley: University of California Press, 1983. p. 351-380.

SAUER, C. Desenvolvimentos recentes em geografia cultural. In: CORRÊA, R.L.; ROSENDAHL, Z. Geografia Cultural: um século (1). Rio de Janeiro: EdUERJ, 2000.p. $15-98$.

SAUER, C. The Morfology of Landscape. In: CORRÊA, R.L.; ROSENDAHL, Z. Paisagem, tempo e cultura. EdUERJ: Rio de Janeiro, 1998. p. 12-74.

SILVA, C. J. ; SILVA, J. A. F. No ritmo das águas do Pantanal. NUPAUB/USP, São Paulo: 1995. 210p.

SCHAMA, S. Paisagem e Memória. São Paulo: Companhia das letras, 1996. 696p.

SORIANO, B. M. A. Estação climatológica de Nhumirim, Pantanal- MS. Corumbá: EMBRAPA, 2002. Disponível em: <http://www.cpap.embrapa.br/publicacoes/online/FOL04.pdf >. Acesso em: 04 jul. 2009. 
SOUZA, L. G. Retrospectiva histórica do Pantanal. In: SIMPÓSIO DO PANTANAL SOBRE RECURSOS NATURAIS E SÓCIO ECONÔMICOS. 1., 1984, Corumbá. Anais... Corumbá: EMBRAPA, 1986, p. 199-205.

TERRA das águas. Produção de Rosynei Bigatão, Campo Grande, Focus vídeo, 2006, 1 dvd, (58 min).

TUAN, Y. F. Topofilia: um estudo da percepção, atitudes e valores do meio ambiente. São Paulo: DIFEL, 1980. 288p.

Espaço e lugar: a perspectiva da experiência. São Paulo: DIFEL, 1983. 250p.

What is etnoecology? Origins, scope and implications of a rising discipline. Etnoecológica, México, v.1, nº 1, p. 5-21, 1992.

UNITED NATIONS EDUCATIONAL SCIENTIFIC AND CULTURAL ORGANIZATION. Pantanal. Disponível em: < http://whc.unesco.org/en/list/999>. Acesso em: 17 set. 2009.

Cultural landscape. Disponível em: 〈http://whc.unesco.org/en/culturallandscape〉. Acesso em: 10 set. 2009.

UNIVERSIDADE FEDERAL DO RIO GRANDE DO NORTE. O contexto da Ecologia. Disponível em: 〈www.ecologia.ufrn.br/contexto.htm〉. Acesso em: 12 abr. 2009.

VIANNA, L. P. Considerações críticas sobre a construção da idéia de população tradicional no contexto das Unidades de Conservação. 1996. 207f. Dissertação (Mestrado em Antropologia) - Faculdade de Filosofia, Letras e Ciências Humanas, Universidade de São Paulo, São Paulo, 1996.

VIEIRA, M. L. et al. Profilaxia e Controle do Mal de Cadeiras em Animais Domésticos no Pantanal. Corumbá: EMBRAPA-PANTANAL, 2004. Disponível em: <http://www.cpap.embrapa.br/publicacoes/online/DOC66.pdf>. Acesso em: 20 set. 2009.

VIERTLER, R. B. Métodos de coleta e análise de dados em etnobiologia, etnoecologia e disciplinas correlatas. Rio Claro: UNESP/ CNPQ, 2002. 204p.

WARREN, D. M. Comments on article by Arun Agrawal. Indigenous knowledge and Development Monitor 4 (1). In: NETHERLANDS ORGANIZATION FOR 
INTERNATIONAL COOPERATION IN HIGHER EDUCATION. Disponível em: <http://www. nuffic. nl/ciran/ikdm/articles/agrawal.html> Acesso em: 12 març. 2010.

WERTHEIN, J. Pantaneiros, Cidadãos do Mundo. Disponível em: $<$ http://www.unesco.org.br/noticias/ opiniao/ artigow/2000/ pantaneiros/mostra_documento>. Acesso em: 10 set. 2005.

ZANATTA, B. A. A abordagem cultural na geografia. Disponível em: <http://www.nee.ueg.br/seer/index.php/temporisacao/article/view/28/45>. Acesso em: 12 fev. 2010.

ZIMMERMANN, J. Decreto presidencial reconhece existência formal das populações tradicionais. In: AMBIENTE BRASIL, 2007. Disponível em: <http://noticias.ambientebrasil.com.br/noticia/?id=29432>. Acesso em: 04 set. 2009. 